\title{
Examination of Stainless Steel-Clad Connecticut Yankee Fuel Assembly S004 After Storage in Borated Water
}

September 1982

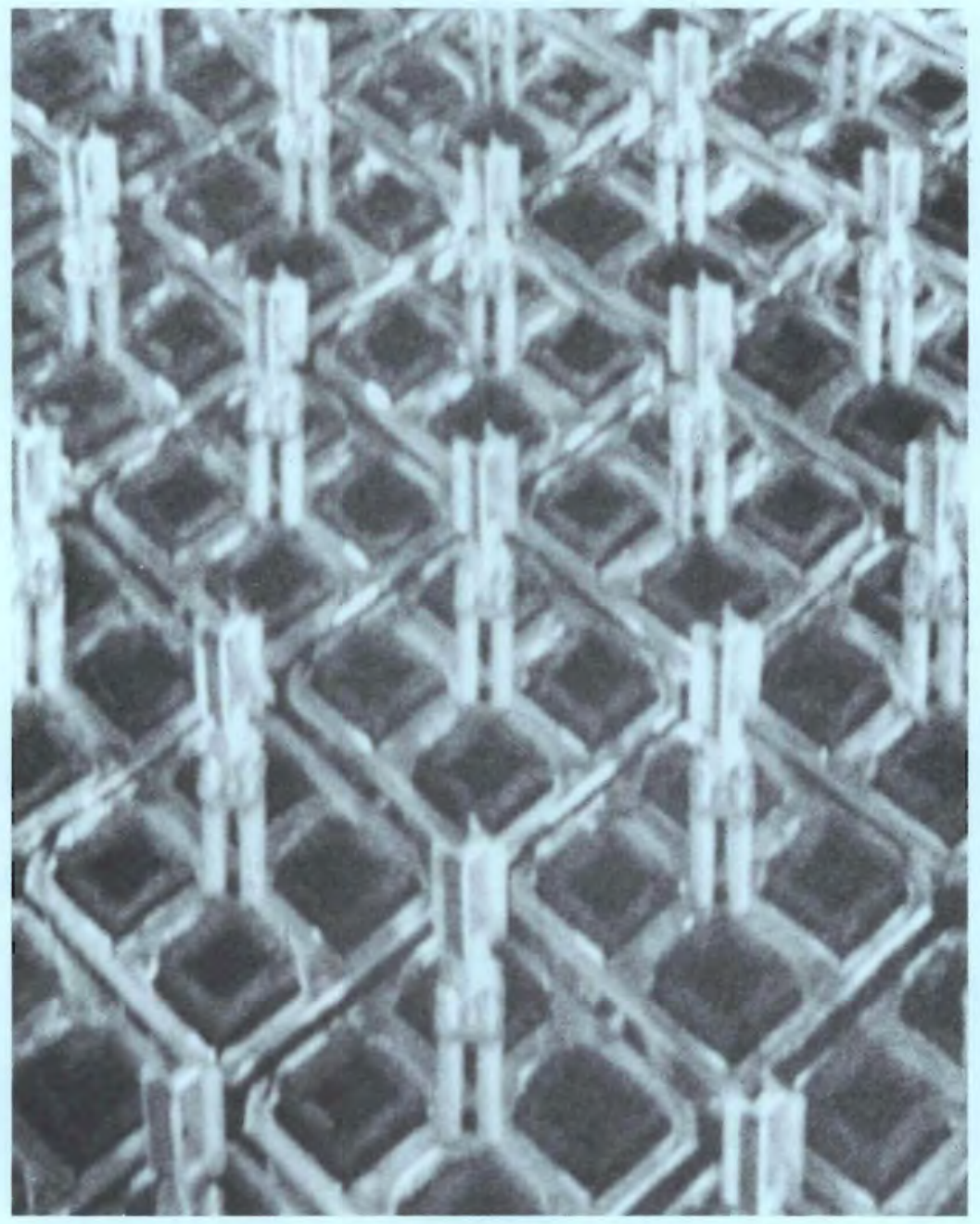

Prepared for the U.S. Department of Energy under Contract DE-AC06-76RLO 1830

Pacific Northwest Laboratory Operated for the U.S. Department of Energy by Battelle Memorial Institute 


\title{
DISCLAIMER
}

This report was prepared as an account of work sponsored by an agency of the United States Government. Neither the United States Government nor any agency thereof, nor any of their employees, makes any warranty, express or implied, or assumes any legal liability or responsibility for the accuracy, completeness, or usefulness of any information, apparatus, product, or process disclosed, or represents that its use would not infringe privately owned rights. Reference herein to any specific commercial product, process, or service by trade name, trademark, manufacturer, or otherwise, does not necessarily constitute or imply its endorsement, recommendation, or favoring by the United States Government or any agency thereof. The views and opinions of authors expressed herein do not necessarily state $\mathrm{cr}$ reflect those of the United States Government or any agency thereof.

\author{
PACIFIC NORTHWEST I.ABORATORY \\ operated by \\ BATTELLE \\ for the \\ UNITED STATES DEPARTMENT OF ENERGY \\ under Contract DE-AC06-76RLO 1830
}

\begin{tabular}{|c|c|}
\hline \multicolumn{2}{|c|}{ Printed in the United States of America } \\
\hline \multicolumn{2}{|c|}{ Available from } \\
\hline \multicolumn{2}{|c|}{ National Technical Information Service } \\
\hline \multirow{2}{*}{\multicolumn{2}{|c|}{$\begin{array}{l}\text { United States Department of Commerce } \\
5285 \text { Port Royal Road }\end{array}$}} \\
\hline & \\
\hline \multicolumn{2}{|c|}{ Springfield, Virginia 22151} \\
\hline \multirow{2}{*}{\multicolumn{2}{|c|}{$\begin{array}{l}\text { NTIS Price Codes } \\
\text { Microfiche A01 }\end{array}$}} \\
\hline & \\
\hline \multicolumn{2}{|c|}{ Printed Copy } \\
\hline & Price \\
\hline Pages & Codes \\
\hline 001-025 & $\mathrm{A} 02$ \\
\hline 026-050 & $\mathrm{A} 03$ \\
\hline 051-075 & A04 \\
\hline 076-100 & A05 \\
\hline $101-125$ & A06 \\
\hline $126-150$ & A07 \\
\hline $151-175$ & A08 \\
\hline $176-200$ & A09 \\
\hline $201-225$ & A010 \\
\hline $226-250$ & A011 \\
\hline $251-275$ & A012 \\
\hline $276-300$ & A013 \\
\hline
\end{tabular}




\section{2}

EXAMINATION OF STAINLESS STEEL-CLAD

CONNECTICUT YANKEE FUEL ASSEMBLY SOO4

AFTER STORAGE IN BORATED WATER

D. C. Langstaff(a)

W. J. Bailey

A. B. Johnson, Jr.

M. P. Landow $(B)$

V. Pasupath $\mathrm{i}(\mathrm{b})$

R. W. Klingensmith(b)

September 1982

Prepared for the U.S. Department of Energy under Contract DE-AC06-76RLO 1830

Pac if ic Northwest Laboratory Richland, Washington 99352

(a) Under subcontract to PNL from Columbia Engineers Services, Inc., and later from TAD Technical Services Corp.

(b) Battelle Columbus Laboratories. 


\section{ACKNOWLEDGMENTS}

Th is document was published under the U.S. Department of Energy's Commercial Spent Fuel Management Program. The contributions from the following individuals are gratefully acknowledged.

M. T. Pitek and R. W. Bishop and Northeast Utilities Service Company arranged the transfer of Connecticut Yankee Qualification Fuel Assembly S004 to this program and supplied background information on the fue 1.

L.F.A. Raven and J. Naylor of British Nuclear Fuels Limited provided background information on Connecticut Yankee Qualification Fuel Assembly S004.

D. M. Rainey of Babcock \& Wilcox Company provided information on calculated fuel rod power and burnup.

T. W. Rees of Superior Tube Company supplied information on fabrication and mechanical properties of the unirradiated cladding.

We especially appreciate the guidance and participation of W. H. Baker of the Savannah River Plant in planning and implementing the program. 


\section{SUMMARY}

Stainless steels are susceptible to stress corrosion cracking in a variety of environments. Investigations have shown, for example, that a few stainless steel pipes at domestic PWR spent fuel pools have developed intergranular stress corrosion cracks at we ld heat-affected zones (Giacobbe 1981). Intergranular stress corrosion cracking was the apparent cause of the failure of stain less steel components in a domestic PWR fuel assembly (NSP 1982). Intergranular corrosion also occurred on some domestic and foreign stainless steelclad gas reactor fuel as a result of sensitization during reactor exposure. These considerations suggest that stainless steel-clad water reactor fuel could be more susceptible to stress-related corrosion than Zircaloy-clad fuel, even though sensitization is not a significant factor during water residence times.

The genera 1 lack of data has pointed out the need for a program to study the corrosion of stainless steel-clad fuel during storage in water. Because the United States has the largest current and potential inventory of stainless steel-clad fuel, $(a)$ it was concluded that examination of stainless steel-clad fuel stored in borated water should be incorporated into the U.S. spent fuel examination programs.

\section{SELECTION OF FUEL FOR EXAMINATION}

A Connecticut Yankee (Haddam Neck) qualification fuel assembly was chosen for examination by Pacific Northwest Laboratory (PNL) under a program sponsored by the U.S. Department of Energy (DOE). Connecticut Yankee is a pressurized water reactor (PWR) that has operated since startup (1967) with stainless stee 1-clad fuel. Spent fuel stored at the reactor pool had characteristics that were attractive to this investigation:

- fuel assemblies characterized before and during irradiation

- relatively high burnups (>30,000 M,Wd/MTU or $>2600 \mathrm{Gj} / \mathrm{kgU}$ )

- substantial storage times ( 5 to $8 \mathrm{yr}$ ) in borated water.

(a) Of the commercial light-water reactor fuel assemblies stored in the United States as of mid-1979, approximately 7\% (nearly 1500 fuel assemblies) contained stainless steel-clad fuel rods. 
Assembly S004 was selected for examination because it had no known reactor-induced defects, had a relatively high burnup $(32,000$ MWd/MTU), had been stored for $5 \mathrm{yr}$, and was a we1l-characterized qualification assembly. At about the same time, hot-cell examinations of two other Connecticut Yankee fuel assemblies, $\mathrm{HO7}$ and G11, were planned under a separate program jointly sponsored by the Northwest Utilities Service Company (NUSCO) and the Electric Power Research Institute (EPRI) to investigate a fuel failure mechanism that occurred during reactor residence. The principal aim of the investigation was to determine the cause of cladding failure in HO7. However, NUSCO and EPRI agreed to provide the DOE program with any evidence regarding the presence or absence of pool-induced effects on the two assemblies. PNL, NUSCO, and EPRI also agreed on the interchange of a few rods between the three assemblies when they are reconstituted prior to shipment from the hot cell for subsequent extended storage.

The selection of these Connecticut Yankee fuel assemblies for the two programs provided a data base on pool storage effects on three related assemblies that contain fuel rods with stainless steel (304L and 304 types) cladding, burnups up to $37,500 \mathrm{MWd} / \mathrm{MTU}$, and a range of pool storage times. The examinations of all three assemblies were conducted at the hot-cell facility at the Battelle Columbus Laboratories.

\section{CLADDING DEGRADATION MECHANISMS ADDRESSED AND INSPECTION METHODS USED}

The S004 fuel examination was designed to address all mechanisms regarded as possible contributors to cladding degradation (see table below).

Mechan ism

Uniform Corrosion

Crud-Localized Corrosion

Stress Corrosion

\section{Pitting}

Corrosion at $\mathrm{Cl}$ adding Defects $(\mathrm{a})$

Fission Product Attack

Corrosion of Weld-Sensitized Areas

Fretting Corrosion
Method of Inspection

Visual Inspection, Metallography
Visual Inspection, Metallography
Visual Inspection, Metallography,
Eddy Current
Visual Inspection, Metallography,
Eddy Current
Visual Inspection, Metallography
Visual Inspection, Metallography
Visual Inspection, Metallography
Visual Inspection, Metallography
(at grid spacer-cladding contact points)

(a) Applicable on ly to assembly HO7. 
At the same time, characteristics of the fuel rods were determined so comparisons could be made with similar data obtained during prior examinations at the reactor pool (see table below), and to establish baseline information in case future examinations of the assembly were considered desirable after additional storage periods.

\begin{tabular}{l} 
Parameter \\
\hline Cladding Mechanical Properties \\
Cladding Ovality \\
Fuel Swelling \\
Fuel Swe 11ing Degradation \\
Grid Spacer Spring Forces \\
Cladd ing Incipient Defects \\
Fuel Rod Weight \\
Fuel Rod Length and Diameter
\end{tabular}

\begin{tabular}{l} 
Measurement \\
\hline Tensile Test, Ring Crush Test \\
Fue1 Rod Profilometry \\
Fue1 Rod Profilometry \\
Visual Inspection, Meta 1lography \\
Measure Fue1 Rod Withdrawa1 Forces \\
Profilometry/Eddy Current \\
Weighing \\
Dimensions/Determinations
\end{tabular}

RESULTS OF NONDESTRUCTIVE AND DESTRUCTIVE EXAMINATIONS

The following conclusions are drawn from nondestructive and destructive examinations of assembly S004:

- Fue 1 rod weight measurements indicated that no significant weight changes had occurred.

- Eddy current measurements showed no strong indications of incipient cladding defects.

- The visual appearance of the fue 1 rods suggested no significant deterioration.

- The results of the metallurgical examination showed that cladding and fuel were typical of irradiated PWR fuel rods. At most locations, oxide layers and crud layers were to thin to be discrenible.

- No significant cladding deterioration was observed in the metallographic examination of the end cap-to-cladding welds and the cladding seam we lds. 
- The results of the mechanical properties testing indicated that the cladding had retained some ductility and did not behave in a brittle manner.

- Visual inspection suggested that the fuel assembly componets (end fittings and rod spacers) had not undergone noticeable degradation. In general, the cladding surface was free of crud and oxide layers, although some localized areas did show surface layers from $1 / 2$ to 6 microns thick. Isolated areas with oxide layers occurred on both the outside and inside surfaces of the cladding. Measurements made from photomicrographs indicated that no detectable change in cladding thickness occurred. This result supported the visual observation of no significant general corrosion. Visual, metallographic, and eddy current examinations failed to reveal any evidence of pitting corrosion or cracking in either the seam-welded cladding or in the end cap-to-cladding we ld areas.

Based on the results, it was concluded that no obvious degradation of the 304L stainless steel-clad spent fuel from assembly S004 occurred during 5 yr of storage in borated water. Furthermore, no obvious degradation due to the pool environment occurred on 304 stainless steel-clad rods in assemblies H07 and G11, which were stored for shorter periods but contained operationally induced cladding defects. The seam welds in the cladding on fuel rods from assembly S004, H07, and G11 were similar in that they showed a wrought microstructure with grains noticeably smaller than those in the cladding base metal. The end cap welds showed a dendritically cored structure, typical of rapidly quenched austenitic weld metal. Some intergranular melting may have occurred in the heat-affected zone (HAZ) in the cladding adjacent to the end cap welds in rods from assemblies $\mathrm{SOO4}$ an H07. However, the weld areas did not show evidence of corrosion-induced degradation. 


\section{CONTENTS}

ACKNOWLEDGMENTS

SUMMARY

INTRODUCION

CONCLUSIONS

FUEL HISTORY AND CHARACTERISTICS

FUEL FABRICATION

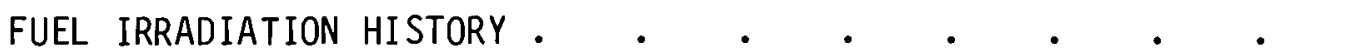

FUEL STORAGE, HANDLING, AND TRANSPORT

FUEL EXAMINATION

FUEL CHARACTERIZATION RESULTS .

NONDESTRUCTIVE EXAMINATIONS OF FUEL ASSEMBLY .

Sipping Test

Visual Examination

NONDESTRUCTIVE EXAMINATIONS OF FUEL RODS

Visual Examination

Rod Weights

Prof $i$ lometry Measurements

Garma Scan

Eddy Current

Temperature

DESTRUCTIVE EXAMINATIONS OF FUEL RODS FROM ASSEMBLY S004

Fission Gas Collection and Analysis

Rod Marking and Sectioning

Fuel Burnup Analysis 


\begin{tabular}{|c|c|c|c|c|c|c|c|c|c|c|c|}
\hline & Fuel Density & - & - & - & - & - & - & - & . & • & 66 \\
\hline & Meta 1 lography & - & - & - & - & - & - & - & - & • & 67 \\
\hline & Ceramography & - & . & - & - & - & - & - & - & • & 99 \\
\hline & Autoradiograph & & - & - & - & - & - & • & - & & 113 \\
\hline & Cladding Mechar & nical & & erties & Testing & - & . & • & . & $\bullet$ & 115 \\
\hline REFERENCES & - & - & - & . & . & - & - & $\bullet$ & . & - & 129 \\
\hline
\end{tabular}




\section{FIGURES}

1 General Outline of Connecticut Yankee qualification

Fue 1 Assembly S004 History: Storage, Transport,

and Examination

2 Schematic Diagram Showing Structural Features of Assembly

S004, Including Details of the Thimble Tube Weld Areas

3 Schematic Diagram of Typical Fuel Rod

from Fuel Assembly S004

$4 \quad$ Fue 1 Rod Loading Diagram for S004

5 Irradiation History of Connecticut Yankee Fuel

Assemblies S004, $\mathrm{HO7}$, and Gll

6 Locations of Fuel Assemblies S004, G11, and H07

in the Connecticut Yankee (Haddam Neck) Core

During Irradiation

7 Change in the Axial Power Profile with Accumulated

Fuel Burnup for a Typical PWR Fuel Assembly . . . . . 15

8 Accumulation of Fuel Burnup with Continued Irradiation

for a Typical PWR Fuel Assembly . $\quad . \quad$. . . . .

9 Variation in the Axial Neutron Flux Profile Along Two

10a Periscope Photographs Illustrating Typical Appearance of

Fuel Rods in Assembly S004 at Connecticut Yankee During

Preshipment Poolside Examination.

10b Small Elliptical Black Spot Observed on Fuel Rod in Assembly SO04 at Connecticut Yankee During Preshipment Poolside

11a Periscope Photograph Illustrating Typical Appearance of

Fuel Rods Including Upper End Caps and Grid Spacer Near

Top Nozzle in Assembly G11 at Connecticut Yankee During

Preshipment Examination

11b Mottled Appearance of Rod Surface Coinciding with Pellet

Interface Locations in Assembly SOO4 at Connecticut

Yankee During Preshipment Examination

12 Convention Used in This Report To Describe Fuel Rod

Locations in the Assembly and Axial Locations of

Spacer Grids and Spans 
13 Specific Destructive Examinations and Specimen

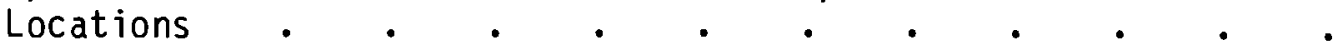

14 Inner Portion of the Top Nozzle Plate of S004

Showing Nozzle Grid, Upper Thimble Tube Welds, and Fuel Rod Upper End Caps.

15a Top View of Top Nozzle . . . . . . . . . . . 32

15b Bottom View of Top Nozzle . . . . . . . . . 33

16 Upper and Lower End Caps and End Cap Weld Areas from S004 Fuel Rods Showing the Machined Area at the Lower End Cap and Handling Marks.

17 Metallography of Longitudinal Section of Lower End Cap Weld from a Stainless Steel-Clad Fuel Rod from $\mathrm{SOO}_{4}$

18 Shallow Indentation on Cladding at Grid Spacer Contact Point That Was Observed During Visual Examination . . . 36

19 Oxide Layer Thickness Trace Similar to the Change in Appearance in the Axial Direction Along S004 Fuel Rod AGR

20 Spiral Profilometry Data for Corner Rods ABG, ACH, AHL, and ADU from Assembly S004 Showing the Envelope of Maximum and Minimum Cladding Diameters Along the Rod Axis

21 Spiral Profilometry Data for Rods $A B G, A H L$, and AHR from Assembly S004 Showing the Envelope of Maximum and Minimum Cladding Diameters and the Mean Cladding Diameter Along the Length of the Rod . . . . . .

22 Overlay of Spiral and Linear Profilometry Traces Showing the Precession of Maximum Ovality Around the Rod Axis

23 Correlation of the Measured ${ }^{137}$ Cs Garma Activities (Normalized) with the Calculated Burnup Values for Fuel Rods R01 and R15 from Assembly S004

24 Gamma Scan Traces Showing Pellet-to-Pellet Interface Locations in Fuel Column of Rod AHL from Assembly SOOA

25 Gamma Scan Traces from Five Fuel Rods from Assembly S004 Showing the Pellet-to-Pellet Interfaces Distinctly in the Lower Power Rods and Less Distinctly in the Higher Power Rods 
27 Gamma Scan Traces for Selected Fuel Rods from Assemblies G11 and HO7 Showing the Pellet-to-Pellet Interfaces Distinctly

in (b) G11 Rod 595AO1 and (c) HO7 Rod 217EO2 and Less

Distinctly in (a) G11 Rod 595A10 . . . . . . . .

28 Eddy Current Traces of Rod AHR from Assembly SO04 Showing

Typical Traces and the Area Suspected to Contain a

29 Schematic Diagram of the Fission Gas Collection

System Used at the Hot-Cell Facility at Battelle

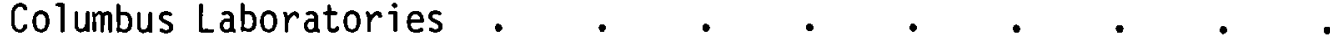

30 Metallography of Archive 304L Stainless Steel Cladding

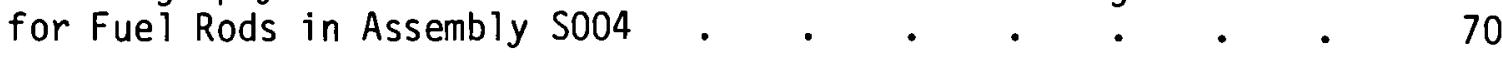

31 Metallography of Cladding from S004 Fuel Rod ABG,

56.75 in. (144 cm) Above Rod Bottom . . . . .

32 Metallography of Cladding from Connecticut Yankee

Fue 1 Rods

33 Metallography Showing the Heat-Affected Zone of End Cap Weld

34 Metallography of Weld Heat-Affected Zone (HAZ) from

the Lower End Cap, Fuel Rod AHR, Assembly SO04 . . . . . 74

35 Metallography of Surface Condition of Fuel Rods from

Connecticut Yankee Fuel Assemblies G11 and H07 . . . .

36 Metallography of Weld Area of Upper End Cap from S004

Fuel Rod ABG . . . . . . . . . .

37 Metal lography of Cladding Adjacent to Lower End Cap Welds

from Connecticut Yankee Fuel Rods . . . . .

38 Typical As-Polished Transverse Sections of Cladding and and Fuel from Rod AHR Showing the Clean Cladding Interior and Exterior Surfaces, i.e., Free of Measurable Crud or Oxide (or Other Reaction) Layers . . . . . . .

39 Typical As-Polished Transverse Sections of Cladding and Fuel from Rod AHR Showing the Clean Cladding Interior and Exterior Surfaces, i.e., Free of Measurable Crud or Oxide (or Other Reaction) Layers . . . . . . .

40 Typical As-Polished Transverse Sections of Cladding and Fuel from Rod AHR Showing the Clean Cladding Interior and Exterior Surfaces, i.e., Free of Measurable Crud or Oxide (or Other Reaction) Layers 
41 Typical As-Polished Transverse Metallographic Sections of Cladding and Fuel from Rod ABG Showing the Essentially Clean Cladding Interior and Exterior Surfaces, i.e., Free of Crud or Oxide Layers

42 As-Polished Transverse Metallographic Section from Fuel Rod AHR from Assembly SOO4 Showing Axial Scratches . . . . . . 82

43 Metallography of ID or OD Surface Condition of Cladding from Connecticut Yankee Fuel Rods

44 Surface Condition of Cladding OD from SOO4 Fuel Rod ABG at $41.50 \mathrm{in}$. $(105 \mathrm{~cm})$ Above the Bottom of the Rod . . . .

45 Metallography of Grid Spacer Dimple on Cladding OD from SOO4 Fuel Rod AHR

46 Metallography of ID and OD Surface Condition of Cladding from Connecticut Yankee Fuel Rods Near the Lower End Cap . .

47 Metallography of Cladding Surface Condition Near Lower End Cap on SOO4 Fuel Rod AHR . $\quad . \quad$. $\quad . \quad$. 87

48 Metallography of Surface Layer on Cladding

49 Metallography of Surface Layers at $270^{\circ}$ Near the Lower End Cap on the Cladding from Fuel Rod ABG from Assembly S004

50 Surface Appearance of Lower End Cap Area of Fuel Rod ABG from Assembly S004

51 Surface Condition of Cladding from Connecticut Yankee Fuel Rod 217E02 from Assembly $\mathrm{H} 07$ Including the

Detail of Modified Structure on the Cladding ID .

52 Metallography of Weld Area and Base Metal Near Lower

End Cap Weld Areas of Fuel Rods (a) AHR from

Assembly SOO4 and (b) $217 \mathrm{EO} 2$ from Assembly H07

53 Metallography of Weld Metal from End Cap Welds

from Connecticut Yankee Fuel Rods

54 As-Polished Macrograph of Rod AHR at 36.50 in. (93 cm) from Bottom End

55 As-Polished Macrograph of Rod AHR at 56.75 in. (144 cm) from Bottom End

56 As-Polished Macrograph of Rod AHR at $80.50 \mathrm{in} .(204 \mathrm{~cm})$ 
57 As-Polished Macrograph of Rod AHR at 83.75 in. $(213 \mathrm{~cm})$

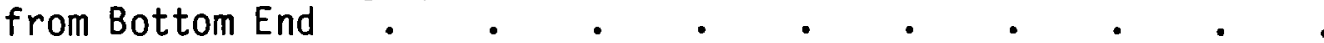

58 As-Polished Macrograph of Rod AHR at 98.25 in. $(250 \mathrm{~cm})$

59 As-Polished Macrograph of Rod ABG at 41.50 in. (105 cm)

60 As-Pol ished Macrograph of Rod ABG at 56.75 in. (144 cm)

61 Radial Strip of an Etched Transverse Metallographic Section from Low-Power Fuel Rod ABG from Assembly S004 at 56.75 in. $(144 \mathrm{~cm})$ Above the Bottom of the Rod Showing the Fuel Microstructure Typical of the High-Power Region.

62 Radial Strip of an Etched Transverse Metallographic Section from High-Power Fuel Rod AHR from S004 at 56.75 in. $(144 \mathrm{~cm})$ Above the Bottom of the Rod Showing the Fuel Microstructure Typical of the High-Power Region . . . . . .

63 Macrograph of an Etched Transverse Metal lographic Section from Rod AHR from Assembly S004 at $56.75 \mathrm{in} .(144 \mathrm{~cm})$ Above the Bottom of the Rod Showing the Locations on Photo Composite

Strips of the Fuel

64 Photo Composite of (a) Area \#1 (b) Area \#2, (c) Area \#3, (d) Area \#4 from Figure 63 Showing Details of the Fuel Microstructure

65 Photomicrograph Showing Grain Size Discontinuity Across a Crack Interface from the Area \#3 Location

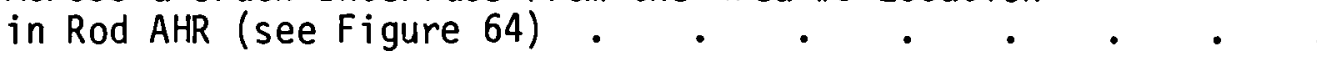

Photomicrograph of Etched Fuel Showing Range of Grain Sizes Between (a) Rod ABG and (b) Rod AHR . . . . .

67 Alpha Autoradiograph from Rod AHR at $56.75 \mathrm{in.}(144 \mathrm{~cm}$ ) Above the Bottom of the Rod Showing the Increase of Alpha Emitter Concentration Over a Very Short Distance

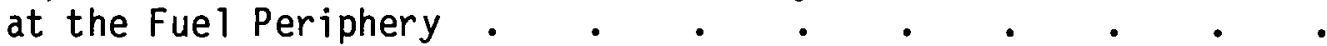

Beta-Gamma Autoradiograph from Rod AHR at $56.75 \mathrm{in} .(144 \mathrm{~cm}$ ) Above the Bottom of the Rod Showing a Steep Increase in Beta-Gamma Emitter Concentration at the Fue 1 Periphery, Along Cracks and at Some Voids 
69 Macrograph of the As-Polished Surface from Rod AHR at $56.75 \mathrm{in} .(144 \mathrm{~cm})$ Above the Bottom of the Rod Showing the Structure of the Fuel Seen in the Autoradiographs

in Figures 67 and 68 . $\quad . \quad . \quad . \quad . \quad .$.

70 Results of Side-Pressing Crush Tests of Rings of Irradiated 304L Stainless Steel Cladding Showing the Dependence of Collapse Load on Deformation Rate

$71 \quad$ Collapse Deformation Versus Deformation Rate from Ring Crush Tests on Irradiated 304L Stainless Steel Showing the Dependence of Deformation at Collapse on

Deformation Rate

72 Schematic Load Versus Displacement Curve for Side-Pressing Ring Crush Test

73 Dependence of Collapse Load on Ring Geometry in the Side-Pressing Ring Crush Test . .

$74 \quad$ Cladding Tensile Test Results for Irradiated 304L

Stainless Steel Showing the Low Strain-Rate

Stainless Steel Showing

75 Cladding Tensile Test Results Showing the Strain-Rate Dependence of the Difference Between the Ultimate Tensile and Yield Strengths for Irradiated 304L Stainless Steel

76 Cladding Tensile Test Results Showing the Dependence of Strain-Rate on the Specimen Uniform Elongation for Irradiated $304 \mathrm{~L}$ Stainless Stee 
TABLES

1 Fabrication Data for Connecticut Yankee (Haddam Neck) Qual ification Fuel Assembly SO04 .

2 Fabrication of Seam-Welded, Stainless Steel Cladding for Fuel Rods

3 Irradiation and Storage Histories for Connecticut Yankee Fuel Assemblies S004, G11, and H07 . . . . . . . 13

4 Connecticut Yankee (Haddam Neck) Operating Information During Cycles 3,4 , and 5 . . . . . . . . 13

5 Summary of Nominal Environmental Conditions Encountered by Fuel Assembly S004 Through November 1980 .

6 Examination History of $\mathrm{S} 004$. . . . . . . . . 18

7 Characterization of Selected S004 Fuel Rods in the As-Fabricated Condition at BNFL . . . . .

$8 \quad$ Fuel Rod Length Measurements for Fuel Assembly S004 After One Cycle of Irradiation . . . . . . . 20

9 Results of Visual Examination of Assembly SOO4 by Underwater Periscope . $. \quad . \quad . \quad . \quad . \quad . \quad .$.

10 Summary of Nondestructive Examinations Completed on Fuel Rods Removed from Fuel Assembly S004 . . . . 27

11 Spent Fuel Destructive Examination Plan . . . . . 28

12 Results from Wet Sipping Test of Shipping Cask at BCL Before Assembly SO04 Was Removed. . . . . . 30

13 Fuel Rod Weight Data for Assembly S004 . . . . . . 38

14 Fuel Rod Weight Statistics for Assembly SO04 . . . . . 39

15 Cesium-137 Gamma Scan Measurements for Selected Fuel Rods from Assembly SOO4 . . . . . . . .

16 Temperature Measurements for Cladding on Irradiated Fuel Rods from S004 . . . . . . . . . . . 53

17 Measurements for Gases Collected from Connecticut Yankee Fue 1 Rods 
18 Compositions of Collected Gases and Calculated Fue 1 Burnups for Selected Connecticut Yankee Fuel Rods . . . 57

19 Gas Pressures in Connecticut Yankee Fuel Rods . . . . 59

20 Fission Gas Release in Selected Connecticut Yankee

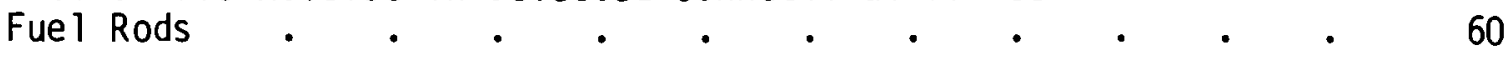

21 Moles of $(\mathrm{Xe}+\mathrm{Kr})$ and $\mathrm{H}_{2}$ in Selected Connecticut

Yankee Fuel Rods . • . • . • . . . . 61

22 Sectioning for Fuel Rod AHR from Assembly S004 . . . . 64

23 Sectioning for Fuel Rod ABG from Assembly S004 . . . . 66

24 Mass Spectrometric Analysis of Fuel Burnup Sample AHR-8 . . 66

25 Measured Fuel Densities for Rod AHR from Assembly S004 . . 67

26 Information on the Metallographic Examination of Fuel Rods from Connecticut Yankee Fuel Assemblies S004, H07 and G11. . 89

27 S004 Cladding Thickness Measurements . • • • • • 96

28 Side-Pressing Ring Crush Test Results . . • • . • 121

29 Normalized Collapse Loads for Ring Crush Tests
of Cladding from S004 Rod AHR . . . . . . . . 125

30 Tensile Test Results . . . . . . . . . . . 126 


\section{INTRODUCTION}

Storage of spent nuclear fuel in water has been and will continue to be an important factor in nuclear fuel management. Currently, water storage of spent nuclear fuel is the only licensed option in the United States. The last cormercial reprocessing of spent fuel occurred in 1971. Since then, the commercial spent fuel inventory stored in U.S. water pools has $r$ isen to about 28,000 fuel assemblies (Carter 1980). Another option, dry storage, is also being investigated as an inter im fuel management measure (Anderson and Meyer 1980; Johnson, Gilbert, and Guenther 1982). However, even with that option, spent fuel will continue to be discharged to water storage for a cooling period before being transferred to dry storage.

Spent fuel examinations conducted in Canada, the Federal Republic of Germany, and the United Kingdom have investigated the possible effects of water storage. Only one stainless steel-clad fuel rod has been examined in those programs. Although there has been no evidence of degradation in stainless steel-clad water reactor fuel stored for over a decade in water, there have been a few cases of stress corrosion cracking of stainless steel: 1) intergranular stress-corrosion cracks developed in the weld heat-affected zones of sta in less steel pipes at domestic PWR spent fuel pools (Giacobbe 1981);

2) intergranular stress corrosion cracking was the apparent cause of failure of stainless steel components in one domestic PWR fuel assembly (NSP 1982); and 3) some stainless steel-clad gas reactor fuel underwent intergranular corrosion as a result of sensitization during the reactor exposure.

Because the U.S. has the largest current and potential inventory of stainless steel-clad water reactor fuel, the Department of Energy (DOE) has included the examination of such fuel in the Spent Fuel and Fuel Pool Component Integrity Program, which DOE has implemented to establish the corrosion and metallurgical condition of spent light-water reactor (LWR) fuel assemblies after extended storage in water. The program was designed to provide insight into fuel behavior of value in licensing and operating spent fuel storage pools. As part of that program, Pacific Northwest Laboratory (PNL) has examined the 
Connecticut Yankee qualifiation fuel assmbly S004 with the objective of establishing its condition after $5 \mathrm{yr}$ of storage in borated water. The S004 assembly contains stainless steel-clad fuel rods, 20 of which were well characterized prior to irradiation. The incentives for investigation such a fuel assembly were: 1) of the nuclear fuel stored in the United States as of mid-1979, approximately 7\%, nearly 1500 fuel assemblies, contained stainless stee 1-clad fuel (Johnson 1980); and 2) stainless steel is known to show susceptibility to stress-corrosion cracking in some environments and in certain metallurgical conditions. Some standard commercial fuel assemblies stored at the Connecticut Yankes spent fuel pool had higher burnups (i.e., irradiation exposures to $36,800 \mathrm{MWd} / \mathrm{MTU}$ or $3180 \mathrm{GJ} / \mathrm{kgU}$ ) or longer times (to $10 \mathrm{yr}$ versus 5 yr for S004) in pool storage. However, fuel rods in those assemblies were not characterized as we 11 as some in S004. As of 1979, the highest burnups for fuel assemblies with stainless steel-clad fuel rods discharged from domestic and foreign commercial reactors were $37,500 \mathrm{MWd} / \mathrm{MTU}(3,240 \mathrm{GJ} / \mathrm{kgU}$ ) (batch average) and $32,000 \mathrm{MWd} / \mathrm{MTU}(3,765 \mathrm{GJ} / \mathrm{kgU})$, respectively (Johnson 1980). Some domestic fuel with batch average burnups to the former level were discharged during this 1972-1976 period.

Another objective of the PNL examination was to characterize the fuel to the extent that any significant changes in the assembly condition caused by subsequent extended pool storage would be discernible if future assembly examinations are conducted. Figure 1 provides an overall perspective of the general plan that was developed prior to the examinations. All examinations were made at the Battelle Columbus Laboratories (BCL) Nuclear Materials Technology Facility.

In a complementary program (Pasupath $i$ and Klingensmith 1981), the Northeast Utilities Service Company (NUSCO) and the Electric Power Research Institute (EPRI) examined Connecticut Yankee fuel assemblies to determine the cause of reactor-induced fuel rod failures that had occurred in 36 of 48 Batch-8 fuel assemblies. One Batch-8 fuel assembly (H07) and one Batch-7 fuel assembly (G11) have been examined (Figure 1). Assembly H07 had several fuel rods that failed during operation in the reactor. Fuel rods in Assembly Gll did not fail during operation in the reactor. Fuel pellets for $\mathrm{H} 07$ and SOO4 were fabricated by the same fuel supplier, British Nuclear Fuels Limited 


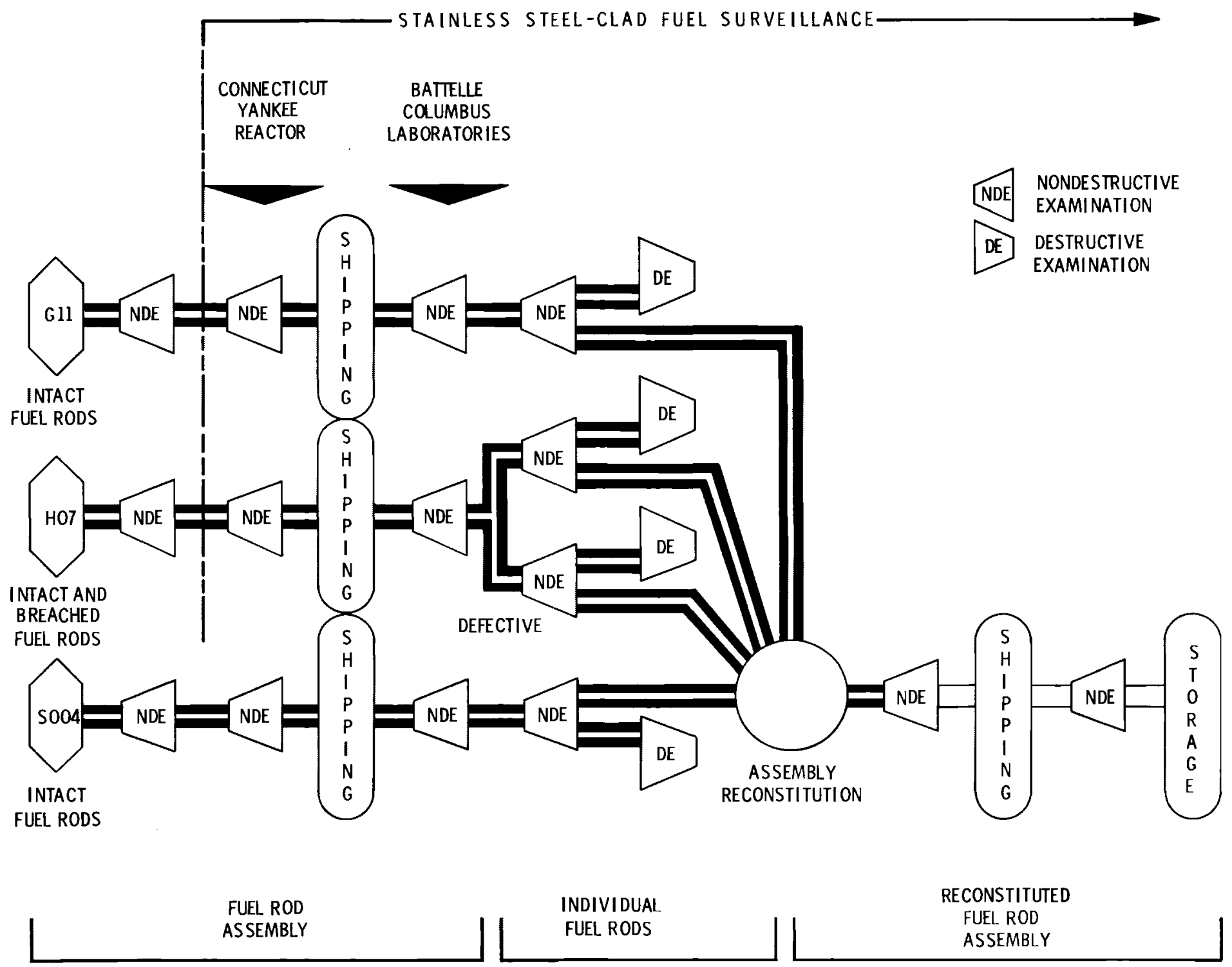

FIGURE 1. General Outline of Connecticut Yankee Qualification Fuel Assembly SO04 History: Storage, Transport, and Examination 
(BNFL). The examinations of assemblies $\mathrm{G} 11$ and $\mathrm{H} 07$ were conducted concurrently but independently of the examination of assembly S004 at BCL. However, the concurrent examinations provided an opportunity to select a few G11 and HO7 fuel rods for insertion into assembly 5004 when it is reconstituted prior to shipment from the hot cell for subsequent extended storage.

As noted in the report from the NUSCO/EPRI program (Pasupathi and Klingensmith 1981), there have been several other documented cases of failures of stainless steel-clad fuel. The Connecticut Yankee fuel rod failures were similar to those in the Vulca in core of the BR-3 reactor (Storen and Locke 1970), and were probably similar to the failures observed in SENA (Multer 1975).

The postirradiation examination of S004 was initiated at BCL in July 1980. This report contains PNL's results from both nondestructive and destructive examinations of assembly $\mathrm{SOO4}$ and relevant results from assemblies H07 and G11. Also included in a brief history of the fuel assembly fabrication, storage, and transport. 


\section{CONCLUSIONS}

The studies of the corrosion and metallurgical condition of pool-stored S004, H07, and G11 fuel rods from the Connecticut Yankee (Haddam Neck) Reactor resulted in the following conclusions:

- No obvious degradation of the 304L stainless steel-clad fuel rods from assembly S004 occurred after 5 yr of storage in borated water. With respect to crud and corrosion, the fuel rods from assembly 5004 were very similar to 304 stainless steel-clad fuel rods from assemblies $\mathrm{HO7}$ and G11, which had been stored for much shorter periods (1.3 and $2.6 \mathrm{yr}$, respectively).

- Fuel rods from assemblies S004, H07, and G11 were relatively free of crud and oxide films.

- In contrast to the cases with $\mathrm{HO7}$ and G11 rods, no pellet chips were lodged in the fuel-cladding gaps of S004 rods. Pellet chips in 5004 rods were also much smaller than those found in H07 and G11 rods.

- No cladding breaches, with concomitant loss of fission products and/or fuel, or ingress of coolant occurred in the precharacterized fuel rods examined during postirradiation examination based on: reactor operating data (NRC Docket Reports) sipping test results rod weight measurements eddy current measurements.

- Cladding and weld metallography is very similar for the S004, H07, and G11 fuel rods that were examined.

- Cladding cracks, pitting, or significant general corrosion were not evident from the metallographic examination of the cladding from SO04 fuel rods on either the OD or ID of the cladding.

- Cracks, pitting, or significant general corrosion were not evident in cladding or end cap weld areas on fuel rods from assemblies S004, $\mathrm{HO7}$, and G11. 
- A qualitative indication of good ductility was evident in the ring crush test of $\mathrm{SOO} 4$ fuel rod AHR irradiated cladding.

- Irradiation strengthening, with a concomitant reduction of ductility, was observed in cladding from fuel rod AHR, assuming the unirradiated strength and ductility were similar to those of the 304SS archive cladding used on fuel rods in the HOT assembly.

- The mechanical properties of the irradiated cladding are deformation rate dependent.

- There are at least two operating temperature regimes (i.e., some fuel rods operated with higher centerl ine fuel temperatures than others) represented in the fuel rods from the S004 fuel assembly, based on fission gas release (order of magnitude difference noted) and fuel microstructural information from the fuel rods that were destructively examined. 


\section{FUEL HISTORY AND CHARACTERISTICS}

The qualification fuel assembly S004 was irradiated in the Connecticut Yankee (Haddam Neck) reactor, a Westinghouse-designed pressurized water reactor (PWR), operated by the Connecticut Yankee Atomic Power Company and partially owned by the Northeast Utilities Services Company (NUSCO). Commercial operation began in June 1967, with power levels of 575 MWe (1825 MWt). Assembly S004 was supplied to the reactor by Gulf General Atomic (GGA). The assembly was irradiated in the reactor core during cycles 3, 4, and 5 and was stored in the Connecticut Yankee spent fuel pool for $5 \mathrm{yr}$ after it was discharged from the reactor. In May 1980, it was shipped to the Battelle Columbus Laboratories Nuclear Materials Technology Facility at West Jefferson, Ohio, for hot-cell examination.

\section{FUEL FABRICATION}

Gulf General Atomic contracted with British Nuclear Fuels Limited (BNFL) to design and fabricate the fuel assembly. The fuel rods contained $\mathrm{UO}_{2}$ pellets enriched to $4.0 \%{ }^{235} U$ by weight in $10.76-\mathrm{mm}(0.4235-\mathrm{in}$.$) 0D, seam-welded$ and drawn Type $304 \mathrm{~L}$ stainless steel cladding, $(\mathrm{a})$ with a $0.42-\mathrm{mm}(0.0165-\mathrm{in}$. wall thickness. The fuel rod length was $3.2171 \mathrm{~m}$ (126.66 in.). The fill gas composition was typically 96 to $98 \%$ helium and 2 to $4 \%$ air with about 25 to $30 \mathrm{ppm}{ }^{85} \mathrm{Kr}$, based on results from destructive tests on sample rods; the fill gas pressure was $1 \mathrm{~atm}$. The control rod guide tubes and the instrument tube were fabricated from 12.2-mm (0.480-in.) 00, Type 304L stainless steel tubing witha 0.34-mm (0.0135-in.) wall thickness. The grid spacers and springs were fabricated from Inconel 718. The upper and lower nozzles were made from Type 321 stainless steel. The upper nozzle was not designed to be readily removable. Additional design details are listed in Table 1.

(a) BNFL had specified Type 304 stainless steel for the fuel cladding. However, the results of PNL's analys is of the certified archive sample of the fuel cladding supplied by BNFL showed a carbon content of $0.030 \%$. The maximum carbon content is $0.08 \%$ and $0.03 \%$ for Types 304 and $304 \mathrm{~L}$ stainless steel, respectively. For this reason, the fuel cladding is labeled Type $304 \mathrm{~L}$ in this report. 


\section{TABLE 1. Fabrication Data for Connecticut Yankee (Haddam Neck)}

Qualification Fuel Assembly S004

Fuel Vendor

Fuel Designer and Fabricator

Type (Rod Array)

Control Rod Guide Tubes:

Number

Upper OD

Wall Thickness

Material

Instrument Tubes:

Number

OD

Wall Thickness

Material

Spacer Grids:

Number

Material

Spring Material

Fuel Rods (not prepressurized):

Number

Length

OD

Wall Thickness

Material

Fuel Pellet Stack Length

Diametral Gap(b)

Orifice Plate Material

Plenum Springs:

Working Length

Material

Fuel Pellet:

Geometry

Diameter

Material

Enrichment

Mean Density

Mean Weight/Rod

Length
Gulf General Atomic

British Nuclear Fuels Limited

$15 \times 15$

20

$12.2 \mathrm{~mm}(0.480$ in. $)$

$0.34 \mathrm{~mm}(0.0135$ in.)

304L Stain less Steel

1

$12.2 \mathrm{~mm}(0.480$ in. $)$

$0.34 \mathrm{~mm}(0.0135$ in. $)$

304L Stainless Steel

7

Incone 718

Inconel 718

204

$3.2171 \mathrm{~mm}$ (126.66 in.)

$10.76 \mathrm{~mm}(0.4235$ in.)

$0.42 \mathrm{~mm}(0.0165$ in.)

304L Stainless Steel (a)

3.0798-3.0925 m (121.25-121.75 in.)

$0.18 \mathrm{~mm}$ ( 0.007 in.)

321 Stainless Steel

$102 \mathrm{~mm}$ (4.06 in.)

302 Stainless Steel

Solid Right Circular

Cylinder with Dished Ends

9.73-9.75 mm (0.383-0.384 in.)

$\mathrm{UO}_{2}$

4.00 wt\% $235 \mathrm{U}$

$10.215 \mathrm{~g} / \mathrm{cm}^{3}(93.20 \%$ TD) (c)

$2.264 \mathrm{~kg}(4.987 \mathrm{lb})$

$11.4 \mathrm{~mm}(0.450$ in. $)$

(a) See Footnote (a) under "FUEL FABRICATION."

(b) Diametral gap is cladding inside diameter minus pellet diameter.

(c) Theoretical density (TD) for stoichiometric $U_{2}$ is $10.96 \mathrm{~g} / \mathrm{cm}^{3}$.

The assembly, a $15 \times 15$ rod array shown schematically in Figure 2, contains 1 instrument tube, 20 control rod guide tubes, and 204 fuel rods. Figure 3 is a schematic drawing of a typical fuel rod in this assembly. 


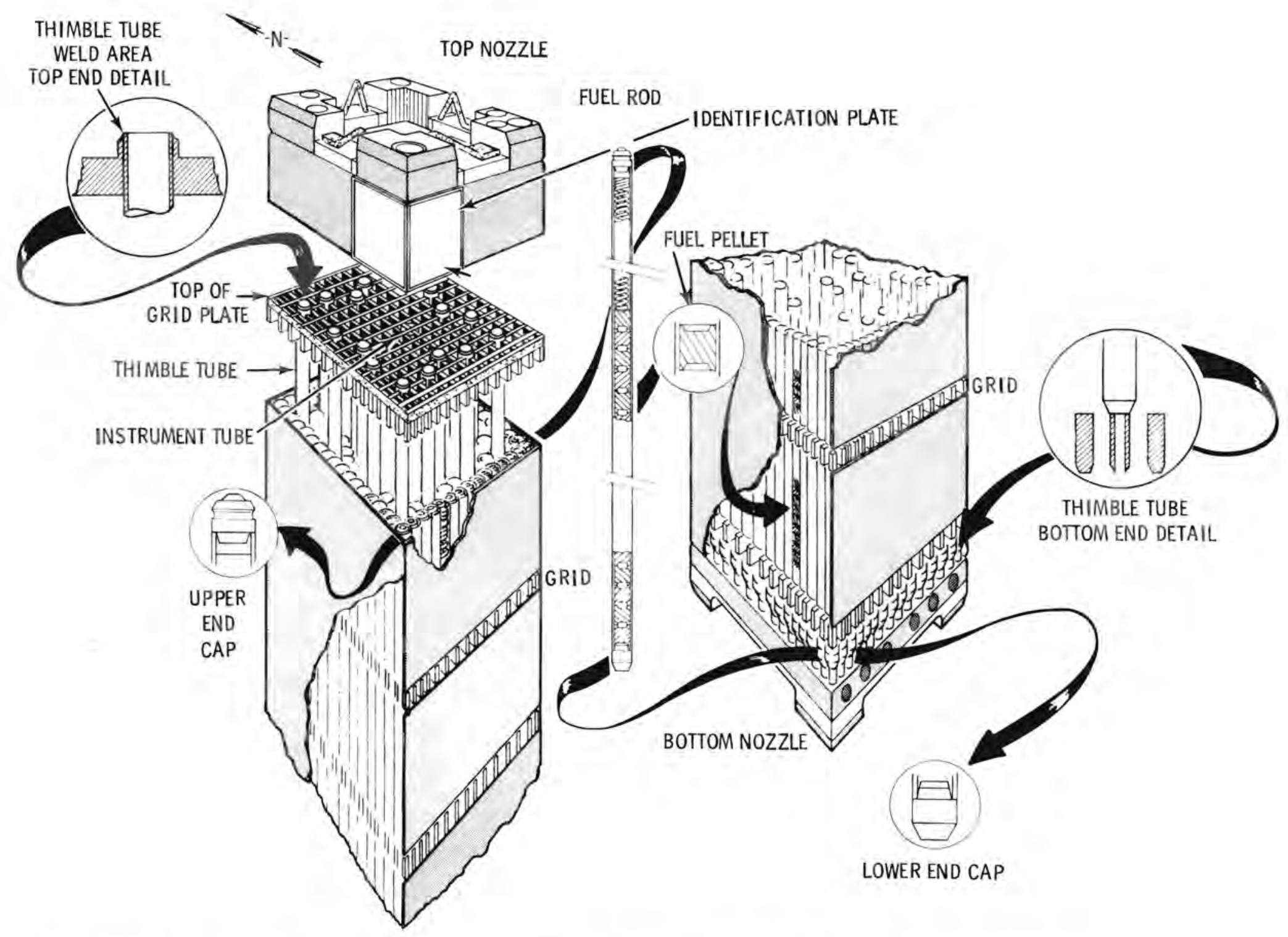

FIGURE 2. Schematic Diagram Showing Structural Features of S004, Including Details of the Thimble Tube Weld Areas 


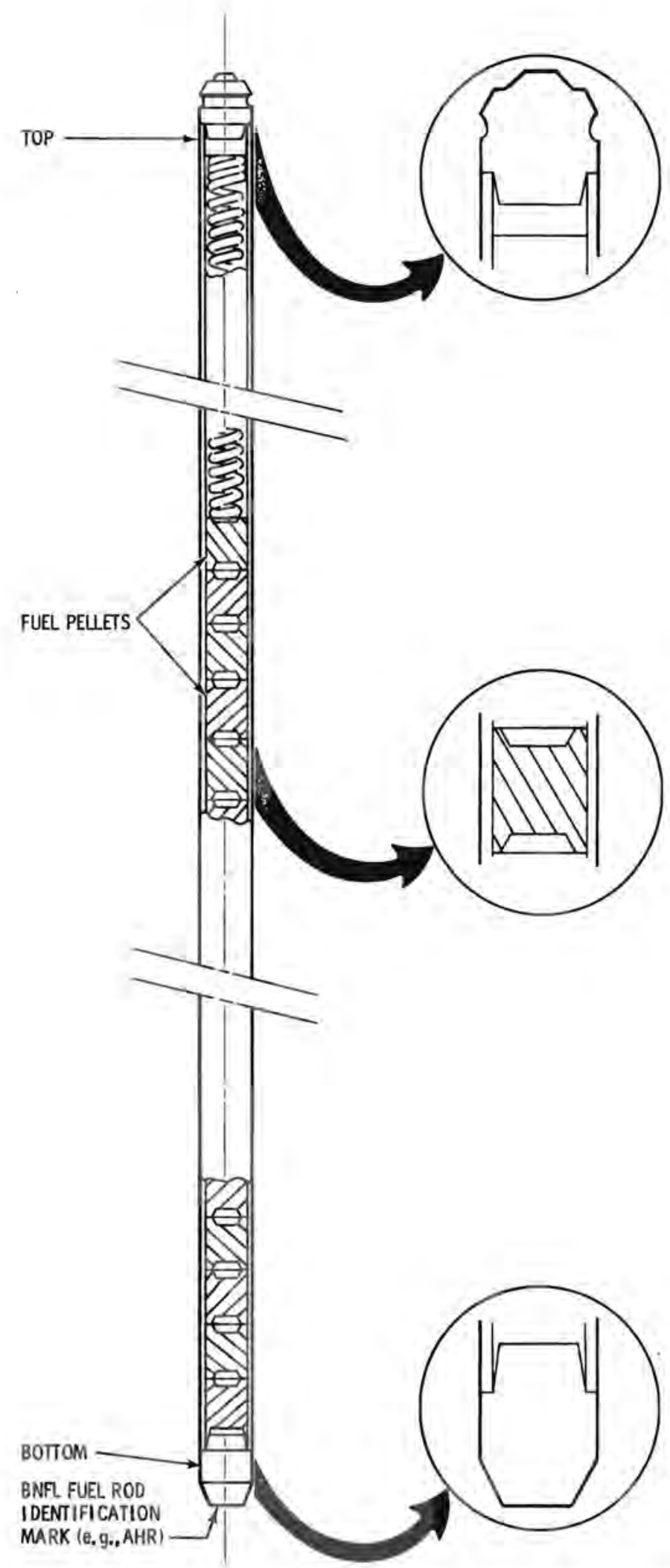

FIGURE 3. Schematic Diagram of Typical Fuel Rod from Fue1 Assembly S004 
CONPOR (Controlled Porosity) fuel (Heal, Littlechild, and Page 1980; Littlechild and Butler 1976; Raven 1976) was used for the pellets. Pellet information is listed in Table 1 . Table 2 lists the fabrication history of the welded and drawn tubing used for fuel rod cladding. The fuel rod loading diagram for $\mathrm{SOO} 4$ is provided in Figure 4.

TABLE 2. Fabrication of Seam-Welded, Stainless Steel Cladding for Fuel Rods MATERIAL: $1.65 \mathrm{~mm}$ thick strip RECEIVING INSPECTION: Physical and Chemical Testing FABRICATION: Bend Strip

Tungsten-Inert Gas Weld

Draw

$\left.\begin{array}{l}\text { Degrease } \\ \text { Solution Anneal }\end{array}\right\}$

Repeat to $0.41 \mathrm{~mm} \mathrm{OD}$

Plug Draw

Degrease

Solution Anneal

Pickle $\left(\mathrm{HNO}_{3}+\mathrm{HF}\right)$

Plug Draw to Final Size (10-15\% Cold-Worked)

Final Pickle $\left(\mathrm{HNO}_{3}+\mathrm{HF}\right)$

TUBE INSPECTION: Straightness

Ovality

Ultrasonic Testing on ID/OD-100\%, Every Tube

CORROSION TEST: Boiling $\mathrm{CUSO}_{4}$ Solution

FUEL IRRADIATION HISTORY

S004 was first irradiated in cycle 3 at Connecticut Yankee. It was removed from the core at the end of cycle 3 for an interim examination. Irradiation continued in cycle 4 and cycle 5. The assembly was discharged from the reactor at the end of cycle 5 and moved to the reactor fuel storage pool. 
NORTH

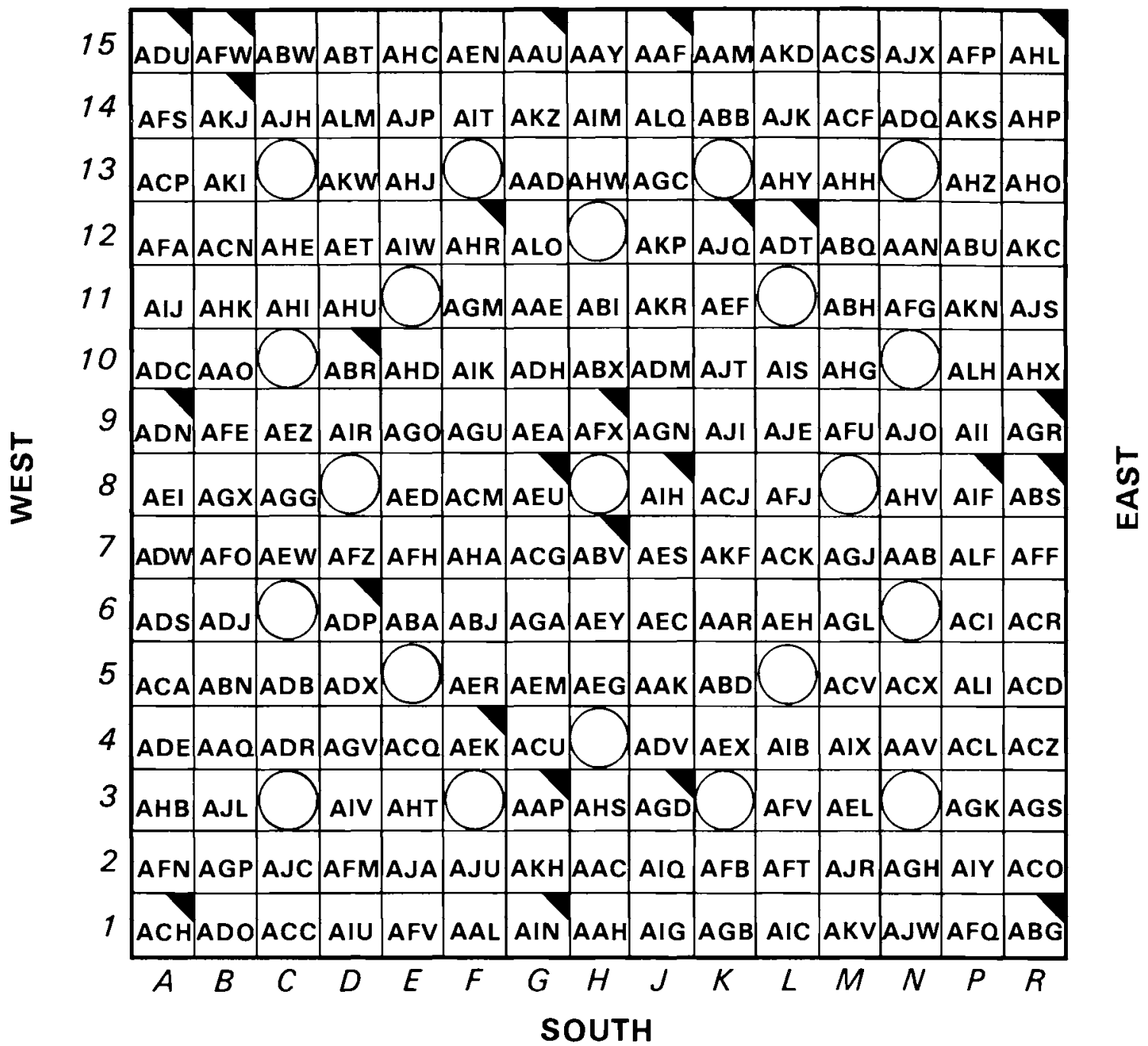

FUEL ROD IDENTITY VISUALLY CONFIRMED AT BCL

FIGURE 4. Fuel Rod Loading Diagram for S004

Assemblies G11 and HO7 (see Introduction) contained fuel from batches 7 and 8 , respectively. The irradiation histories of G11, H07, and $\mathrm{SOO4}$ are summarized in Table 3 and Figure 5. Table 4 describes the S004 irradiation history in greater detail. Figure 6 shows the locations of assemblies S004, G11, and H07 during the various reactor cycles.

Figures 7 and 8 show typical beginning-of-cycle (BOC) and end-of-cycle (EOC) assembly power and end-of-cycle assembly burnup profiles for Connecticut Yankee fuel rods. Figure 9 shows depressions in the flux profiles of assemblies, as measured in Connecticut Yankee. 
TABLE 3. Irradiation and Storage Histories for Connecticut Yankee Fuel Assemblies S004, G11, and H07

\begin{tabular}{|c|c|c|c|c|}
\hline $\begin{array}{c}\text { Assemb ly } \\
\text { Number }\end{array}$ & $\begin{array}{l}\text { Cladding } \\
\text { Material } \\
\end{array}$ & $\begin{array}{c}\text { Fuel Burnup } \\
\text { Average, } \\
\text { MWd/MTU (GJ/kgU) } \\
\end{array}$ & $\begin{array}{l}\text { Pool Storage } \\
\text { Time as of } \\
\text { May } 1980(y r)\end{array}$ & Shutdown Date \\
\hline S004 & $304 L S S$ & $32,151(2788)$ & 5.0 & May 18, 1975 \\
\hline G11 & $304 S S$ & $36,700(3171)$ & 2.6 & October 15,1977 \\
\hline $\mathrm{HO7}$ & $304 S S$ & $35,800 \quad(3093)$ & 1.3 & January 27,1979 \\
\hline
\end{tabular}

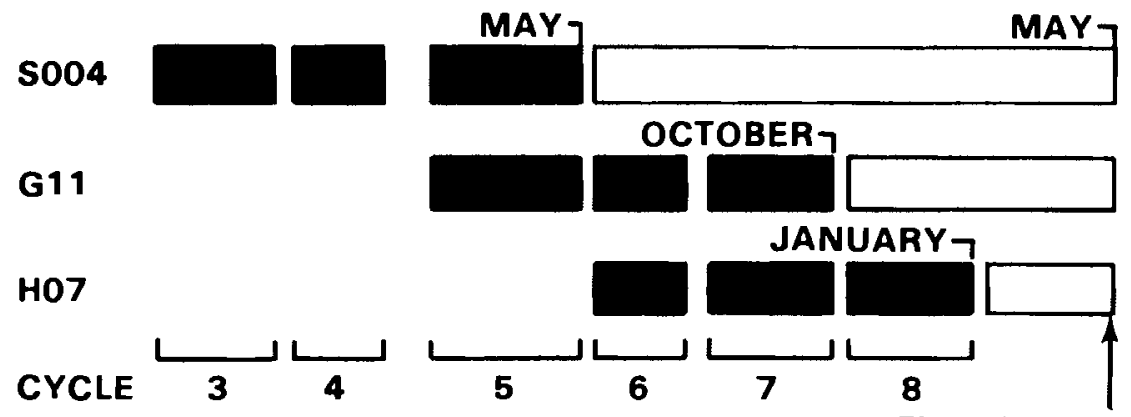

FUEL SHIPMENT

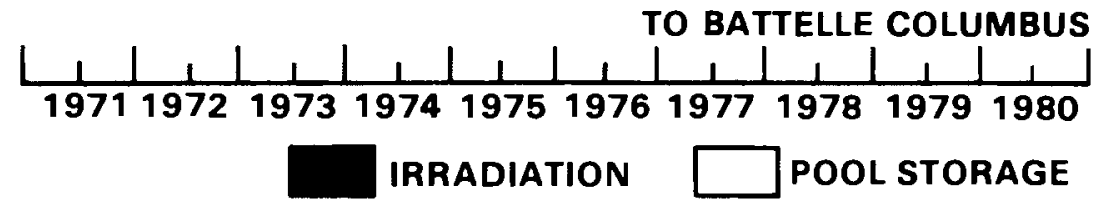

FIGURE 5. Irradiation History of Connecticut Yankee Fuel Assemblies $\mathrm{SOO4,} \mathrm{H} 07$, and G11

TABLE 4. Connecticut Yankee (Haddam Neck) Operating Information During Cycles 3,4 , and 5

\begin{tabular}{|c|c|c|c|}
\hline $\begin{array}{l}\text { Cycle } \\
\text { Number }\end{array}$ & Startup Date & Shutdown Date & $\begin{array}{l}\text { Irradiation Time } \\
\text { Effective Full-Power }\end{array}$ \\
\hline 3 & May 21,1971 & June 15,1972 & 365 \\
\hline 4 & July 8, 1972 & July 18,1973 & 321 \\
\hline 5 & December 14,1973 & May 18,1975 & 460 \\
\hline
\end{tabular}


CONTROL ROD GROUPS

$$
\begin{aligned}
& \text { A } \\
& B \\
& C \\
& D \\
& D^{\star} \quad \text { OLD "B" }
\end{aligned}
$$

CORE NORTH

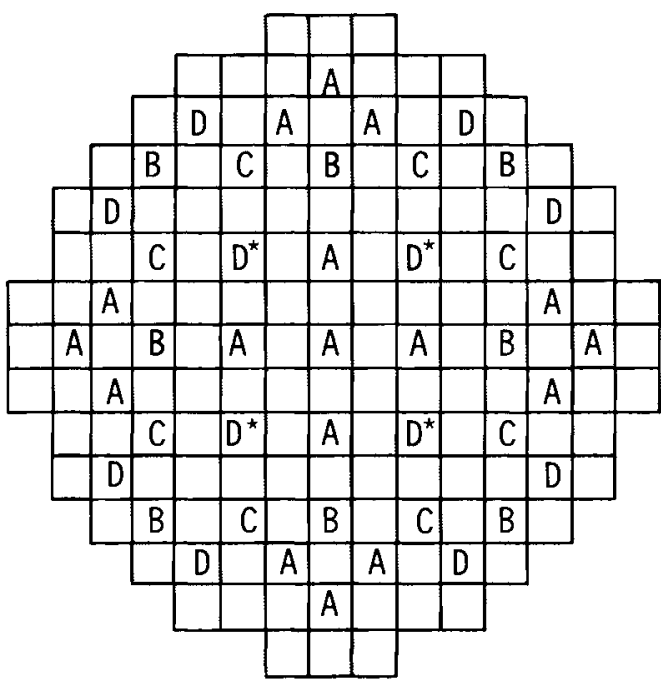

R
$P$
N
$M$
L
K
J
$H$
G
F
E
D
C
B
A

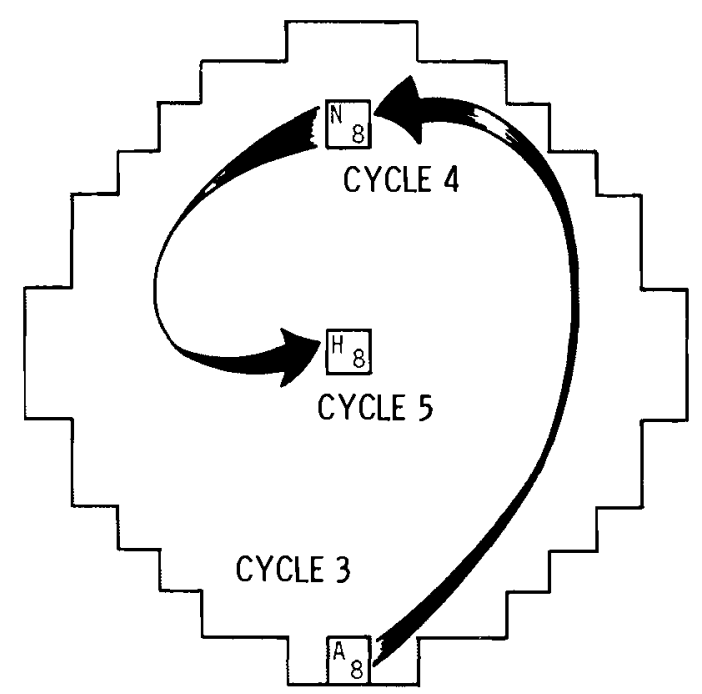

S004

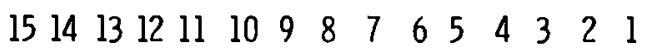
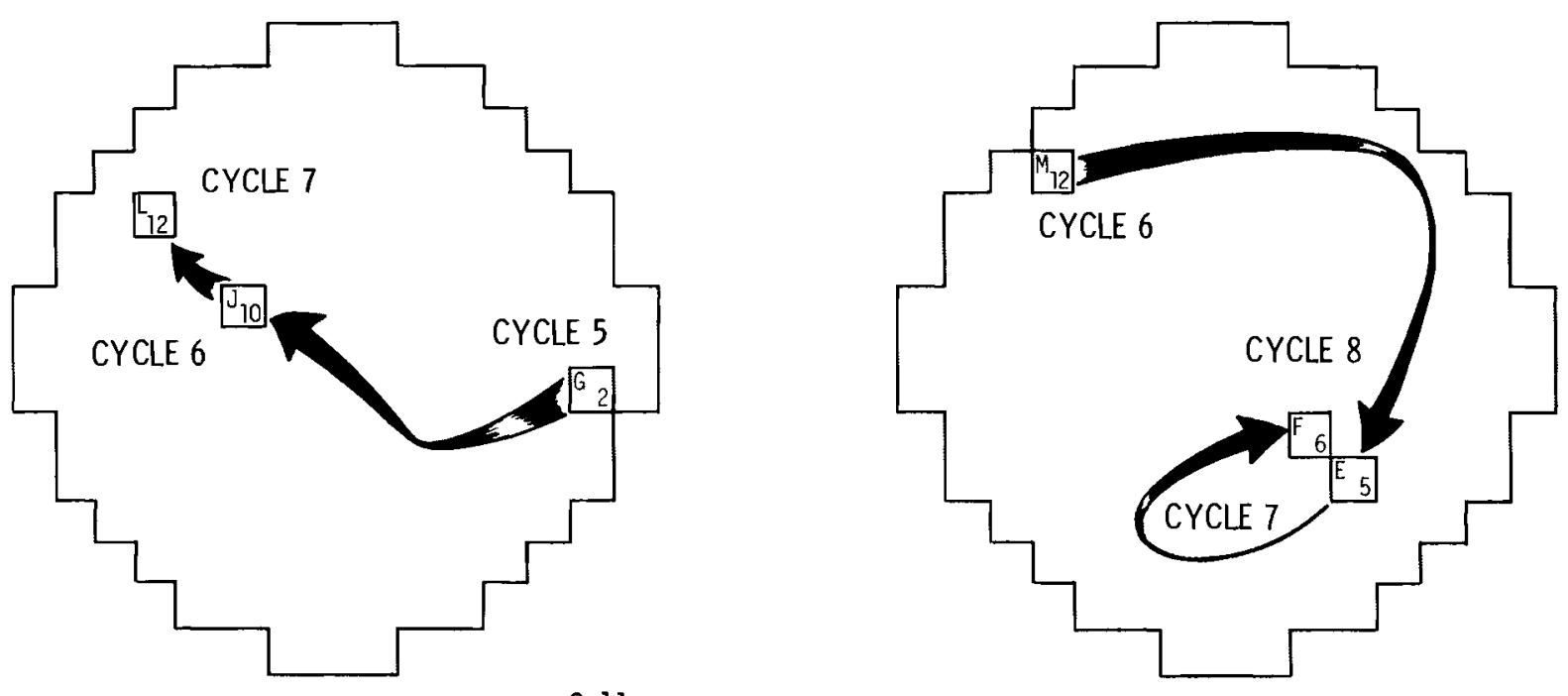

G 11

$\mathrm{HOT}$

FIGURE 6. Locations of Fuel Assemblies S004, G11, and H07 in the Connecticut Yankee (Haddam Neck) Core During Irradiation 


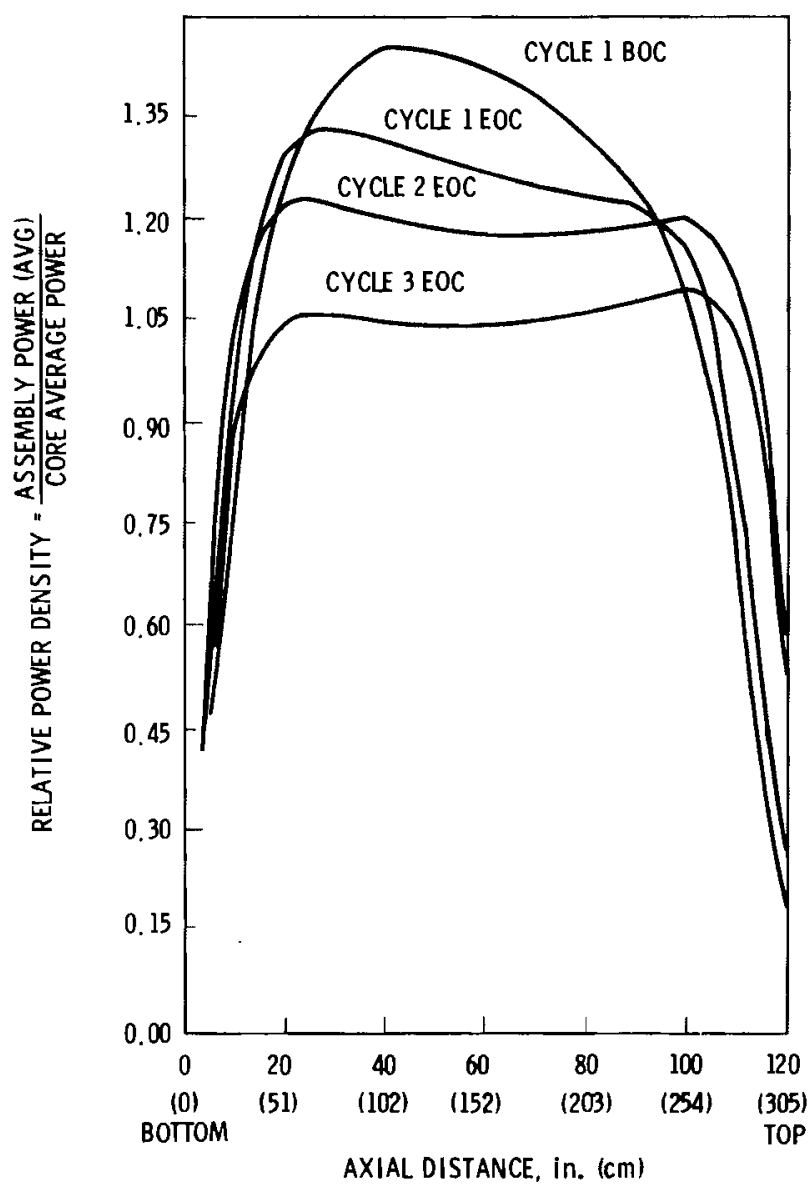

FIGURE 8. Accumulation of Fue 1 Burnup With Continued Irradiation for a Typical PWR Fuel Assembly
FIGURE 7. Change in the Axial Power Profile With Accumulated Fue 1 Burnup For a Typical PWR Fue 1 Assembly ( $\mathrm{BOC}=$ Beginning of Cycle; $E O C=$ End of Cycle).

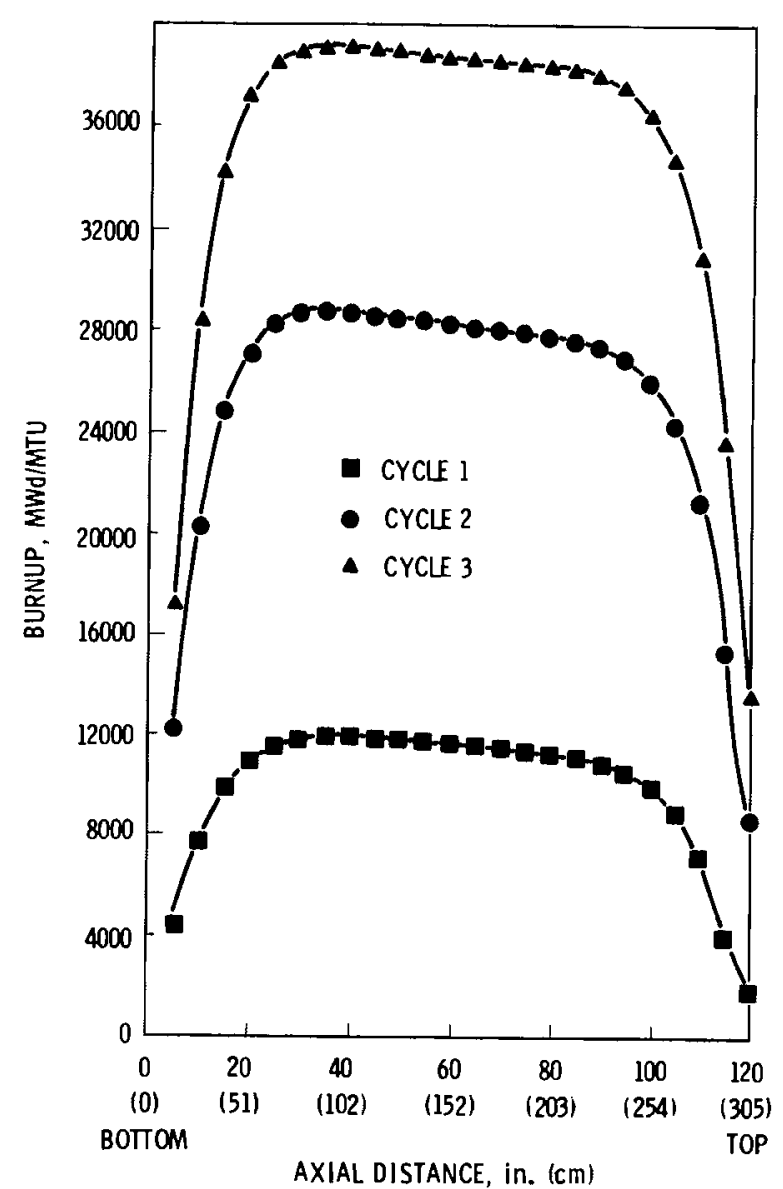




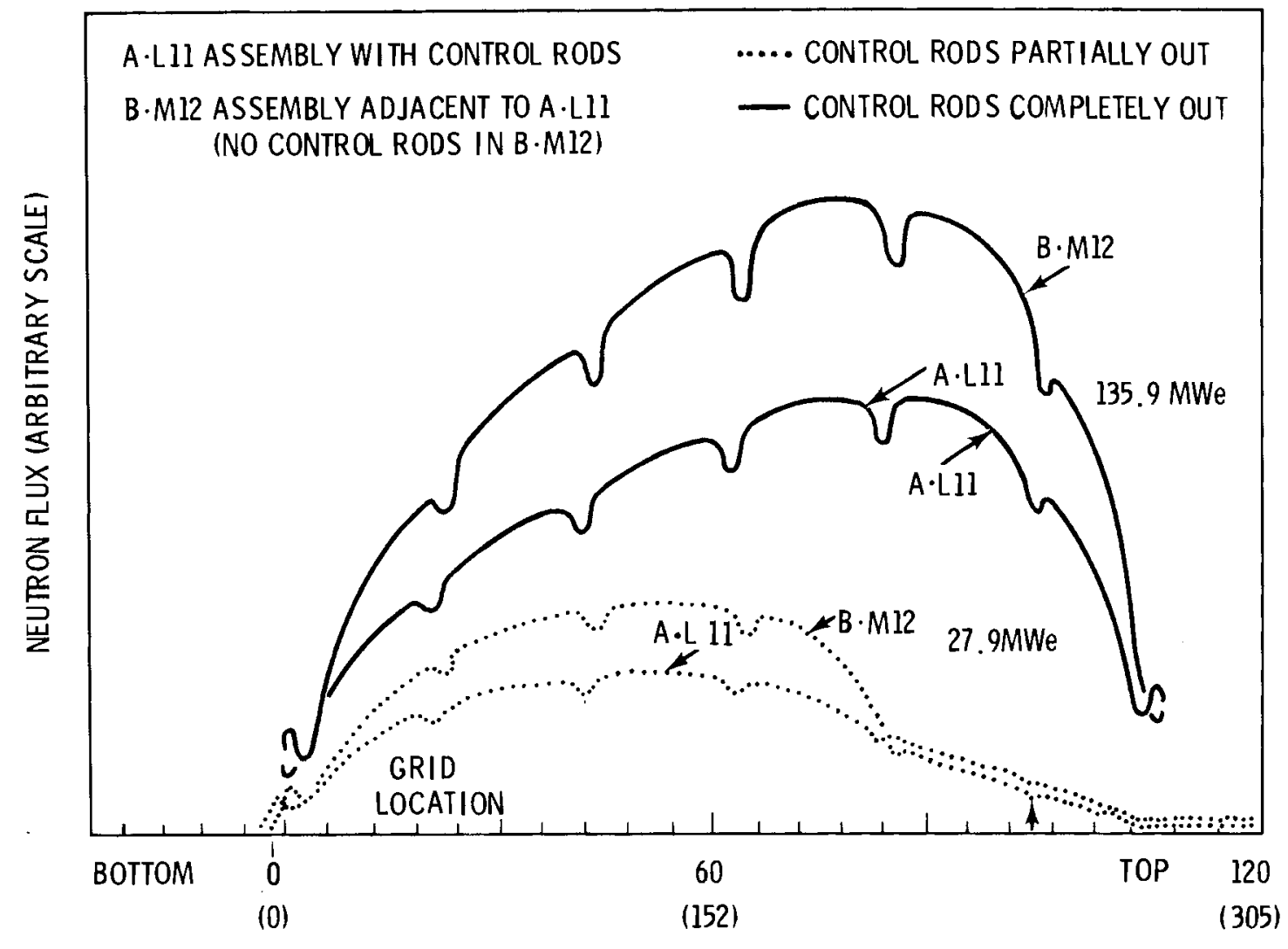

AXIAL DISTANCE, in. (cm)

FIGURE 9. Variation in the Axial Neutron Flux Profile Along Two Fuel Assemblies in Connecticut Yankee

FUEL STORAGE, HANDLING, AND TRANSPORT

Assembly S004 was discharged at end-of-life on May 18, 1975, and placed in the reactor fuel storage pool, where it remained for $5 \mathrm{yr}$. After S004 was selected for examination as part of the Spent Fuel and Fuel Pool component Integrity Program, it was transported to the examination site at $B C L$.

The shipment of 5004 from Connecticut Yankee to the BCL hot-cell facility was arranged with a qualified carrier by NUSCO as part of the NUSCO/PNL agreement. The periods of pool storage for the individual assemblies are listed in Table 3. Poolside examinations were performed on the three assemblies immediately prior to shipment. 
A11 three assemblies were shipped dry. H07 was shipped first, G11 second, and S004 last. H07 contained several fuel rods known to have failed. The cooling period after reactor discharge was 16 months for $\mathrm{H} 07$ compared to 60 months for S004. An increase in the activity of the pool water from $1.1 \times$ $10^{-4}$ to $1.1 \times 10^{-2} \mu \mathrm{Ci} / \mathrm{ml}$ accompanied the unloading of $\mathrm{HO}$ from the shipping cask in the BCL pool (K1ingensmith 1980). The water activity continued at the higher level for 6 weeks. S004 was stored in the BCL pool during this time.

S004 was shipped in an air-filled cask on May 14, 1980, and arrived at the hot-cell facility at $B C L$ on May 15. It was unloaded from the shipping cask in the BCL pool on May 16. Table 5 gives a summary of the nominal environmental conditions encountered by S004 through November 1980 .

\section{FUEL EXAMINATION}

One criterion for selecting a fuel assembly was that it be well characterized. As shown in Table 6, S004 met the requirements. Because S004 was a qualification fuel assembly, BNFL developed preirradiation data on 20 fuel rods. The fuel stack lengths and stack weights were measured. The cladding diameter was measured at three equally spaced azimuthal locations at 10 axial

TABLE 5. Summary of Nominal Environmental Conditions Encountered by Fuel Assembly S004 Through November 1980

\begin{tabular}{|c|c|c|c|}
\hline Par ame ter & $\begin{array}{l}\text { Reactor Core } \\
\text { (Borated Water) } \\
\end{array}$ & $\begin{array}{l}\text { Reactor Pool } \\
\text { (Borated Water) }\end{array}$ & $\begin{array}{l}\text { BCL Storage Pool } \\
\text { (Deionized Water) }\end{array}$ \\
\hline Temperature, ${ }^{\circ} \mathrm{C}$ & $\begin{array}{l}318 \text { Outlet } \\
290 \text { Inlet }\end{array}$ & 41 & $20-25$ \\
\hline $\mathrm{pH}$ at $25^{\circ} \mathrm{C}$ & $5.4-10$ & $4.2-4.8$ & -- \\
\hline Boron, ppm & $0.1-3000$ & $2300-2500$ & - \\
\hline Conductivity, $\mu \mathrm{mho} / \mathrm{cm}$ & $2.4-30$ & $0.62-0.72$ & $0.77-1.25$ \\
\hline Time, Years & 4 & 5 & $1 / 2$ \\
\hline
\end{tabular}


TABLE 6. Examination History of SO04

Examination

Preirradiation $(a)$

Interim(b)

Discharge

Preshipment(c)

Postirradiation 1980, July
Location

British Nuclear Fuels

Ltd., England

Poolside Connecticut Rod Length Yankee Reactor

Poolside, Connecticut Visual

Yankee Reactor

Poolside, Connecticut Yankee Reactor

Battelle Columbus Laboratories, Ohio
Information

Fue 1 Stack Weight, Fue 1 Rod Length, Rod Diameter

Periscope Visual, Rod Diameter

Hot-cell examination results

(a) See Table 7 .

(b) See Table 8.

(c) See Table 9.

locations $30 \mathrm{~cm}(1 \mathrm{ft})$ apart, starting $30 \mathrm{~cm}(1 \mathrm{ft})$ above the bottom of each rod. Table 7 summarizes results of the BNFL measurements on the rods in the as-fabricated (i.e., preirradiation) condition.

At end of cycle 3 , lengths of six fuel rods were measured in the reactor pool (see Table 8) by Gulf General Atomic. The results indicated that changes in length were negligible.

The next examination was conducted by Combustion Engineering(a) and NUSCO personnel on May 6, 1980, before the assembly was shipped to BCL (see Table 9). The assembly was examined visually with an underwater periscope in the Connecticut Yankee pool. Several other fuel assemblies from Connecticut Yankee were also examined at that time, among them G11 and H07. Some color pictures were taken with a $35 \mathrm{~mm}$ camera (see Figures 10 and 11 for black-andwhite reproductions).

(a) Combustion Engineering, Windsor, Connecticut, was a consultant to NUSCO. 
TABLE 7. Characterization of Selected S004 Fuel Rods in the As-Fabricated Condition at BNFL

\begin{tabular}{|c|c|c|c|c|c|}
\hline $\begin{array}{c}\text { Fuel } \\
\text { Rod (a) }\end{array}$ & $\begin{array}{r}\text { Rod (b) } \\
\text { Location } \\
\end{array}$ & $\begin{array}{c}\text { Pellet } \\
\text { Batch No. }\end{array}$ & $\begin{array}{l}\text { Fuel Stack } \\
\text { Weight }(\mathrm{kg}) \\
\end{array}$ & $\begin{array}{c}\mathrm{kr} \\
\text { Count } \\
\end{array}$ & $\begin{array}{c}\text { Rod } \\
\text { Length (in.) }\end{array}$ \\
\hline $\mathrm{ACH}$ & A01 & S26 & 2.264 & 912 & $126.665^{(c)}$ \\
\hline ADO & B01 & S22 & 2.265 & 804 & 126.651 \\
\hline AFQ & P01 & S36/S27 & 2.260 & 1072 & 126.669 \\
\hline$A B G$ & R01 & $\$ 26$ & 2.264 & 858 & 126.671 \\
\hline AGV & D04 & S34 & 2.270 & 789 & 126.653 \\
\hline AEK & F04 & S21 & 2.280 & 974 & 126.663 \\
\hline ADP & D06 & $\$ 34$ & 2.256 & 889 & 126.643 \\
\hline ADW & A07 & S34 & 2.259 & 870 & 126.660 \\
\hline AFF & R07 & S22 & 2.266 & 993 & 126.651 \\
\hline AEI & A08 & S21 & 2.260 & 936 & 126.663 \\
\hline ABS & R08 & $\$ 36$ & 2.256 & 962 & 126.661 \\
\hline ADN & A09 & $\$ 21 / S 22$ & 2.271 & 967 & 126.664 \\
\hline AGR & R09 & S27 & 2.264 & 914 & 126.673 \\
\hline$A B R$ & D10 & S34 & 2.272 & 928 & 126.656 \\
\hline AET & D12 & $S 34 / S 21$ & 2.264 & 952 & 126.669 \\
\hline AHR & F12 & $\$ 34$ & 2.258 & 959 & 126.657 \\
\hline ADU & A15 & S34 & 2.258 & 967 & 126.659 \\
\hline AFW & B15 & S26 & 2.264 & 932 & 126.667 \\
\hline AFP & P15 & S26 & 2.263 & 897 & 126.662 \\
\hline AHL & R15 & S26 & 2.262 & 851 & 126.679 \\
\hline
\end{tabular}
(a) See Figures 3 and 4.
(b) See Figure 12 .
(c) 126.665 in. $=321.729 \mathrm{~cm}$. 
TABLE 8. Fuel Rod Length Measurements for Fuel Assembly S004 After One Cycle of Irradiation

\begin{tabular}{|c|c|c|c|c|c|}
\hline Rod & Location (a) & $\begin{array}{l}\text { As-Fabricated } \\
\text { Fuel Rod Length } \\
\text { (in.) }\end{array}$ & $\begin{array}{l}\text { Measured } \\
\text { Length } \\
\text { (in) } \\
\end{array}$ & $\begin{array}{c}\begin{array}{c}\text { Actua } \\
\text { Length } \\
(\text { in. }) \\
\end{array} \\
\end{array}$ & $\begin{array}{l}\text { Fuel Rod Length } \\
\text { Increase (in.) }\end{array}$ \\
\hline $\mathrm{ACH}^{(\mathrm{C})}$ & $\mathrm{A} 01$ & $126.671^{(d)}$ & 126.667 & $\overline{126.678}$ & $0.007^{(\mathrm{e})}$ \\
\hline AIG & J01 & 126.673 & 126.667 & 126.678 & 0.005 \\
\hline$A B G^{(c)}$ & R01 & 126.659 & 126.653 & 126.664 & 0.005 \\
\hline $\operatorname{ADU}^{(C)}$ & A15 & 126.665 & 126.655 & 126.666 & 0.001 \\
\hline AAY & $\mathrm{H} 15$ & 126.663 & 126.663 & 126.674 & 0.011 \\
\hline$A H L(c)$ & R15 & 126.679 & 126.671 & 126.682 & 0.003 \\
\hline
\end{tabular}

(a) Rod location system described in Figure 12.

(b) Measured length corrected for temperature.

(c) Fuel rods precharacterized by BNFL.

(d) 126.671 in. $=321.744 \mathrm{~cm}$.

(e) $0.007 \mathrm{in.}=0.18 \mathrm{~mm}$.

Crud patterns on S004 were similar to those on G11. S004 had several apparent anomalies (Table 9) including a fuel rod with a location that appeared to be bulged, based on underwater examination; a rod with a small elliptical black spot; and two features on a third rod that posssibly could have been cladding cracks. Also, the four corner rods in S004 were not resting on top of the lower nozzle plate. The observed anomalies are called "apparent" because none of them were observed during the subsequent detailed examination at the BCL hot-cell facility. Poolside observations of components being examined by underwater periscope are occasionally subject to optical distortions. The results of the visual inspection of S004 by periscope are given in Table 9. The convention used to describe the locations of fuel rods in the assembly and of grid spacers and rod spans between spacers is shown in Figure 12. 
TABLE 9. Results of Visual Examination of Assembly S004(a) by Underwater Per iscope. (Th is examination was performed by Combustion Engineering and took place prior to the shipment of assembly S004 to the BCL hot-cell facility.)

Fue 1

Assembly Face

Observed

East

$\frac{\text { Rod }}{\text { AHL }} \frac{\text { Location }}{\text { (b) }} \frac{\operatorname{Span}^{(c)}}{5}$

5

Observation

East

AGR

R09

5

Fuel rod definitely bulged.(d)

East

ALF

P07

6

Approximately $1 / 8-i n$. (3-mm) long elliptical black spot.

North

AJX

N15

5

Two apparent small cladding cracks or cracked deposits. (d)

West

AFA

A12

3

Partially decrudded elliptical surface discolorations.

South

$--$

No anomalies on this face.

(a) The four corner rods were not seated on the bottom tie plate in this assembly. At the interim inspection, measurements were made on three of the four rods to determine the force necessary to pull the rods axially.

(b) Rod location and span identified in Figure 12.

(c) Fuel assembly ID not verifiable. Face and rod location indicated assumes maintenance of core orientation in spent fuel storage.

(d) Subsequent hot-cell examinations showed this observation to be incorrect. 


\section{H359-2}

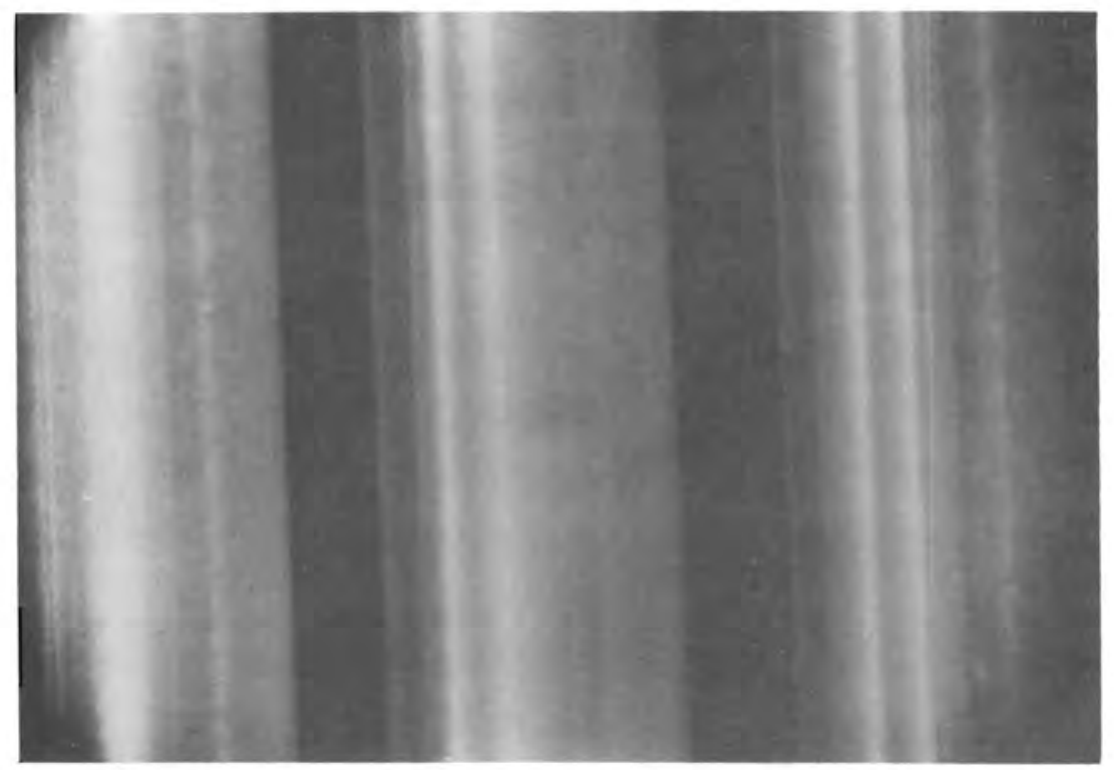

\section{$10 \mathrm{~mm}$}

FIGURE 10a. Periscope Photograph Illustrating Typical Appearance of Fuel Rods in Assembly S004 at Connecticut Yankee During Preshipment Poolside Examination

\section{H359-1}

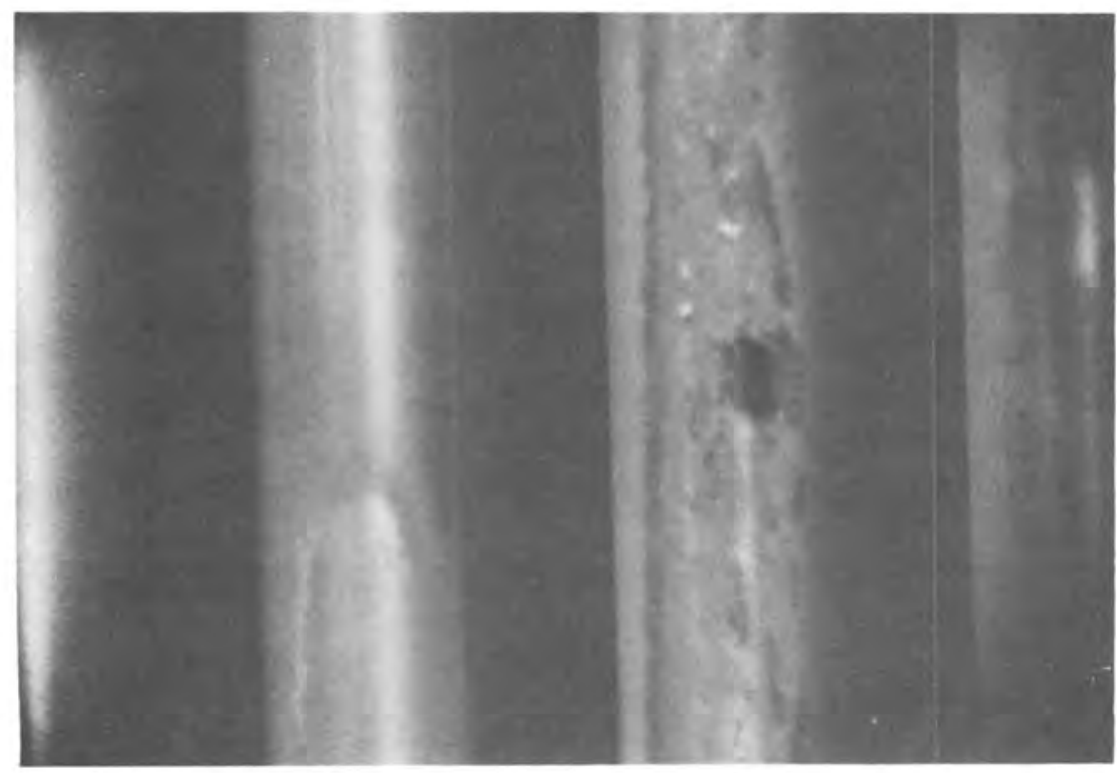

\section{$10 \mathrm{~mm}$}

FIGURE 10b. Small Elliptical Black Spot Observed on Fuel Rod in Assembly S004 at Connecticut Yankee During Preshipment Poolside Examination (from Periscope Color Photograph) 


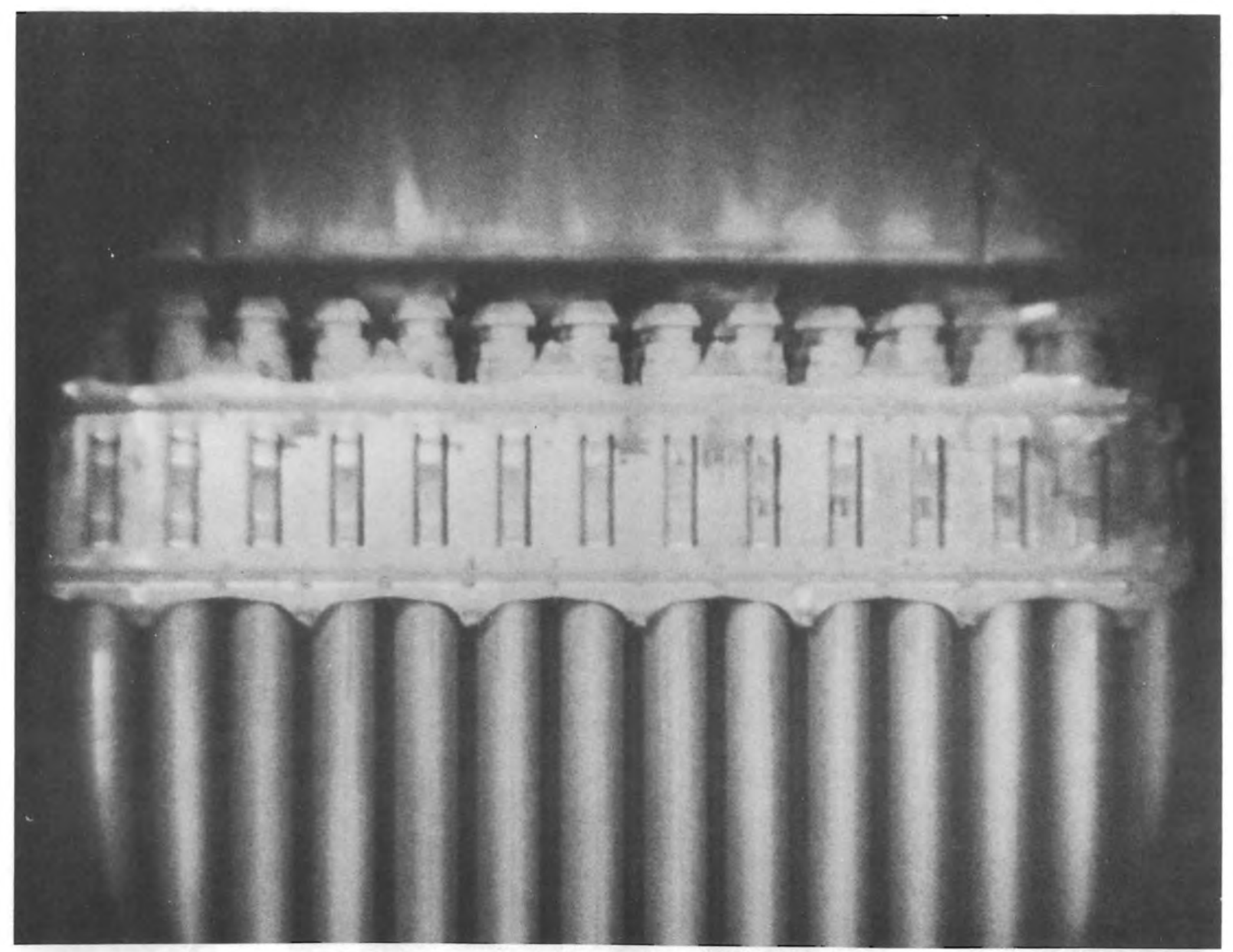

FIGURE 11a. Periscope Photograph Illustrating Typical Appearance of Fuel Rods Including Upper End Caps and Grid Spacer Near Top Nozzle in Assembly G11 at Connecticut Yankee During Preshipment Examination (South Face) 
81F342-2 FROM CN R19-2

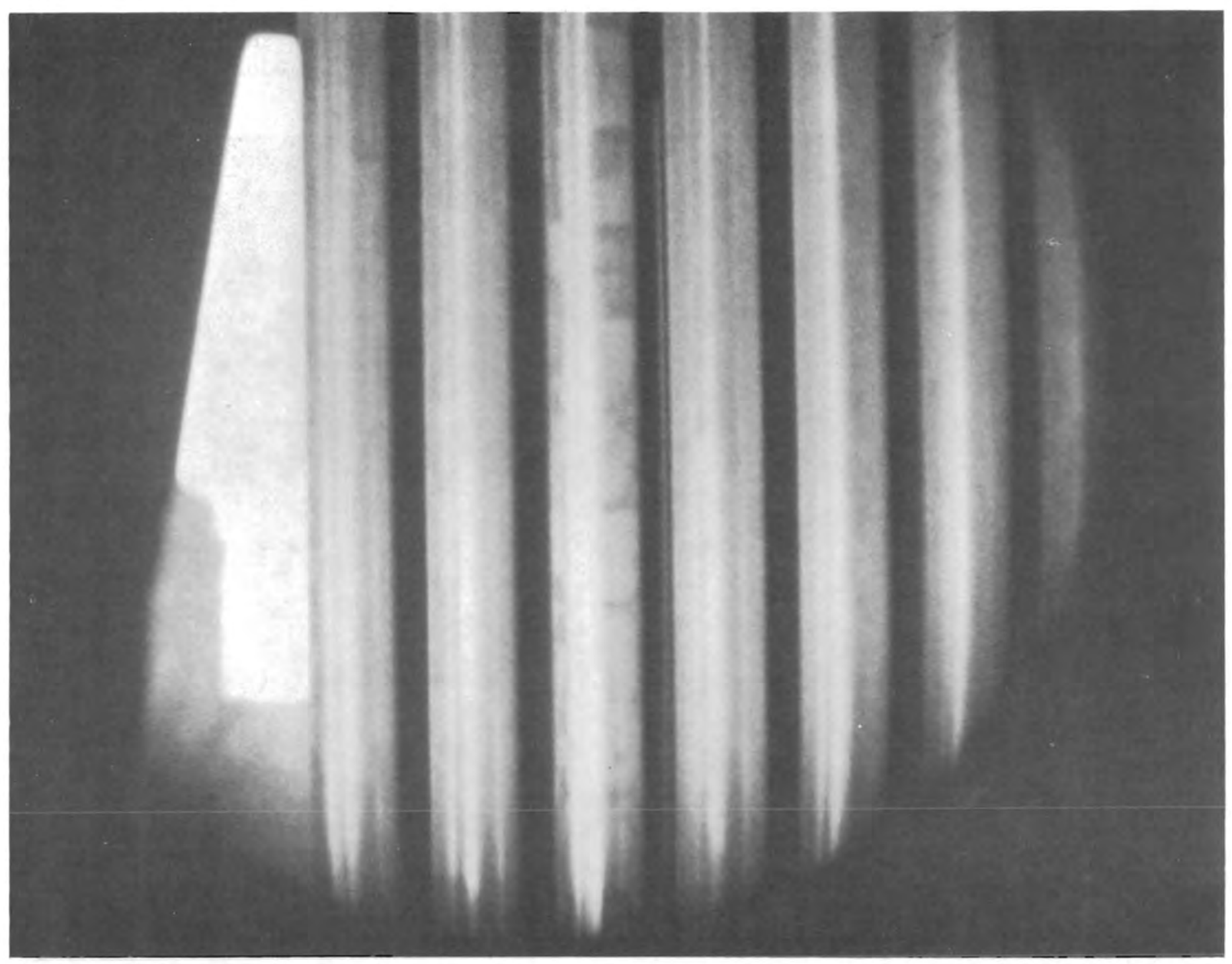

FIGURE 11b. Mottled Appearance of Rod Surface Coinciding with Pellet Interface Locations in Assembly S004 at Connecticut Yankee During Preshipment Examination (Span 5, West Face) 


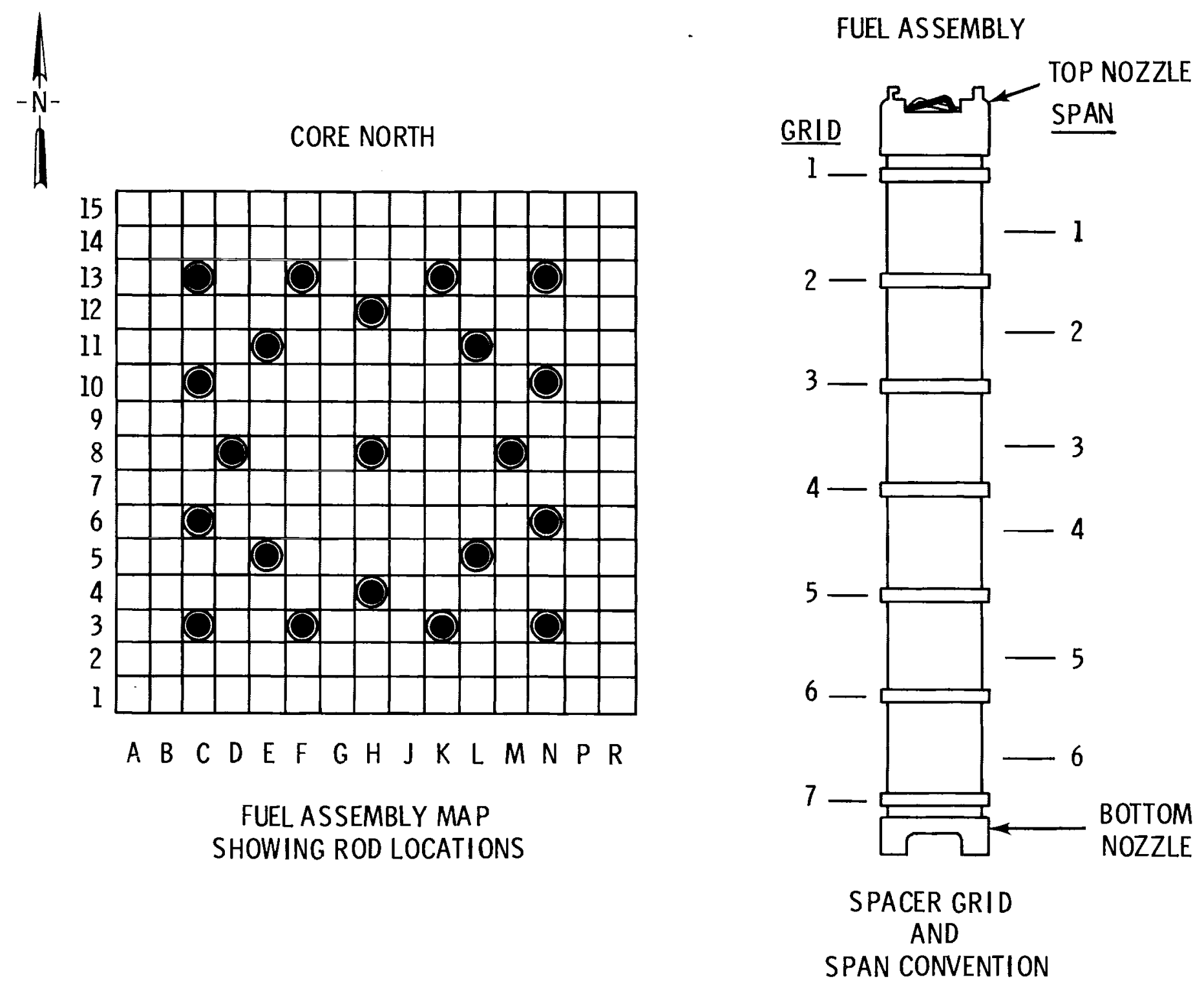

FIGURE 12. Convention Used in This Report To Describe Fue 1 Rod Locations in the Assembly and Axial Locations of Spacer Grids and Spans 
. 


\section{FUEL CHARACTERIZATION RESULTS}

Fuel characterization, as used in this report, refers to establishing the present condition of the fuel so that the effects of irradiation and initial pool storage can be determined. Furthermore, by providing a reference condition, significant changes, if they were to occur during subsequent extended pool storage, could be detected. For the SOO4 examination, both nondestructive and destructive tests were made to determine selected chemical, physical, and mechanical parameters.

Nondestructive examinations were performed on the fuel assembly and also on individual fuel rods. Fuel assembly inspection techniques included sipping (for detecting breached fuel rod cladding with in the assembly) and visual examination. Fuel rod inspection techniques included visual examination, profilometry, gamma scanning, eddy current testing, and temperature measurement. The specific examinations performed are shown in Table 10.

TABLE 10. Summary of Nondestructive Examinations Completed on Fuel Rods Removed From Fuel Assembly SO04

\begin{tabular}{|c|c|c|c|c|c|c|c|c|}
\hline Rod & $\begin{array}{l}\text { Location in } \\
\text { Assembly (a) }\end{array}$ & $\begin{array}{l}\text { Profile } \\
\text { Spiral } \\
\end{array}$ & $\begin{array}{l}\text { Profile } \\
\text { Linear }\end{array}$ & $\begin{array}{c}\text { Videotape } \\
\text { Visual } \\
\end{array}$ & $\begin{array}{c}\text { Eddy } \\
\text { Current } \\
\end{array}$ & $\begin{array}{c}\text { Gamma } \\
\text { Scan } \\
\text { (Gross) } \\
\end{array}$ & $\begin{array}{l}\text { Gamma } \\
\text { Scan } \\
(137 \mathrm{Cs}) \\
\end{array}$ & $\begin{array}{l}\text { Rod } \\
\text { Weight }\end{array}$ \\
\hline AHL & R15 & $x$ & - & $x$ & $x$ & $x$ & $x$ & $x$ \\
\hline AGR & R09 & - & - & $x$ & - & - & - & $x$ \\
\hline ALF & P07 & - & - & $x$ & - & - & - & $x$ \\
\hline$A B G$ & R01 & $x$ & - & $x$ & - & $x$ & $x$ & $x$ \\
\hline AEK & FO4 & $x$ & - & $x$ & $x$ & - & $x$ & $x$ \\
\hline AAP & $\mathrm{GO3}$ & - & - & $x$ & $x$ & - & - & $x$ \\
\hline AHR & $F 12$ & $x$ & $x$ & $x$ & $x$ & - & $x$ & $x$ \\
\hline AJQ & $\mathrm{K} 12$ & $x$ & - & $x$ & $x$ & - & $x$ & - \\
\hline
\end{tabular}

(a) See Figure 12 for location convention. 
Destructive examinations were performed on individual fuel rods and included fission gas collection and analys is, void volume determination, rod marking and sectioning, metallographic examination of the fuel and cladding, burnup analysis, autoradiography, fuel density determinations, and cladding mechanical property testing. The specific examinations and specimen locations are listed in Table 11 and are shown in Figure 13.

\section{NONDESTRUCTIVE EXAMINATIONS OF FUEL ASSEMBLY}

The S004 fuel assembly was examined to determine whether any change in assembly condition had occurred between the poolside visual examination at Connecticut Yankee and the visual examination at $\mathrm{BCL}$.

\section{Sipping Test}

When the fuel assembly arrived at $\mathrm{BCL}$ on May 15, 1980, the shipping cask underwent a wet sipping test (see Table 12) prior to removal of the fuel assembly. The test results indicated that the fuel rods had not released fission products during shipping. The cask and fuel were transferred to the $B C L$ fuel pool on May 16, and the fuel assembly was removed from the cask.

TABLE 11. Spent Fuel Destructive Examination Plan

$\begin{array}{lllllllll}\text { Rod } & \frac{(a)}{x H R} & \frac{(b)}{x} & \frac{(c)}{x} & \frac{(d)}{x} & \frac{(e)}{x} & \frac{(f)}{x} & \frac{(g)}{x} & \frac{(h)}{x} \\ A B G & x & x & & & & & & \\ A D T & x & & & & & & \\ \text { AGD } & x & & & & \end{array}$

(a) Rod puncture and gas collection, void volume determination, and gas analys is

(b) Fuel and cladding preparation and photomicrography (transverse)

(c) Autoradiography (alpha and beta-gamma)

(d) Fuel burnup analys is

(e) Fuel density measurements

(f) Tensile tests

(g) Ring crush tests (side-pressing)

(h) Cladding-to-end cap weld metallography (longitudinal sections) 

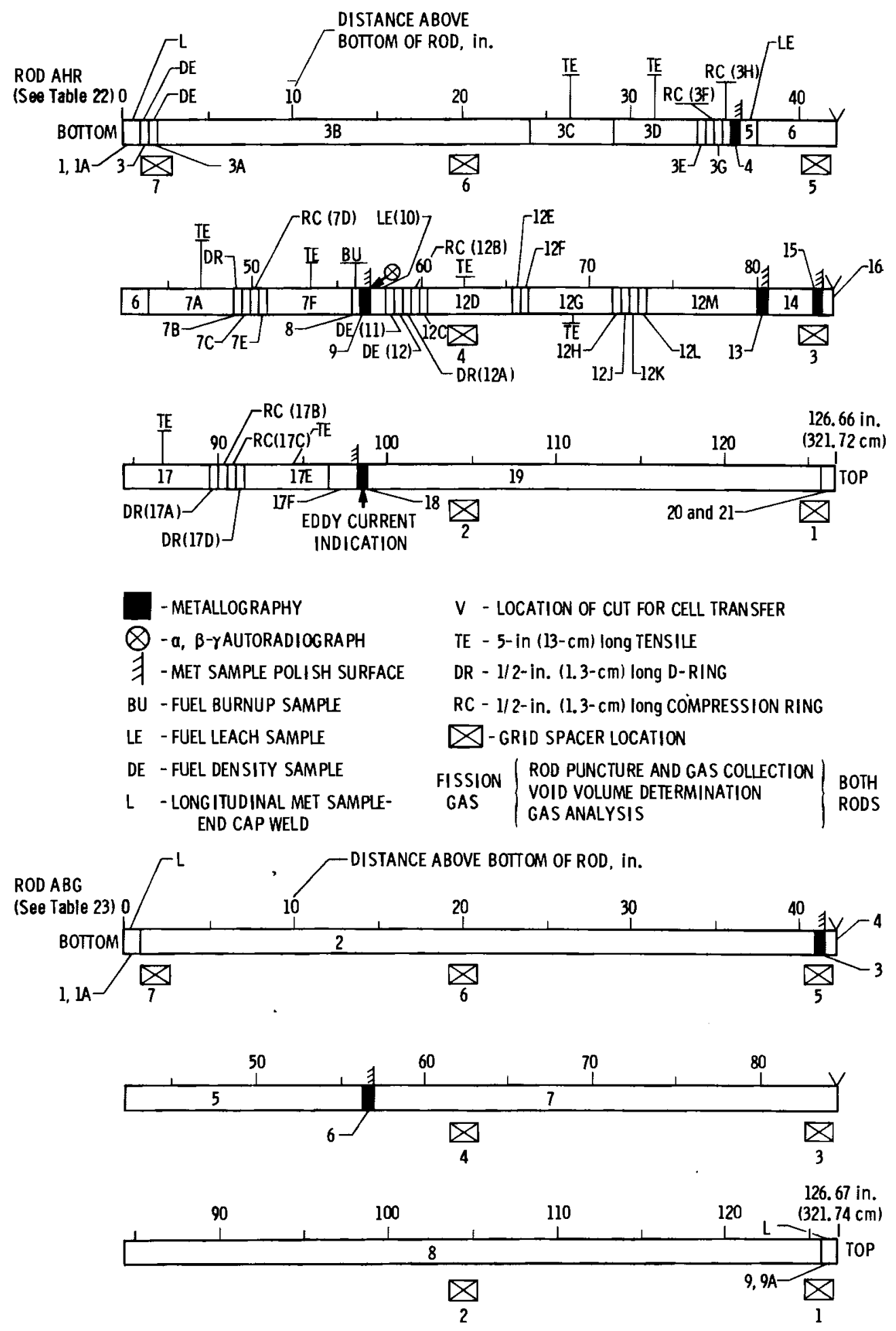

FIGURE 13. Specific Destructive Examinations and Specimen Locations 
TABLE 12. Results from wet Sipping Test of Shipping Cask at BCL Before Assembly $\mathrm{S} 004$ Was Removed. (The test involves gamma ray isotopic analysis.)

\begin{tabular}{|c|c|c|c|}
\hline \multirow[b]{2}{*}{ Sample (Date) } & \multicolumn{3}{|c|}{ Radioactivity, $\mu \mathrm{Ci} / \mathrm{ml}$} \\
\hline & Ces ium-137 & Cesium-134 & Cobalt-60 \\
\hline First Flush $(5 / 15 / 80)$ & $5.8 \times 10^{-3}$ & $3.0 \times 10^{-3}$ & $5.4 \times 10^{-1}$ \\
\hline 1-hr Soak $(5 / 15 / 80)$ & $1.2 \times 10^{-3}$ & $4.2 \times 10^{-4}$ & $9.1 \times 10^{-2}$ \\
\hline Overnight Soak $(5 / 16 / 80)$ & $7.4 \times 10^{-4}$ & $6.1 \times 10^{-4}$ & $7.9 \times 10^{-2}$ \\
\hline
\end{tabular}

The BCL Hot Laboratory sipping procedure for spent fuel shipping casks consists of first flushing the cask with water and then letting water stand in the cask. Samples are collected: a) immediately after flushing, b) after standing $1 \mathrm{hr}$, and c) after standing $24 \mathrm{hr}$. The concentration of radioactive material in each sample is then measured.

The cask was back-filled with demineralized water and flushed for 10 to 15 min. A sample was taken to establish a value for background radiation. A value of $5.8 \times 10^{-3} \mu \mathrm{Ci} / \mathrm{ml}$ of ${ }^{137} \mathrm{Cs}$ was measured. The water was left in the cask for $1 \mathrm{hr}$ and then a second sample was taken. The ${ }^{137} \mathrm{Cs}$ activity decreased to $1.2 \times 10^{-3} \mu \mathrm{Ci} / \mathrm{ml}$. A third sample was taken after a soak time of approximately $24 \mathrm{hr}$. The ${ }^{137} \mathrm{CS}$ activity continued to decrease to $7.4 \times 10^{-4} \mu \mathrm{Ci} / \mathrm{ml}$. A decrease in the ${ }^{137}$ Cs activity level in the cask with time indicated that none of the fuel rods in the assembly were leaking fission products.

\section{Visual Examination}

The fuel assembly was visually examined in the BCL pool with a videotape system. The fuel rods appeared clean. There was no obvious assembly distortion. The system image was of limited clarity and none of the anomalies of the previous periscope examination were observed. Further discussion of the anomalies follows in the section on fuel rod visual examinations.

The top nozzle (Figures 14 and 15) of the fuel assembly was visually examined in air prior to removal from the assembly. Some orange-colored spots were observed near the tops of some of the guide tubes. The top nozzle was removed by drilling out the guide tube-to-nozzle welds on four guide tubes and cutting 


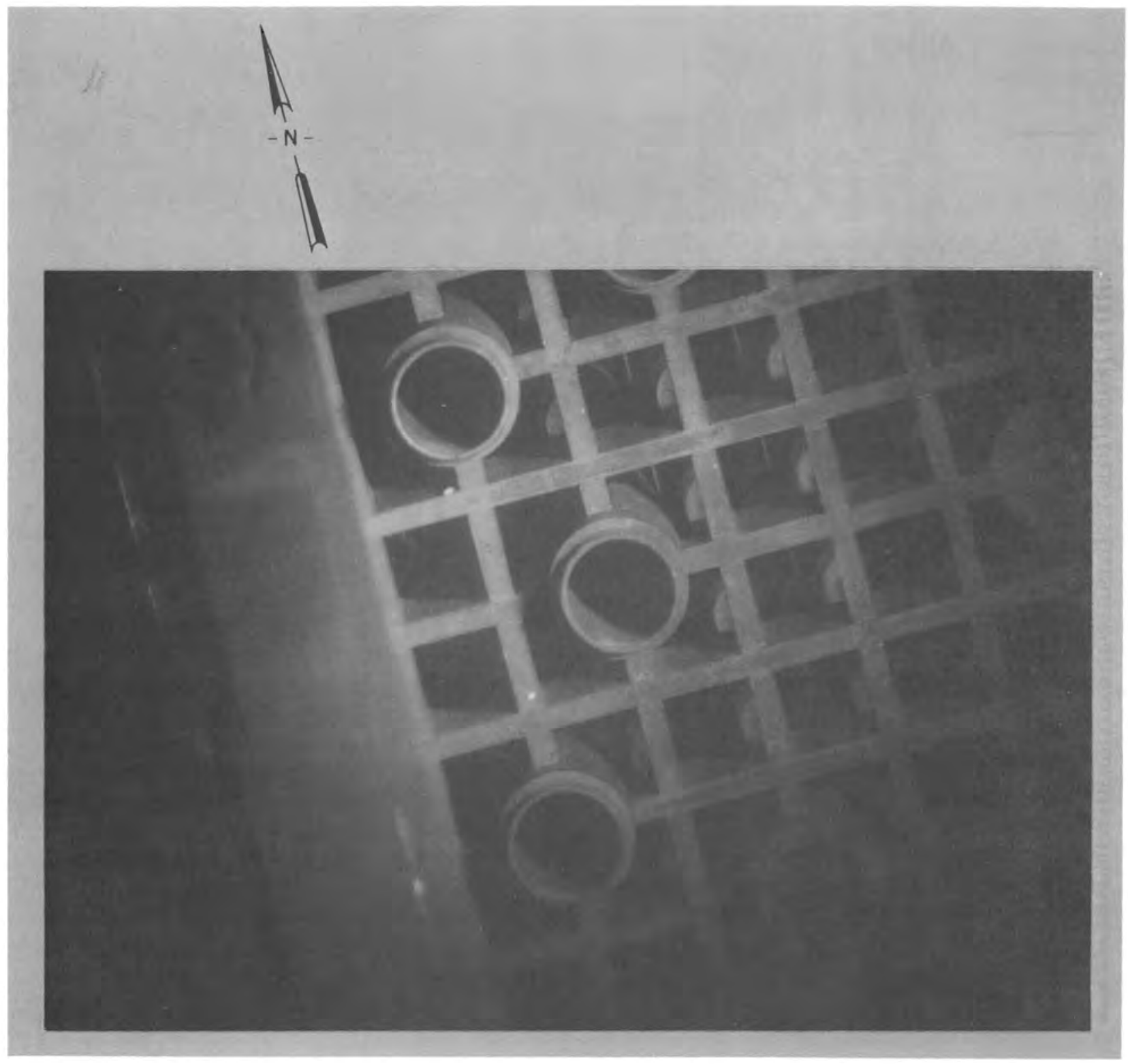

FIGURE 14. Inner Portion of the Top Nozzle Plate of S004 Showing Nozzle Grid, Upper Thimble Tube Welds, and Fuel Rod Upper End Caps (from periscope color photograph taken during visual examination at the $\mathrm{BCL}$ hot-cell facility)

off the other guide tubes just below the nozzle. Eight fuel rods were removed for nondestructive examination; four of the eight were selected for destructive examination (see Tables 10 and 11). The criteria for selection were the presence of anomalies in the previous visual examination and a high calculated fuel burnup. For fuel rods in 5004 , high burnup was $2978 \mathrm{GJ} / \mathrm{kgU}$ (34,470 MWd/MTU); low burnup was $2139 \mathrm{GJ} / \mathrm{kgU}(24,750 \mathrm{MWd} / \mathrm{MTU})$. 


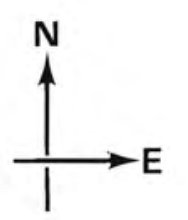

\section{C9368}

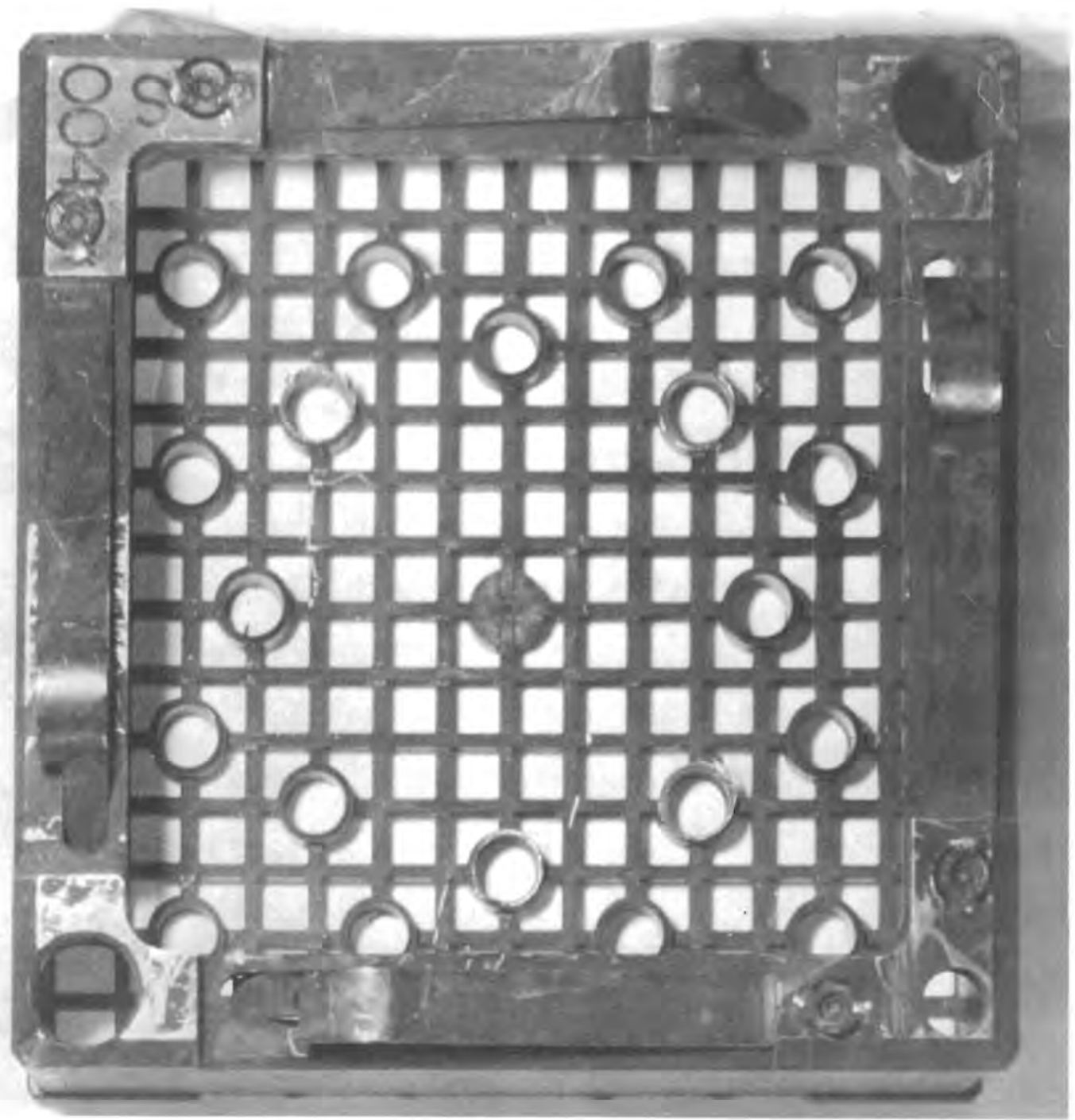

FIGURE 15a. Top View of Top Nozzle

\section{NONDESTRUCTIVE EXAMINATIONS OF FUEL RODS}

Fuel rods selected to characterize the S004 assembly were nondestructively examined to establish a baseline for subsequent examinations during extended pool storage.

\section{Visual Examination}

Some fuel rods had dull reddish surfaces, which is indicative of an oxide film or a crud layer (see Figure 10). Later metallurgical examinations 


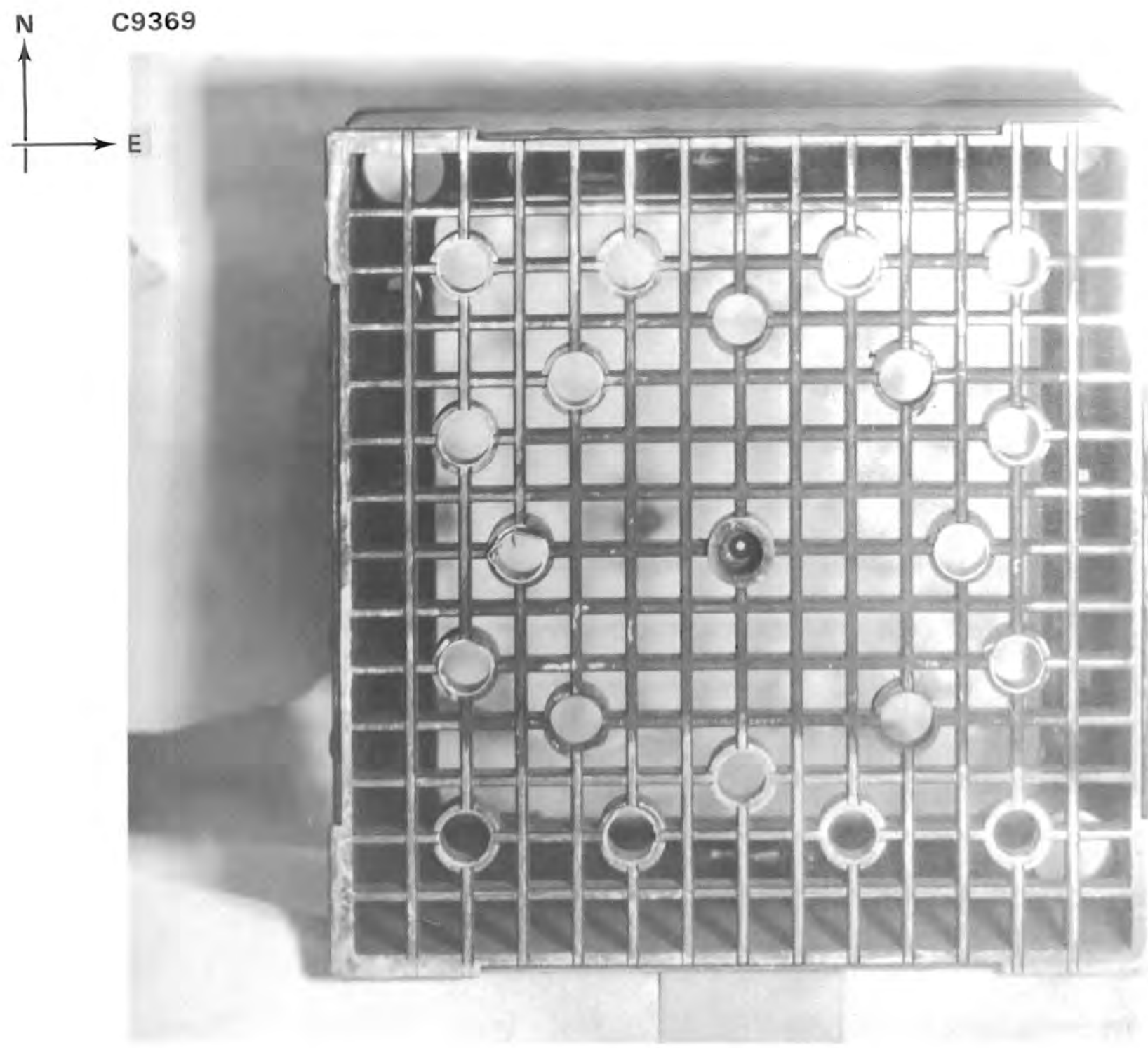

FIGURE 15b. Bottom View of Top Nozzle

indicated that surface deposits were very thin. The fuel rod end cap welds showed no indication of exterior corrosion either in the visual examinations (Figure 16) or in the metallographic examinations (Figure 17). Axial scratches, attributed to abrasion at spacer contacts, were observed when the fuel rods were inserted into or removed from the assembly, and some shallow indentations at cladding-grid spacer spring contact were noted (see Figures 16 and 18). None of the anomalies observed during the underwater per iscope examination were discernible. The fuel rods were dry during the visual 


\section{HC8499}

$\underset{\omega}{\omega}$

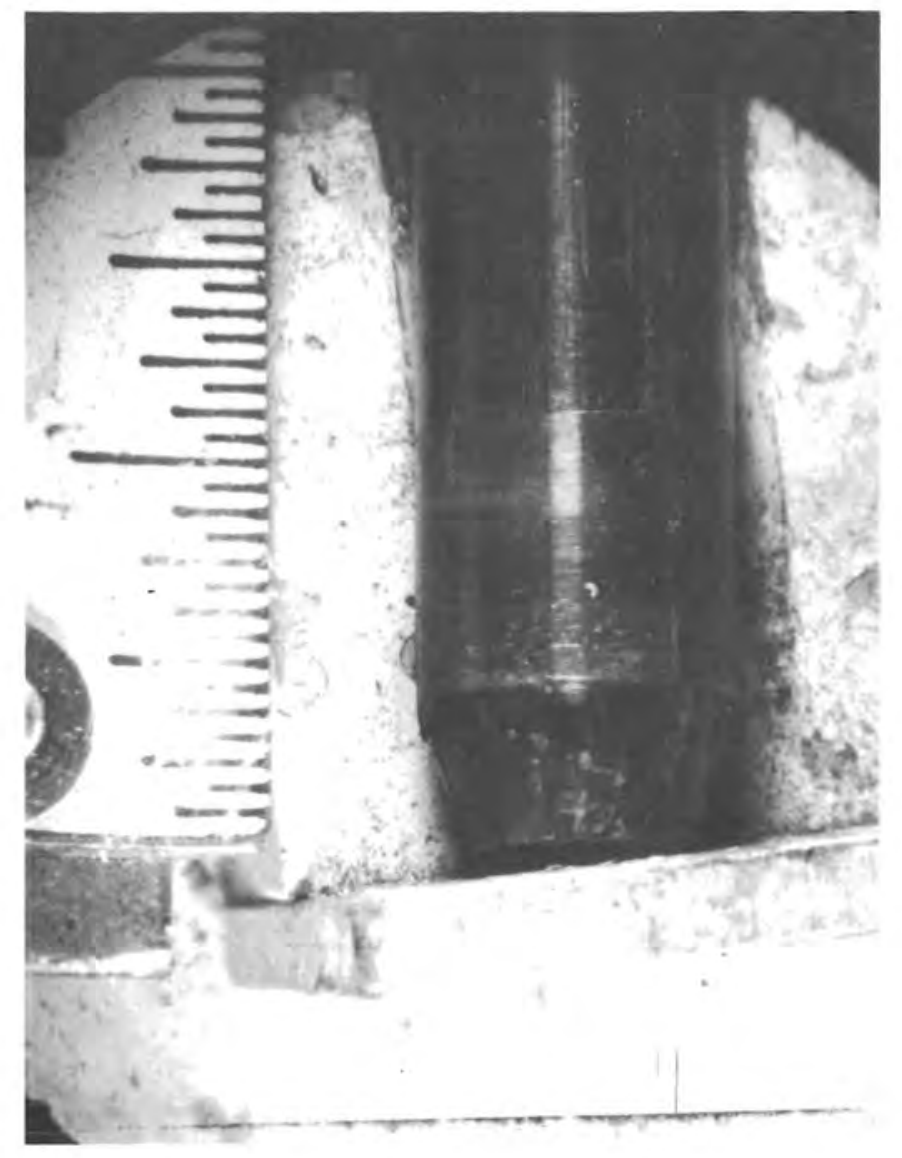

(a) Upper

\section{HC8485}

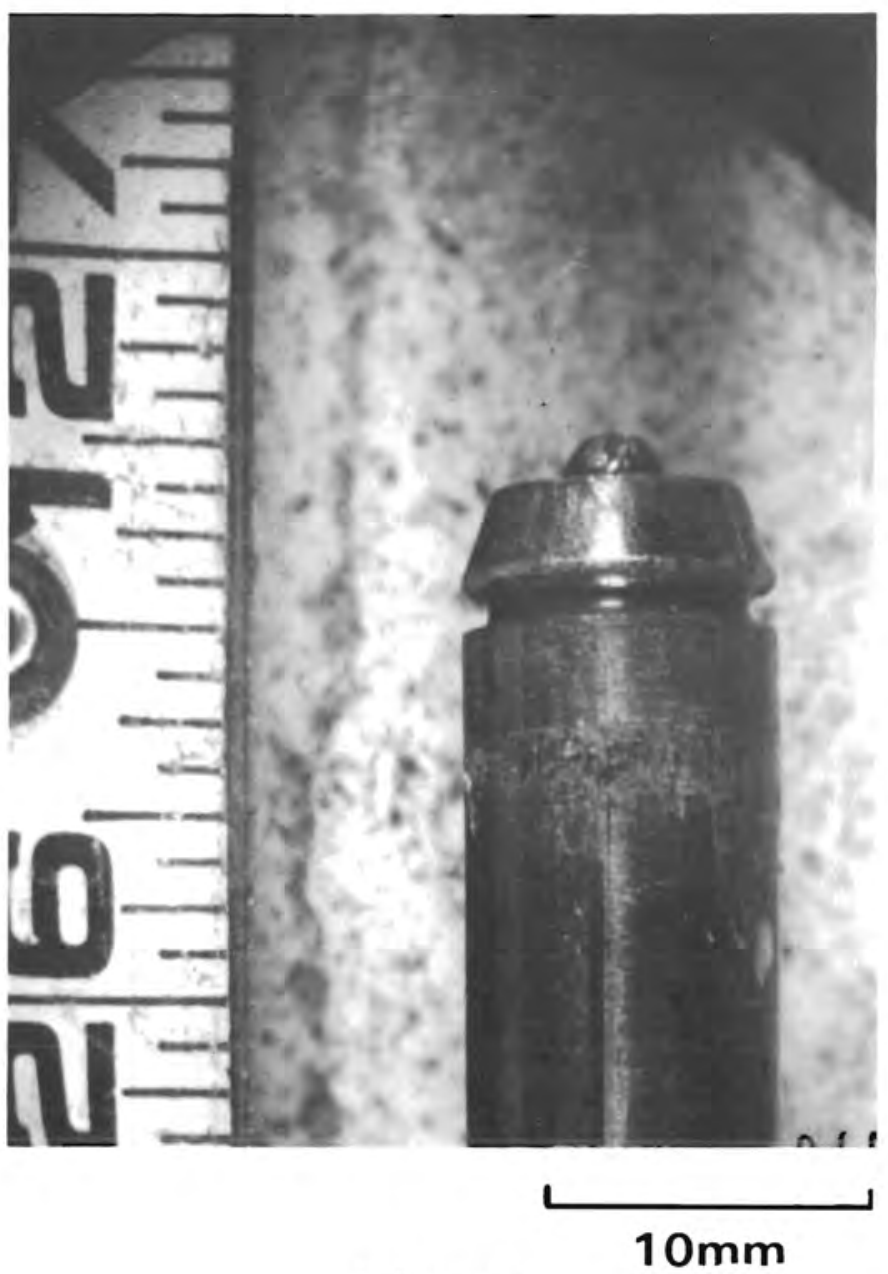

(b) Lower

FIGURE 16. Upper and Lower End Caps and End Cap Weld Areas from S004 Fuel Rods Showing the Machined Area at the Lower End Cap and Handling Marks 


\section{HC50135}

\section{CLADDING}

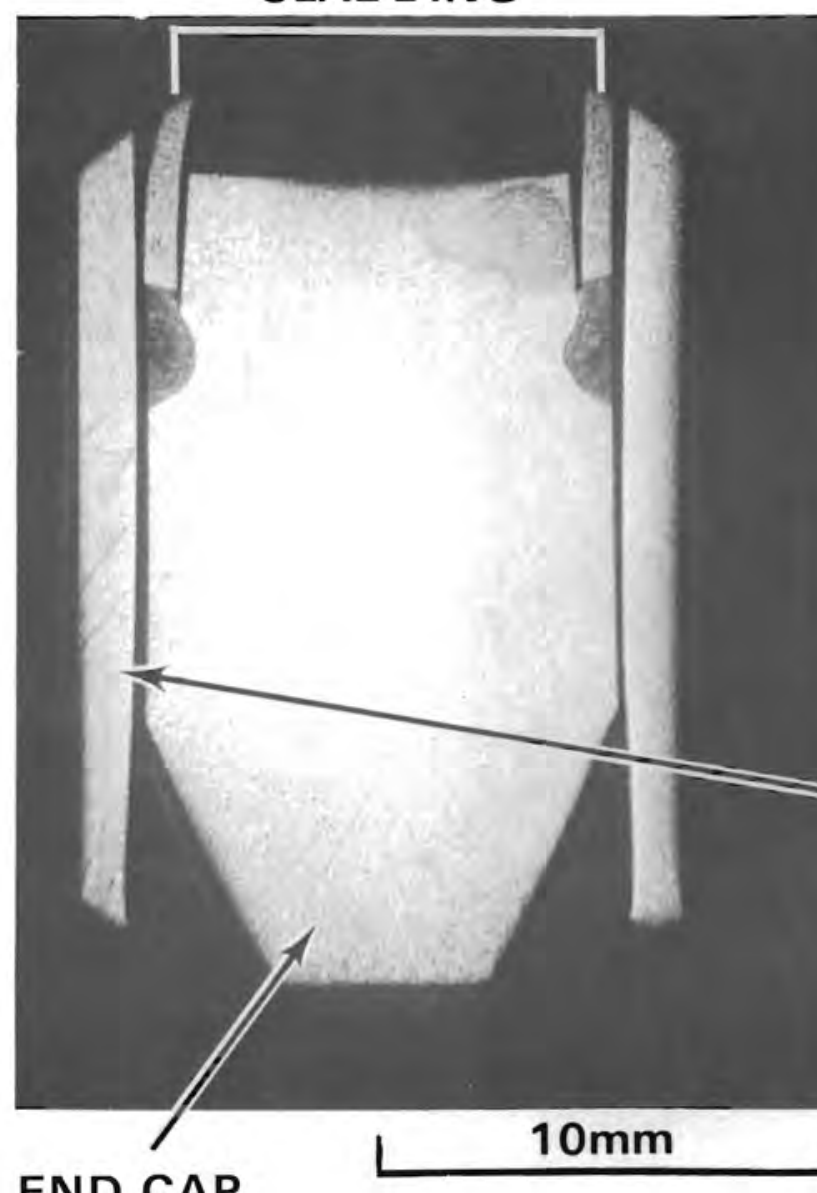

HC50136

\section{CLADDING}

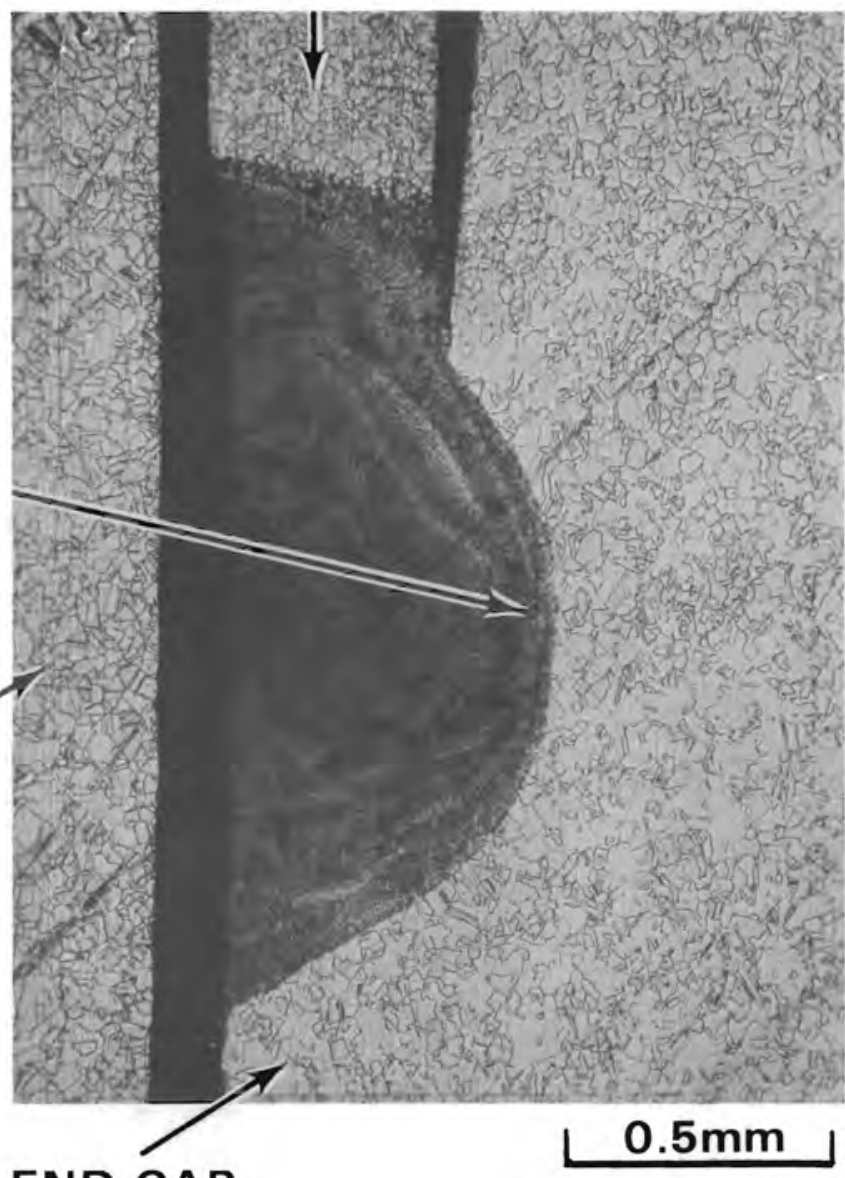

FIGURE 17. Metallography of Longitudinal Section of Lower End Cap Weld from a Stainless SteelClad Fuel Rod from SOO4 


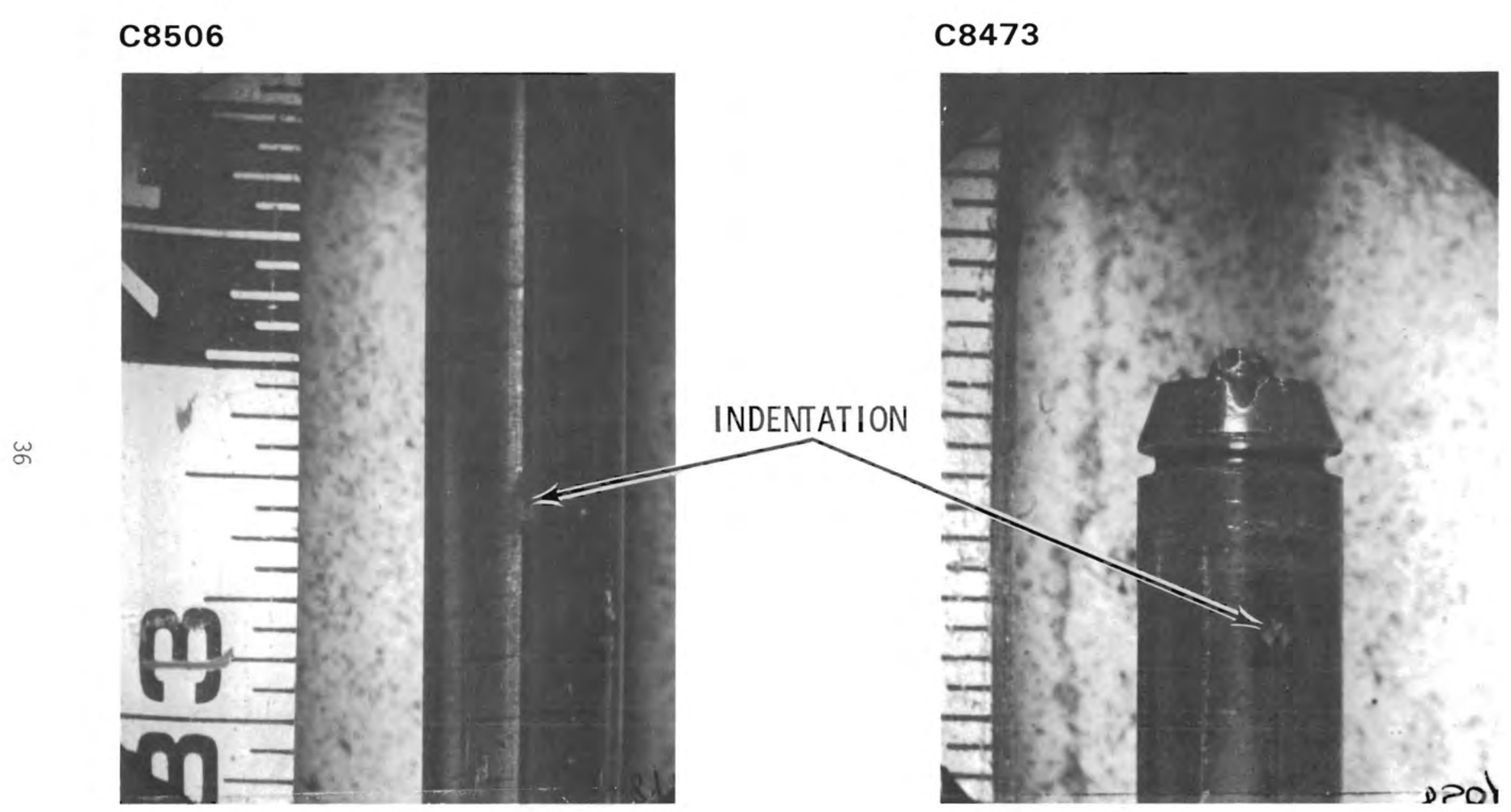

FIGURE 18. Shallow Indentation on Cladding at Grid Spacer Contact Point That was Observed During Visual Examination 
examination. Possibly, drying of the cladding surface altered the appearance of stains that were evident under wet conditions. If the black spot was a crud deposit, it may have spalled from the surface when the cladding warmed during transport. If the black spot was a hole that was $1 / 8 \mathrm{in.}(3 \mathrm{~mm})$ in diameter, it would have been seen during visual examination. No defects were observed in either this rod or the other seven visually examined rods.

Videotapes (black and white) showed dull areas, which ranged from gray to black on the otherwise shiny cladding surface. Several rods were shiny at grid spacer locations. Rod AGR was a particularly striking example where the cladding appeared shiny under grid spacers, became duller moving up the rod, and became dark as each grid spacer was approached. This phenomenon was most apparent between the $106.7 \mathrm{~cm}$ (42 in.) location and the upper end cap. A similar phenomenon (Figure 19) was observed in an EPRI review of waterside corrosion behavior of PWR, Zircaloy-clad fuel rods (Garzarolli et al. 1980). In this case, the thickness of an oxide layer was changing in the same manner as the apparent, albeit much thinner, layer on the stainless-clad 5004 rod. Further discussion of cladding surface layers appears in the section on metallography.

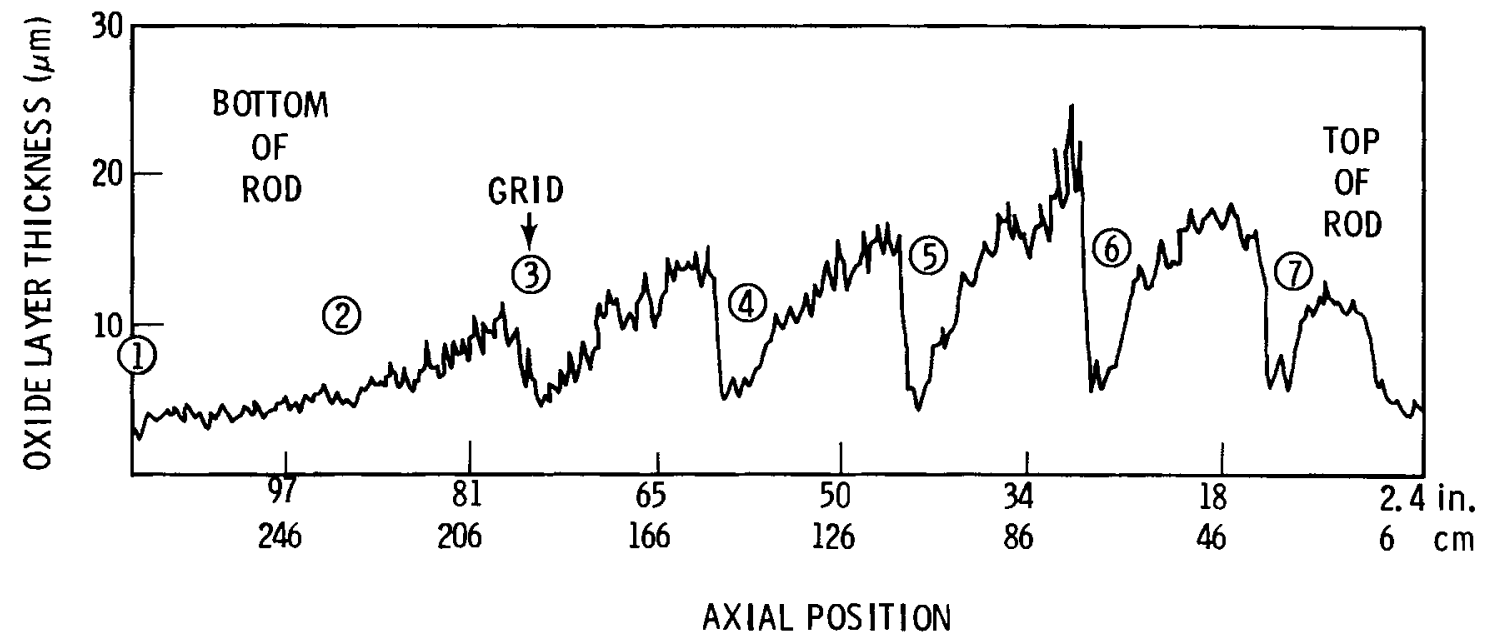

FIGURE 19. Oxide Layer Thickness Trace (from Garzarolli et al. 1980) Similar to the Change in Appearance in the Axial Direction Along S004 Fuel Rod AGR 
Rod Weights

Fuel rod weights were measured to establish a basis of comparison for measurements taken during later examinations. Water ingress during operation or storage might have been suggested if measurements had shown a weight increase. No significant increase in rod weight occurred in the precharacterized rods that were measured.

Rod weights were measured at BCL with an $11.35-\mathrm{kg}(25-1 \mathrm{~b})$ load cell and a Model 1200 strain indicator. Instrument zero and calibration were checked after each rod weighing. Table 13 summarizes the results of the rod weighings.

Five of the eight rods weighed at BCL were precharacterized by BNFL. During the precharacterization, the fuel stack weights were recorded but not the total fabricated rod weight. Consequently, a direct comparison of the weights from the precharacterization with the weights from BCL cannot be made. However, a statistical analysis can be used to indirectly compare the weights. Table 14 summarizes the fuel rod weight statistics for the S004 rods.

TABLE 13. Fuel Rod Weight Data for Assembly SOO4

\begin{tabular}{|c|c|c|c|c|}
\hline $\begin{array}{c}\text { Rod } \\
\text { Designation } \\
\end{array}$ & $\begin{array}{c}\text { Rod } \\
\text { Location } \\
\end{array}$ & $\begin{array}{l}\text { Rod Weight }(\mathrm{a}) \\
\text { Total }(\mathrm{g}) \\
\end{array}$ & $\begin{array}{l}\text { Fuel Stack (b) } \\
\text { Weight (g) }\end{array}$ & $\begin{array}{l}\text { Rod Weight } \\
\text { Fue 1 Weight } \\
(\mathrm{g})\end{array}$ \\
\hline $\mathrm{AHL}(\mathrm{c})$ & R15 & 2660.0 & 2262.0 & 398.0 \\
\hline $\operatorname{AGR}(c)$ & Ro9 & 2660.0 & 2264.0 & 396.0 \\
\hline ALF & P07 & 2663.0 & -- & -- \\
\hline$A B G(c)$ & R01 & 2665.0 & 2264.0 & 401.0 \\
\hline $\operatorname{AHR}(\mathrm{c})$ & $\mathrm{F} 12$ & 2660.0 & 2258.0 & 402.0 \\
\hline$A J Q$ & $\mathrm{~K} 12$ & 2665.0 & -- & -- \\
\hline $\operatorname{AEK}(\mathrm{c})$ & F04 & 2685.0 & 2280.0 & 405.0 \\
\hline AAP & G03 & 2660.0 & -- & -- \\
\hline
\end{tabular}
(a) Measured at BCL.
(b) Measured at BNFL.
(c) Rods precharacterized at BNFL. 
TABLE 14. Fuel Rod Weight Statistics for Assembly S004

\begin{tabular}{|c|c|c|c|c|c|}
\hline & Number & & & $\begin{array}{r}\text { Standard } \\
\text { One } \\
\end{array}$ & $\begin{array}{l}\text { eviation, } \\
\text { Sigma } \\
\end{array}$ \\
\hline & of Rods & Include AEK & Exclude AEK & Include AEK & Exclude AEK \\
\hline Rod Weight (a) & 8 & 2665.0 & & 8.5 & \\
\hline Rod Weight (b) & $\begin{array}{l}7 \\
5\end{array}$ & 2666.0 & 2662.0 & 10.8 & 2.4 \\
\hline & 4 & & 2661.0 & & 2.5 \\
\hline $\begin{array}{l}\text { Fuel Stack } \\
\text { Weight (b) }\end{array}$ & $\begin{array}{l}5 \\
4\end{array}$ & 2266.0 & 2662.0 & 8.4 & 28 \\
\hline (BCL-BNFL) & 5 & 400.0 & & 3.5 & \\
\hline Weight (b) & 4 & & 399.0 & & 2.8 \\
\hline $\begin{array}{l}\text { Stack Weight } \\
\text { Fabrication } \\
\text { Specification }\end{array}$ & & & 2264.0 & & 6.0 \\
\hline
\end{tabular}

(a) Rods AHL, AGR, ALF, ABG, AHR, AJQ, AEK, and AAP (see Table 13).

(b) Rods AHL, AGR, ABG, AHR, and AEK (see Table 13).

Possible contributors to rod weight change other than water ingress were considered. For example, corrosion could contribute from 4 to $10 \mathrm{~g}$ of weight loss for these rods using calculated values based on corrosion rates of $10 \mathrm{~g} / \mathrm{dm}^{2}$-mo and $26 \mathrm{~g} / \mathrm{dm}^{2}$-mo for 304 stainless steel in a high-temperature irradiation environment typical of a PWR (Johnson 1975). The weight 1oss/gain occurring in the storage pool would be less because of the lower temperatures involved.

A statistical approach can be used to develop a statement on the occurrence of a significant weight change (i.e., the weight increase expected in the case of a breached fue 1 rod that had become waterlogged). For instance, Rod AEK is significantly heavier than the average weight of the other rods (i.e., $2685 \mathrm{cf} 2662 \mathrm{~g}$, a difference of $23 \mathrm{~g}$, which is equivalent to the weight of $23 \mathrm{~cm}^{3}$ of water). The measured void volume of rods from 5004 is about $22 \mathrm{~cm}^{3}$. But does a rod weight of $2685 \mathrm{~g}$ constitute a weight gain? The standard deviations for the rod and fuel stack weights were comparable, which implied that the variation in weights measured at $B C L$ and BNFL were comparable. 
An assumption made at this point is that whatever weight changes occur in sound rods occur uniformly in each rod. To look at those changes, the difference between the rod and fuel stack weights was determined, as well as the average and standard deviation of those values. The one-sigma value was $3.5 \mathrm{~g}$, a number probably consistent with the normal variation in hardware weight for these rods. The rods were relatively clean; oxide, crud, and other debris did not contribute significantly to the measured weights.

The standard deviations were again calculated for rod and fuel stack weights and for the rod and stack weight difference excluding the weights for rod AEK. These values are all comparable at about $3 \mathrm{~g}$, which compares well with the $3.5 \mathrm{~g}$ standard deviation originally calculated for the value of the difference between rod and fuel stack weights. The weight data indicate that whatever weight changes did occur were uniform from rod to rod. Based on the other results from this examination, these weight measurements support the contention that there has been no cladding breach followed by water ingress in these rods. The total rod weights now recorded will make evaluation of future rod weight measurements more straightforward.

The weight change of rod AEK is greater ( $\sim 2 \mathrm{~g})$ than the standard deviation determined for the other rods. In lieu of additional hardware or as-fabricated rod weight information, the rods weighed do not appear to have significantly changed in weight.

\section{Profilometry Measurements}

Spiral profilometry traces were made on the outside surface of each fuel rod to characterize diameter changes that occurred during irradiation. No extraordinary features were observed in the rod profilometry traces. Profilometry can also detect significant localized cladding anomalies such as ovality and ridging. Linear (axial) profilometry traces were made in cases where additional dimensional detail was required.

Before and after profiling the rods, the system was calibrated with the BCL No. 4 Profilometry Standard which contains the following diameters: $0.413140,0.418120,0.422180,0.426110$ and $0.431070 \pm 0.000025$ in. The standard was measured in the BCL Standards Laboratory against a standard traceable to the National Bureau of Standards. 
The mean diameter in any given rod segment is defined as the average of the maximum and minimum diameter at any axial location along the rod. Rod ovality is defined as the difference between the maximum and minimum rod diameter at a given axial location. A drive pitch of $1 / 8$ in. per revolution was used for the measurements. The accuracy and precision of diametral measurements was +0.0002 in. $(0.0005 \mathrm{~cm})$ at the $95 \%$ confidence level. The system is capable of determining the axial rod location to within $\pm 1 / 16 \mathrm{in}$. (1.6 mm). The rods were rotated at a lower than normal speed during spiral profilometry because the recorder response was not rapid enough to follow the change in rod diameter at the normal speed (i.e., because of the high cladding ovality).

Spiral profilometry was completed on the lower $40 \mathrm{in} .(102 \mathrm{~cm})$ of the corner rods $A D U$ and $A C H$ after full length traces on $A B G$ and $A H L$ failed to show any features that could be correlated with the "bulge" observed in the preshipment visual examination (Figure 20). Strong node-like areas did occur in the fifth span area in the trace from ADU (see Figure 12 for span location). Generally, the traces for these rods were characteristic of the spiral profilometry typi$\mathrm{cal}$ of rods from $\mathrm{SOO}$.

Spiral profilometry results from assembly $\mathrm{SOO4}$ rods indicated that cladding ovality was typically 0.30 to $0.36 \mathrm{~mm}$ (12 to $14 \mathrm{mils}$ ) in the upper and lower regions of the rods, ranging to a maximum of about $0.46 \mathrm{~mm}$ (18 $\mathrm{mils})$. (a) Ovality was less in the center region of the rods. Cladding creep-down was up to $0.025 \mathrm{~mm}$ ( $1 \mathrm{mil}$ ) on the lower burnup rod and up to $0.038 \mathrm{~mm}(1-1 / 2 \mathrm{mil})$ on the high burnup rod (Figure 21). Most of the creep-down occurred in the upper half of the rods. No obvious indications of cladding defects were observed in any of the profilometry traces.

Linear (axial) profilometry traces were run at $0^{\circ}, 45^{\circ}, 90^{\circ}$, and $135^{\circ}$ orientations on the high burnup rod (AHR) in the region of the eddy current indication and in the $0^{\circ}$ orientation over the full rod length. Helical variations

(a) This is in sharp contrast to the ovality noted in fuel rods from assemblies G11 and H07 (Pasupathi and Klingensmith 1981). In G11 and H07 rods, the ovality was rather low (less than $0.10 \mathrm{~mm}$ or $0.004 \mathrm{in.}$ ). The nominal diametral gap (i.e., cladding ID minus pellet diameter) for S004, GIl, and HO7 fuel rods was $0.14 \mathrm{~mm}(0.0055 \mathrm{in.})$. S004 fuel densified about the same amount as G11 fuel but swelled at a lower rate. 


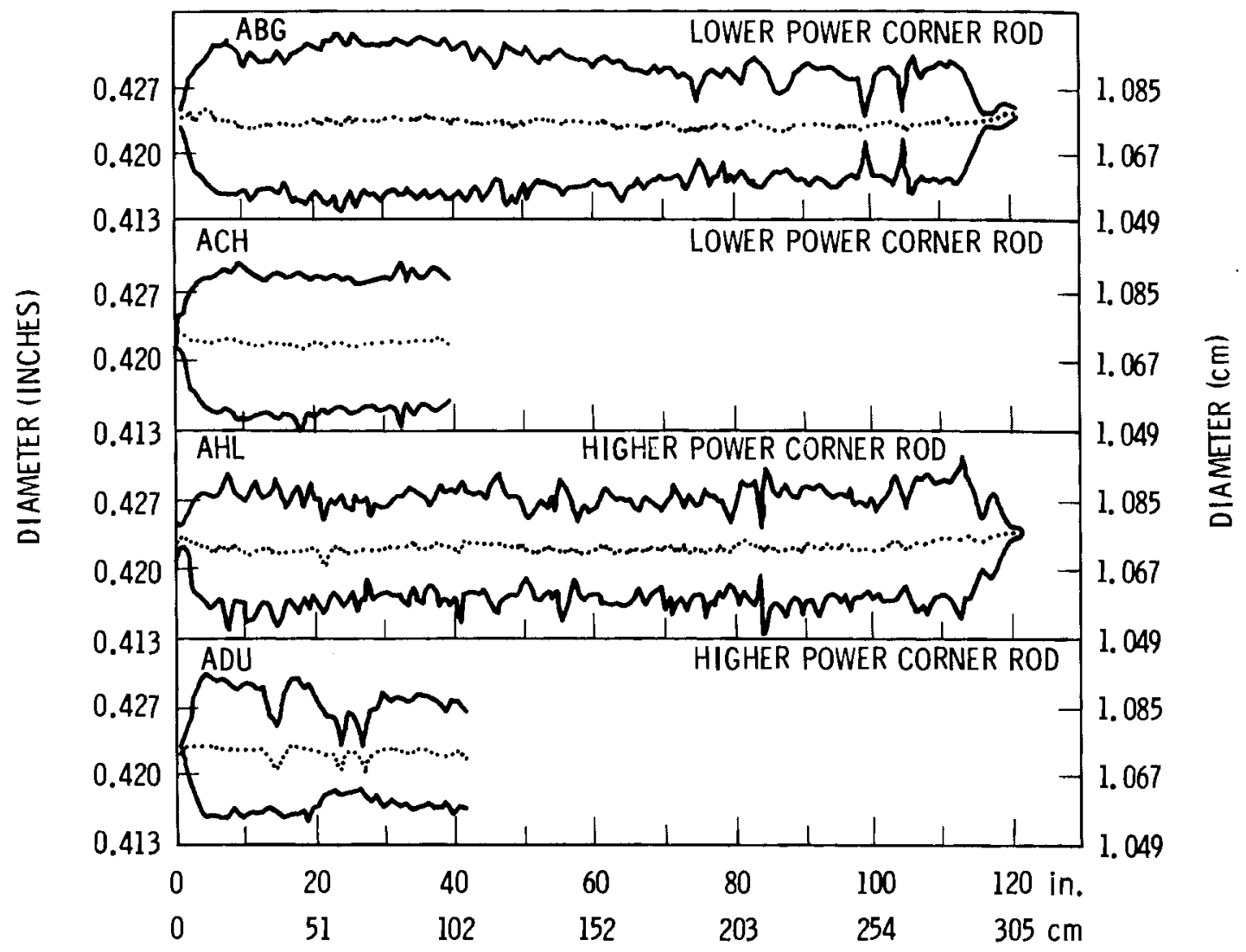

AXIAL DISTANCE (DISTANCE FROM BOTTOM OF ROD)

FIGURE 20. Spiral Profilometry Data for Corner Rods ABG, ACH, AHL, and ADU from Assembly S004 Showing the Envelope of Maximum and Minimum Cladding Diameters Along the Rod Axis. (Only the bottom portions of Rods ACH and ADU were measured. Note similarity of profiles of rods from symmetrical power/burnup positions within the assembly, i.e., $A B G / A C H$ and AHL/ADU.)

in the cladding ovality were observed when comparing the traces of the spiral and linear profilometry scans for rod AHR in the fourth span (Figure 22). The change in orientation of the cladding ovality over the length of the rod is difficult to determine from the spiral profilometry without the corresponding linear trace.

The "bulge" suggested in the poolside examination now appears to have been an optical illusion. The impression of a bulge in the cladding could result if a cladding section with high ovality disposed helically along the 

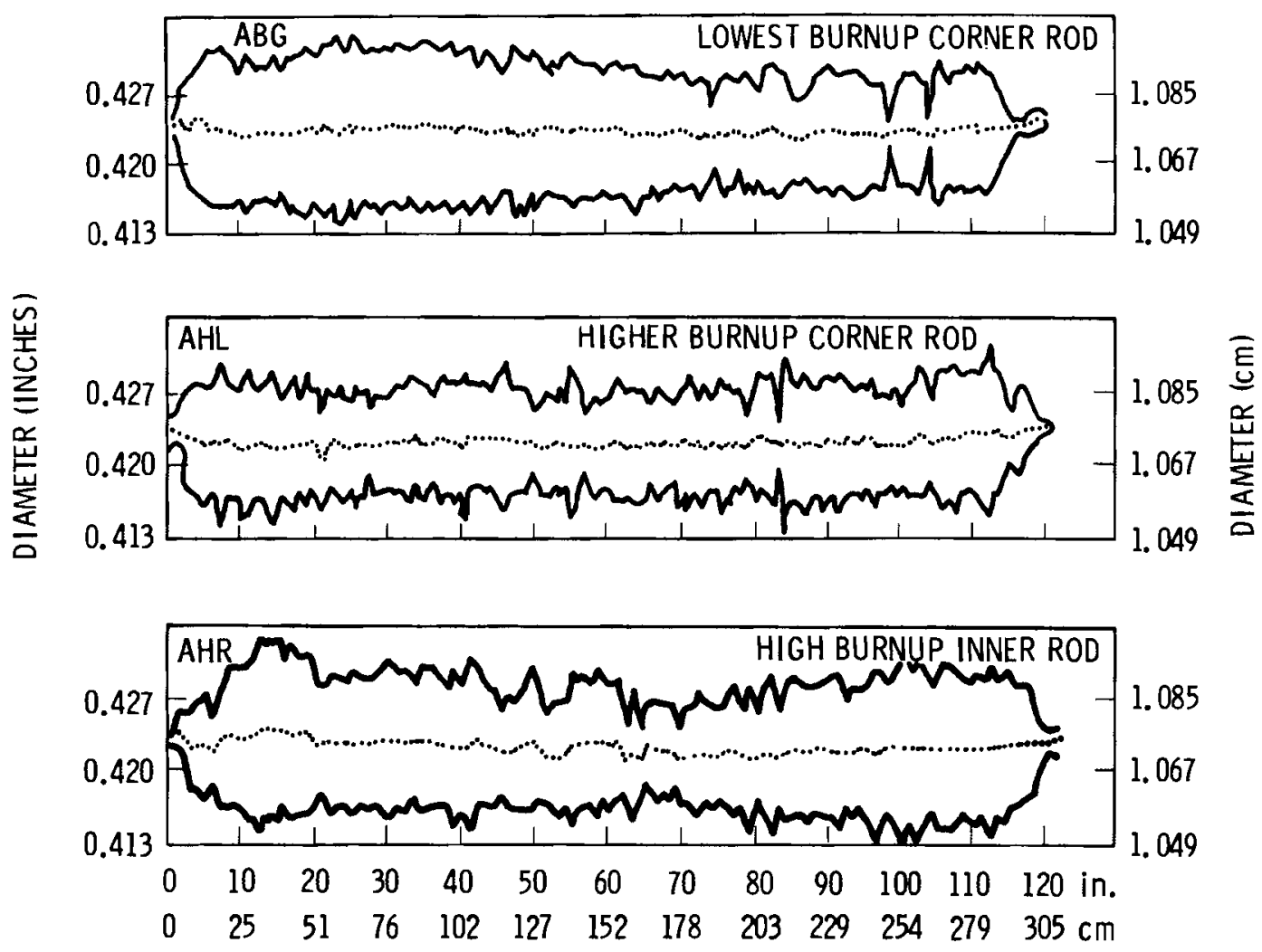

AXIAL DISTANCE (DISTANCE FROM BOTTOM OF ROD)

FIGURE 21. Spiral Profilometry Data for Rods $A B G, A H L$, and AHR from Assembly S004 Showing the Envelope of Maximum and Min imum Cladding Diameters and the Mean Cladding Diameter Along the Rod Length

rod axis is viewed from a point where the maximum cladding diameter is perpendicular to the line of sight and then rapidly changes orientation above and below the apparent maximum. However, the cladding profilometry has shown no bulges. Also, the dimensional envelopes of each of the four corner rods in S004 do not intrude significantly into the coolant channels and do not constitute any operational problem that might be associated with a cladding bulge obstructing the flow of coolant. 


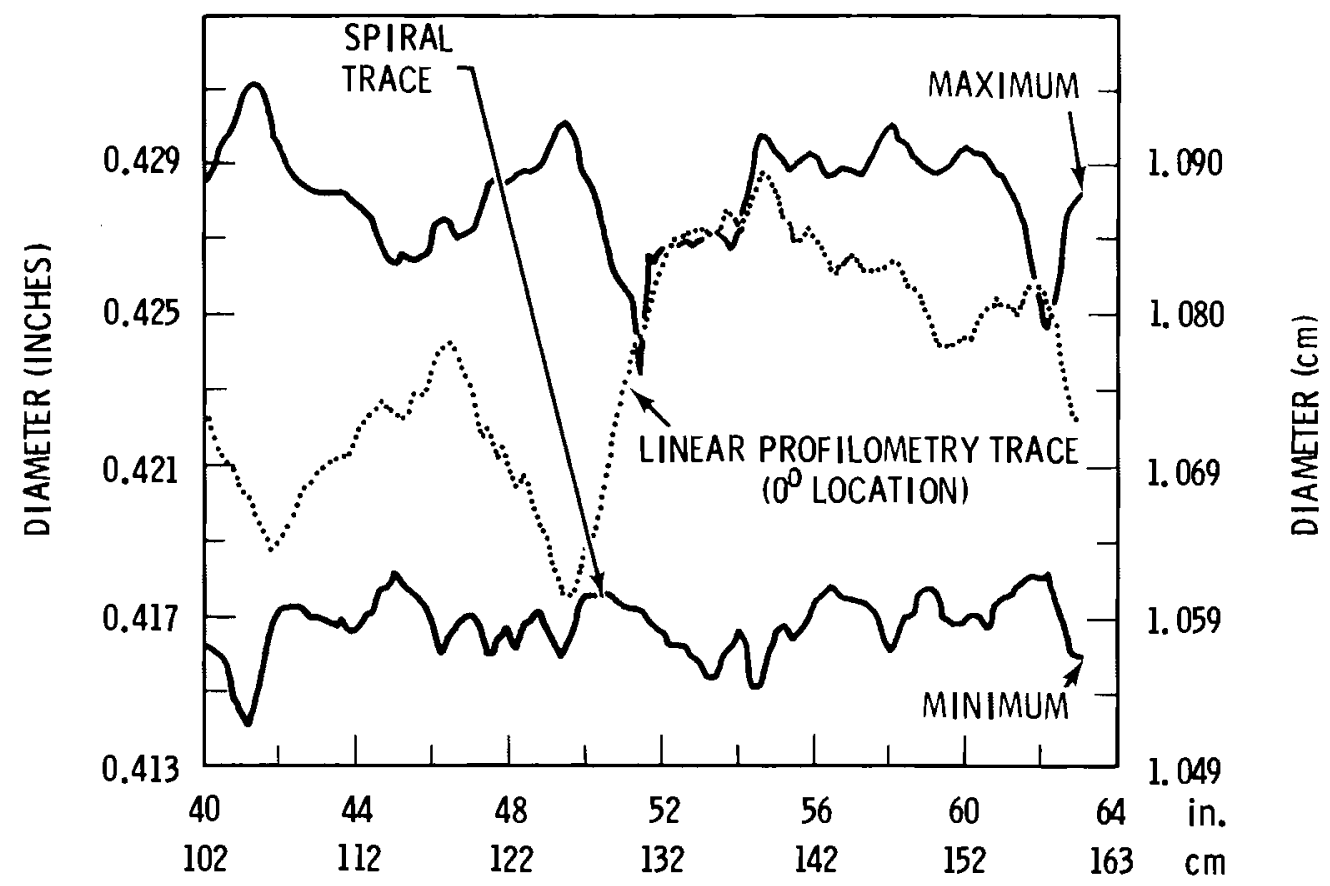

AXIAL DISTANCE (DISTANCE FROM BOTTOM OF ROD)

FIGURE 22. Overlay of Spiral and Linear Profilometry Traces Showing the Precession of Maximum Ovality Around the Axis of Rod AHR

\section{Gamma Scan}

Five rods were gamma scanned along their entire lengths to determine the relative burnup and time-averaged power generation of the fuel. The gamma scans were also used to determine if axial separations between fuel pellets or wide transverse pellet cracks had developed in the fuel column. No unusual axial separations were observed. There was no gross ${ }^{137} \mathrm{Cs}$ axial migration.

Each scan was made by moving the vertically positioned rod at a constant rate of 2 in./min past a collimating slit-detector arrangement and continuously measuring and recording the gamma radiation intensity from the section of the rod passing the collimator. All energies greater than $0.5 \mathrm{MeV}$ were measured with a $\mathrm{Ge}(\mathrm{Li})$ crystal and recorded for the gross gamma scan. A malfunction of the instrument channel which measures the gross gamma radiation resulted in gross gamma measurements being made on only two out of the five rods. The ${ }^{137} \mathrm{Cs}$ isotopic gamma scan measured all energies from 0.63 to $0.68 \mathrm{MeV}$ and was completed for all five rods. Collimators and slits were adjusted to maintain 
a counting rate sufficiently low to avoid dead-time losses. The scanning apparatus was capable of determining the axial rod location to with in $\pm 1 / 32$ in. $(0.0794 \mathrm{~cm})$; the minimum detectable axial gap in the fuel column was 20 mils $(0.0509 \mathrm{~cm})$.

The ${ }^{137}$ Cs isotopic gamma activity traces were used in this investigation because of the correlation of ${ }^{137} \mathrm{Cs}$ activity with fuel burnup reported by others (Phillips et al. 1980). Table 15 lists the fuel stack lengths and the ${ }^{137} \mathrm{Cs}$ activity normalized to the activity of the rod with the highest calculated burnup (rod AHR). Figure 23 shows the normalized value correlated with the calculated rod burnup. The value for average burnup calculated for AHR agreed well with the analytically determined $\left({ }^{148} \mathrm{Nd}\right)$ value of a sample from the high power region from AHR when the calculated average value was multiplied by a 1.2 peaking factor. By normalizing to the analytically determined value of the burnup sample, the burnup of other rods was estimated, thereby improving the confidence in the estimate of the burnup obtained from the physics calculations.

The gamma activity traces clearly showed the pellet-to-pellet interface locations characteristic of fuel columns composed of dished pellets. The pellet interface locations are shown particularly well on the gross gamma scans as well as on the ${ }^{137} \mathrm{Cs}$ isotopic gamma scans (Figure 24). However, the pellet interfaces are not apparent in the high burnup rod (Figure 25) that operated at high power (the higher fuel temperature can result in migration of 137 Cs).

Figure 26 shows the pellet dish area at the 77-in. (196-cm) location on fuel rod 595A10 from G11. Figure 27a shows the gamma scan for the same area. Fuel pellet interfaces are not clearly defined on this trace as they are in the gamma scans of another rod from G11 and one from HO7 (Figures 27b and 27c). Figure 25 shows the gamma scan traces of two corner rods ( $A H L$ and $A B G$ ) from S004, as well as the pellet interface locations. Figure 25 also shows the gamma scan from rod AHR, a high power, high burnup, interior rod from S004. pellet interfaces are much less distinct in this case than in traces of 
TABLE 15. Cesium-137 Gamma Scan Measurements for Selected Fuel Rods from Assembly S004

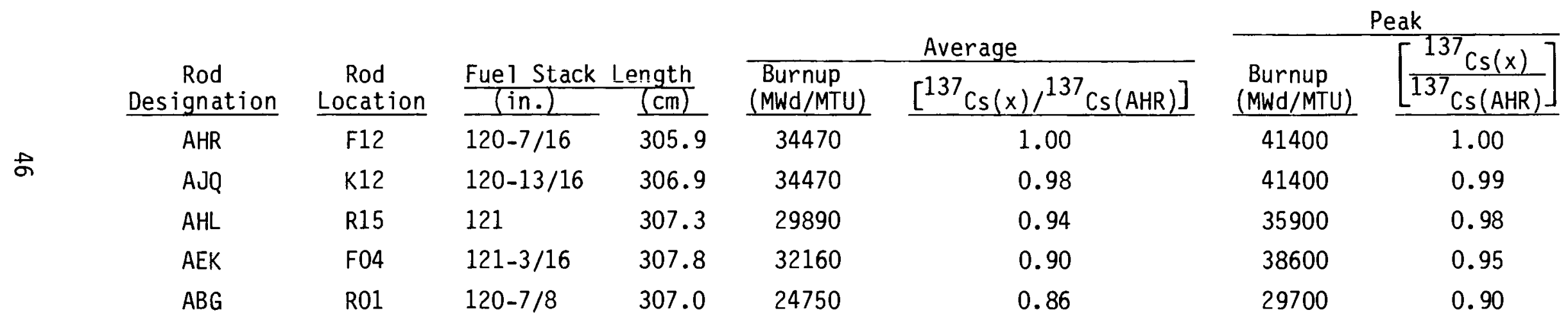




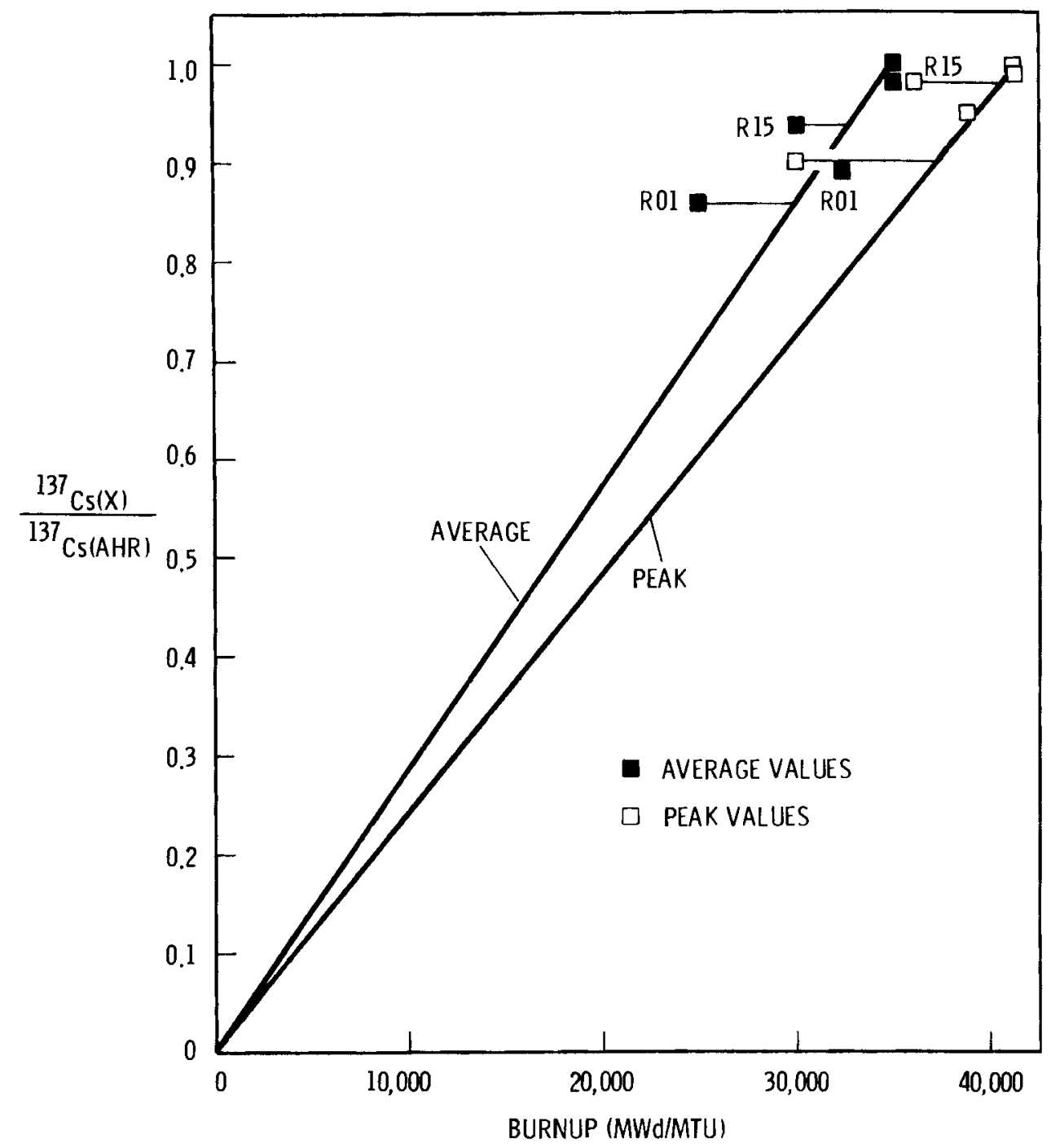

FIGURE 23. Correlation of the Measured ${ }^{137}$ Cs Gamma Activities (Normalized) With the Calculated Burnup Values for Fuel Rods R01 and R15 From Assembly S004

the corner rods. The gamma scan traces for the other interior rods (AEK and AJQ) from assembly 5004 also show indistinct pellet interface locations. Figure 65 (see section on ceramography) is a photograph of the fuel from rod AHR at the 56 in. $(142 \mathrm{~cm})$ location and shows a discontinuous change in fuel grain size across a crack. The temperature increase across the gap is the most likely cause of the grain size increase. This effect is quite common. 


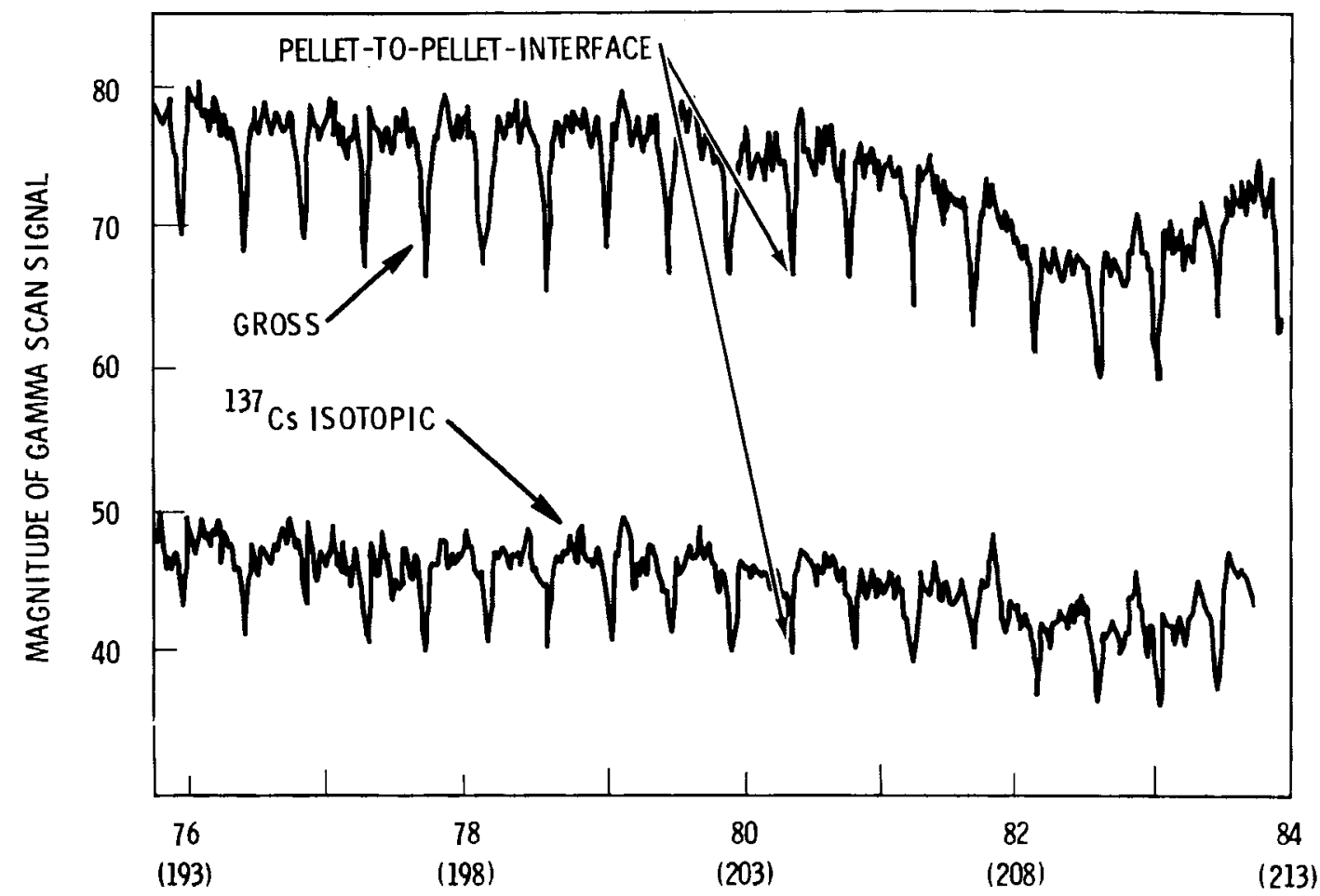

AXIAL LOCATION ABOVE BOTTOM OF FUEL COLUMN, in. $(\mathrm{cm})$

FIGURE 24. Gamma Scan Traces Showing Pellet-to-Pellet Interface Locations in Fuel Column of Rod AHL from Assembly S004

\section{Eddy Current}

An encircling coil was used for the eddy current examinations. No strong indications were observed, although a weak indication was observed at 98.5 in. $(250 \mathrm{~cm}$ ) above the bottom end of the high burnup fuel rod (Figure 28). Subsequent destructive examination revealed no evidence of a defect at that location.

Defect indications from traces of the vertical and horizontal components of the eddy current signal and the differential of the horizontal component are qualitative. An indication suggests the possibility of a cladding defect at a given axial location. 


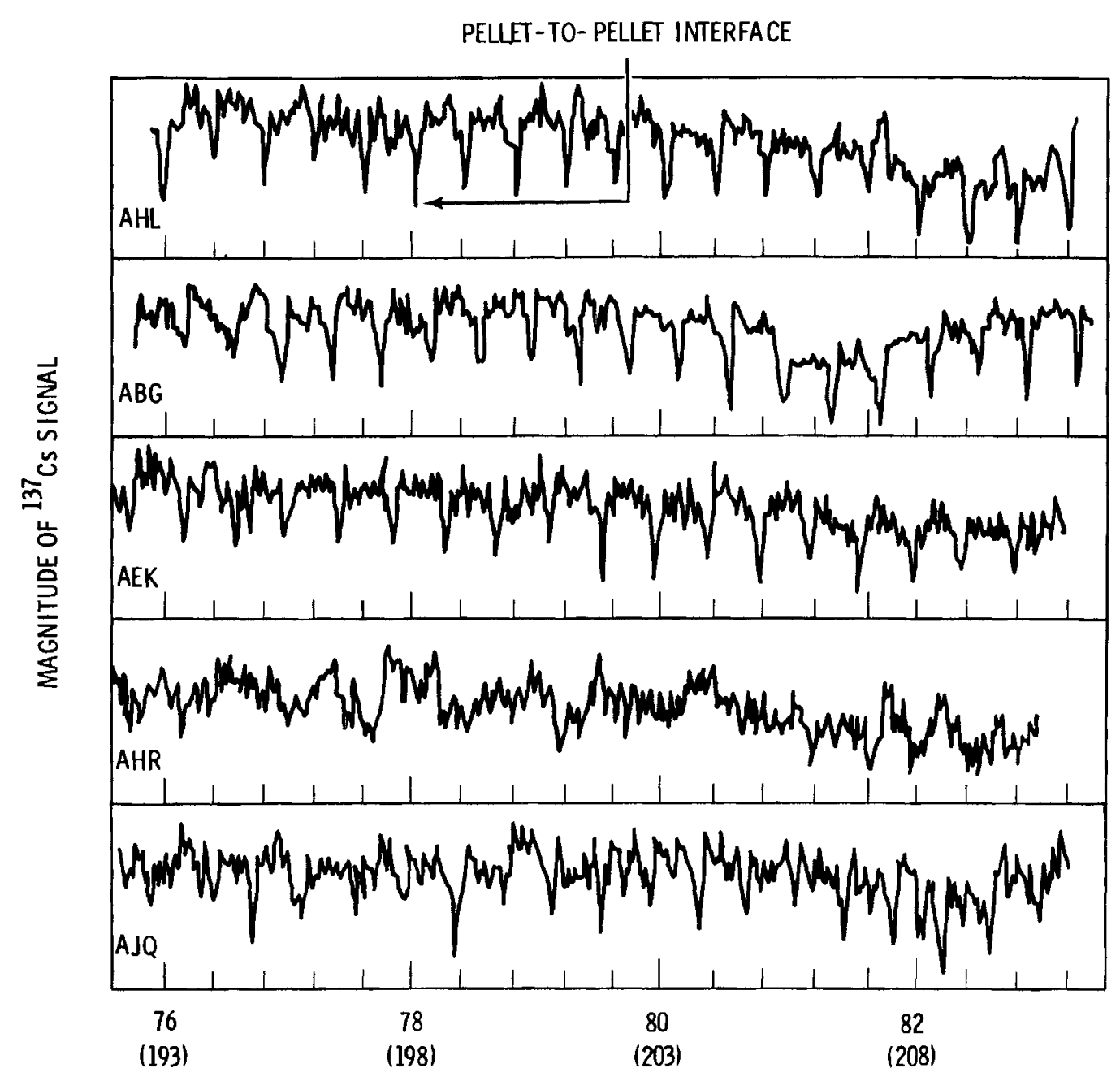

AXIAL LOCATION ABOVE BOTTOM OF FUEL COLUMN, in. (cm)

FIGURE 25. Gamma Scan Traces from Five Fuel Rods from Assembly 5004 Showing the Pellet-to-Pellet Interfaces Distinctly in Lower Power Rods (e.g., $A B G$ ) and Less Distinctly in Higher Power Rods (e.g., AHR)

Temperature

Temperature measurements were made on selected fuel rods because fuel temperature affects rod internal gas pressure calculations and rod dimensional measurements and is used to verify rod decay heat calculations used in fuel storage consideration. The measurements were made to verify that the ambient 


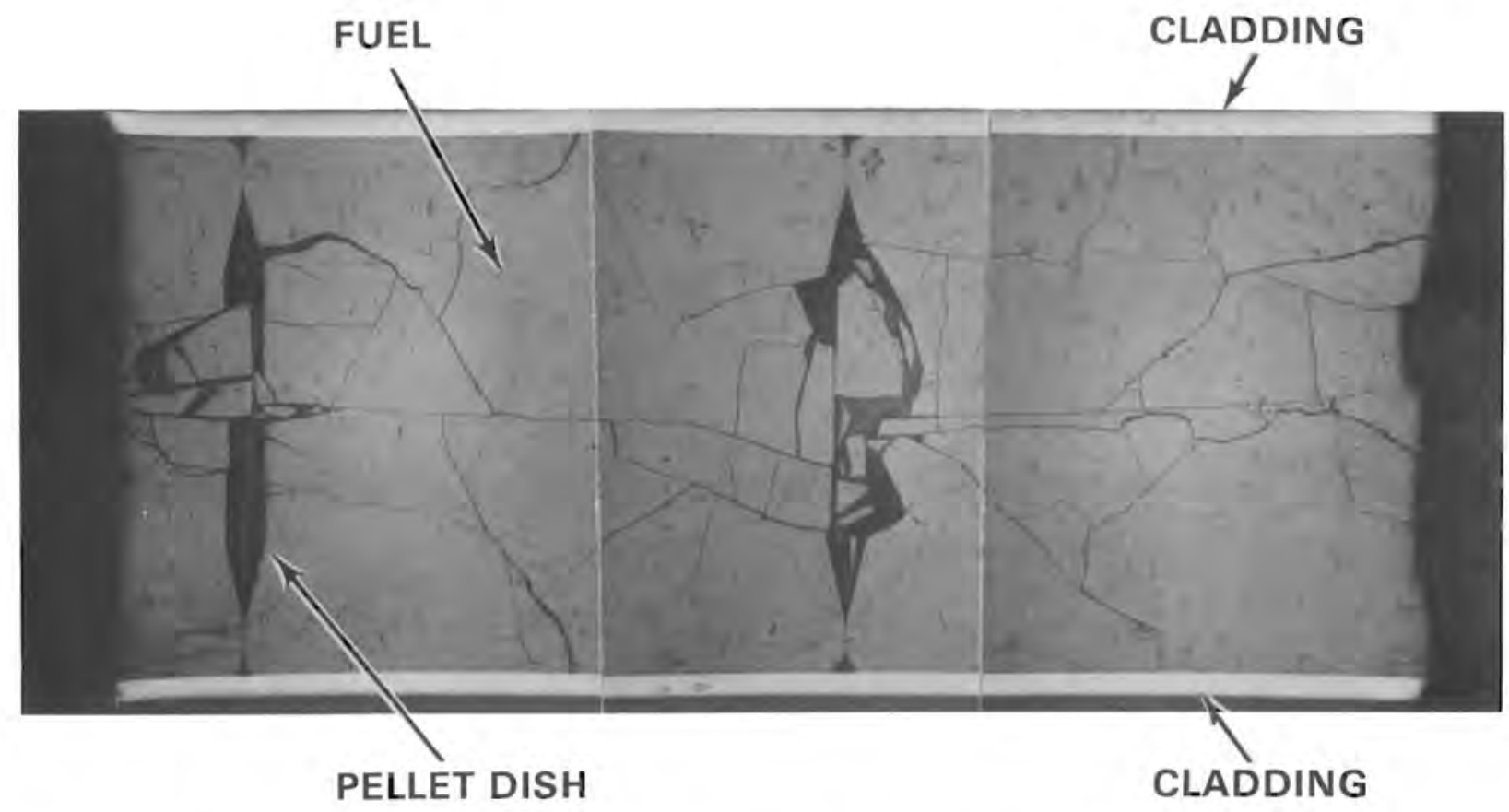

FIGURE 26. Longitudinal Section Showing Pellet Dish Area in Rod 595A10 from Assembly G11 (Figure 33 from Pasupathi and Klingensmith 1981)

cell temperatures would be representative of the gas temperatures in the rods from S004. The results of cladding temperature measurements made on two of the corner rods and four of the interior rods selected for examination are listed in Table 16.

A rod was placed on the visual examination apparatus to prevent heat loss due to contact with a metal surface. The rod was suspended from supports spaced at approximately $30-\mathrm{cm}(1-\mathrm{ft})$ intervals. A probe thermocouple and a Leeds \& Northrup 8690-2 millivolt potentiostat were used for the measurements. Ambient air temperature was checked after each measurement. The results showed good agreement between fuel rod surface temperatures (Table 16) and in-cell ambient temperatures (see Table 17 in subsection on fission gas collection and analysis). 

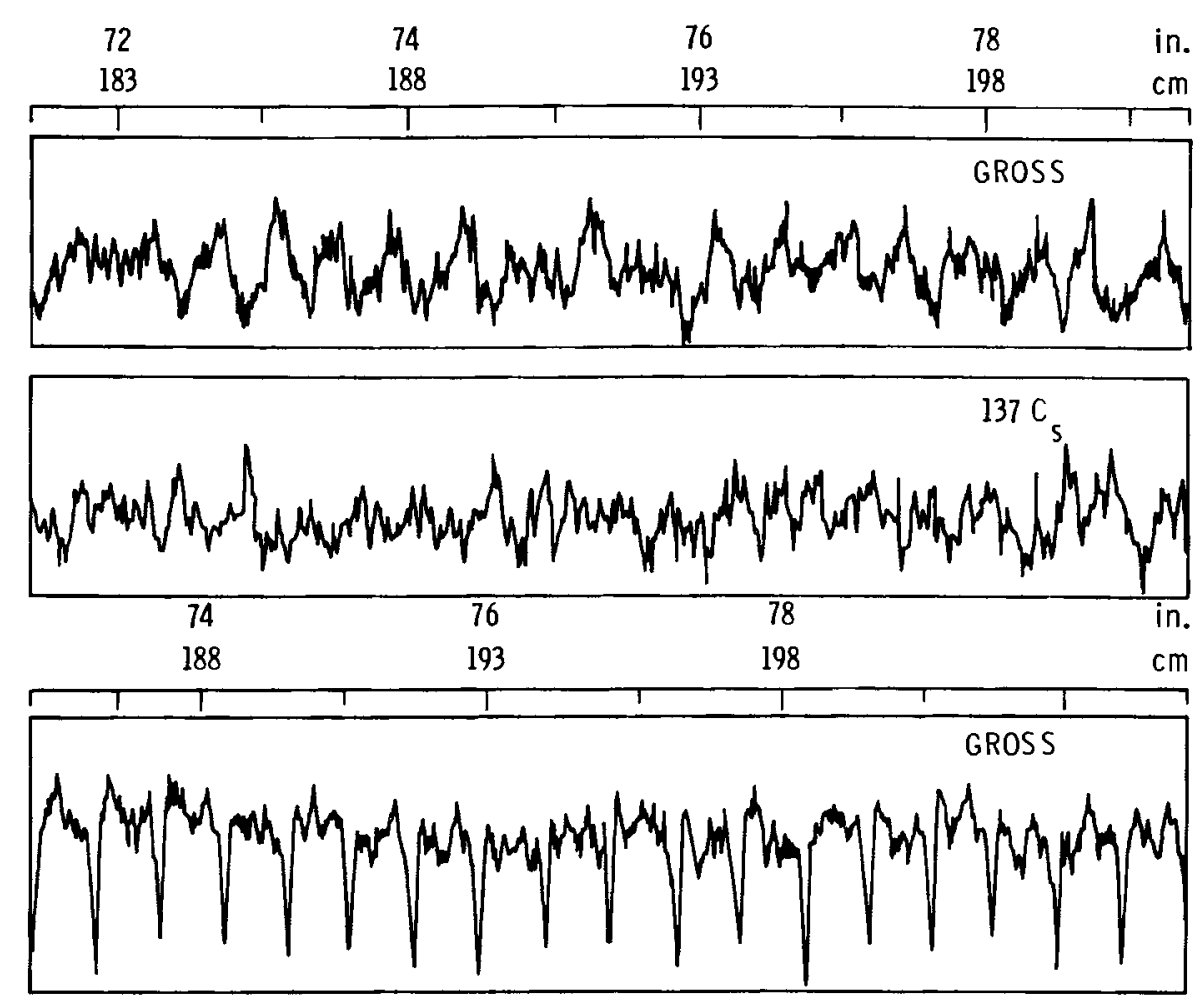

b

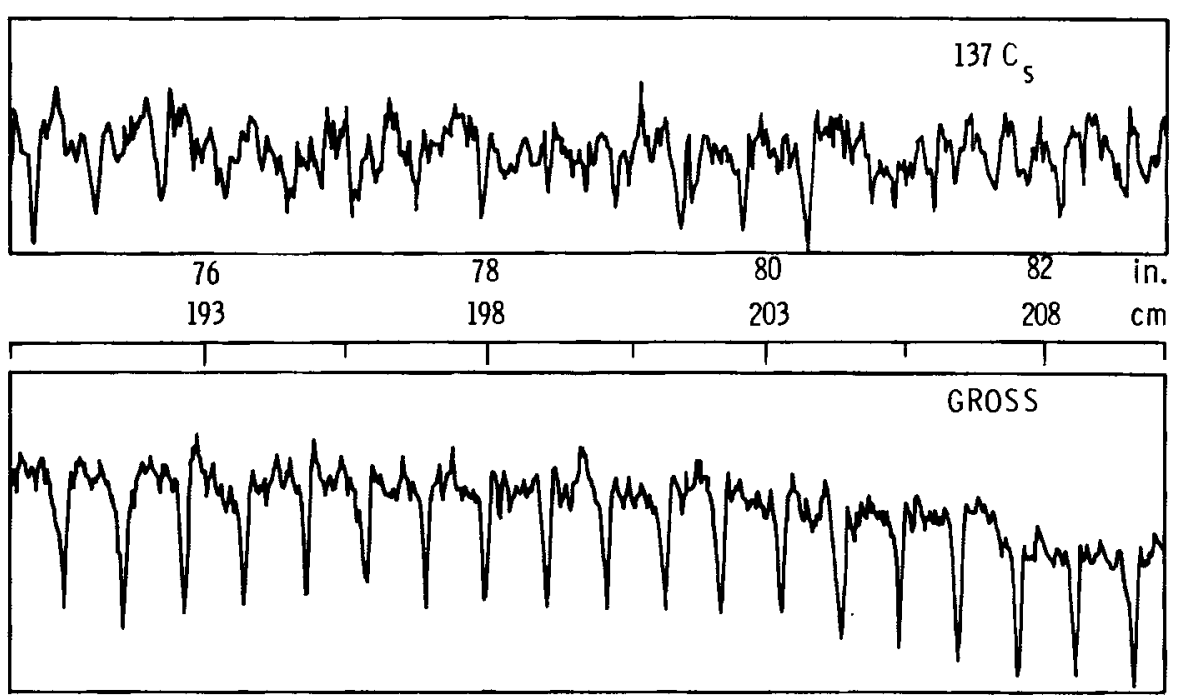

c

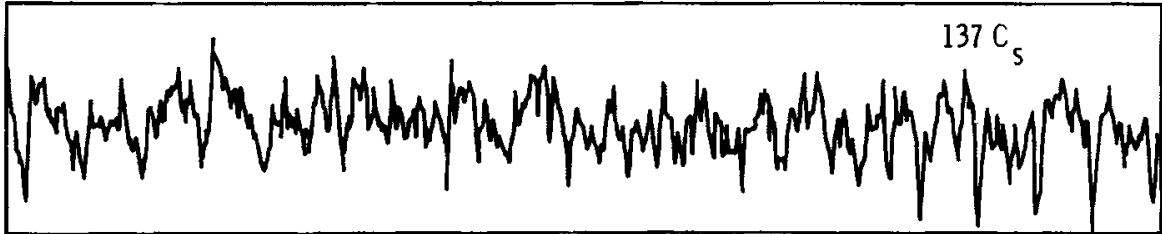

FIGURE 27. Gamma Scan Traces for Selected Fuel Rods from Assemblies G11 and $\mathrm{HO7}$ Showing the Pellet-to-Pellet Interfaces Distinctly in (b) G11 Rod 595A01 and (c) H07 Rod 217E02 and Less

Distinctly in (a) G11 Rod 595A10 


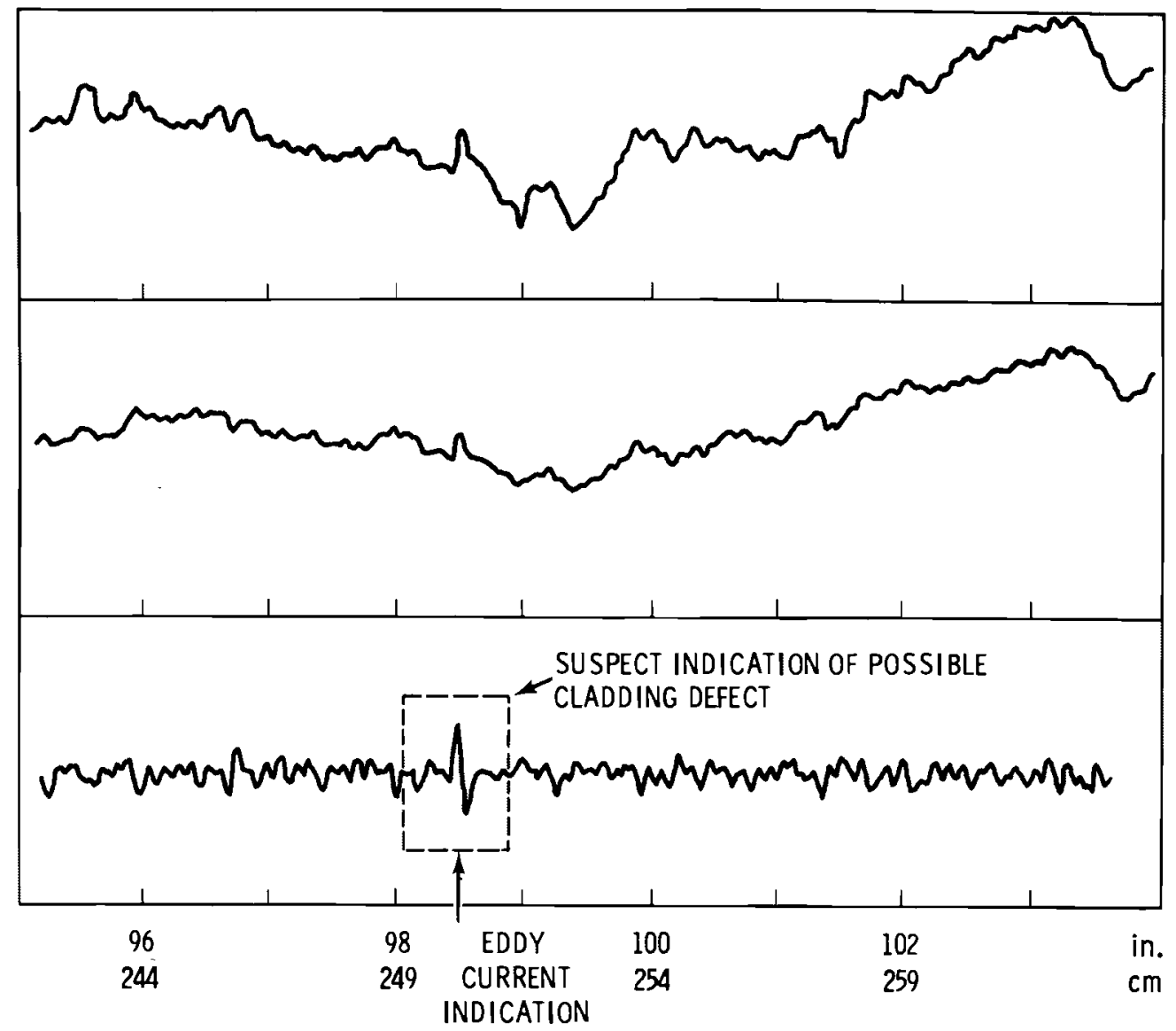

AXIAL LOCATION (DISTANCE ABOVE BOTTOM OF FUEL COLUMN)

FIGURE 28. Eddy Current Traces of Rod AHR from Assembly S004, Showing Typical Traces and the Area Suspected to Contain a Cladding Defect. Subsequent destructive examination revealed no evidence of a defect in that area.

DESTRUCTIVE EXAMINATIONS OF FUEL RODS FROM ASSEMBLY SO04

The objective of the destructive fuel rod examinations was to define the condition of the fuel and the cladding. The examinations and analyses were chosen:

- to determine whether significant cladding or fuel degradation had occurred during reactor residence

- to determine whether significant cladding degradation had occurred during pool residence

- to establish baseline conditions for possible future examinations. 
TABLE 16. Temperature Measurements $\left({ }^{\circ} \mathrm{F}\right)$ for $\mathrm{Cladding}$ on Irradiated Fuel Rods from $\mathrm{SOO} 4$

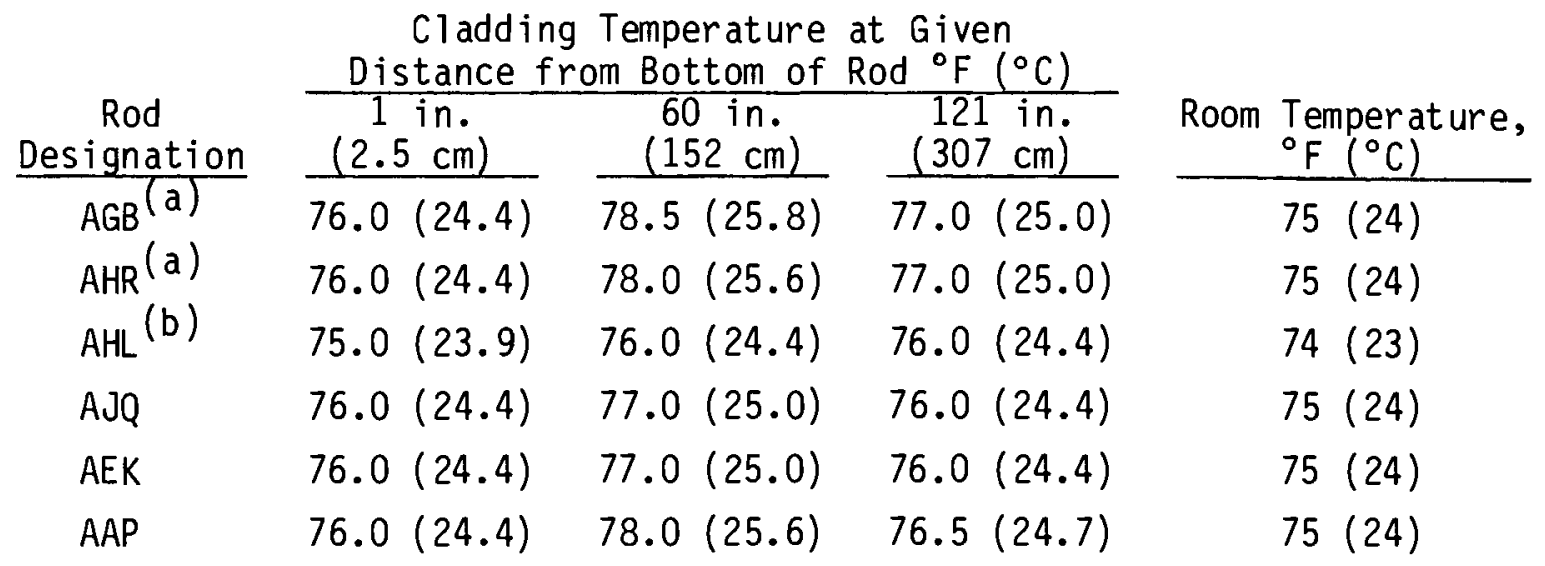

(a) Rod lying in air approximately $1 / 2 \mathrm{hr}$ before temperature measured.

(b) Rod lying in air approximately $1 / 4 \mathrm{hr}$ before temperature measured.

The specific examinations included fission gas collection and analysis, void volume determination, metallographic examination of the fuel and cladding, burnup analysis, autoradiography, fuel density, and cladding mechanical property testing.

Fission Gas Collection and Analysis

The gas inside the fuel rods (fission gas plus helium fill gas) was collected from four S004 rods, three HO7 rods (Pasupathi and Klingensmith 1981) and one ${ }^{(a)}$ G11 rod (Pasupathi and Klingensmith 1981) to determine the fission gas release. For each rod, the rod void volume was measured, the prepuncture rod pressure was calculated, and the collected gas was analyzed. The values for the increase in measured gas pressure in the rods over the fill gas pressure (1 atm) fell into two distinct groups: those with negligible pressure increase and those with a definite measurable pressure increase.

Figure 29 shows the fission gas collection system, which consists of an evacuable sleeve that contains a mechanical punch and fits over the plenum region of the rod; a series of calibrated expansion volumes that contain

(a) Another rod from assembly G11 was subsequently punctured to obtain additional fission gas release data. 


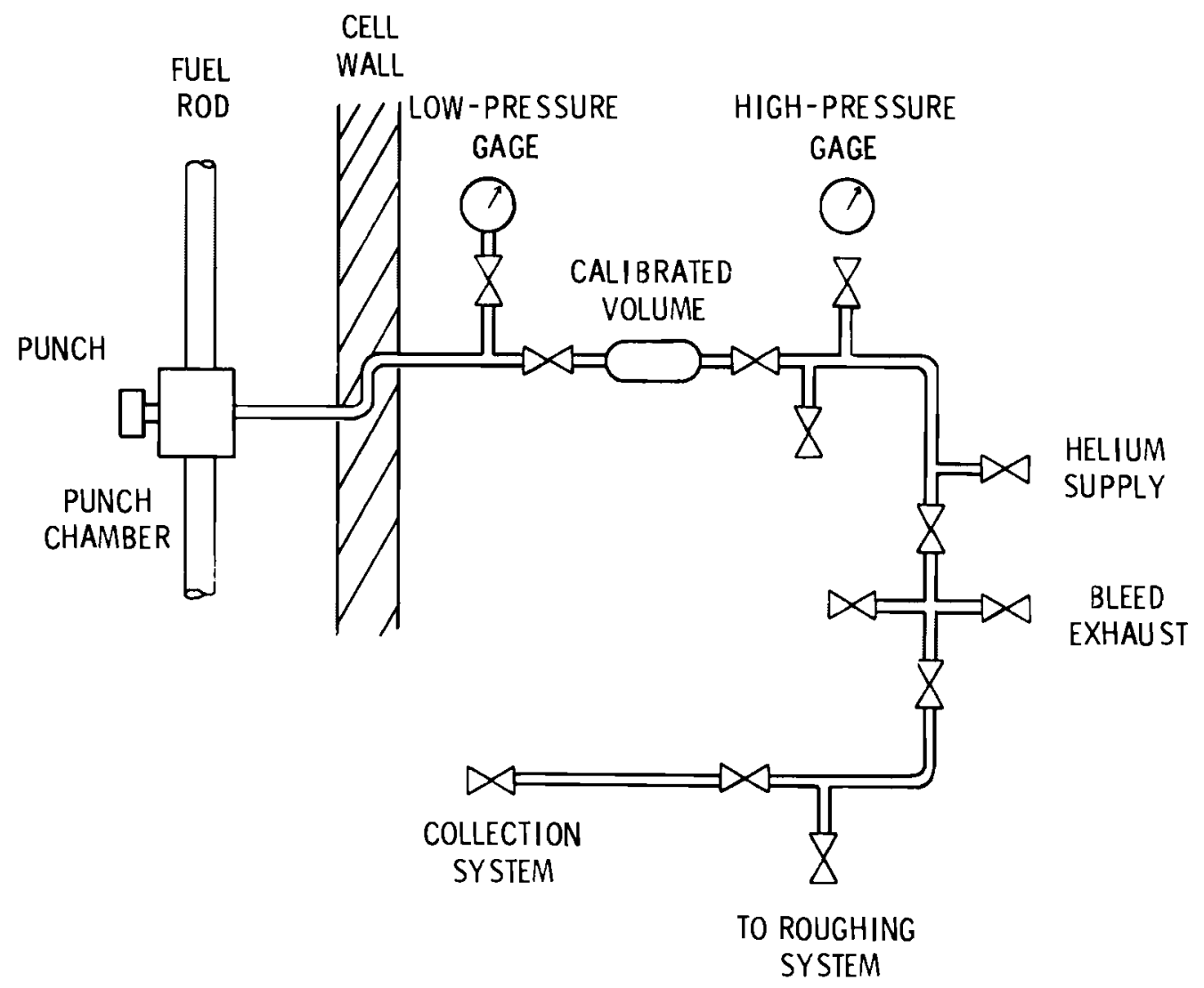

FIGURE 29. Schematic Diagram of the Fission Gas Collection System Used at the Hot-Cell Facility at Battelle Columbus Laboratories

low-range ( 0 to $15 \mathrm{ps} i$ ) and high-range ( 0 to $199 \mathrm{psi}$ ) pressure gages; a collection system with a Toepler pump; and an evacuation system. The collection procedure is to insert the rod and seal the punch chamber. The entire system (punch chamber, expansion system, pressure gauges, and collection system) is evacuated to a few microns pressure. The prepunch system volume $\left(V_{s}\right)$ is measured by pressurizing the punch chamber to about $80 \mathrm{psi}(0.55 \mathrm{MPa})$ with helium and then expanding it into a known volume. The system volume $\left(V_{s}\right)$ is calculated by the pressure drop. This step is repeated 10 times. The system is evacuated to less than $50 \mu \mathrm{m}$ and the pressure and the hot-cell, collection system, and collection vial temperatures are recorded.

When the rod is punctured, pressure readings are recorded on puncturing, at a 2 -min interval and subsequent 5 -min intervals until the system equilibrates. The total system and rod void volumes $\left(V_{t}\right)$ are measured. The rod 
gas is expanded into the collection system and then Toepler-pumped into two vials. These vials are removed from the system. One is sent for mass spectrometric analysis; the other is held as a backup. The total system and rod void volumes $\left(V_{t}\right)$ are then measured by again pressurizing the punch chamber to about 80 psi with helium and expanding it into a known volume. This step is repeated 10 times. From these data, the rod void volume, the prepuncture rod pressure, and the amount of gas contained in the rod are calculated.

The high (AHR) and low (ABG) burnup fuel rods from assembly S004 were the first to be selected and punctured for fission gas collection and analysis. Rods ADT and AGD were selected for supplemental analysis after an order of magnitude difference in prepuncture rod pressures and fission gas release was indicated for $A H R$ and $A B G$. Hydrogen was present in the gases collected from all the S004 rods; negligible hydrogen was measured in fuel rods from assemblies $\mathrm{H} 07$ and G11. The $\mathrm{Xe} / \mathrm{Kr}$ ratios for the four rods showed no burnup dependence in the range of burnups measured. The fission gas releases fell into two ranges and correlated more with fuel temperature during irradiation, as estimated from the appearance of the microstructure, than with rod power or burnup. It should be noted that the fuel rods from assembly S004 were not of the prepressurized type. S004 fuel densified about the same amount as G11 fue 1 but swelled at a lower rate than Gll fuel. Results from a study by Belgonucleaire (Bouffioux and De Meulemeester 1979) and from an EPRI-sponsored program (Fuhrman et a 1. 1976) show that large variations in fission gas release can occur in two fuel rod groups with nominally the same power history because of densification of the fue 1 and thermal feedback effects. The densification and thermal feedback result in a larger gap between the fuel and cladding, higher temperature, and higher gas release.

The prior studies of fission gas release versus fuel temperature (Bouffioux and De Meulemeester 1979; Fuhrman et al. 1976) indicated that gas releases in rods from assembly S004 would not be expected to occur while the rods were in pool storage at low temperatures. The void volumes determined for these rods ranged from $21.35 \mathrm{~cm}^{3}$ to $24.71 \mathrm{~cm}^{3}$ with an average value for the four rods of $22.78 \mathrm{~cm}^{3}$. Table 17 lists the temperature, pressure, and volume measurements. Table 18 gives rod gas composition and fuel burnup information. 
TABLE 17. Measurements for Gases Collected from Connecticut Yankee Fue 1 Rods

\begin{tabular}{|c|c|c|c|c|c|c|c|c|}
\hline $\begin{array}{l}\text { Assembly- } \\
\text { Fue } 1 \text { Rod }\end{array}$ & Report & $\begin{array}{l}\text { Total System } \\
\text { Volume } V_{T} V_{T}\end{array}$ & $\begin{array}{c}\text { Initial System } \\
\text { Volume } \\
V_{S}\end{array}$ & $\begin{array}{l}\text { Rod Void } \\
\text { Volume, } V_{R}\end{array}$ & $\begin{array}{r}\text { Expa } \\
\text { Pressu } \\
\end{array}$ & $\begin{array}{l}\text { ded } \\
\text { in } V_{T}\end{array}$ & Temper & re $\left({ }^{\circ} \mathrm{C}\right)$ \\
\hline Designation & Date & & & & (psi) & $(\mathrm{Pa})^{\prime}$ & System & In-Cel1 \\
\hline SO04-ABG & $8 / 26 / 80$ & 497.24 & 472.53 & 24.71 & 1.07 & 7,380 & 22.0 & 24.0 \\
\hline -ADT & $2 / 25 / 81$ & 495.34 & 473.99 & 21.35 & 1.19 & 8,210 & 21.5 & 25.5 \\
\hline -AHR & $8 / 25 / 80$ & 495.56 & 473.01 & 22.55 & 6.91 & 47,600 & 22.0 & 23.5 \\
\hline$-A G D$ & $2 / 25 / 81$ & 496.05 & 473.54 & 22.51 & 10.57 & 72,600 & 23.0 & 25.0 \\
\hline H07-157ED1 & $6 / 19 / 80$ & 493.32 & 474.66 & 18.66 & 1.19 & 8,210 & 23.0 & 24.8 \\
\hline$-062 \mathrm{E} 12$ & $6 / 18 / 80$ & 493.02 & 472.16 & 20.86 & 1.25 & 8,620 & 22.0 & 25.0 \\
\hline$-217 \mathrm{E} 02$ & $6 / 20 / 80$ & 492.64 & 472.34 & 20.30 & 1.46 & 10,100 & 22.5 & 25.5 \\
\hline G11-595A10 & $10 / 8 / 80$ & 494.50 & 473.57 & 20.93 & 4.60 & 31,700 & 22.0 & 24.0 \\
\hline
\end{tabular}


TABLE 18. Compositions of Collected Gases and Calculated Fuel Burnups for Selected Connecticut Yankee Fue 1 Rods

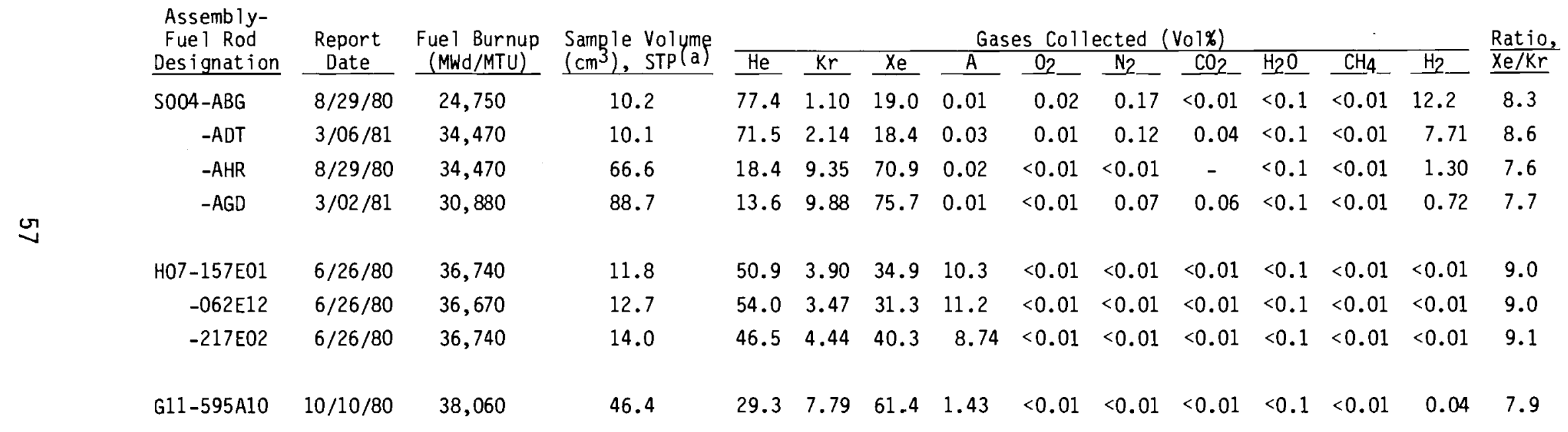

(a) STP = standard temperature and pressure. 
Table 19 lists the prepuncture rod pressures computed for Connecticut Yankee fuel rods. The gas pressures were computed using ratios derived from the Ideal Gas Law, assuming that the number of moles of gas was constant. Isothermal $\left(23^{\circ} \mathrm{C}\right)$ conditions were assumed because the system and in-cell temperatures on ly varied from $21^{\circ} \mathrm{C}$ to $26^{\circ} \mathrm{C}$. The helium and argon pressures are included to point out that additional helium was generated and released during irradiation if the original rod filling pressure was $1 \mathrm{~atm}$. The helium and argon pressures were calculated by multiplying the gas pressure $\left(P_{r}\right)$ by the volume fractions of helium and argon in the collected gases (see Table 18).

The percent of fission gas released during irradiation was calculated by determining the total moles of $\mathrm{Xe}$ and $\mathrm{Kr}$ in the collected gas and dividing that number by the total moles of $\mathrm{Xe}$ and $\mathrm{Kr}$ generated based on a calculation that considered the fuel stack weight and the fuel burnup (see Table 20). The calculated value for burnup agreed we 11 with the measured burnup value for rods AHR and AJQ. The largest difference between calculated burnup and a value est imated from the ${ }^{137}$ Cs correlation (see Figure 23) for burnup was for rod $A B G$; the calculated value was about $17 \%$ below the ${ }^{137}$ Cs correlation value. The calculated values for burnup were used in the calculation of fission gas re lease.

The moles of $\mathrm{Xe}$ and $\mathrm{Kr}$ in the collected gases were determined by Amagat's Law of partial volumes:

$$
n=\frac{P_{S} V_{s}}{R T}(X e+K r)
$$

where $\quad n=$ number of moles of $\mathrm{Xe}+\mathrm{Kr}$

$P_{s}=$ system pressure after rod puncture, i.e., expand (volume atm)

$v_{S}=$ total system volume after rod puncture $(l)$

$\mathrm{T}=$ collection system temperature $(K)$

$R=0.08206 \ell$-atm/K-mo le

$\mathrm{Xe}, \mathrm{Kr}=\mathrm{Xe}$ and $\mathrm{Kr}$ composition of collected gas (vol. fraction).

The moles of $\mathrm{H}_{2}$ in the collected gases were computed similarly. Table 21 lists the results for the moles of fission gas, i.e., $\mathrm{Xe}$ and $\mathrm{Kr}$, generated during 
TABLE 19. Gas Pressures in Connecticut Yankee Fue 1 Rods

\begin{tabular}{|c|c|c|c|c|c|c|c|c|}
\hline $\begin{array}{l}\text { Assembly- } \\
\text { Fuel Rod } \\
\text { Designation }\end{array}$ & $\begin{array}{c}\text { Total System } \\
\text { Volume } V_{T} \\
\left(\mathrm{~cm}^{3}\right) \\
\end{array}$ & $\begin{array}{l}\text { Rod Void } \\
\text { Volume, } \\
\left(\mathrm{cm}^{3}\right)\end{array}$ & $\begin{array}{l}\text { Expande } \\
\text { Press } \\
\text { (psi) } \\
\end{array}$ & $\begin{array}{l}\text { Sys tem } \\
\text { re, P P } \\
\text { (atm) }\end{array}$ & $\frac{\text { Total Pre }}{P_{R}(p s i)}$ & $\frac{\text { ure in Rod }}{P_{R}(\mathrm{~atm})}$ & $\begin{array}{c}\text { Helium } \\
P_{\mathrm{He}} \text { (atm) }\end{array}$ & $\begin{array}{c}\text { Argon } \\
\operatorname{Par}_{A}(\mathrm{~atm})\end{array}$ \\
\hline $5004-A B G$ & 499.24 & 24.71 & 1.07 & 0.072 & 21.53 & 1.46 & 1.03 & -- \\
\hline -ADT & 495.34 & 21.35 & 1.19 & 0.081 & 27.61 & 1.88 & 1.34 & -- \\
\hline -AHR & 495.56 & 22.55 & 6.91 & 0.470 & 151.85 & 10.33 & 1.90 & -- \\
\hline$-A G D$ & 496.05 & 22.51 & 10.57 & 0.719 & 232.93 & 15.85 & 2.16 & -- \\
\hline 107-157E01 & 493.32 & 18.66 & 1.19 & 0.081 & 31.46 & 2.14 & 1.09 & 0.22 \\
\hline$-062 E 12$ & 493.02 & 20.86 & 1.25 & 0.085 & 29.54 & 2.01 & 1.09 & 0.225 \\
\hline$-217 E 02$ & 492.64 & 20.30 & 1.46 & 0.099 & 35.43 & 2.41 & 1.12 & 0.21 \\
\hline $11-595 A 10$ & 494.50 & 20.93 & 4.60 & 0.313 & 108.68 & 7.39 & 2.17 & 0.11 \\
\hline
\end{tabular}


TABLE 20. Fission Gas Release in Selected Connecticut Yankee Fuel Rods

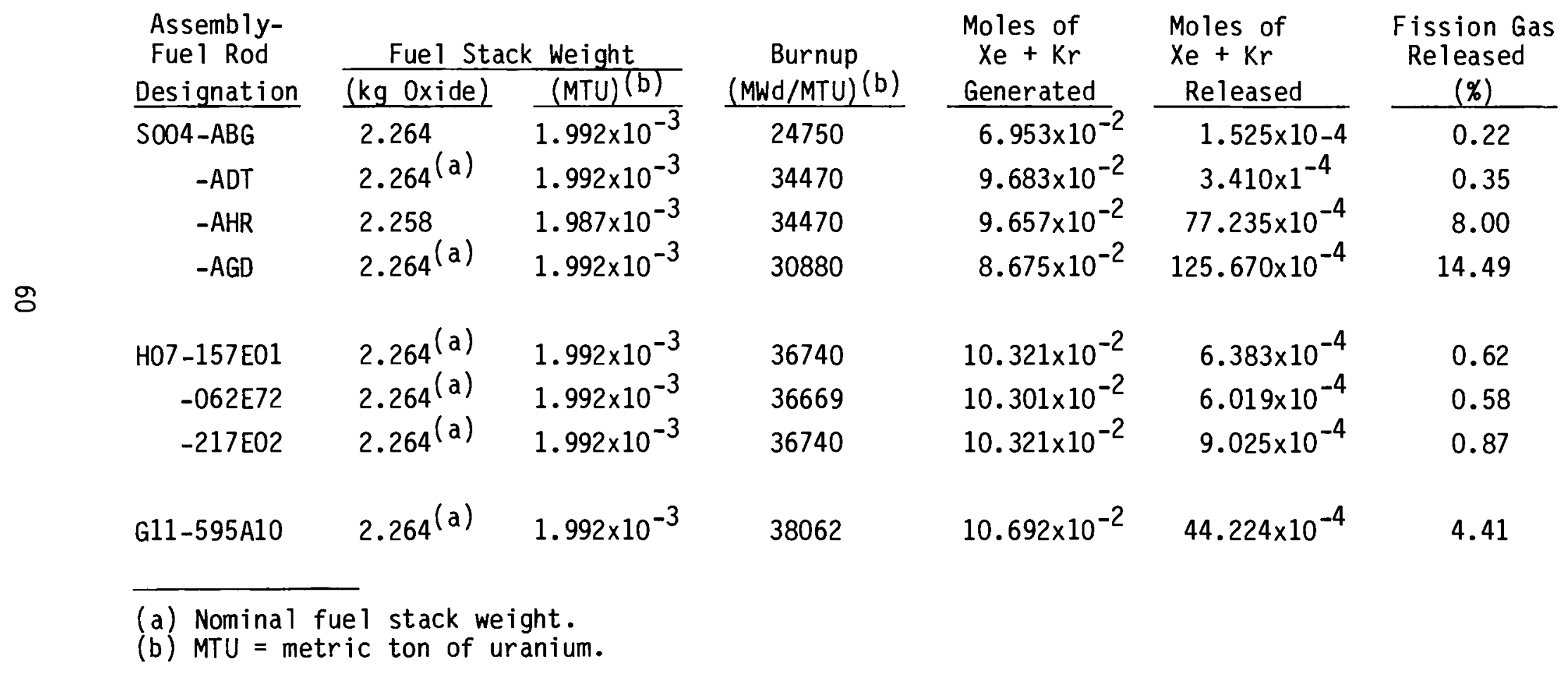


TABLE 21. Moles of $(\mathrm{Xe}+\mathrm{Kr})$ and $\mathrm{H}_{2}$ in Selected Connecticut Yankee Fuel Rods

\begin{tabular}{|c|c|c|c|c|c|c|c|c|c|}
\hline $\begin{array}{l}\text { Assembly- } \\
\text { Fuel Rod } \\
\text { Designation }\end{array}$ & $\underline{P}_{s}(\mathrm{~atm})$ & $v_{s}(1)$ & $I(K)$ & $\begin{array}{c}\mathrm{Xe}+\mathrm{Kr} \\
\text { (Vol. Fraction) }\end{array}$ & $\begin{array}{c}\text { Moles of } \\
\mathrm{Xe}+\mathrm{Kr} \\
\text { Collected } \\
\end{array}$ & $\begin{array}{l}\mathrm{H}_{2} \\
\text { (Vol. Fraction) }\end{array}$ & $\begin{array}{c}\mathrm{H}_{2} \\
\text { (moles) }\end{array}$ & $\begin{array}{c}\mathrm{H}_{2} \\
\text { (grams) } \\
\end{array}$ & $\begin{array}{r}\mathrm{H}_{2} \mathrm{O} \\
(\mathrm{ppm}) \\
\end{array}$ \\
\hline SO04-ABG & 0.0728 & 0.4972 & 295.0 & 0.1020 & $1.525 \times 10^{-4}$ & 0.122 & $1.82 \times 10^{-4}$ & $3.28 \times 10^{-4}$ & 1.5 \\
\hline -ADT & 0.0810 & 0.4953 & 294.5 & 0.2054 & $3.410 x$ & 0.077 & $1.28 \times 10^{-4}$ & $2.30 \times 10^{-4}$ & 1.0 \\
\hline$-A H R$ & 0.4701 & 0.4956 & 295.0 & 0.8025 & $77.235 x$ & 0.013 & $1.25 \times 10^{-4}$ & $2.25 \times 10^{-4}$ & 1.0 \\
\hline$-A G D$ & 0.7190 & 0.4961 & 296.0 & 0.8558 & $125.670 x$ & 0.0072 & $1.06 \times 10^{-4}$ & $1.90 \times 10^{-4}$ & 0.8 \\
\hline$-217 E 02$ & 0.0993 & 0.4926 & 295.5 & 0.4474 & $9.025 x$ & $<0.0001$ & -- & -- & -- \\
\hline G11-595A10 & 0.3129 & 0.4945 & 295.0 & 0.6919 & $44.224 x$ & $<0.0001$ & $0.06 \times 10-4$ & 0.12 & 0.05 \\
\hline
\end{tabular}


irradiation and the moles of $\mathrm{H}_{2}$ in the collected gases and the bulk concentration (ppm) of $\mathrm{H}_{2} \mathrm{O}$ in the fuel necessary to yield the amount of $\mathrm{H}_{2}$ measured.

The moles of fission gas ( $\mathrm{Xe}$ and $\mathrm{Kr}$ ) generated by fuel fissions during irradiation are calculated by the following expression:

$$
N_{0}=\left(1.41 \times 10^{-3}\right)(B U)(W)
$$

where $N_{0}=$ number of moles of $\left(X_{e}+K r\right)$

$B U$ = fuel burnup (MWd/MTU)

$W=$ fuel stack weight (MTU)

\section{Rod Marking and Sectioning}

The objective here was to obta in fuel and cladding samples to characterize the fuel through fuel density measurements, burnup analysis, autoradiography, ceramography, fuel cladding tests, metallography, and mechanical testing while disturbing the fuel and cladding as little as possible.

The axial sample locations, as measured from the bottom end of the fuel rod (see Figures 3 and 13), were established by reference to nondestructive examinations and from calculated values of rod power and fuel burnup (see Figures $7,8,9)$. The locations were indexed on the outer surface of the cladding with a tube cutter, which made circumferential scribe marks with an axial accuracy of $\pm 1 / 32 \mathrm{in}$. $(0.79 \mathrm{~mm})$. Motor-driven chucks gripped each end of the fuel rod and rotated it during marking. After marking was completed, the rod was removed from the marking tool and placed in the sectioning tool.

A rotating chuck and tubing cutter comprised the sectioning tool. This tool provided cladding sections with crimped ends that were sufficiently deformed to retain individual pellets or large fragments of cracked pellets. The first cuts were made at $42.25 \mathrm{in} .(107 \mathrm{~cm})$ and $80.50 \mathrm{in} .(204 \mathrm{~cm})$ above the bottom of the rod. The lower two sections were marked at the section top, in line with the $0^{\circ}$ reference mark cut in the upper end cap (assembly west direction, as shown in Figures 2 and 12), with a burring tool to identify the azimuthal orientation (for an example see Figure 38 in the Metallography 
subsection) and the section top end. The sections were inserted into containers marked with the section identification. The specimens were transferred to the high-level cell for further sectioning.

Further sectioning was accomplished with an abrasive cut-off saw. A flow of water was used to cool the cut area and control contamination. A white paint dot was placed near the top end of each cut piece, in line with the cut mark on the top end of the rod. The cut sections were placed in individual containers marked with the section identification. Each container was listed and stored for retrieval for the desired examinations. Care was taken to prevent loss of fuel fragments. However, the water coolant disturbed the soluble fission products in the samples intended for fuel leach testing. Therefore, fuel leach testing was not included in the examinations. The sample numbers are listed in Tables 22 and 23 along with sample location and the examination requested.

\section{Fuel Burnup Analys is}

The burnup sample (No. 8) was taken immediately below the mid-core plane of fuel rod AHR, a high burnup rod from assembly S004. The burnup analys is yielded a value of 4.209 at.\% or $40,410 \mathrm{MNd} / \mathrm{MTU}$. This value compares we 11 with the peak burnup of 41,400 MWd/MTU calculated for AHR by multiplying the rod average burnup $(34,473$ MWd/MTU) times the peaking factor. A value of 1.2 was used for the peaking factor. (a)

The sample was dissolved in the chemistry hot cell by refluxing in $12 \underline{N}$ nitric acid. All glassware was new and each piece was cleaned in boiling $8 \underline{\mathrm{N}}$ $\mathrm{HNO}_{3}$ prior to use, as required by American Society for Testing and Materials (ASTM) procedure E-267. The dissolved uranium samples were diluted to a concentration of $0.001 \mathrm{gU} / \mathrm{ml}$ with $8 \mathrm{~N} \mathrm{HNO}_{3}$. The $\mathrm{BCL}$ mass spectrometer laboratory conducted the burnup analysis by the ${ }^{148} \mathrm{Nd}$ method (ASTM E-321). Results of the mass spectrometric analys is are shown in Table 24. The burnup and timeaverage linear heat generation rates were calculated for each rod by normalizing the gamma scanning data for each rod to the analytically determined burnup values.

(a) For assemblies $\mathrm{H} 07$ and G11, a value of 1.15 was used for the peaking factor (see page 3-45 in Pasupathi and Klingensmith 1981). 
TABLE 22. Sectioning for Fue 1 Rod AHR from Assembly S004

$\frac{\text { Sample No. }}{1 \& 1 \mathrm{~A}} \frac{\text { Location }^{(\mathrm{b})} \text { (in.) }}{0.00-1.00}$

\begin{tabular}{|c|c|c|}
\hline 3 & $1.00-1.50$ & Density \\
\hline $3 A$ & $1.50-2.00$ & Density \\
\hline $3 B$ & $2.00-24.00$ & Remnant \\
\hline $3 C$ & $24.00-29.00$ & Tensile \\
\hline 30 & $29.00-34.00$ & Tensile \\
\hline $3 E$ & $34.00-34.50$ & Ring Tensile \\
\hline $3 F$ & $34.50-35.00$ & Ring Crush \\
\hline $3 G$ & $35.00-35.50$ & Ring Tensile \\
\hline $3 \mathrm{H}$ & $35.50-36.00$ & Ring Crush \\
\hline 4 & $36.00-36.50$ & Transverse Met. (Top Face) \\
\hline 5 & $36.50-37.50$ & Leach (Wet Cut) \\
\hline 6 & $37.50-42.25$ & Remnant \\
\hline 7 & $42.25-43.75$ & Remnant \\
\hline $7 \mathrm{~A}$ & $43.75-48.75$ & Tensile \\
\hline $7 \mathrm{~B}$ & $48.75-49.25$ & Ring Tensile \\
\hline $7 C$ & $49.25-49.75$ & Ring (Save) \\
\hline 70 & $49.75-50.25$ & Ring Crush \\
\hline $7 E$ & $50.25-50.75$ & Ring (Save) \\
\hline $7 F$ & $50.75-55.75$ & Tensile \\
\hline 8 & $55.75-56.25$ & Burnup \\
\hline 9 & $56.25-56.75$ & Transverse Met. (Top Face) \\
\hline 10 & $56.75-57.75$ & Leach (Wet Cut) \\
\hline 11 & $57.75-58.25$ & Density \\
\hline 12 & $58.25-58.75$ & Density \\
\hline $12 \mathrm{~A}$ & $58.75-59.25$ & Ring Tensile \\
\hline
\end{tabular}

Examination at Lower End Cap

Density

Longitudinal Metallographic (Met.) Sample 


\section{TABLE 22. (Contd)}

\begin{tabular}{|c|c|c|}
\hline Sample No. & Location (in.) & Examination \\
\hline $12 \mathrm{~B}$ & $59.25-59.75$ & Ring Crush \\
\hline $12 \mathrm{C}$ & $59.75-60.25$ & Ring (Save) \\
\hline $12 D$ & $60.25-65.25$ & Tensile \\
\hline $12 \mathrm{E}$ & $65.25-65.75$ & Ring \\
\hline $12 \mathrm{~F}$ & $65.75-66.25$ & Ring \\
\hline $12 G$ & $66.25-71.25$ & Tensile \\
\hline $12 \mathrm{H}$ & $71.25-71.75$ & Ring \\
\hline \multicolumn{3}{|l|}{ (a) } \\
\hline $12 \mathrm{~J}$ & $71.75-72.25$ & Ring \\
\hline $12 \mathrm{~K}$ & $72.25-72.75$ & Ring \\
\hline $12 \mathrm{~L}$ & $72.75-73.25$ & Ring \\
\hline $12 M$ & $73.25-80.00$ & Remnant \\
\hline 13 & $80.00-80.50$ & Transverse Met. (Top Face) \\
\hline 14 & $80.50-83.25$ & Remnant \\
\hline 15 & $83.25-83.75$ & Transverse Met. (Top Face) Grid Spacer \\
\hline 16 & $83.75-84.50$ & Remnant \\
\hline 17 & $84.50-89.50$ & Tensile \\
\hline $17 \mathrm{~A}$ & $89.50-90.00$ & Ring Tensile \\
\hline $17 \mathrm{~B}$ & $90.00-90.50$ & Ring Crush \\
\hline $17 C$ & $90.50-91.00$ & Ring Crush \\
\hline 170 & $91.00-91.50$ & Ring Tensile \\
\hline $17 \mathrm{E}$ & $91.50-96.50$ & Tensile \\
\hline $17 \mathrm{~F}$ & $96.50-98.25$ & Remnant \\
\hline 18 & $98.25-98.75$ & $\begin{array}{l}\text { Transverse Met. (Bottom Face Eddy Current } \\
\text { Indication) }\end{array}$ \\
\hline 19 & $98.75-125.75$ & Remnant \\
\hline $20 \& 21$ & $125.75-126.66$ & Longitudinal Met. Upper End Cap \\
\hline
\end{tabular}

(a) No Sample $12 i$. 
TABLE 23. Sectioning for Fuel Rod ABG from Assembly S004

\begin{tabular}{lrll} 
Sample No. & Location ${ }^{(a)}$ (in.) & & \multicolumn{1}{c}{ Examination } \\
\hline $1 \& 1 A$ & $0.00-1.00$ & & $\begin{array}{l}\text { Longitudinal Metallographic (Met.) } \\
\text { Samples at Lower End Cap }\end{array}$ \\
2 & $1.00-41.00$ & & Remnant \\
3 & $41.00-41.50$ & Transverse Met. (Top Face Grid Spacer) \\
4 & $41.50-42.25$ & Remnant \\
5 & $42.25-56.25$ & Remnant \\
6 & $56.25-56.75$ & Transverse Met. (Top Face) \\
7 & $56.75-84.50$ & Remnant \\
8 & $84.50-125.75$ & Remnant \\
$9 \& 9 \mathrm{~A}$ & $125.75-126.75$ & Longitudinal Met. Upper End Cap
\end{tabular}

(a) Distance from bottom end of fuel rod.

\section{Fuel Density}

Fuel densities were determined for irradiated samples from rod AHR in the hot cell by using a mercury pycnometer technique. Pairs of samples were evaluated: two from near the lower end cap in a low burnup region and two from just below the core mid-plane, near the burnup sample in a high burnup, high power

TABLE 24. Mass Spectrometric Analys is of Fuel Burnup Sample AHR-8(a)

\begin{tabular}{|c|c|c|c|}
\hline I sotope & Atom Percent & Isotope & Atom Percent \\
\hline $234_{U}$ & 0.026 & $240 \mathrm{Pu}$ & 23.100 \\
\hline $235 u$ & 1.101 & $241_{\mathrm{Pu}}$ & 11.201 \\
\hline${ }^{236} u$ & 0.588 & ${ }^{242} \mathrm{Pu}$ & 5.457 \\
\hline $238 \mathrm{U}$ & 98.285 & ${ }^{148} \mathrm{Nd} /{ }^{238}$ & $7.594 \times 10^{-4}$ \\
\hline${ }^{238} \mathrm{Pu}$ & 2.501 & ${ }^{239} \mathrm{Pu} /{ }^{238}$ & $6.516 \times 10^{3}$ \\
\hline${ }^{239} \mathrm{Pu}$ & 57.740 & & \\
\hline
\end{tabular}

(a) The burnup of the sample was 40,410 Md/MTU (4.209 at.\%). 
region. The results indicated that the fuel underwent a densification of almost $2 \%$, but the net density change in the high power, high burnup region was almost nil.

The results of the fuel density measurements are given in Table 25. The original mean as-sintered fuel density was $10.215 \mathrm{~g} / \mathrm{cm}^{3}$ or $93.20 \%$ of theoretical density.

\section{Metal lography}

Metallographic specimens were examined for evidence of surface crud and/or oxide layers, corrosive attack, and cracking. Other goals were to document the microstructure of the cladding, end caps, and weld areas, as well as the geometry of the cladding ovality and fuel-cladding gap. The specimens were cut with an abrasive cut-off wheel. Again, water was used for cooling the sample and controlling dust. The cut specimen was placed in a stainless steel sleeve to reduce edge rounding during polishing. The specimen was oriented so that the prepared metallographic surface would either be transverse or parallel with the rod axis. The sample and sleeve were then positioned in a bakelite holder with markers to denote the rod $0^{\circ}$ azimuthal orientation. The entire assembly was placed in a bell jar; the jar was evacuated and a cold-setting epoxy resin was

TABLE 25. Measured Fuel Densities for Rod AHR from Assembly S004

\begin{tabular}{|c|c|c|c|}
\hline \multirow[b]{2}{*}{ Sample No. } & \multirow{2}{*}{$\begin{array}{l}\text { Axial Location(a) } \\
\text { (in. above bottom } \\
\text { of fuel rod) }\end{array}$} & \multicolumn{2}{|c|}{ Fue 1 Density } \\
\hline & & $\left(\mathrm{g} / \mathrm{cm}^{3}\right)$ & $q \mathrm{TD}(\mathrm{b})$ \\
\hline 3 & $1.00-1.50$ & 10.435 & 95.21 \\
\hline $3 A$ & $1.50-2.00$ & 10.438 & 95.24 \\
\hline 11 & $57.75-58.25$ & 10.233 & 93.37 \\
\hline 12 & $58.25-58.75$ & 10.255 & 93.57 \\
\hline
\end{tabular}

(a) The average burnup for rod AHR was 34,473 MWd/MTU and maximum burnup (see section on fuel burnup analysis) was 40,410 MWd/MTU.

(b) Theoretical density (TD) of $\mathrm{UO}_{2}$ is $10.96 \mathrm{~g} / \mathrm{cm}^{3}$. The as-fabricated mean pellet density was $10.215 \mathrm{~g} / \mathrm{cm}^{3}$ (93.20\% TD). 
poured over the sample to fill the cavity. This process was repeated until satisfactory impregnation of the mount was obtained. The resin required a $12-\mathrm{hr}$ curing time.

The metallographic specimens were ground with silicon carbide abrasive papers (120 through 600 grit) and polished with a slurry of Linde $A$ alumina in a $2 \%$ chromic acid solution. The specimens were examined in both as-polished and etched conditions. Two etchants were used: a) 50 parts HC1/10 parts $\mathrm{HNO}_{3}$ and b) $10 \%$ oxalic acid with electrolytic etching.

The metallurgical structure of the base material was essentially equiaxed with twinning and slip band formations present. Figure 30 shows archive material; Figure 31 shows irradiated material for comparison. Figure 32 illustrates that the grain size did not change significantly through the wall of the cladding. The grain size in the seam weld heat-affected zone (HAZ) was very similar in the rods from the three fuel assemblies (S004, G11, H07). The inclusion population was divided into two categories, similar to results reported by Babcock and Wilcox $(1979)^{(a)}$ for cladding used in the G11 and H07 assemblies. The inclusions were either of the elongated or fragmented stringer type or of the small, isolated type.

The etched samples showed microstructures typical of stainless steel cladding, welds, and end caps. The archive and irradiated materials in Figures 30 and 31 show that the thermo-mechanical history of the tube seam weld has resulted in a uniform, wrought microstructure with a finer grain size than the unwelded metal in the cladding. Figures 33 and 34 show selected microstructures typical of the irradiated stainless steel cladding, weld, end cap, and HAZ material examined. The irradiated material appears to have fewer carbides and twins than the archive material. This may be due to specimen preparation. Again, even in the high magnification photographs of the weld areas, no oxide or crud layers, corrosion attack, or cracking are evident.

The end cap welds showed a dendritic structure characteristic of rapidly quenched austenitic weld metal. Surface flaws on the cladding ID were

(a) "Examination of Connecticut Yankee Archive Cladding ID Surface." Letter Report LR:79:6861-01:1, Babcock and Wilcox Company, Lynchburg Research Center, Lynchburg, Virginia, May 30, 1979. 
reported (Babcock and Wilcox 1979) for archive fuel cladding. Pre-existing flaws of this type are probably present in the S004 cladding and explain some of the observed surface roughness that cannot be attributed to fuel handling or machining operations.

Two etchants were used for the cladding. Micrographs with negative numbers up to $\mathrm{HC} 50381$ represent surfaces etched with $50 \mathrm{HCl}-10 \mathrm{HNO}_{3}$. Micrographs with negative numbers of HC50381 or greater show surfaces electrolytically etched with $10 \%$ oxalic acid. The etchant was changed because of excessive pitting encountered with the $50 \mathrm{HCl}-10 \mathrm{HNO}_{3}$ etchant. Figure 35 shows examples of surfaces prepared with each etchant. The variation in oxalic acid etching characteristics is illustrated in Figures 36 and 37 . Over-etching occurred in the cladding away from the weld area.

Generally, oxides and crud were not discernible on OD cladding surfaces at magnification up to 500x. Oxides also were not detected on the ID surfaces (see Figures 38 through 41), in contrast to Zircaloy-clad fuel. However, observation of very thin surface layers, such as the crud or oxide layers that could be present on this cladding, is strongly dependent on the sample preparation and the optical resolution limits of the metallograph. Sample preparation with specimen edge retention of the caliber required to show th in surface films is very difficult, especially when the work is being performed in a hot cell. Some OD areas showed gouging (Figure 42) typical of handling marks and the axial scratches inflicted by grid-spacer springs when the rods are inserted into or withdrawn from the fuel assembly (Figure 16). Corrosive attack or cracking was not evident in the cladding. Examination of cladding seam and end cap welds and weld heat-affected zones showed no evidence of intergranular corrosion or stress-corrosion cracking.

The cladding surface condition was generally very smooth with no measurable surface layers in the fuel rods examined from the three assemblies (Figures 43 through 47). However, the light brown cladding surface appearance suggested the presence of a thin surface oxide. There were no apparent differences in corrosion between the cladding or base material, the weld area, and the weld heat-affected zone. 

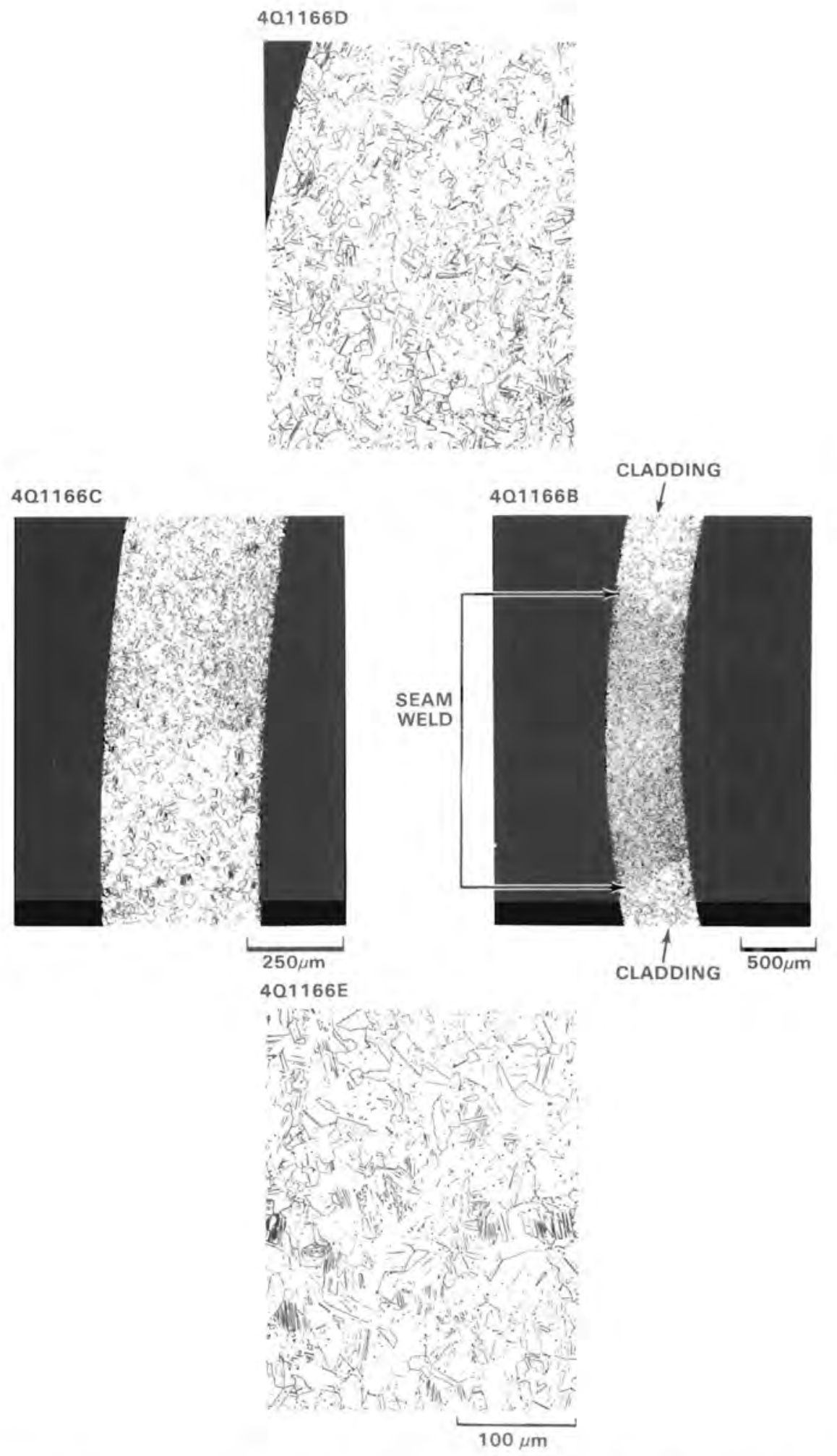

FIGURE 30. Meta1lography of Archive 304L Stainless Steel Cladding for Fuel Rods in the 5004 Assembly (Oxalic Acid Etchant). See Table 2 for fabrication method. 


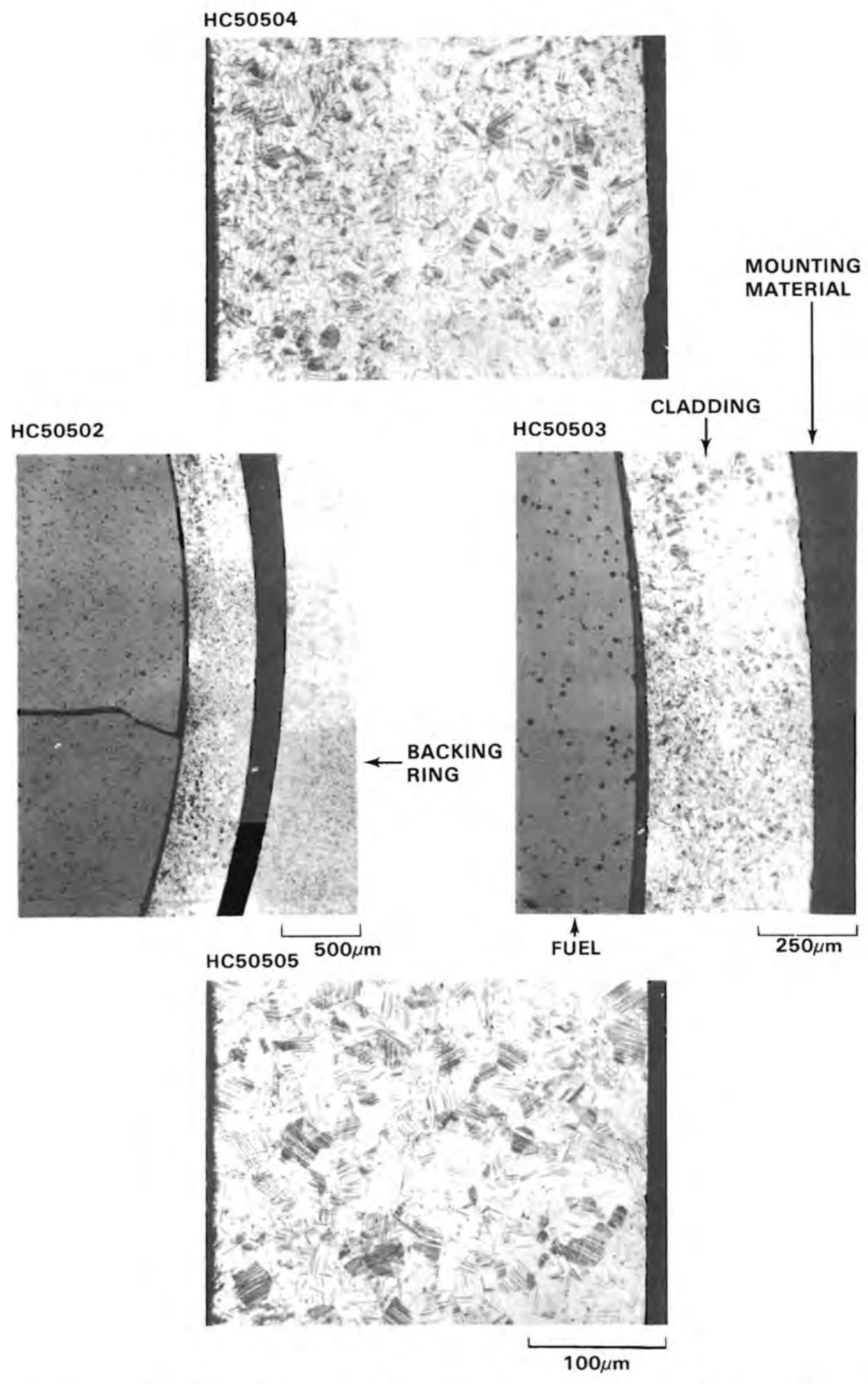

FIGURE 31. Metallography of Cladding from S004 Fuel Rod ABG, 56.75 in. $(144 \mathrm{~cm})$ Above Rod Bottom (Oxalic Acid Etchant) 


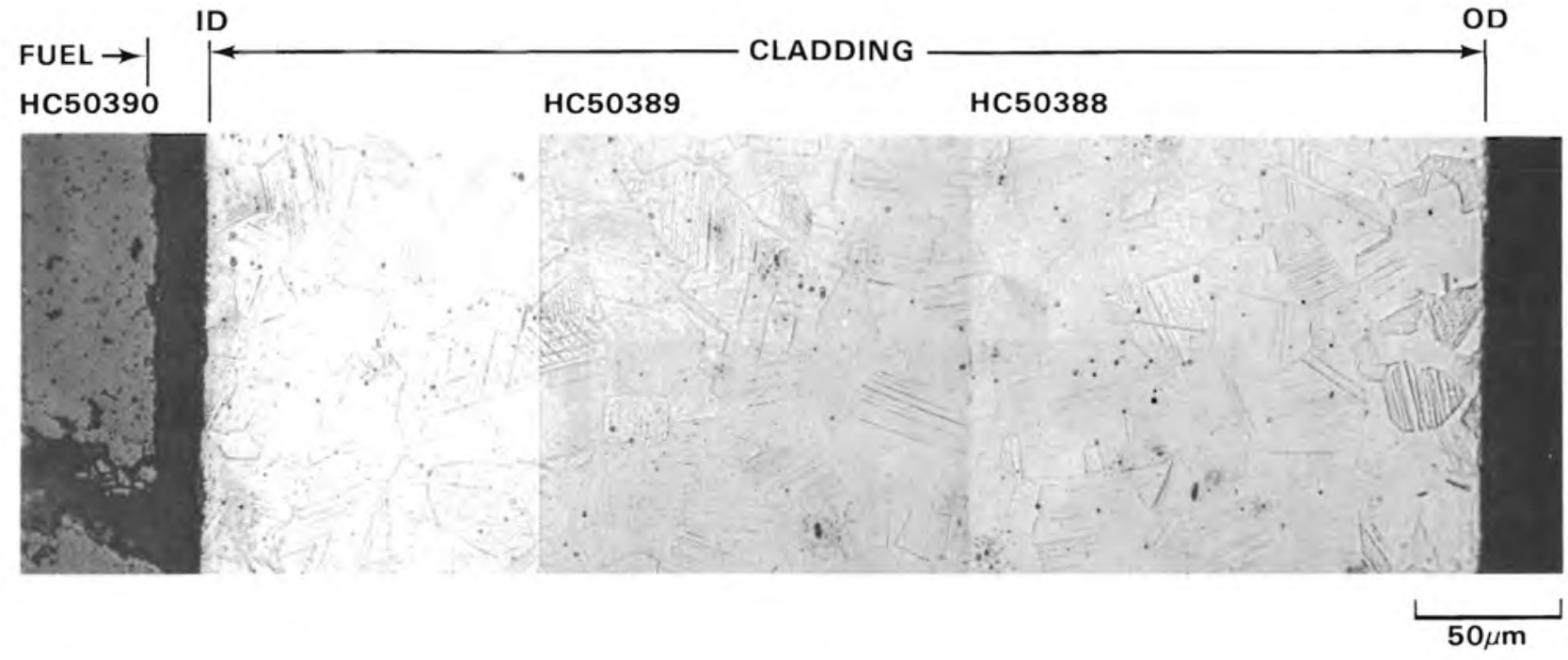

HC50819

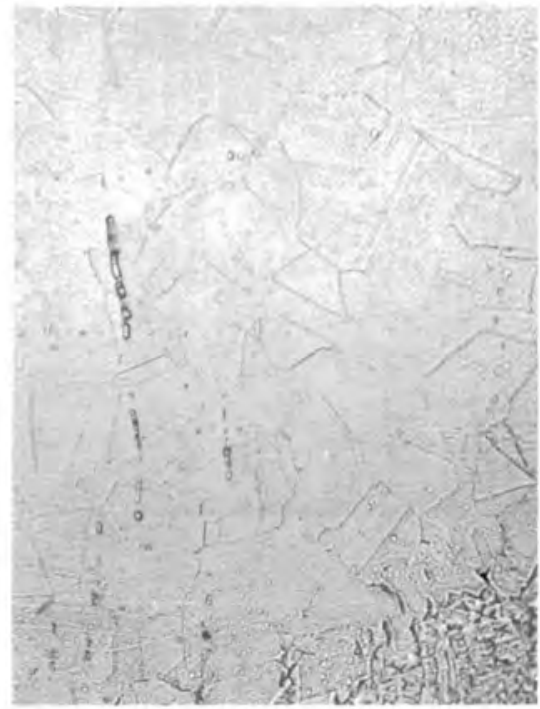

HC50808

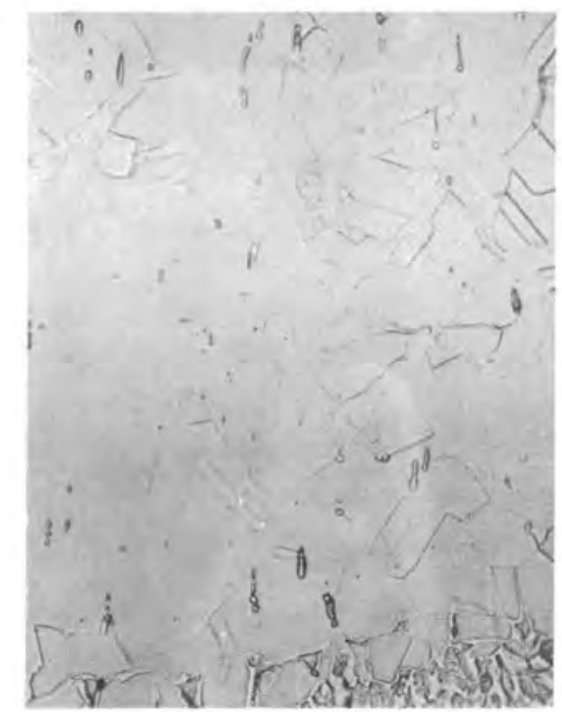

HC50813

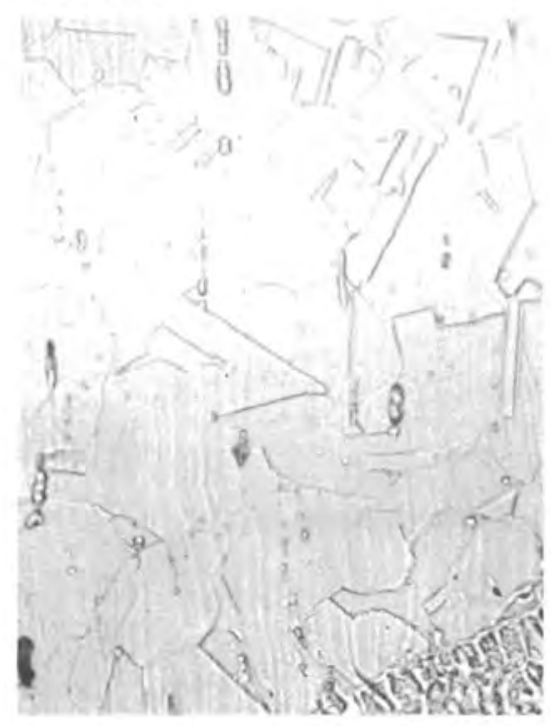

$50 \mu \mathrm{m}$

FIGURE 32. Metallography of Cladding from Connecticut Yankee Fuel Rods 


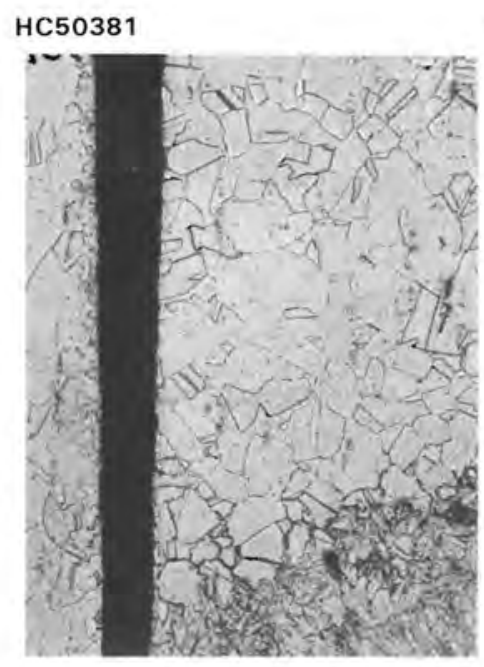

HC50384

HC50137

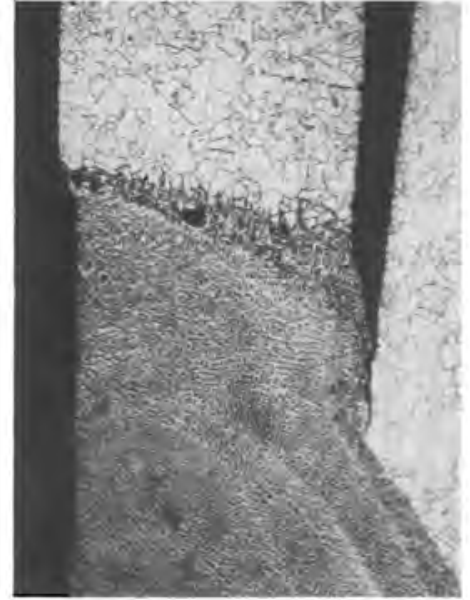

ROD AHR

50 HCR-10 HNO
HC50380

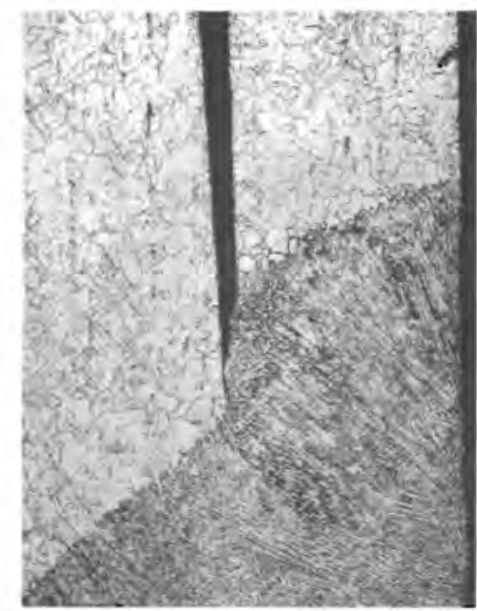

ROD ABG

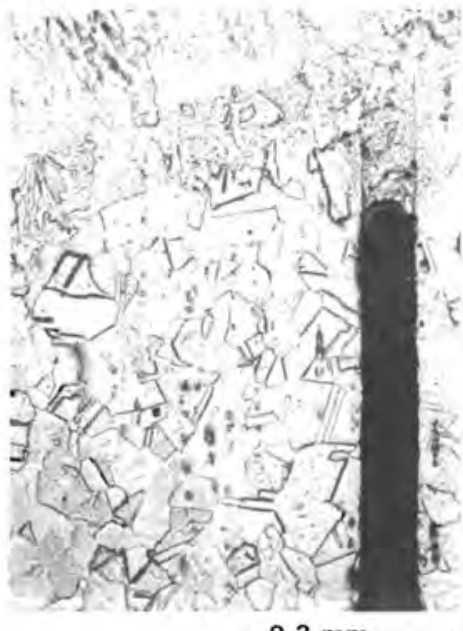

HC50383

$10 \%$ OXALIC ACID-ELECTROLYTIC

FUEL ROD END CAP WELD AREAS

FIGURE 33. Metallography Showing the Heat-Affected Zone of End Cap Weld Areas from Connecticut Yankee Fuel Rods (Longitudinal Section; Etched Condition) 


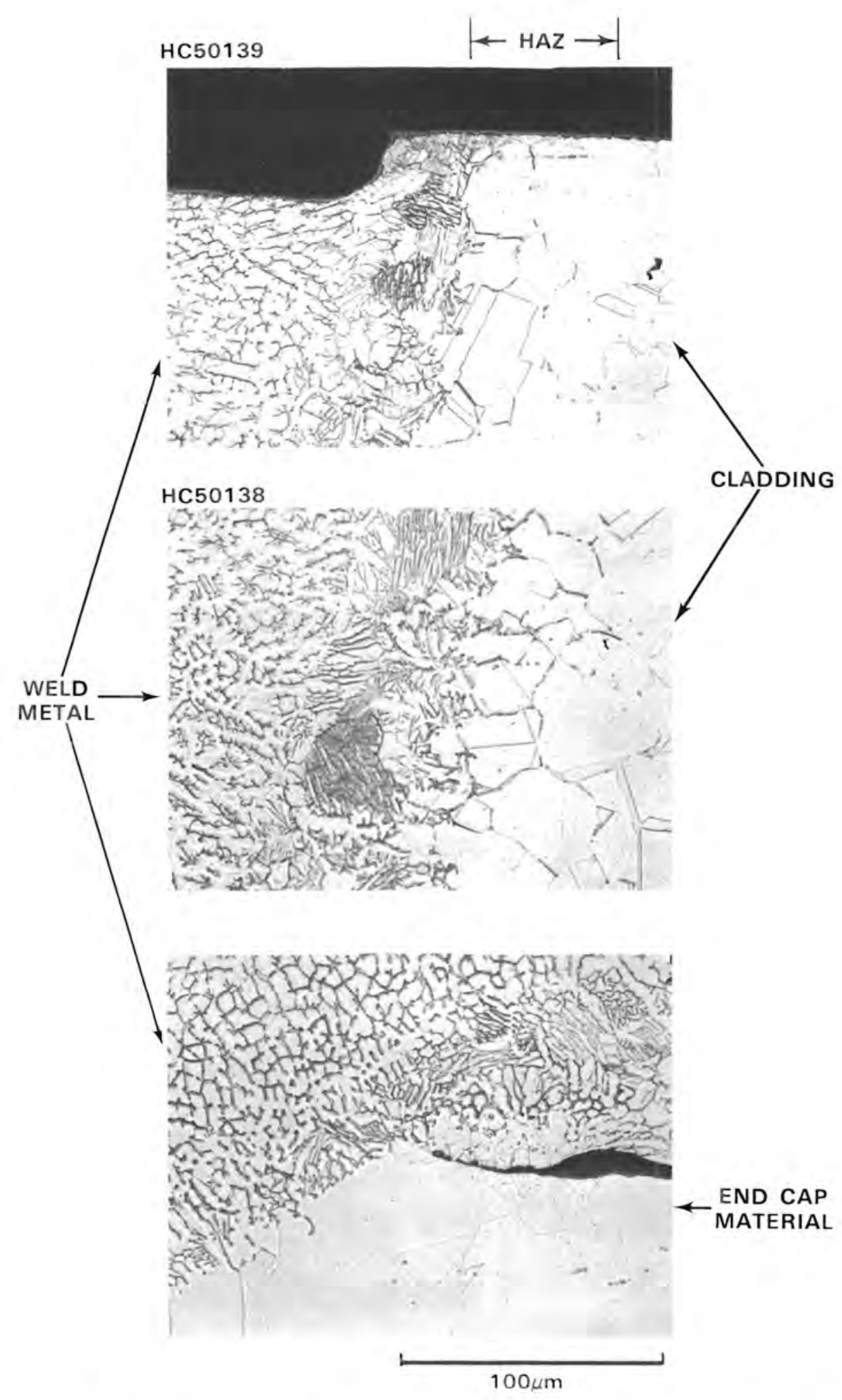

FIGURE 34. Metallography of Weld Heat-Affected Zone (HAZ) from the Lower End Cap, Fuel Rod AHR, Assembly S004 (Longitudinal Section; Etchant $50 \mathrm{HCl}-10 \mathrm{HNO}_{3}$ ) 
HC49910

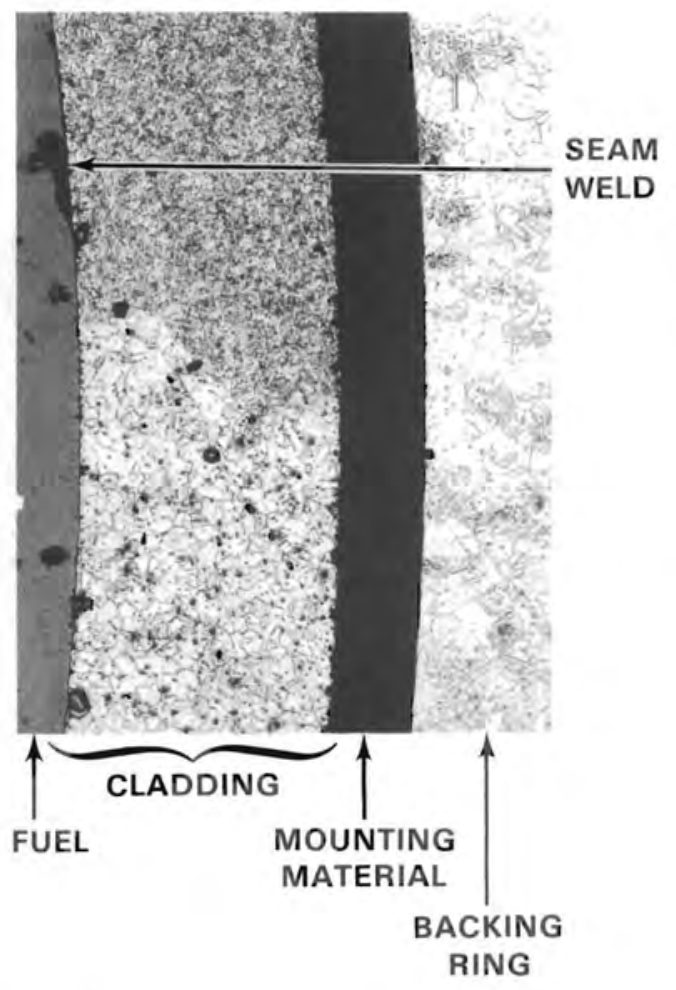

HC49855

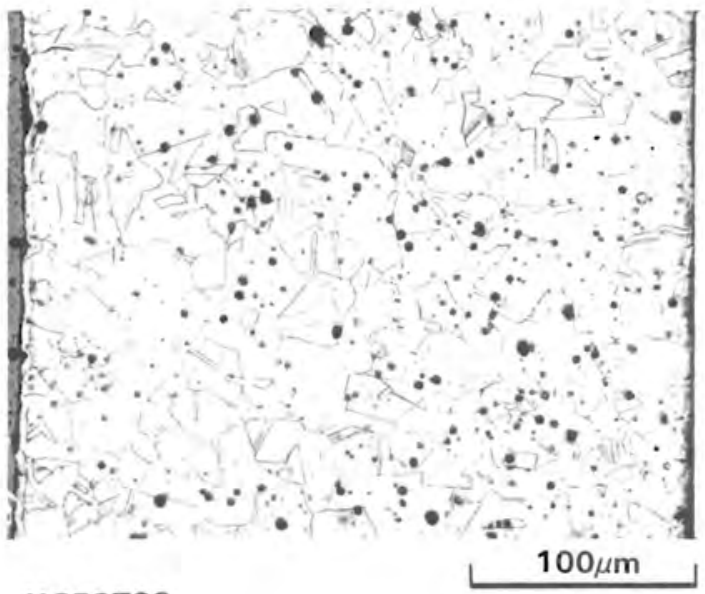

HC50798

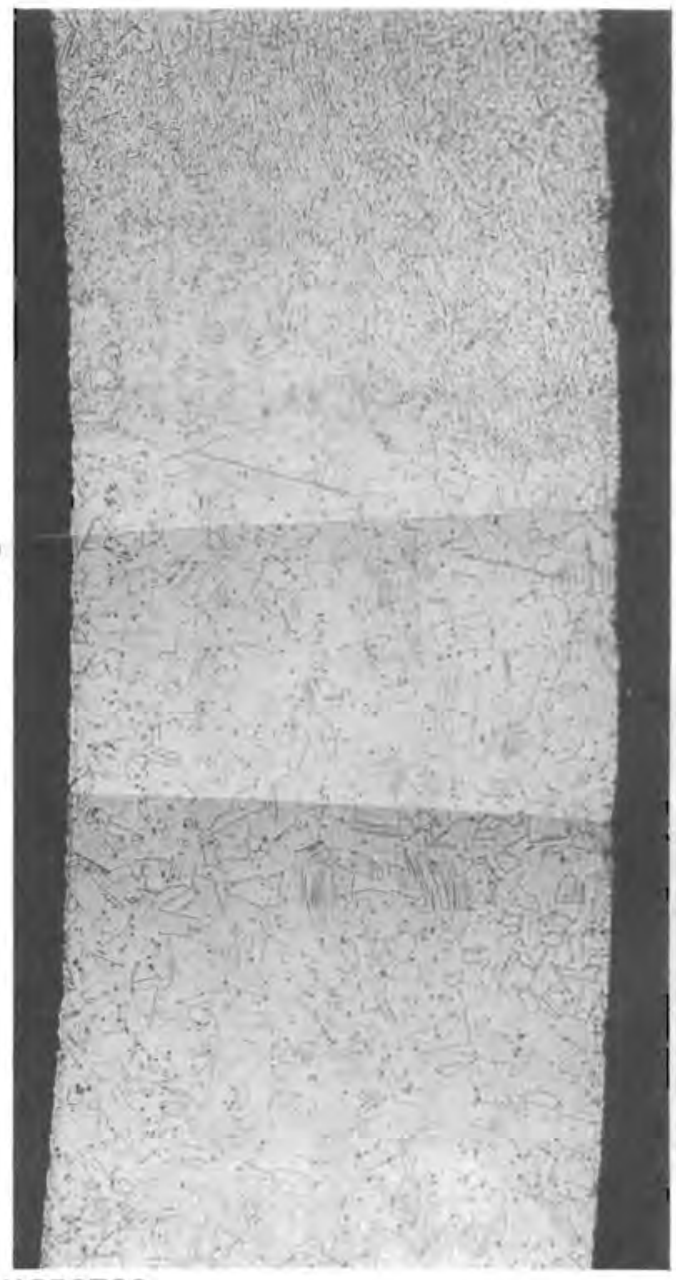

HC50780

HC50797

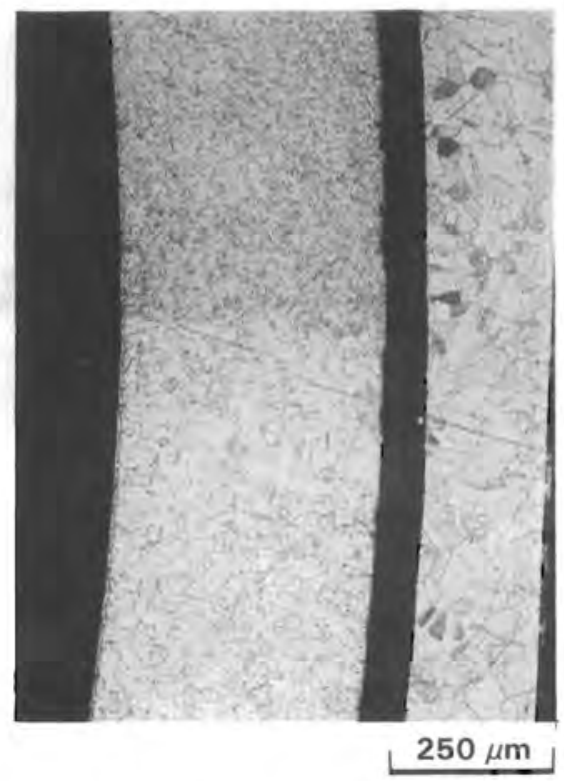

HC50799

FIGURE 35. Metallography of Surface Condition of Fuel Rods from Connecticut Yankee Fuel Assemblies G11 and H07 (Transverse Sections; Oxalic Acid Etchant) 


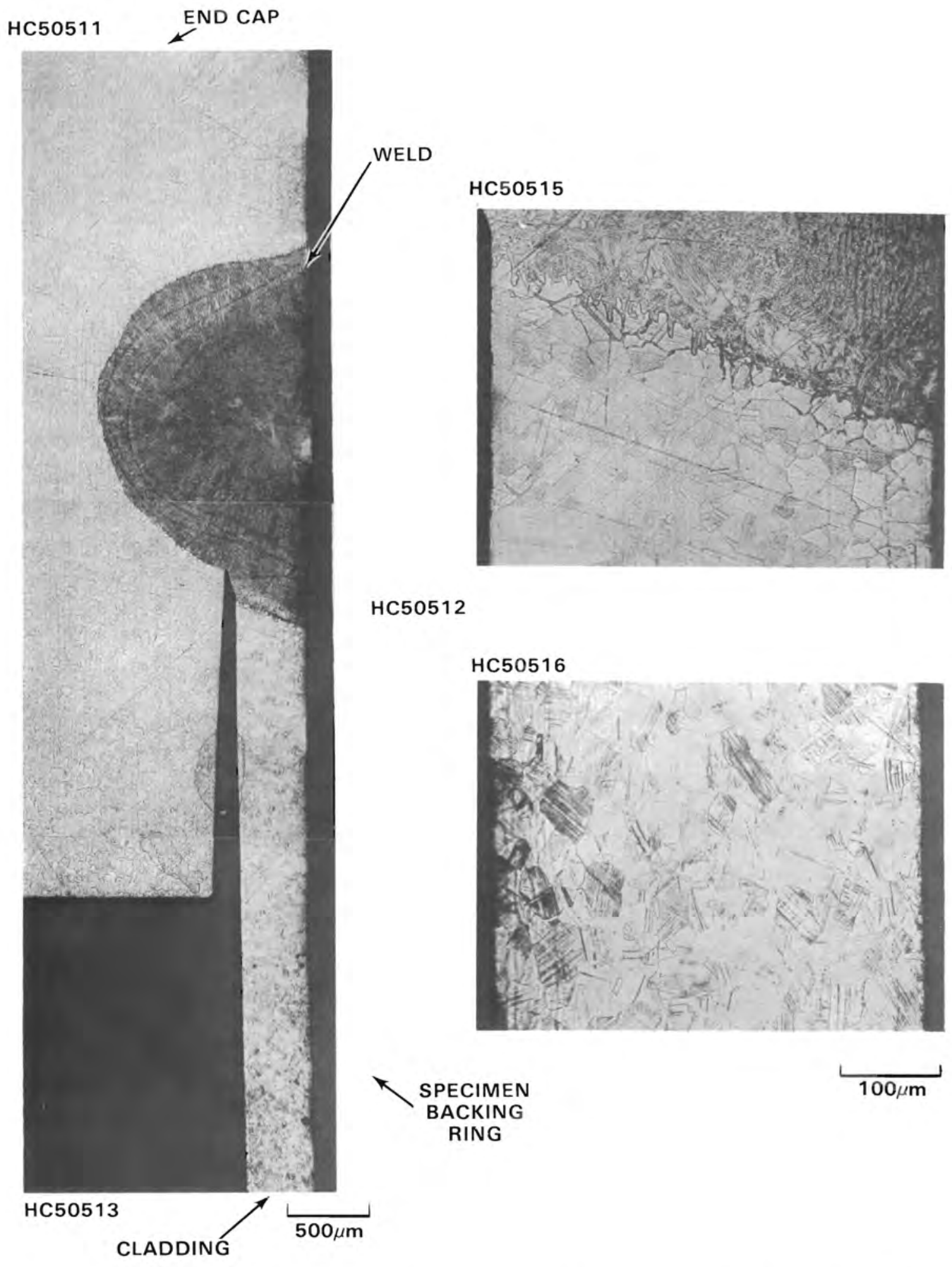

FIGURE 36. Metallography of Weld Area of Upper End Cap from S004 Fuel Rod ABG (Longitudinal Section; Oxalic Acid Etchant) 


\section{HC50815}
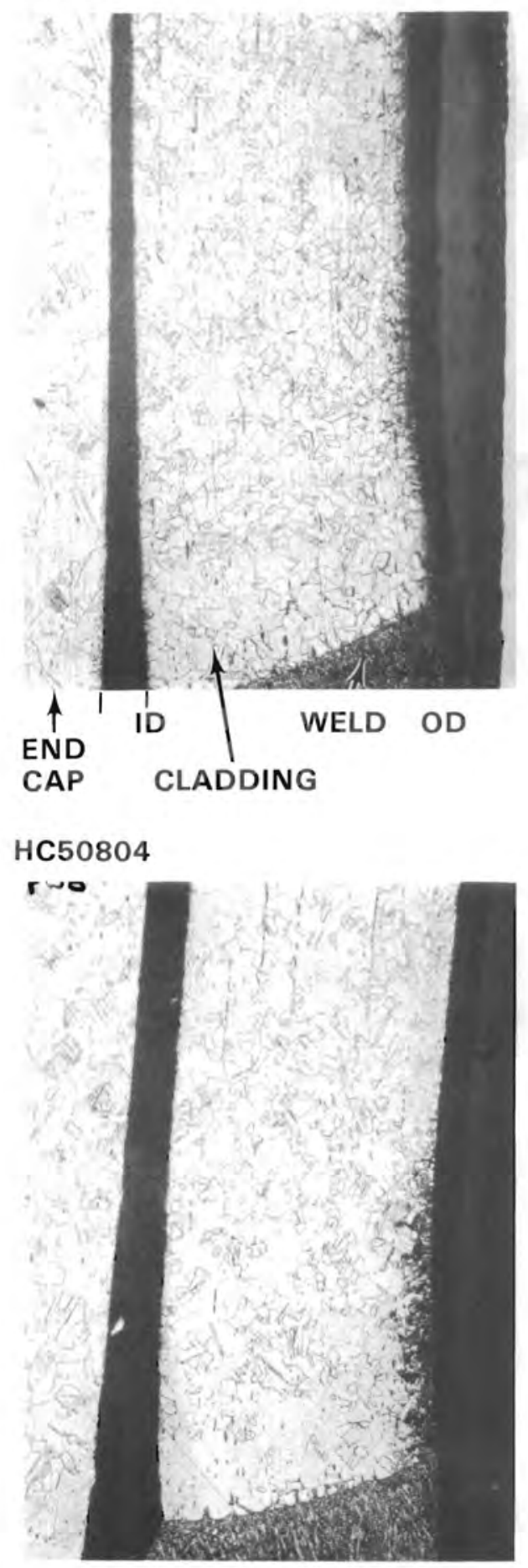

HC50816

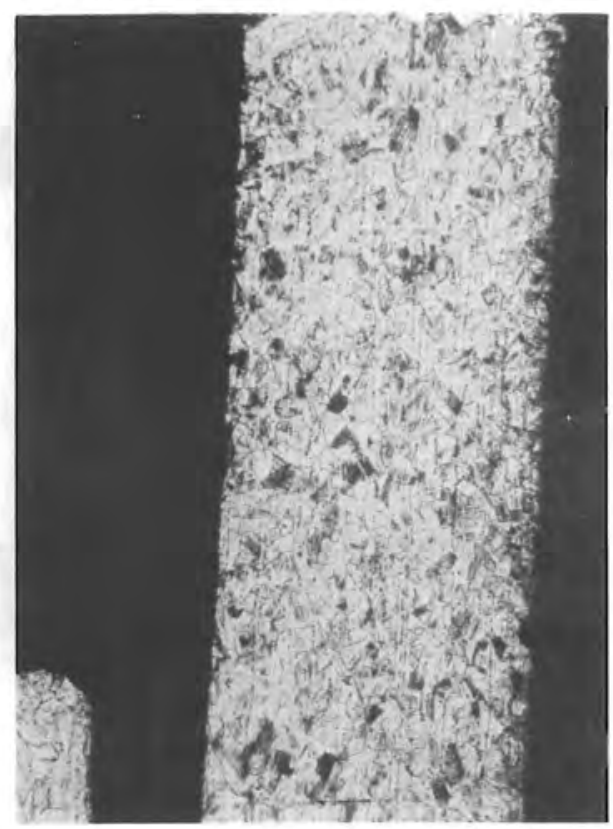

HC50810

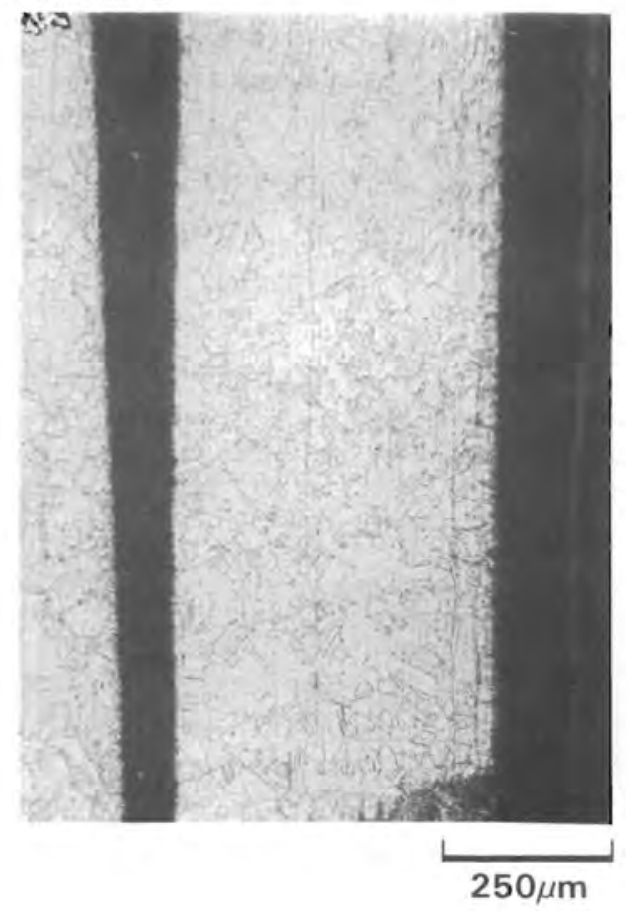

FIGURE 37. Metallography of Cladding Adjacent to Lower End Cap Welds from Connecticut Yankee Fuel Rods (Longitudinal Section; Oxalic Acid Etchant) 


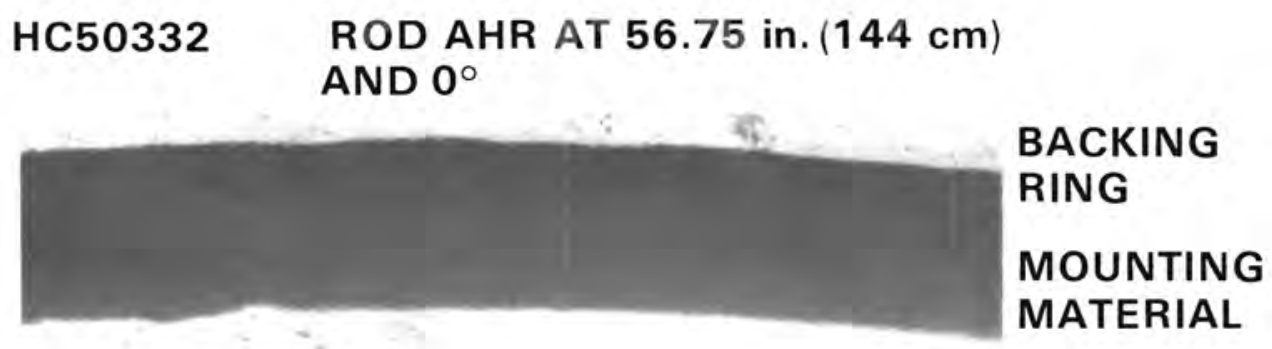

CLADDING

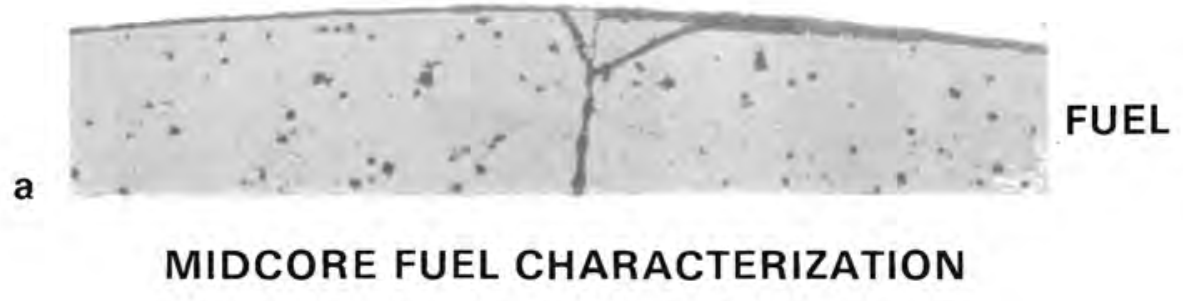

HC50333 ROD AHR AT 56.75 in. $(144 \mathrm{~cm})$ AND $90^{\circ}$

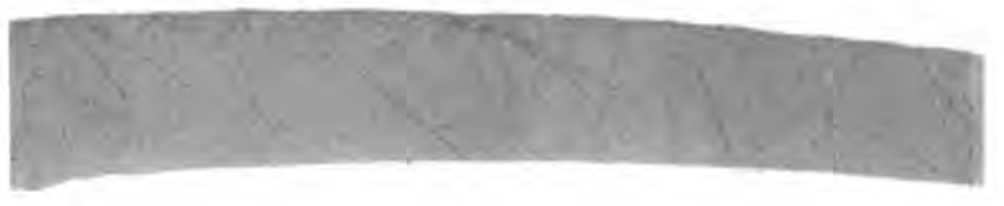

b

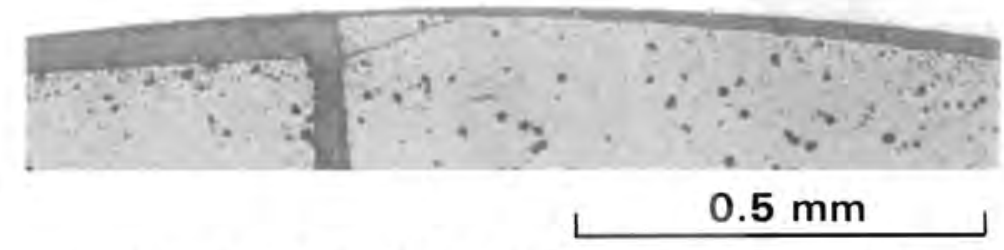

MIDCORE FUEL CHARACTERIZATION

FIGURE 38. Typical As-Polished Transverse Sections of Cladding and Fuel from Rod AHR Showing the Clean Cladding Interior and Exterior Surfaces, i.e., Free of Measurable Crud or 0xide (or Other Reaction) Layers 


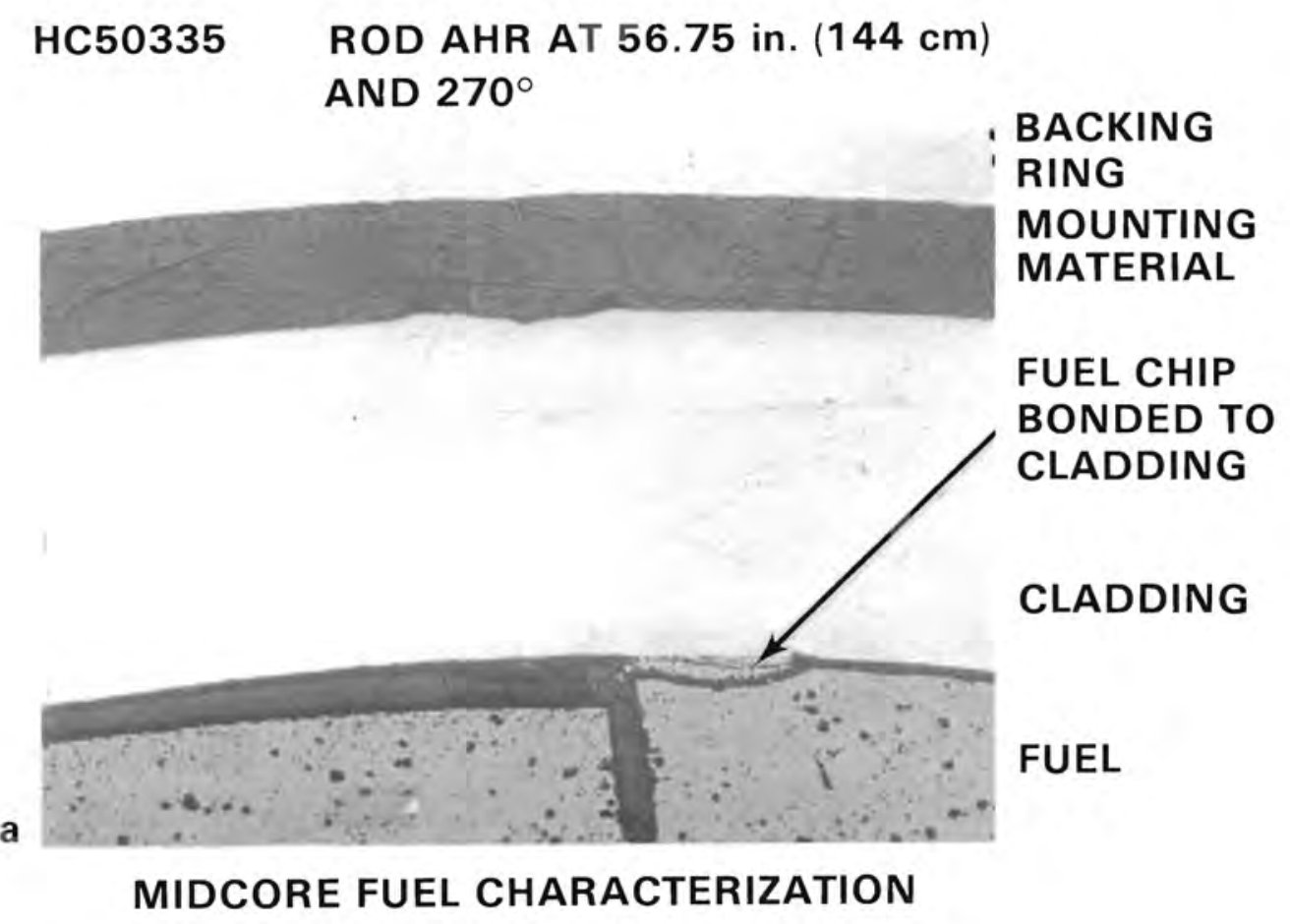

HC 50337 ROD AHR AT $80.50 \mathrm{in.}(204 \mathrm{~cm})$ AND $0^{\circ}$

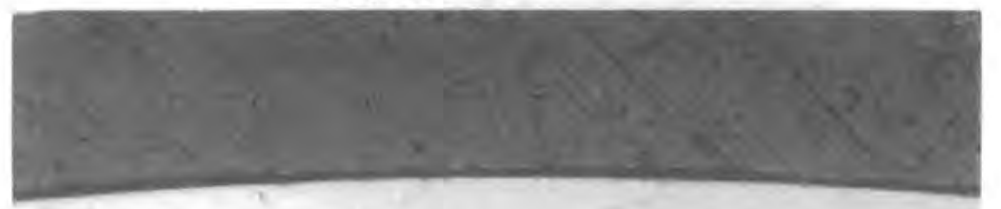

b

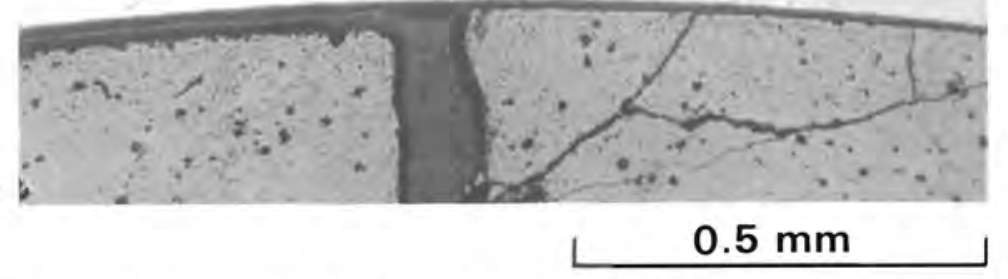

SECTION UNDER 3rd GRID SPACER FROM TOP

FIGURE 39. Typical As-Polished Transverse Sections of Cladding and Fuel from Rod AHR Showing the Clean Cladding Interior and

Exterior Surfaces, i.e., Free of Measurable Crud or Oxide (or Other Reaction) Layers 
HC50353 ROD AHR AT 98.25 in. $(250 \mathrm{~cm})$

AND $270^{\circ}$
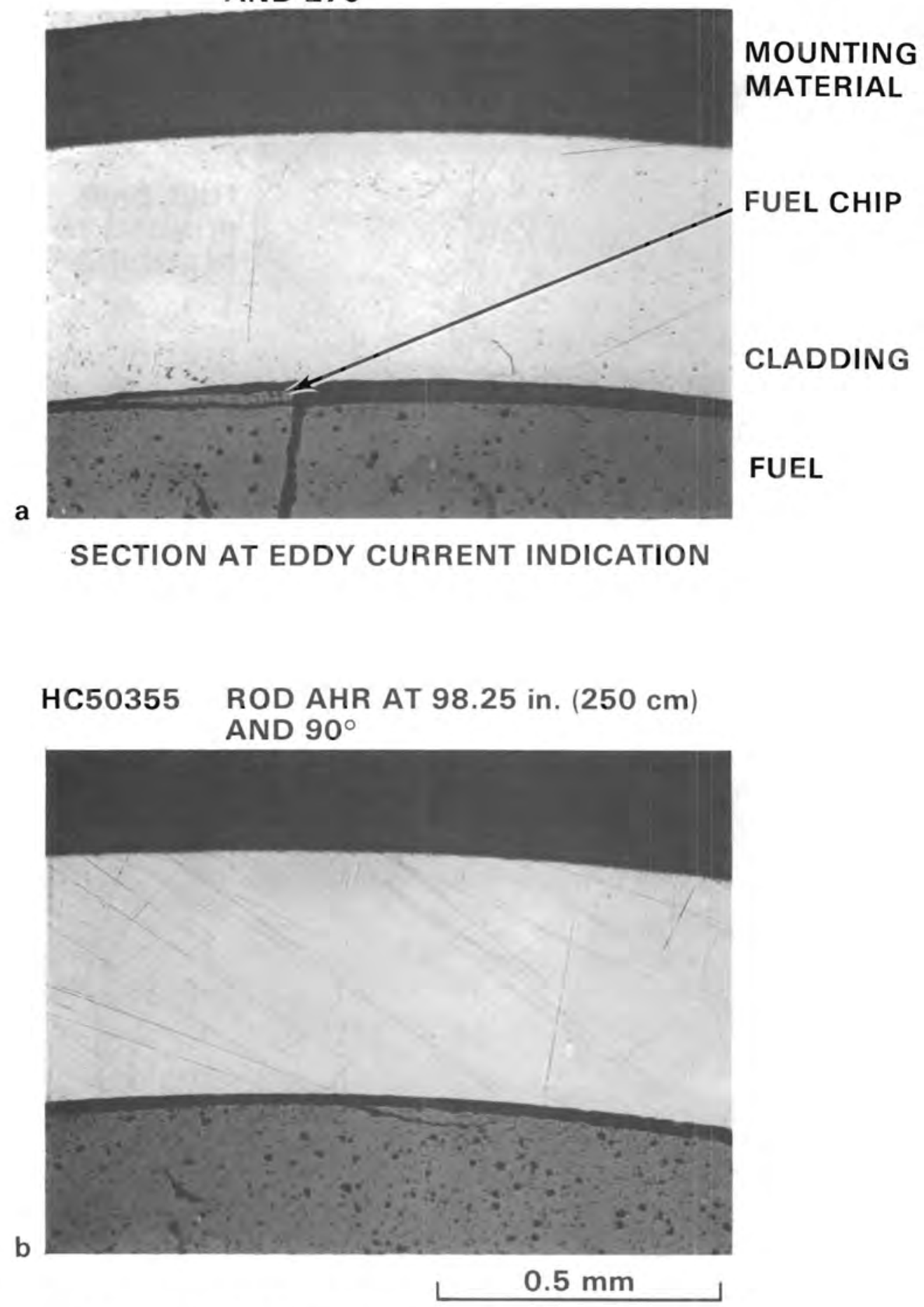

SECTION AT EDDY CURRENT INDICATION

FIGURE 40. Typical As-Polished Transverse Sections of Cladding and Fue 1 from Rod AHR Showing the Clean Cladding Interior and Exterior Surfaces, i.e., Free of Measurable Crud or oxide (or Other Reaction) Layers. The fuel chip in the upper photograph is much smaller than the chips observed in fuel rods from assembly $\mathrm{H} 07$. 

HC50342 ROD ABG AT $56.75 \mathrm{in.}(144 \mathrm{~cm})$
AND $0^{\circ}$

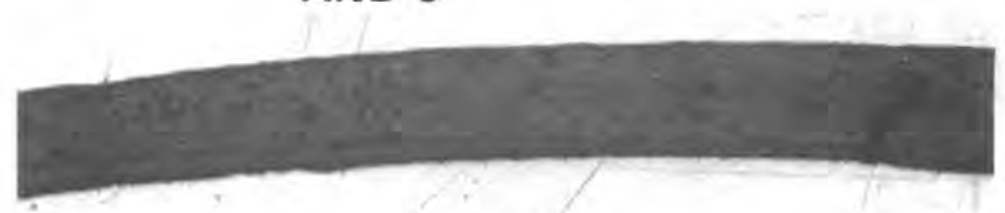

BACKING

RING

MOUNTING

MATERIAL

\section{CLADIDING}

a

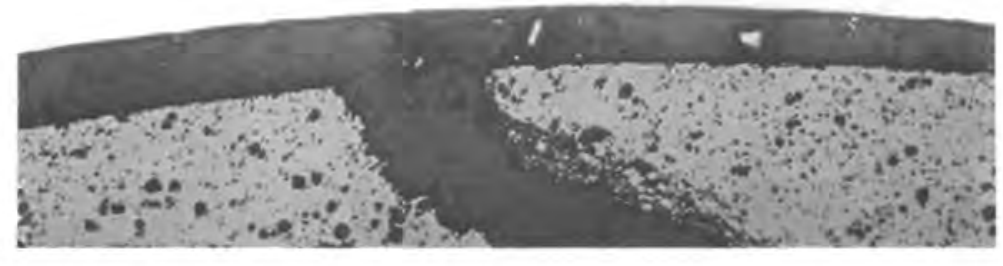

FUEL

HC50344 ROD ABG AT 56.75 in. (144 cm) AND $180^{\circ}$

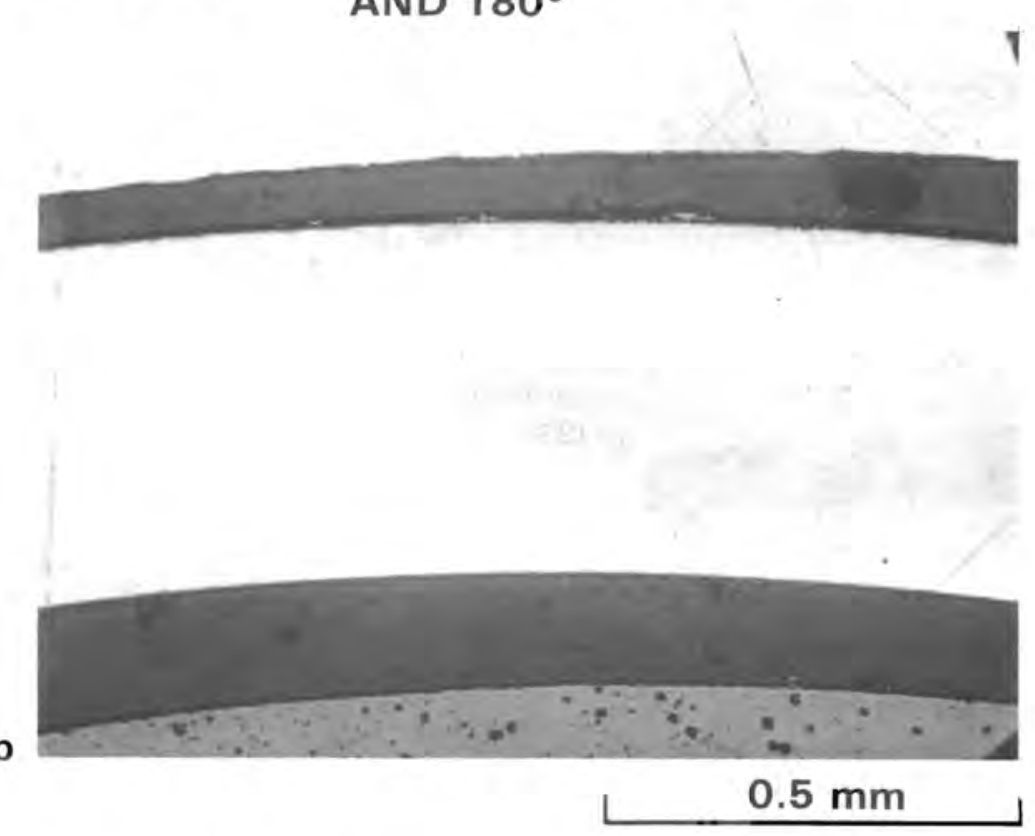

FIGURE 41. Typical As-Polished Transverse Metallographic Sections of Cladding and Fuel from Rod ABG Showing the Essentially Clean Cladding Interior and Exterior Surfaces, i.e., Free of Measurable Crud or Oxide Layers 


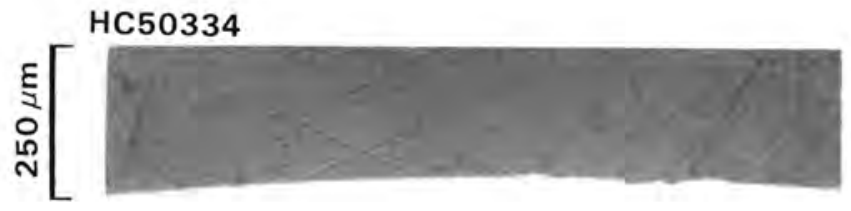

56.75 in. $(144 \mathrm{~cm})$

ABOVE ROD BOTTOM

AT $180^{\circ}$ AZIMUTHAL

POSITION (A.P.)

FUEL ROD AHR

FROM ASSEMBLY S004
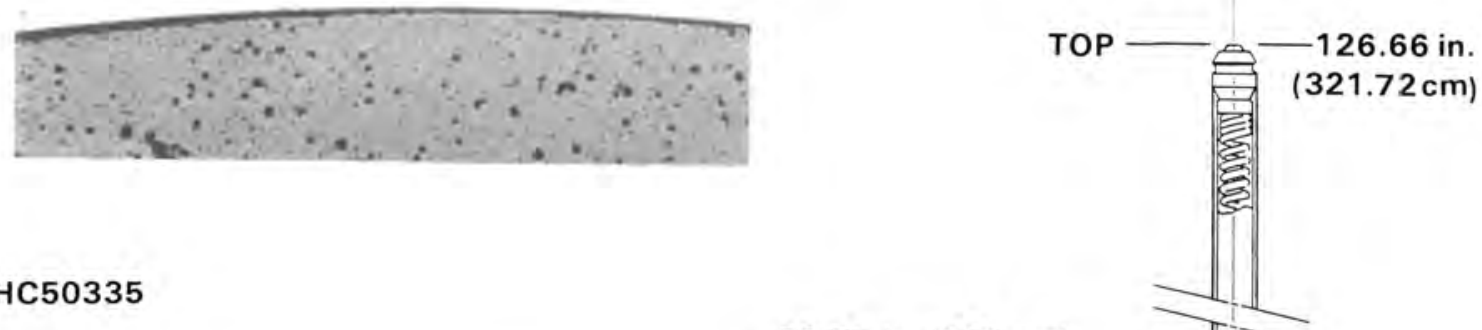

HC50335

56.75 in. $(144 \mathrm{~cm})$ ABOVE ROD BOTTOM

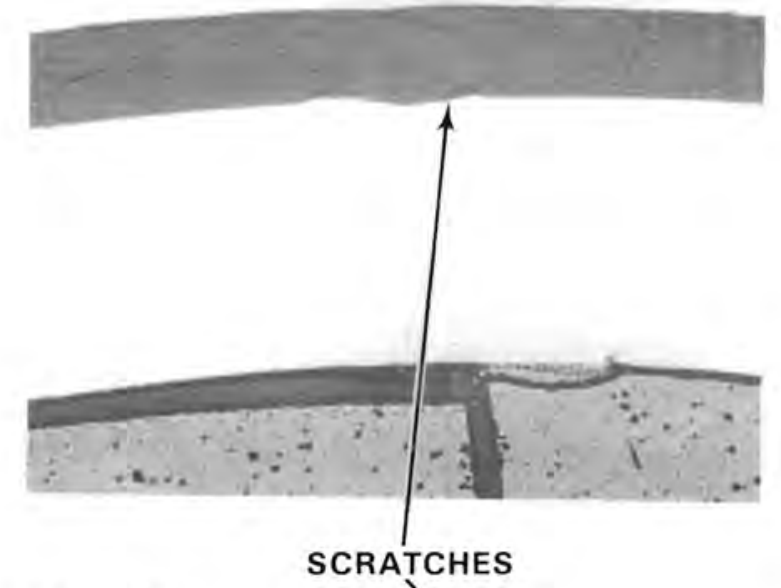
AT $270^{\circ}$ A.P

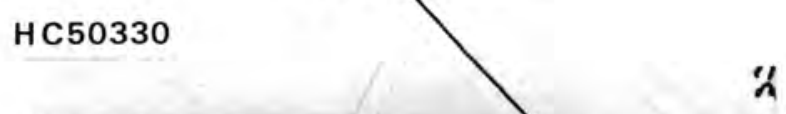

36.50 in. $(93 \mathrm{~cm})$ ABOVE ROD BOTTOM AT $270^{\circ}$ A.P.

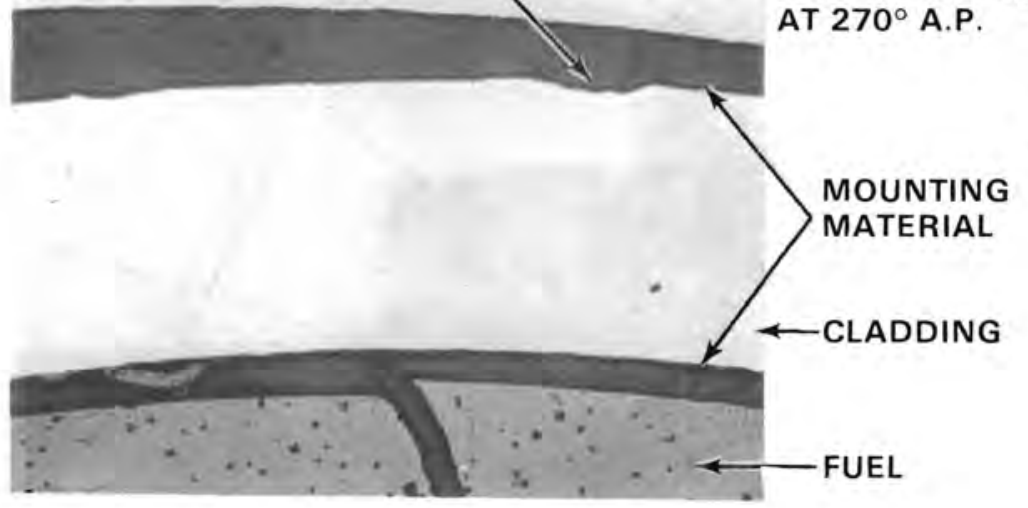

BOTTOM- 0 in.

AXIAL LOCATION

FIGURE 42. As-Polished Transverse Metallographic Sections of Fuel Rod AHR from Assembly S004 Showing Axial Scratches 
HC50796 (ROD 217E02 FROM H07)

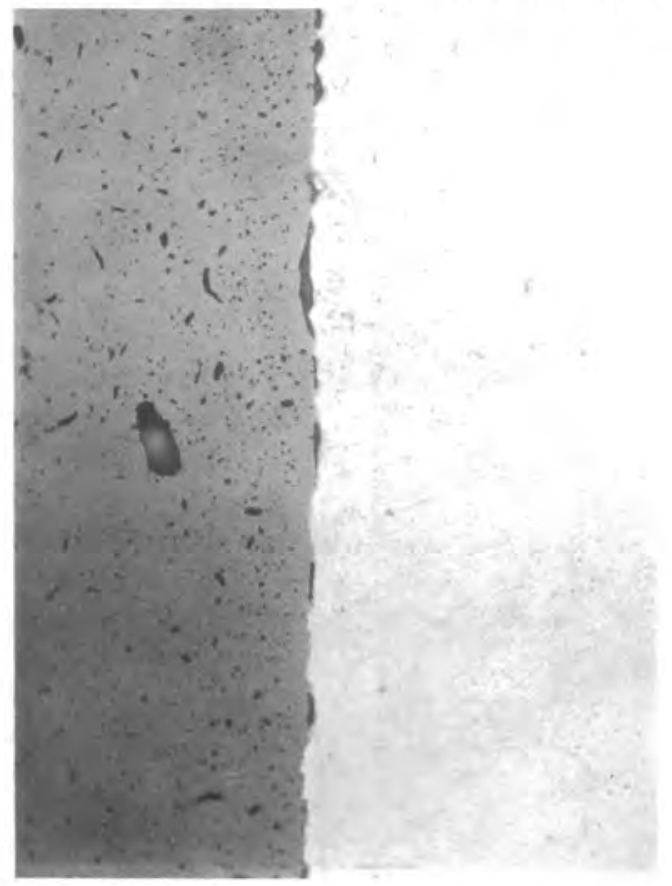

HC50782(ROD 595A10 FROM G11)

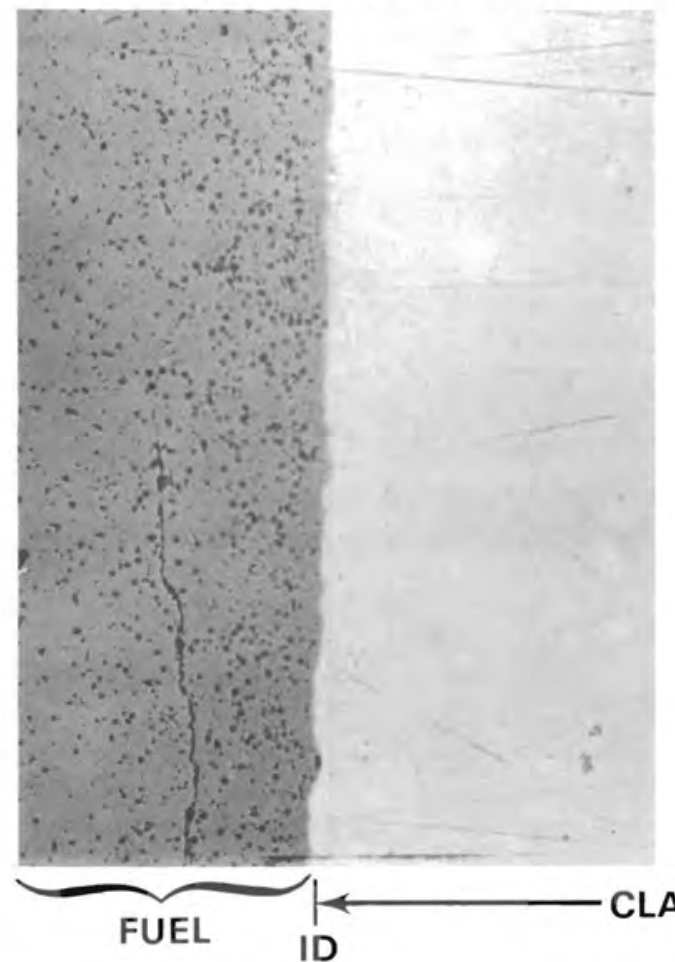

HC50795 (ROD 217E02 FROM H07)

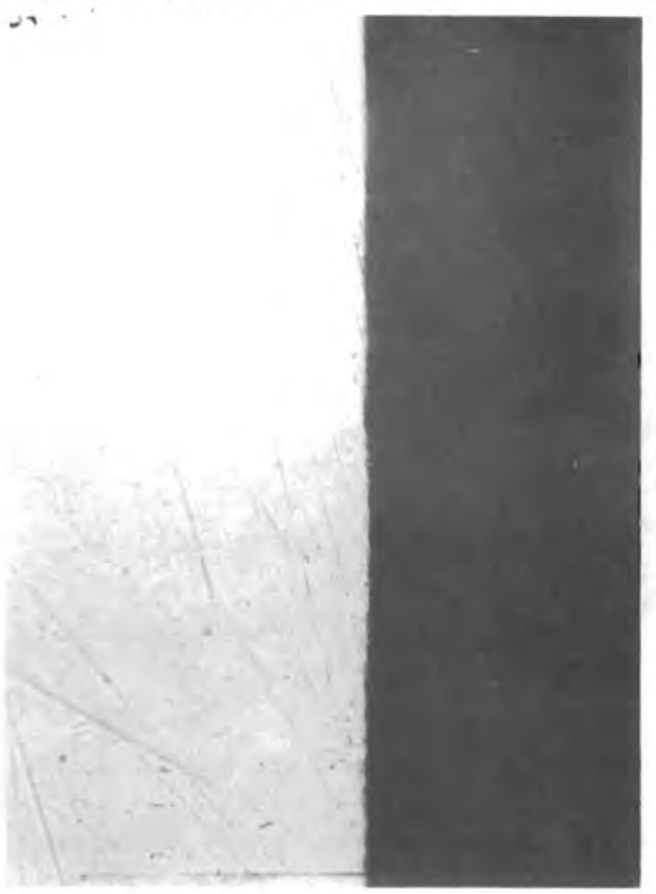

HC50780 (ROD 595A10 FROM G11) $-1$

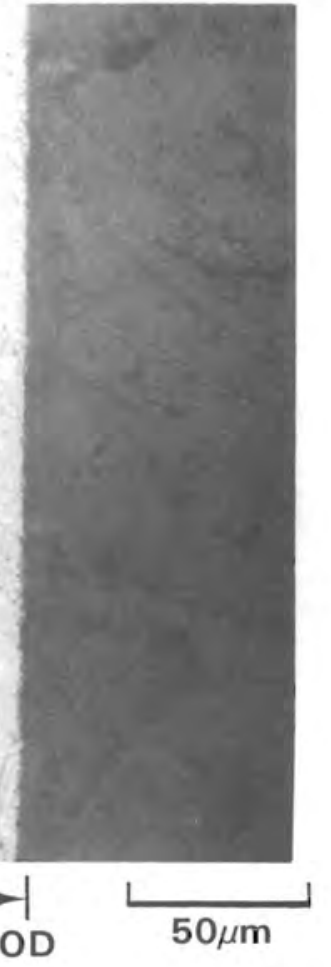

FIGURE 43. Metallography of ID and OD Surface Condition of Cladding from Connecticut Yankee Fuel Rods 


\section{HC50386 270}

$\stackrel{\infty}{\perp}$

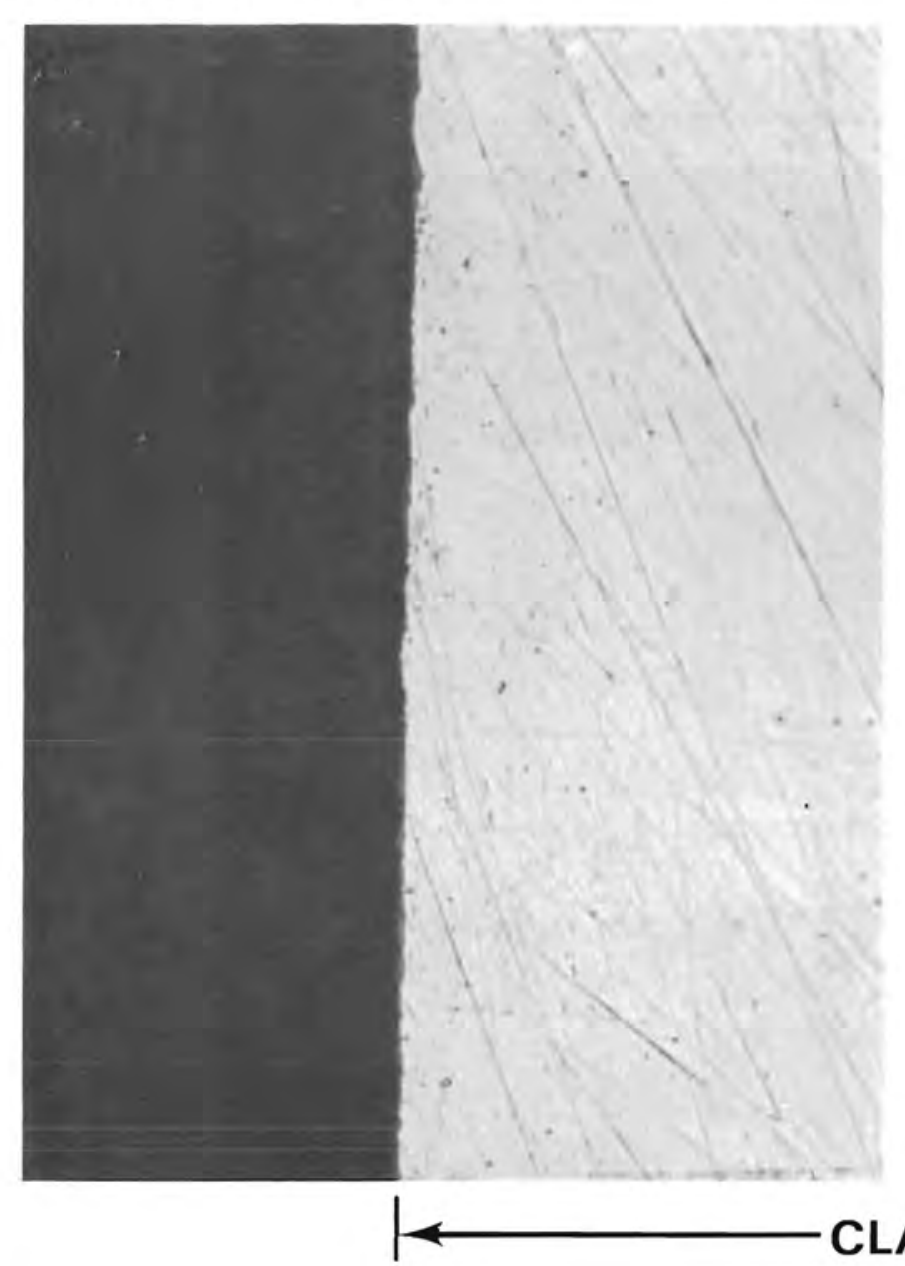

TYPICAL OD SURFACE

\section{HC50385 $270^{\circ}$}

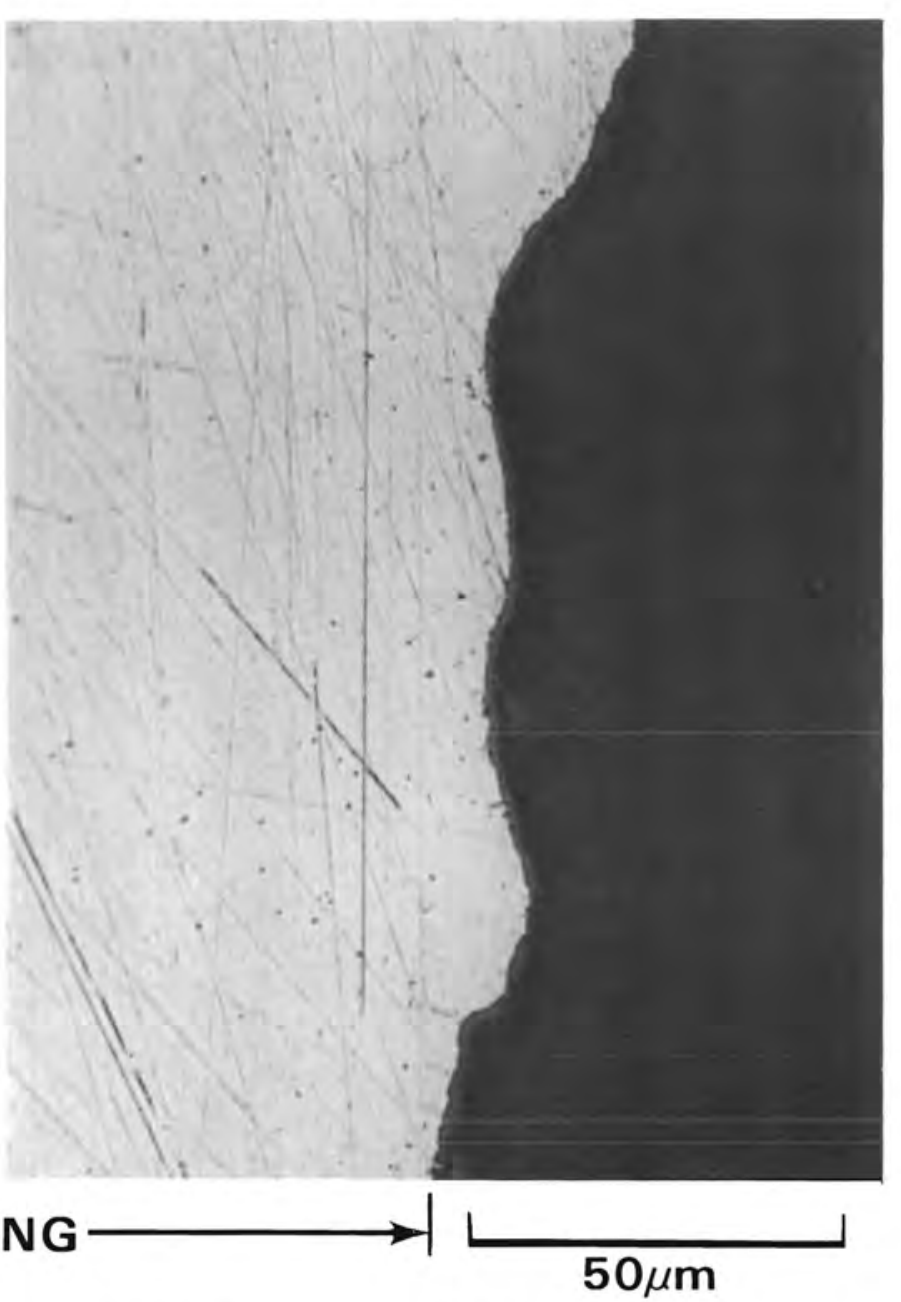

ATYPICAL OD SURFACE

FIGURE 44. Surface Condition of Cladding OD from S004 Fuel Rod ABG at 41.50 in. $(105 \mathrm{~cm})$ Above the Bottom of the Rod. (a) Typical cladding exterior surface, smooth, free of surface layers. (b) Gouged area, typical of handling marks or the axial scratches caused by gridspacer springs when rods are inserted into or withdrawn from the fuel assembly. 


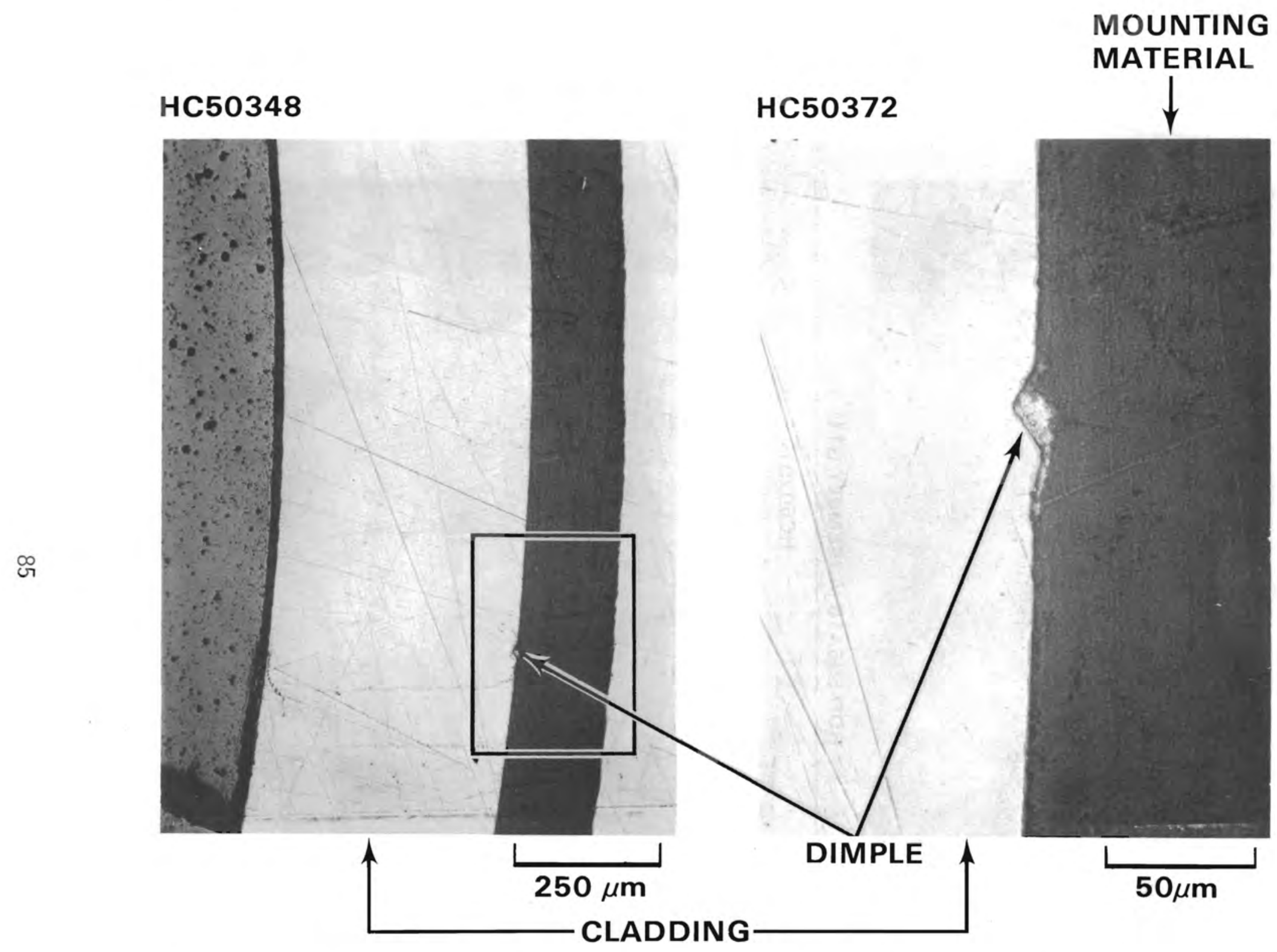

FIGURE 45. Metallography of Grid Spacer Dimple on Cladding OD from S004 Fuel Rod AHR. This transverse section was $83.75 \mathrm{in.}(213) \mathrm{cm}$ above rod bottom at $90^{\circ}$ azimuthal position. 
ROD 217E02 (ASSEMBLY H07)

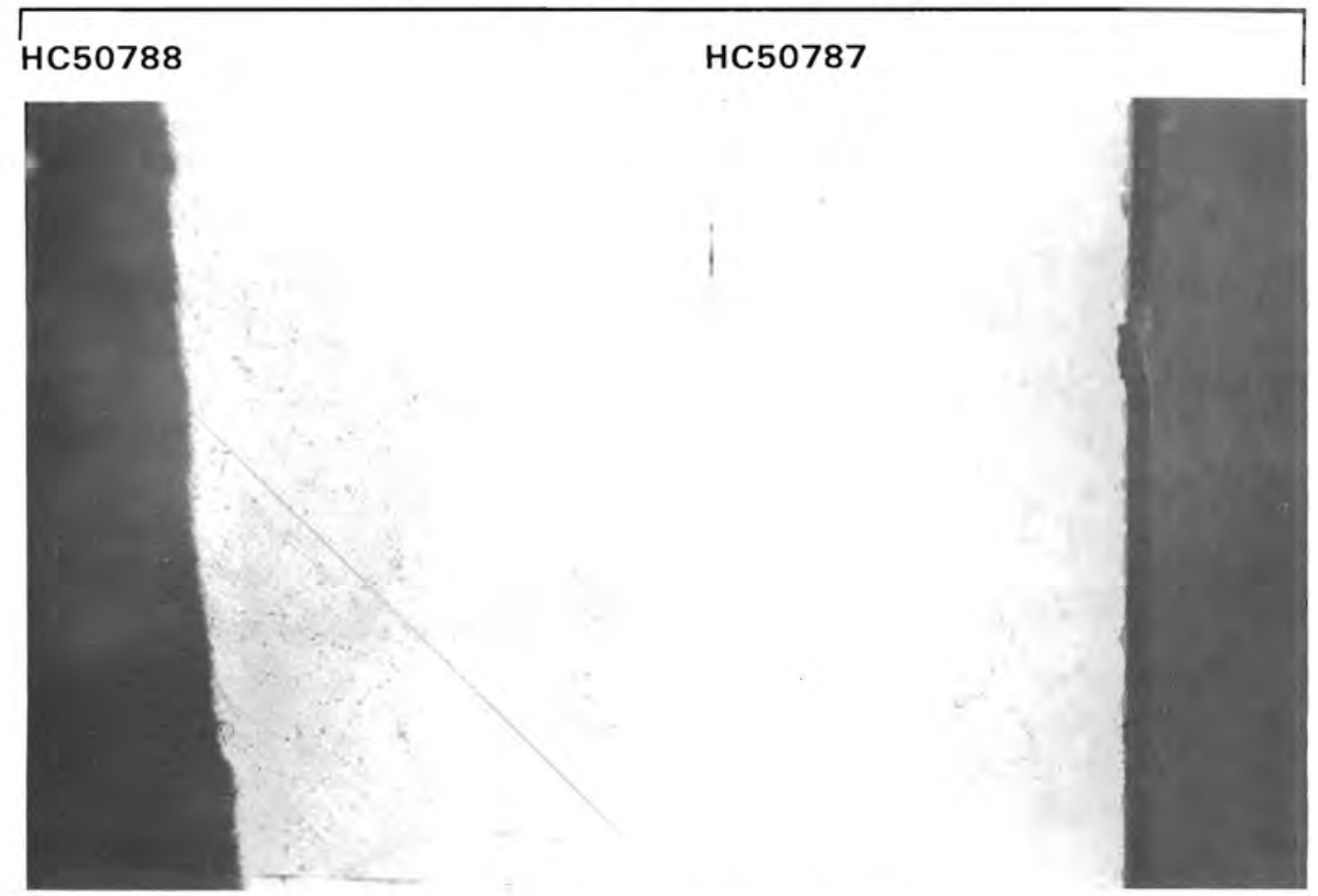

ROD 595A10 (ASSEMBLY G11)

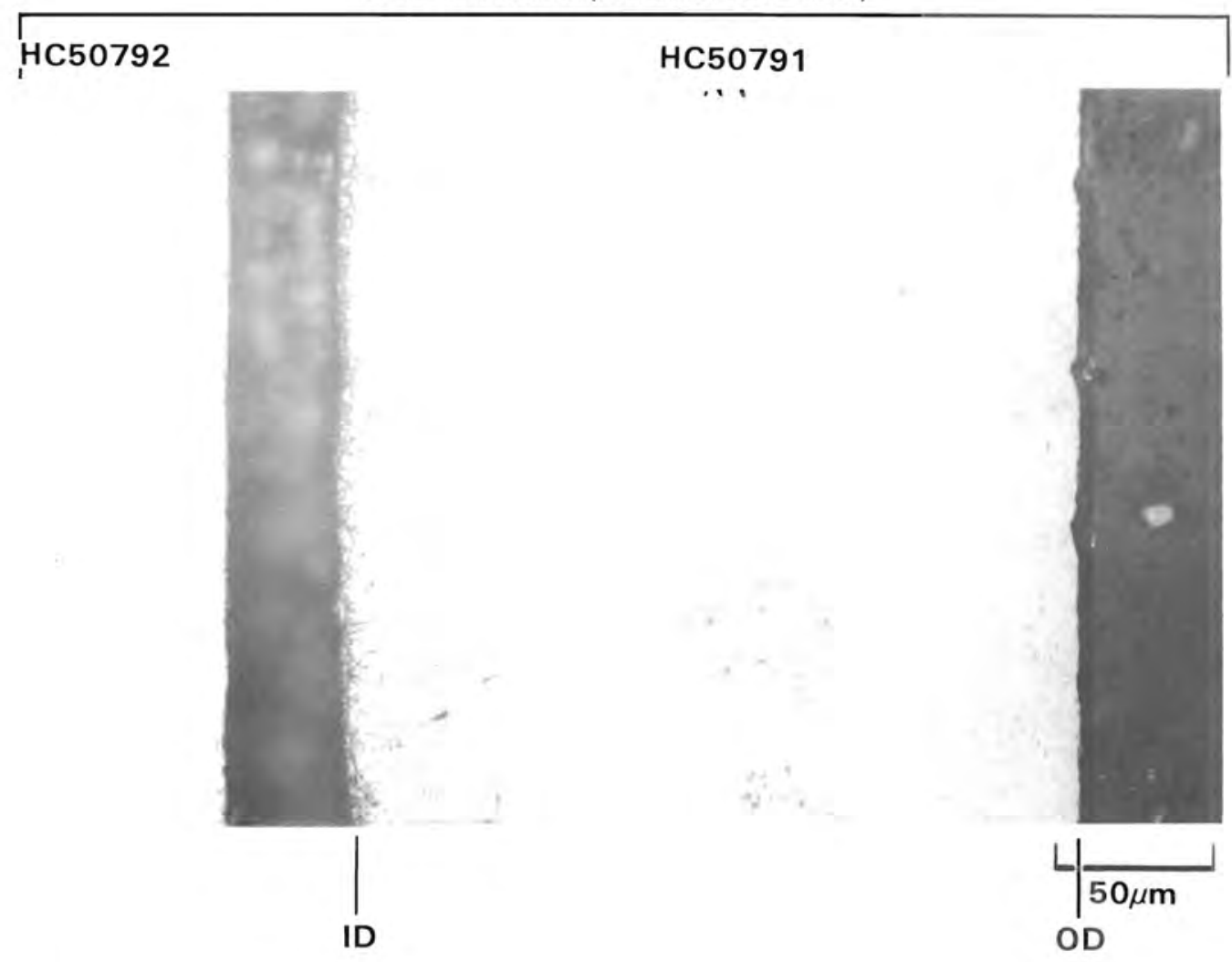

FIGURE 46. Metallography of ID and OD Surface Condition of Cladding from Connecticut Yankee Fuel Rods Near the Lower End Cap 


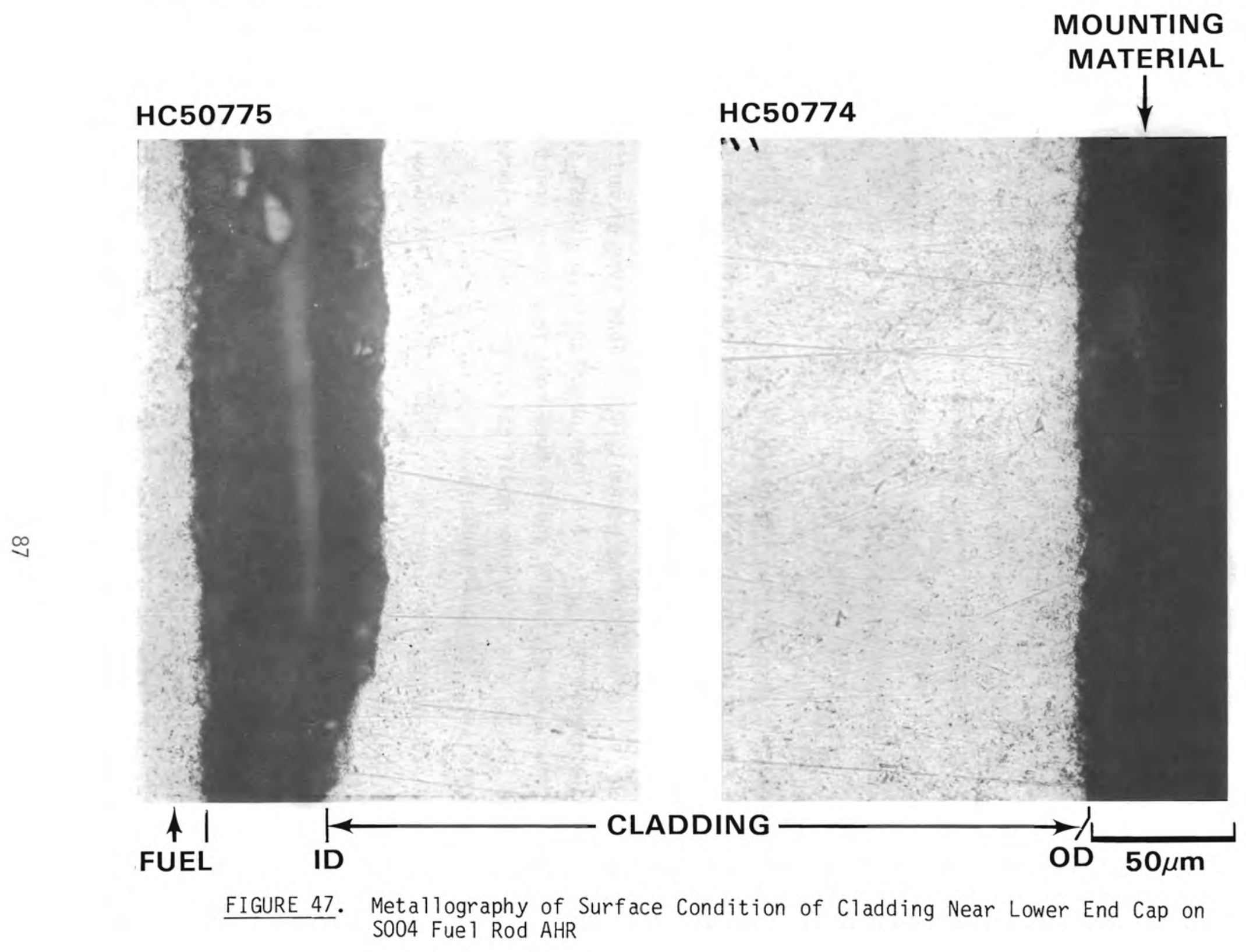


Metallography also revealed two distinct and urrelated types of surface layers on a few samples (Table 26). A darker gray layer occurred on the 00 of some samples in the as-polished condition. A metallic layer of the same color as the cladding but with a different microstructure occurred on the cladding ID of a few samples in the etched condition. Another gray layer was detected at the fuel-cladding interface in a failed fuel rod that contained water.

Photomicrographs showed continuous layers of a darker gray substance on the cladding OD in a few local areas on S004 rods AHR (Figures 44 and 48) and ABG (Figures 34 and 45 ). Figure 49 shows surface layers in a region where a surface deposit was visible during the visual examination in the $270^{\circ}$ orientation (see Figure 50). One area in the lower end cap from HO7 rod 217 EO2 (Figure 46) showed an intermittent surface layer on the cladding ID.

The interior surfaces of the cladding from the two 5004 rods were clean, i.e., no apparent degradation was caused by fission product attack or by oxidation. However, fuel rods from assembly GII and assembly HO7 (see Figure 35) did show a modified structure on the inner surface of the cladding. As in Figure $35(d)$, that modified structure on the cladding inner surface extends over the seam weld area, indicating that the effects of environment on the weld metal are metallurgically similar to the effects the base metal. Figure 51 is a view of the modified structure at higher magnification. A similar modified structure was noted in rod 595A10 from assembiy G11. This type of modified structure on the cladding inner surfce has been observed in stainless steelclad BWR fuel (Rosenbaum et al. 1966) and in fuel rods from other reactors (Barney and Wenple 1958). The structure modification has been attributed to damage caused by recoiling fission fragments.

The $\mathrm{H} 07$ rod $013 \mathrm{E} 03$ had a gray layer at the fuel-cladding interface. The layer was observed only in a fuel rod that had failed and had absorbed water. It is likely that the gray layer is a reaction product layer associated with the presence of water. The metallic and gray layers appeared only in the highpower regions in the fue 1 rods examined. 
TABLE 26. Information on the Metallographic Examination of Fuel Rods from Connecticut Yankee Fuel Assemblies S004, H07, and G11

\begin{tabular}{|c|c|c|c|c|c|c|c|c|}
\hline $\begin{array}{c}\text { Thickness } \\
\text { of Layer on } \\
\text { Cladding } 00 \\
(\mu \mathrm{m})\end{array}$ & $\begin{array}{l}\text { Fuel } \\
\text { Assembly } \\
\text { No. } \\
\end{array}$ & $\begin{array}{l}\text { Fue } 1 \\
\text { Rod } \\
\text { No. }\end{array}$ & $\begin{array}{l}\text { Location } \\
\text { (in.) }\end{array}$ & $\begin{array}{l}\text { Face on } \\
\text { Metallographic } \\
\text { Specimen } \\
\end{array}$ & Magnification & $\begin{array}{l}\text { Specimen } \\
\text { Surface } \\
\text { Condition }\end{array}$ & Comments & $\begin{array}{c}\text { Negative } \\
\text { No. }\end{array}$ \\
\hline 0.5 & S004 & AHR & $\operatorname{LEC}^{(\mathrm{b})}$ & first & $500 x$ & Etched & Layer on cladding $O D$ & HC50139 \\
\hline 0.5 & SOO4 & AHR & $83-3 / 4$ & first & $500 x$ & AP & Layer on cladding $O D$ & HC50372 \\
\hline $3-5$ & SOO4 & ABG & LEC & first & $250 x$ & AP & Layer on cladding $O D$ & HC50366-69 \\
\hline $3-5$ & S004 & $A B G$ & $41-1 / 2$ & first & $750 x$ & AP & Layer on cladding $O D$ & HC50385 \\
\hline-- & H07 & 157E01 & -- & -- & -- & -- & No layer on cladding $O D$ was evident & -- \\
\hline 1 & H07 & 217E02 & LEC & -- & $500 x$ & AP & -- & HC50787 \\
\hline-- & G11 & $595 A 10$ & -- & -- & -- & -- & No layer on cladding $O D$ was evident & -- \\
\hline \multicolumn{9}{|l|}{$\begin{array}{c}\text { Thickness } \\
\text { of Layer on } \\
\text { Cladding ID, } \\
(\mu \mathrm{m})\end{array}$} \\
\hline-- & S004 & $A B G$ & -- & -- & -- & -- & No layer on cladding ID was evident & -- \\
\hline -- & H07 & 013E03 & 27 & - & $500 x$ & Etched & Gray layer on fue $10 D$ & HC50454 \\
\hline $\begin{array}{l}-- \\
--\end{array}$ & $\begin{array}{l}\mathrm{HO7} \\
\mathrm{H} 07\end{array}$ & $\begin{array}{l}013 \mathrm{E} 03 \\
013 \mathrm{E} 03\end{array}$ & $\begin{array}{l}78-1 / 4 \\
79\end{array}$ & $\begin{array}{l}-- \\
--\end{array}$ & $\begin{array}{l}7 x \\
7 x\end{array}$ & $\left.\begin{array}{l}A P \\
A P\end{array}\right\}$ & $\begin{array}{l}\text { Thin gray layer part way around } \\
\text { circumference of fuel pellet. }\end{array}$ & $\begin{array}{l}\text { HC50248 } \\
\text { HC50287 }\end{array}$ \\
\hline 6 & H07 & $157 \mathrm{E} 01$ & $35-13 / 16$ & -- & $250 x$ & Etched & Cladding ID had modified structure (thin) & HC49855 \\
\hline 5 & H07 & $157 \mathrm{E} 01$ & $64-1 / 16$ & -- & $100 x$ & Etched & Cladding ID had modified structure (thin) & HC49910 \\
\hline-- & H07 & 217E02 & LEC & -- & -- & -- & No longer on cladding ID was evident & -- \\
\hline-- & H07 & 217E02 & $45-1 / 2$ & -- & $7 x$ & AP & Modified structure on cladding ID & HC50793 \\
\hline-- & $\mathrm{HO7}$ & 217E02 & $45-1 / 2$ & -- & $100 x$ & Ap & $\begin{array}{l}\text { Intermittent voids in layer at fuel-cladding } \\
\text { interface }\end{array}$ & HC50794 \\
\hline
\end{tabular}

(a) Inches above bottom end of fuel rod.

(b) Lower end cap (LEC).

(d) No entry. 
IABLE 26. (contd)

Thickness

of Layer on

Cladding ID

$(\mu \mathrm{m})$

$\begin{array}{cl}\text { Fue } 1 & \text { Fue } 1 \\ \text { Assembly } & \text { Rod }\end{array}$

Locatign

Face on

Specimen

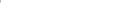

$\mathrm{HO7}$

$217 \mathrm{E02}$

$45-1 / 2$

Specimen

$\frac{\text { Magn if ication }}{500 x}$

Surface
Condition

3

H07 217E02 45-1/2

$100 x$

AP

$\frac{\text { Comments }}{\begin{array}{l}\text { Intermittent voids in layer at fuel-cladding } \\ \text { interface }\end{array}}$

Negative

HC50796

Cladding ID had modified structure that

HC50797

$1-2$

HO7 217E02 45-1/2

$--$

$200 x$

continued through weld area.

3 HO7 217E02 45-1/2

-- G11 595A10 LEC

$-$

G11

$595 A 10 \quad 44-3 / 4$

$-$

$500 x$

Etched

Cladding ID had modified structure

HC50798-800

$--$

$--$

$100 x$

Cladding ID had modified structure

HC50801

-- No layer on ID was evident

$-100 x$

Etched

Modified structure on cladding ID

HC50820

Modified structure on cladding ID

HC50824

Fuel Chips

Adhering to

$\begin{array}{llllll}\text { Yes } & & \text { S004 } & \text { AHR } & 56-3 / 4 & -- \\ \text { Yes } & & \text { S004 } & \text { AHR } & 56-3 / 4 & -- \\ \text { Yes } & & \text { S004 } & \text { AHR } & 80-1 / 2 & -- \\ \text { No } & & \text { S004 } & \text { ABG } & -- & -- \\ \text { No } & & \text { H07 } & 013 E 03 & -- & -- \\ \text { No } & & \text { H07 } & 157 \text { E01 } & 35-13 / 16 & -- \\ \text { No } & & \text { H07 } & 217 \text { E02 } & -- & -- \\ \text { Yes } & \text { G11 } & 595 A 10 & 44-3 / 4 & -- \\ \text { Yes } & \text { G11 } & 595 A 10 & 44-3 / 4 & --\end{array}$

Circumferential Cracking of

Only noted in

in high power

regions of

fuel rods

$\begin{array}{lll}7 \times & \text { AP } & -- \\ 100 x & \text { AP } & -- \\ 7 X & \text { Ap } & -- \\ -- & -- & -- \\ -- & -- & -- \\ 100 x & \text { AP } & -- \\ -- & -- & -- \\ 500 x & \text { AP } & -- \\ 500 x & \text { Etched } & --\end{array}$

HC50331

HC50335

HC50336

-.

HC49887

HC50400

HC50430

Circumferential cracking of $\mathrm{U}_{2}$ noted mostly -extent in Gll fuel rods, and not seen in $\mathrm{SOO}_{4}$ fuel rods. 


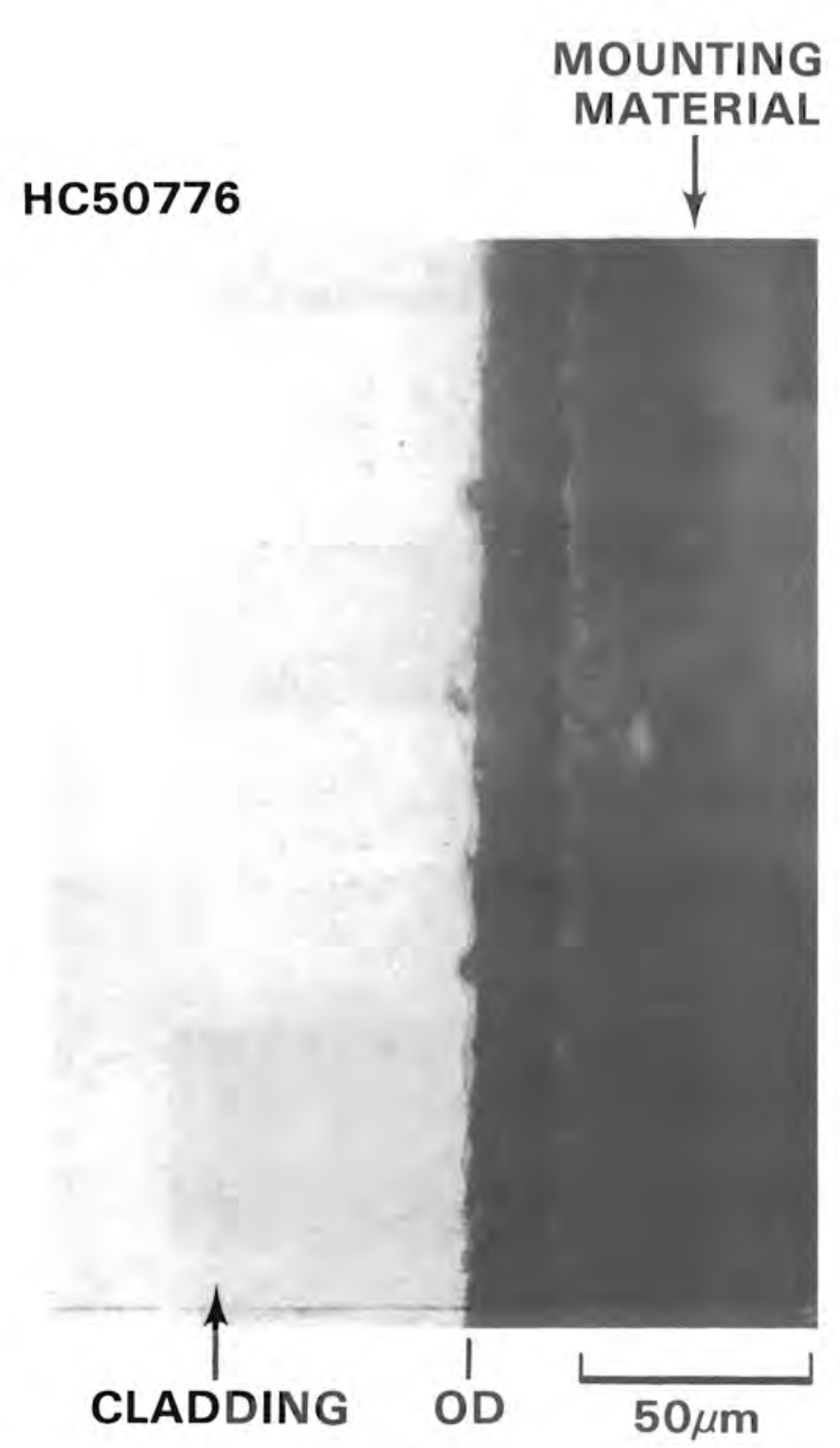

FIGURE 48. Metallography of Surface Layer on Cladding from S004 Fuel Rod AHR

Surface roughness occurred in localized areas on cladding outer surfaces and was attributed to the effects of fabrication or to fuel handling operations. The rough surfaces shown in Figure 49 occurred at or below the lower end cap weld, an area that had been machined to remove the weld flash. The rough surface shown in Figure 44 is associated with a surface scratch, 


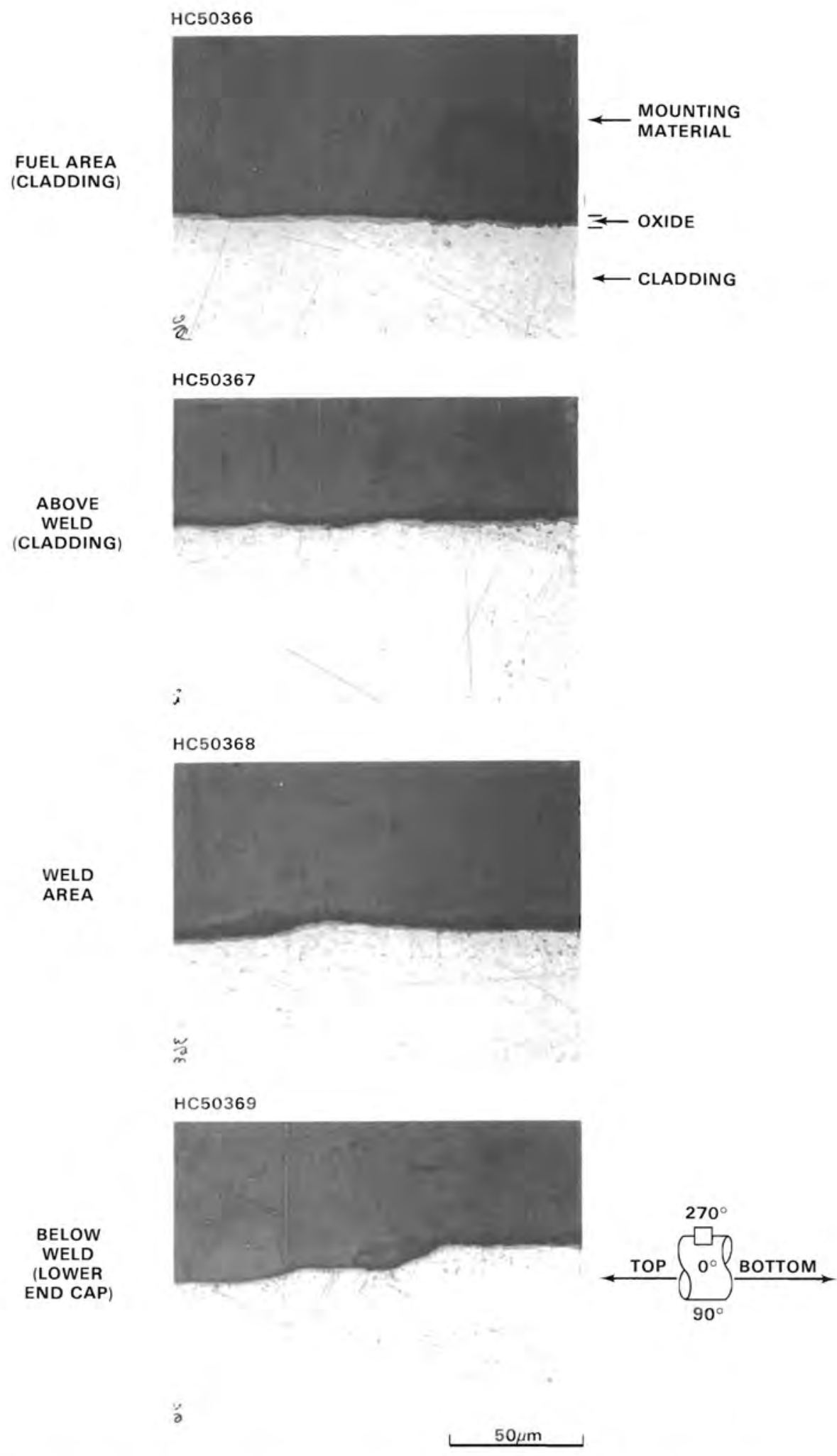

FIGURE 49. Meta1lography of Surface Layers at $270^{\circ}$ Near the Lower End Cap on the Cladding from Fuel Rod ABG from Assembly S004 

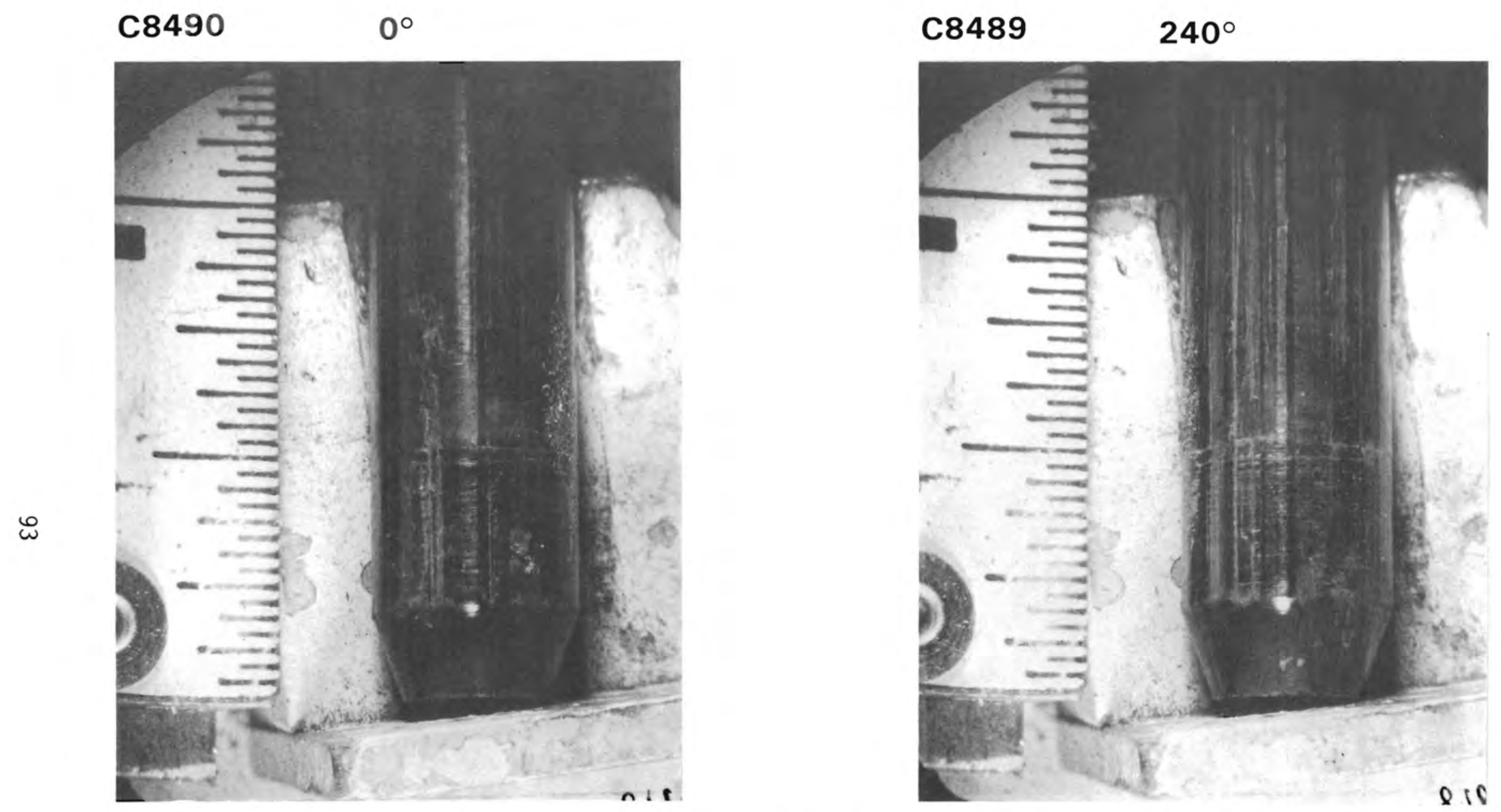

FIGURE 50. Surface Appearance of Lower End Cap Area of Fuel Rod ABG from Assembly S004 


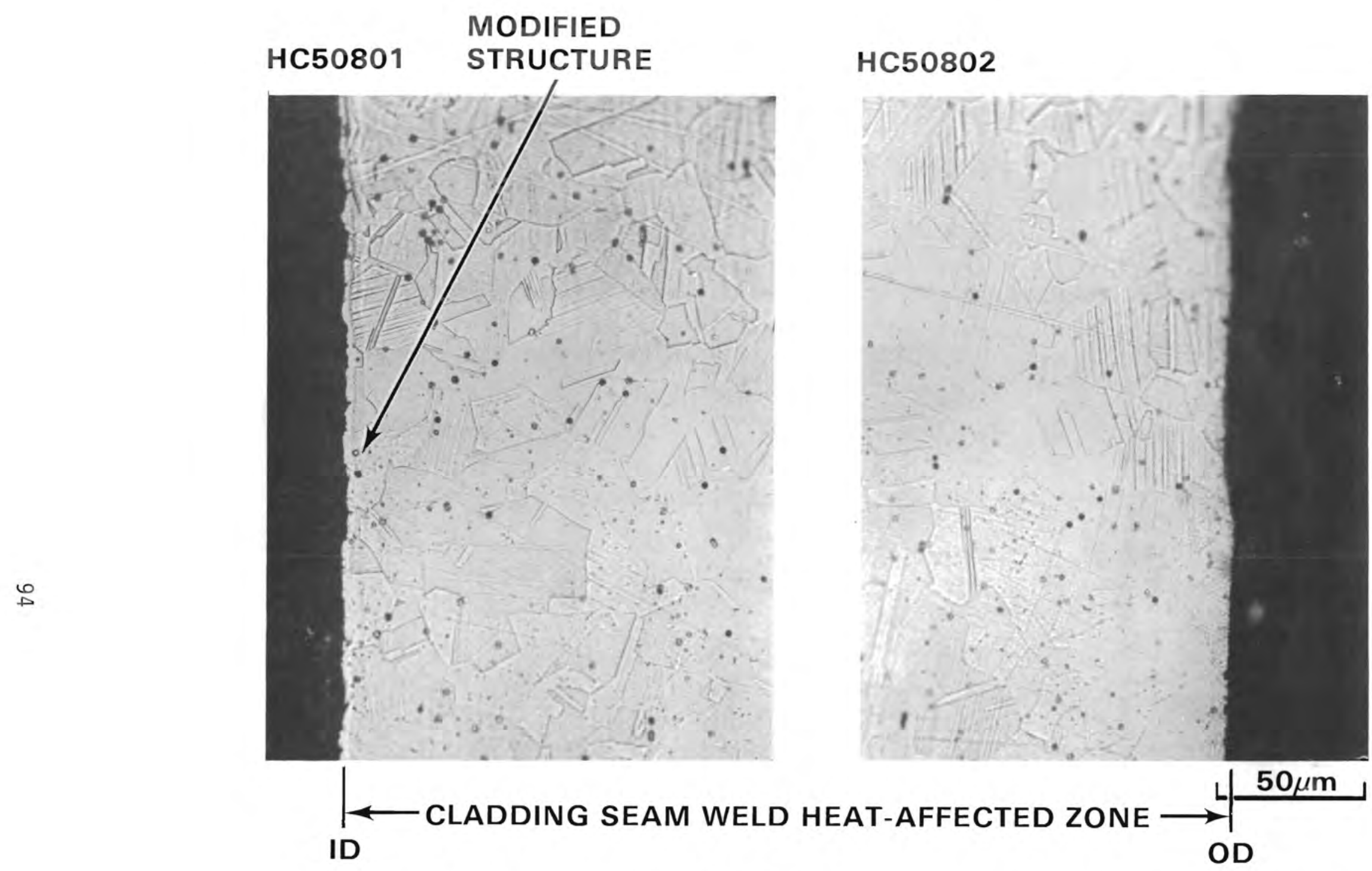

FIGURE 51. Surface Condition of Cladding from Connecticut Yankee Fuel Rod 217 E02 from Assembly $\mathrm{HO7}$ Including the Detail of Modified Structure on the Cladding ID. Transverse section, $45.50 \mathrm{in}$. $(116 \mathrm{~cm})$ above the bottom of the rod. 0xalic acid etchant used. 
probably a handling mark. In Figure 45, note a dimple formed in the cladding at a spacer grid spring contact apparently by fretting corrosion (see Figure 18 for visual examination results of a similar area). This is the extreme example observed of cladding surface damage caused by grid spacer contact. The depth of this dimple $(\sim 10 \mu \mathrm{m})$ was less than that of many handling marks.

The cladding thickness measurements in Table 27 were made from photographs of cladding in the as-polished condition at 100X magnification. The photographs were taken at $90^{\circ}$ intervals. Three measurements were made from each photograph. No significant reduction in cladding thickness was discernible compared to the original cladding thickness.

The weld area of S004 rod ABG at the upper end cap was seen earlier in Figure 36. Areas of recrystallization occur adjacent to the weld in the end cap material and in the cladding. This figure also showed the weld metal, heat-affected zone, and base metal structures at higher magnification. Figure 37 showed the similarity of the microstructure of the cladding from the three fuel assemblies, as well as the difference in etching behavior between the cladding in the weld HAZ and the more remote base metal. The difference in lower end cap weld geometry between the S004 rods and the G11 rods is evident in Figure 52.

Al1 structural and microstructural aspects of the welds in rods from the HO7 and G11 assemblies are similar except for the appearance of the HAZ in the G11 rod, which does not appear to have the intergranular weld metal penetration seen in the $\mathrm{HO}$ and S004 rods (see Figures 32, 33, and 37). The lower end cap welds in the S004 and $\mathrm{HOT}$ assemblies may have been made with a higher welding heat input resulting in some intergranular melting. Figure 34 illustrated the metallographic detail of the HAZ of rod AHR through the cladding thickness. Figure 33 showed HAZ metallographic detail for other S004 fuel rods.

The dendritic structure generally characteristic of the end cap welds in the fuel rods is shown in Figure 53. From the limited data available, the welds in the three assemblies appear very similar. This similarity is not unexpected since the welding processes and practice used in the nuclear fuel fabrication industry are closely controlled. 
TABLE 27. S004 Cladding Thickness Measurements

\begin{tabular}{|c|c|c|c|c|c|}
\hline Specimen & Neg No. & $\begin{array}{l}\text { Magnification } \\
\text { (Nominal) }\end{array}$ & $\begin{array}{l}\text { Measured } \\
\text { Thickness } \\
\left(\text { in. } \times 10^{-3}\right) \\
\end{array}$ & $\begin{array}{r}\text { Clade } \\
\text { Average } \\
\end{array}$ & $\begin{array}{l}\text { ing Thickness, } \\
\text { of Group (in.) } \\
\text { With Calibration } \\
\text { Correction } \\
\left(\begin{array}{ll}\times 1.015) \\
\end{array}\right.\end{array}$ \\
\hline $\begin{array}{l}\text { Archive } \\
\text { (Etched) }\end{array}$ & PNL & $100 x$ & $\begin{array}{l}1.67 \\
1.61 \\
1.66\end{array}$ & 0.01663 & $0.01688(a)$ \\
\hline $\begin{array}{l}\text { AHR } 56,75 \text { in. } \\
(\text { A.P. })(b)\end{array}$ & $\begin{array}{l}B C L-332 \\
B C L-333 \\
B C L-334 \\
B C L-335\end{array}$ & $\begin{array}{l}100 x \\
" 100 x \\
100 x \\
" 100 x \\
100 \\
100 x \\
10\end{array}$ & $\begin{array}{l}1.63 \\
1.64 \\
1.66 \\
1.66 \\
1.66 \\
1.66 \\
1.65 \\
1.66 \\
1.63 \\
1.62 \\
1.64\end{array}$ & $\begin{array}{r}0.01647 \\
+0.00014\end{array}$ & $0.01672(a)$ \\
\hline ABG 56.75 in. & $\begin{array}{l}\mathrm{BCL}-342 \\
\mathrm{BCL}-343 \\
\mathrm{BCL}-344 \\
\mathrm{BCL}-345\end{array}$ & $\begin{array}{l}100 x \\
" 1 \\
100 x \\
" 1 \\
" 100 x \\
" 1 \\
100 x \\
1 " \\
"\end{array}$ & $\begin{array}{l}1.63 \\
1.64 \\
1.64 \\
1.65 \\
1.65 \\
1.65 \\
1.65 \\
1.65 \\
1.65 \\
1.64 \\
1.64 \\
1.64\end{array}$ & $\begin{array}{r}0.01644 \\
+0.00007\end{array}$ & $0.01669(a)$ \\
\hline $\begin{array}{l}\operatorname{Archive(c)} \\
(\text { A.P.) }\end{array}$ & $\begin{array}{l}\text { PNL }-0^{\circ} \\
\text { (weld) } \\
\text { PNL }-90^{\circ} \\
\text { PNL }-180^{\circ} \\
\text { PNL }-270^{\circ}\end{array}$ & $\begin{array}{l}100 x \\
" 1 \\
100 x \\
" \\
" \\
100 x \\
" \\
" \\
100 x \\
"\end{array}$ & $\begin{array}{l}1.66 \\
1.66 \\
1.66 \\
1.68 \\
1.68 \\
1.68 \\
1.68 \\
1.68 \\
1.68 \\
1.65 \\
1.66 \\
1.65\end{array}$ & $\begin{array}{r}0.01668 \\
+0.00013\end{array}$ & $0.01675(d)$ \\
\hline
\end{tabular}

(a) Calibration correction factor was 1.015

(b) A.P. = as polished

(c) Specimen reworked on February 17, 1981.

(d) Calibration correction factor was 1.004 . 
HC50814 WELD AREA

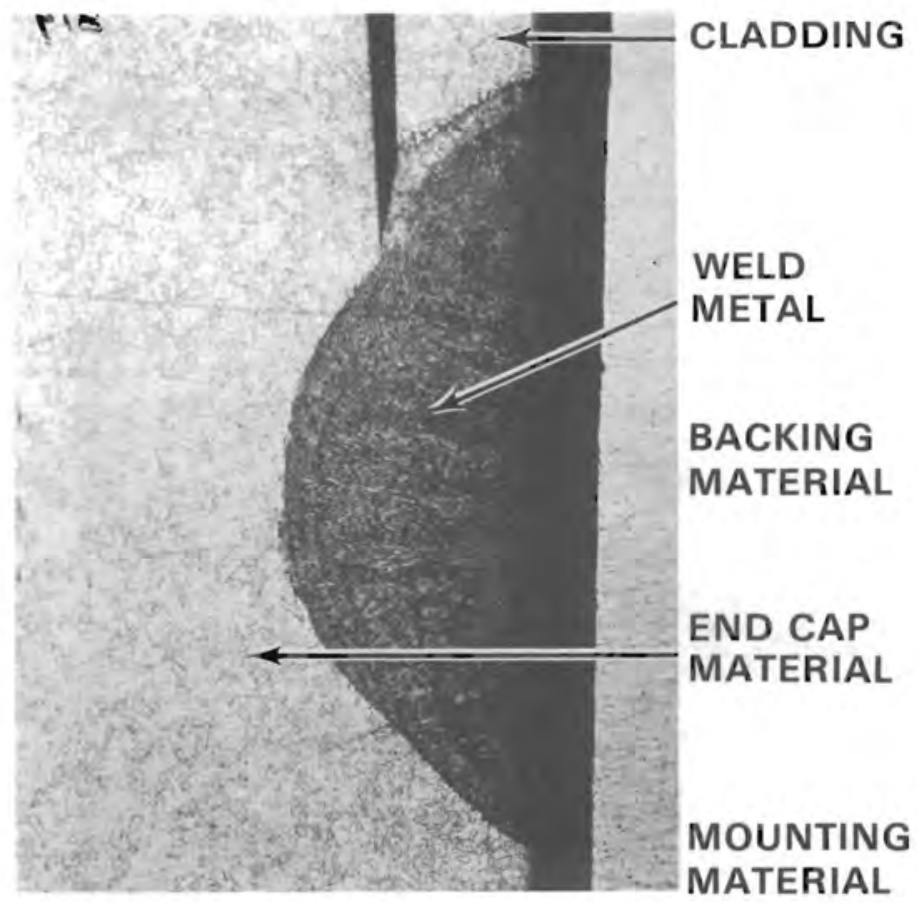

(a)

HC50818 BASE METAL

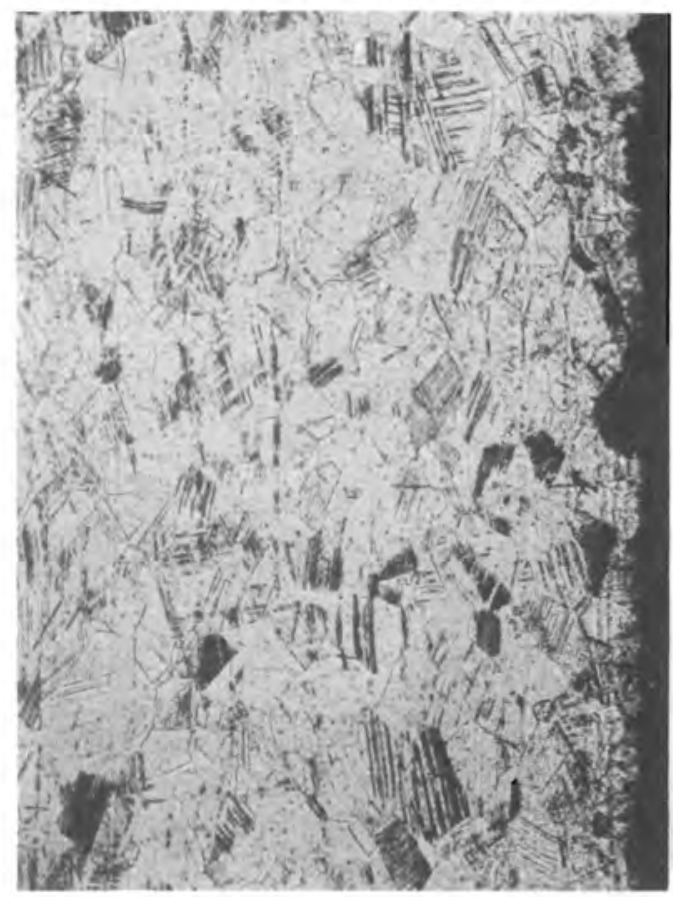

HC50803 WELD AREA

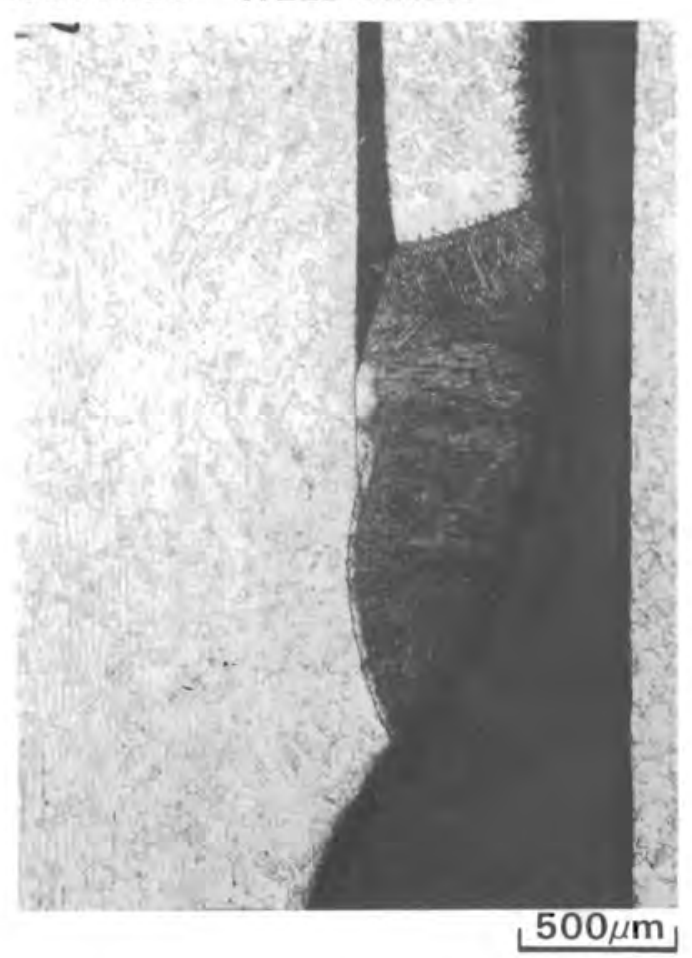

(b)

\section{HC50806 BASE METAL}

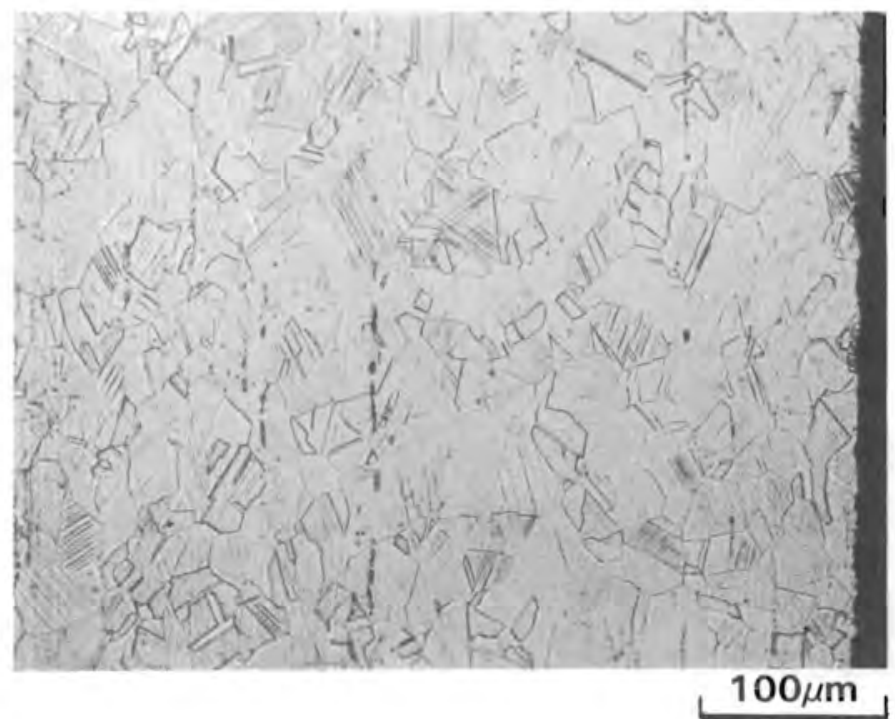

FIGURE 52. Metallography of Weld Area and Base Metal Near Lower End Cap Weld Areas of Fuel Rods (a) AHR from Assembly S004 and (b) 217E02 from Assembly H07 

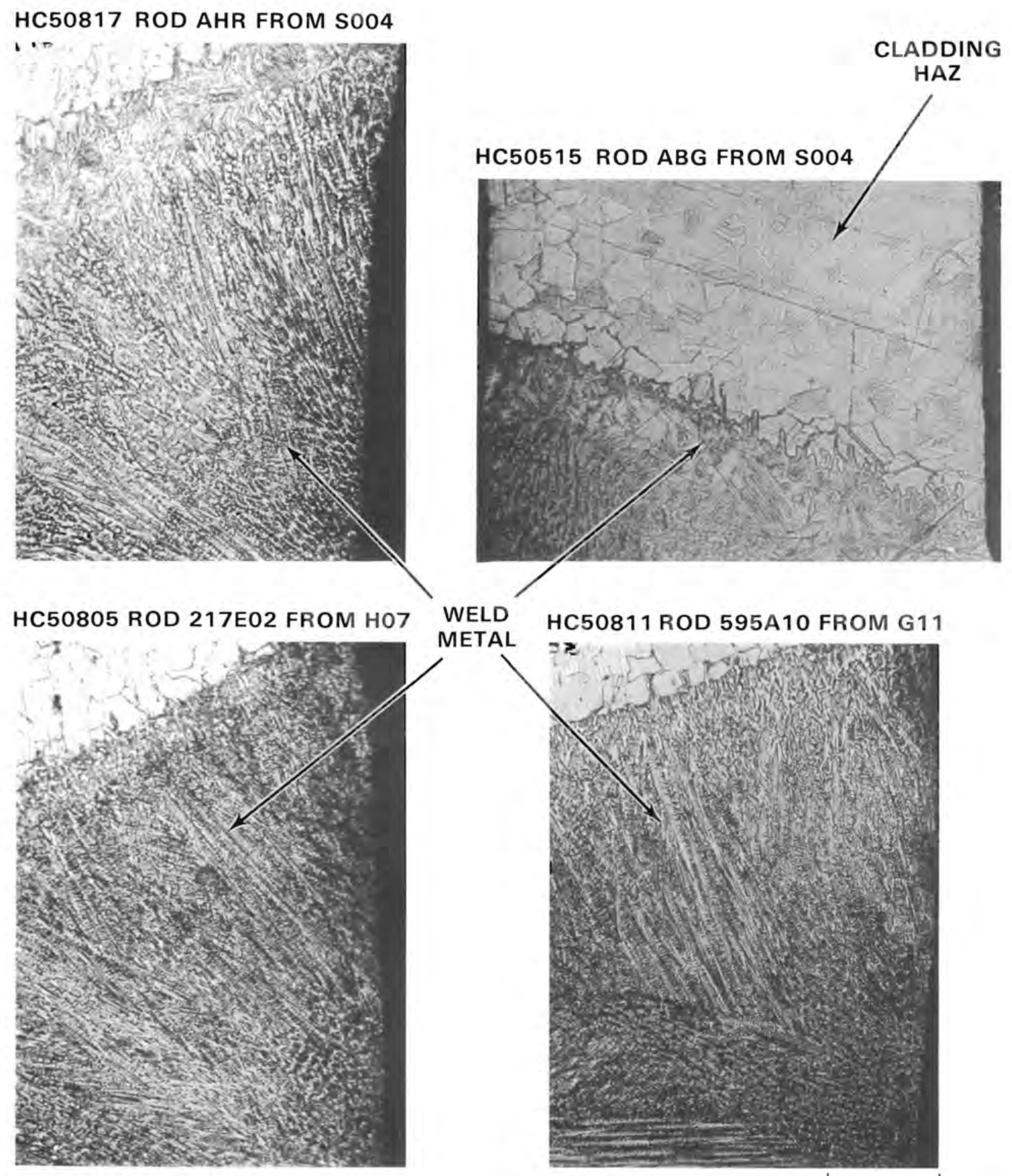

HC50811 ROD 595A10 FROM G11

METAL $\rightarrow$

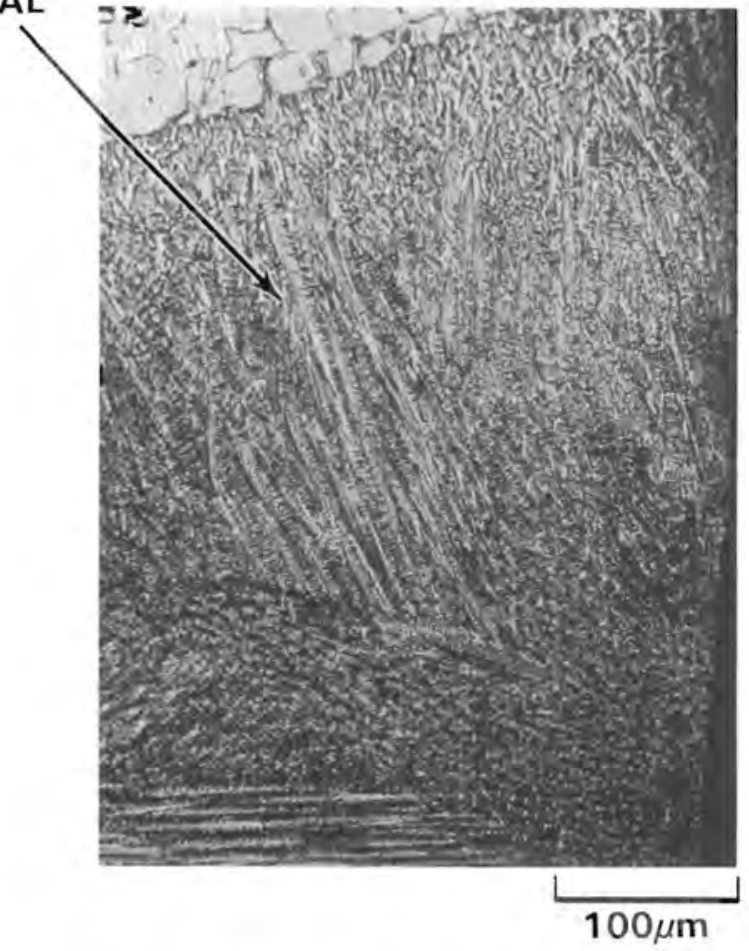

FIGURE 53. Metallography of Weld Metal from End Cap Welds from Connecticut Yankee Fue 1 Rods ( $H A Z$ = heat-affected zone) 
Cladding ovality was evident in the macrographs shown in Figures 54 through 60, especially in the sections at $56.75 \mathrm{in.}(144 \mathrm{~cm})$ above the bottom of the rod in both $A B G$ and AHR. The fuel-cladding gap was larger in rod $A B G$ than in AHR. The fuel-cladding gap was very small in the Gll rod and essentially nil in the $\mathrm{HOT}$ rods.

Fuel rods from both $\mathrm{SOO4}$ and G11 showed some cases of fuel chips adhering to the cladding ID. No adherent fuel chips were observed in the HO7 rods.

Circumferential fuel cracking was observed in fuel rods from the HO7 assembly. Circumferential cracks were less pronounced and fewer in rods from the Gll assembly, and none were observed in rods from the S004 assembly. The circumferential cracking occurred only in high-power regions of the fuel rod. Ceramography

Ceramographic specimens were examined to document fuel pellet cracking and chipping and such fuel microstructural features as porosity, grain size, and metallic fission product inclusion formation. (a) Specimen preparation was identical to that for metallography specimens through the polishing operation. Ceramography specimens were examined in both as-polished and etched conditions. The etchant used for examination of fuel microstructure consisted of 85 parts $\mathrm{H}_{2} \mathrm{O}_{2}$ and 15 parts concentrated $\mathrm{H}_{2} \mathrm{SO}_{4}$. The macrographs of the as-polished fuel clearly show pellet cracking (Figures 55 through 60). Radial cracks are the most pronounced, but there is not circumferential cracking comparable to that seen in the high-power regions of the fuel rods from assemblies Gll and H07. Figures 38 through 40 showed that there were pellet chips in S004 fuel rods. However, no fuel pellet chips were found lodged in the fuel-cladding gap. Pellet chips were found lodged in the fuel-cladding gap in the Gll and H07 fuel

(a) The term "metallic fission product inclusions" is typically used with light-water reactor fuels (Garzarolli and Manzel 1979). The term "metallic fission product ingots" is typically used with fast reactor fuels (Zhou and 01 ander 1981). 


\section{HC50326}

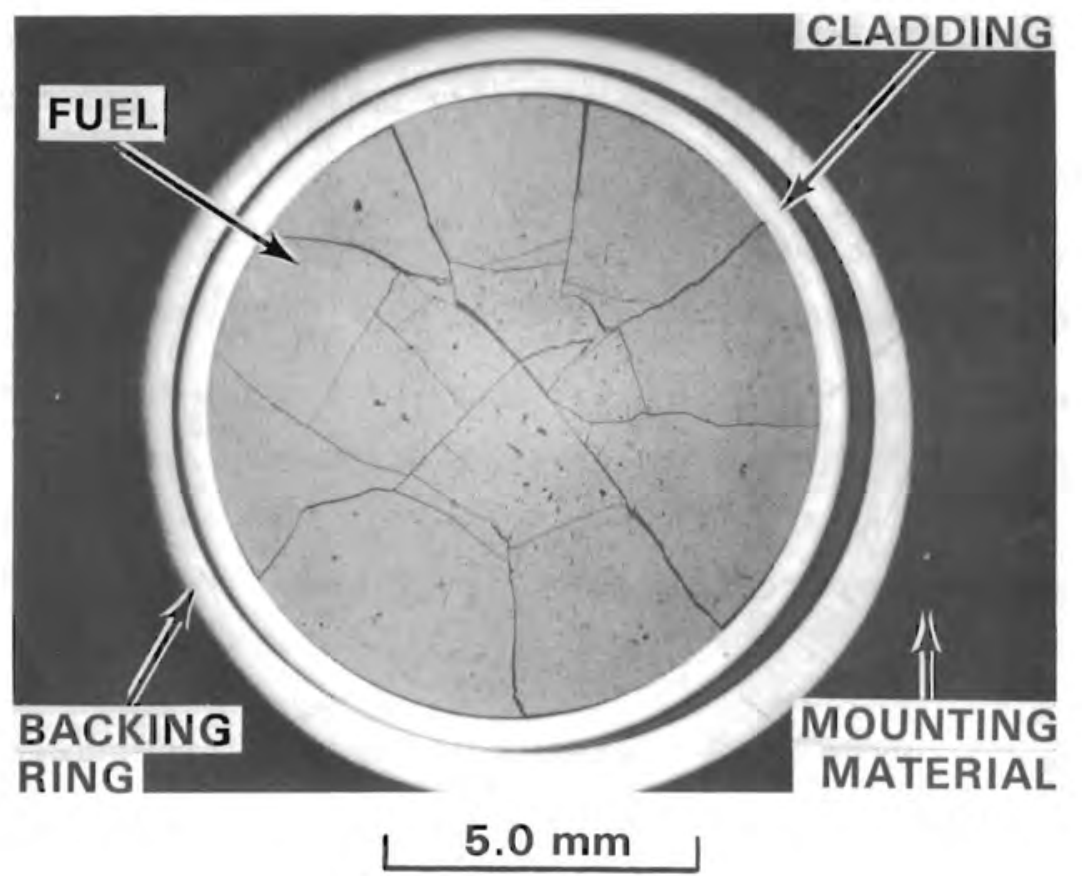

FIGURE 54. As-Polished Macrograph of Rod AHR at $36.50 \mathrm{in.}(93 \mathrm{~cm})$ from Bottom End

\section{HC50331}

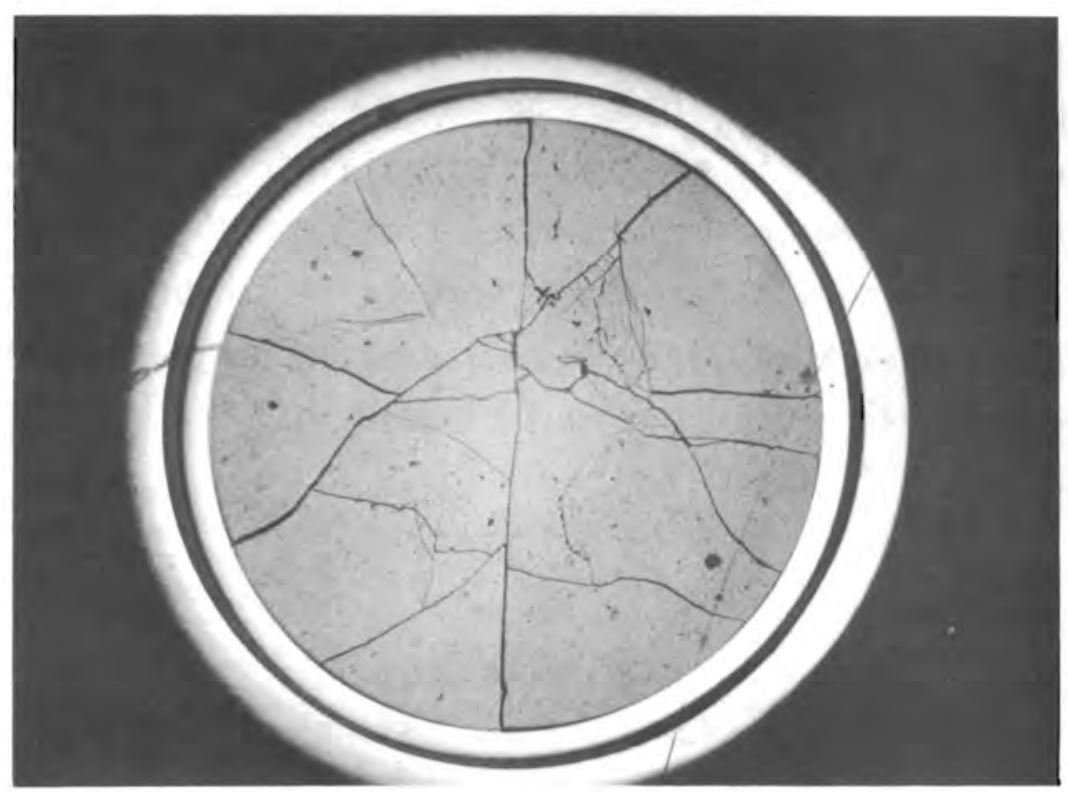

\section{$5.0 \mathrm{~mm}$}

FIGURE 55. As-Polished Macrograph of Rod AHR at $56.75 \mathrm{in.}(144 \mathrm{~cm})$ from Bottom End 


\section{HC50336}

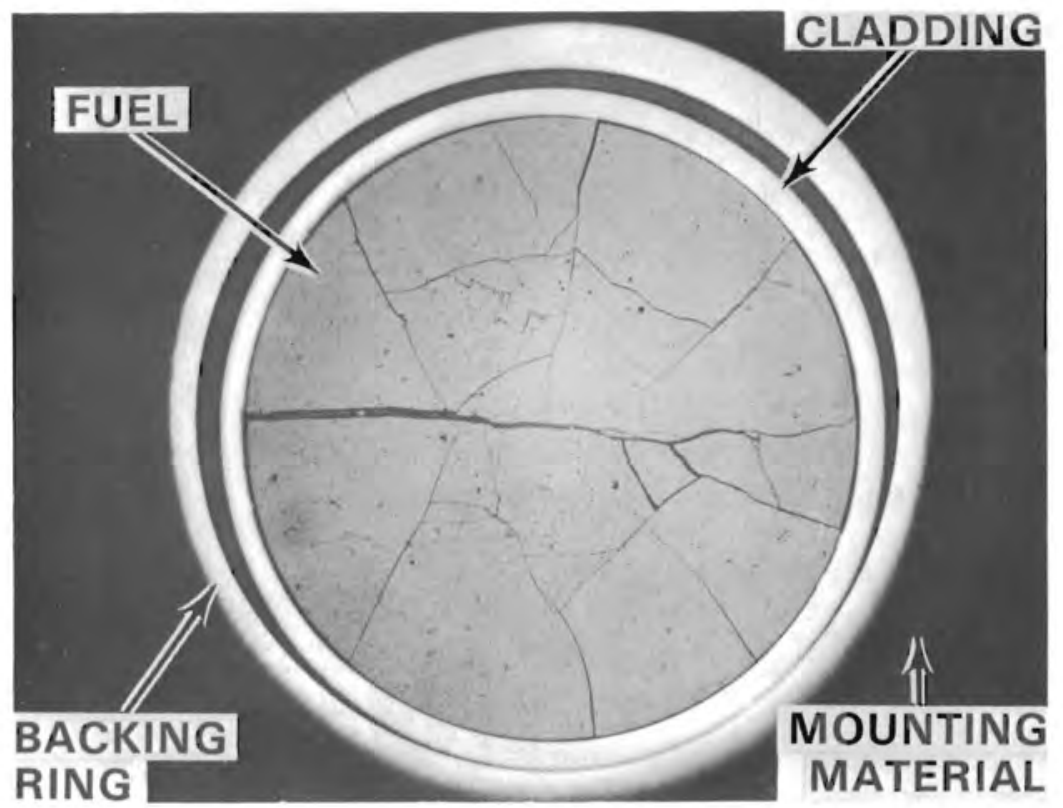

\section{$5.0 \mathrm{~mm}$}

FIGURE 56. As-Polished Macrograph of Rod AHR at $80.50 \mathrm{in.}(204 \mathrm{~cm})$ from Bottom End

\section{HC50346}

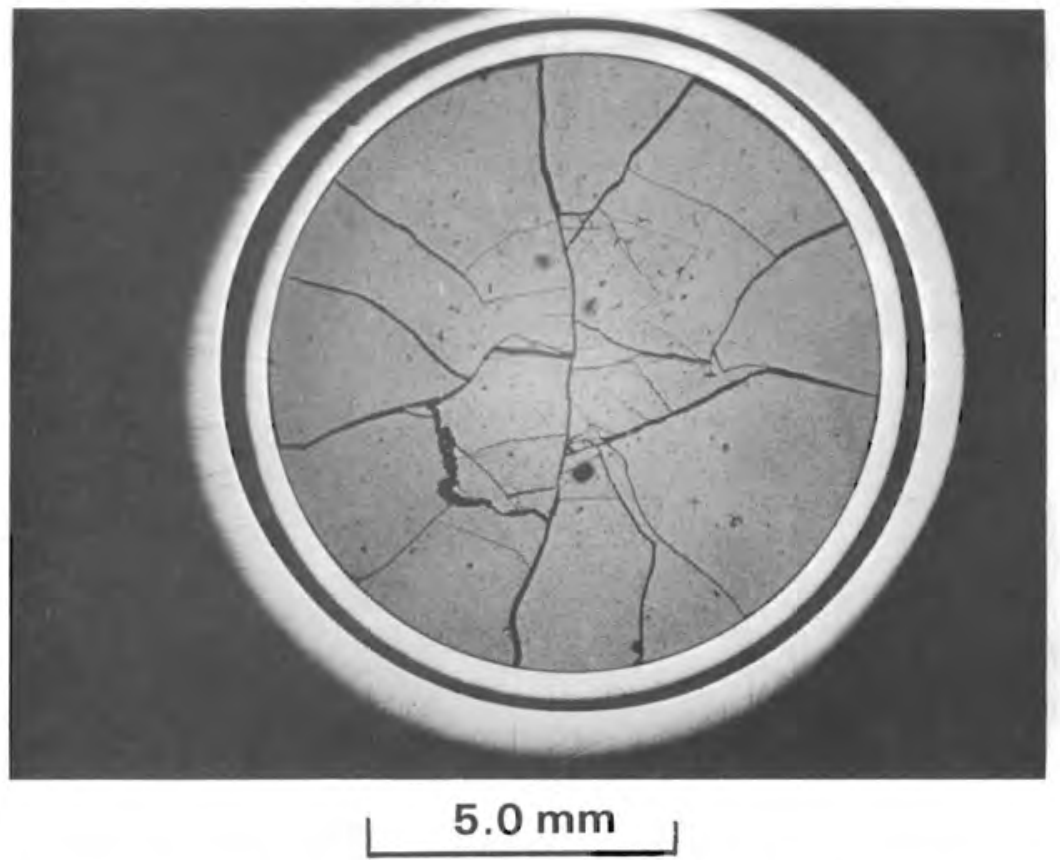

FIGURE 57. As-Polished Macrograph of Rod AHR at $83.75 \mathrm{in.}(213 \mathrm{~cm})$ from Bottom End 
HC50351

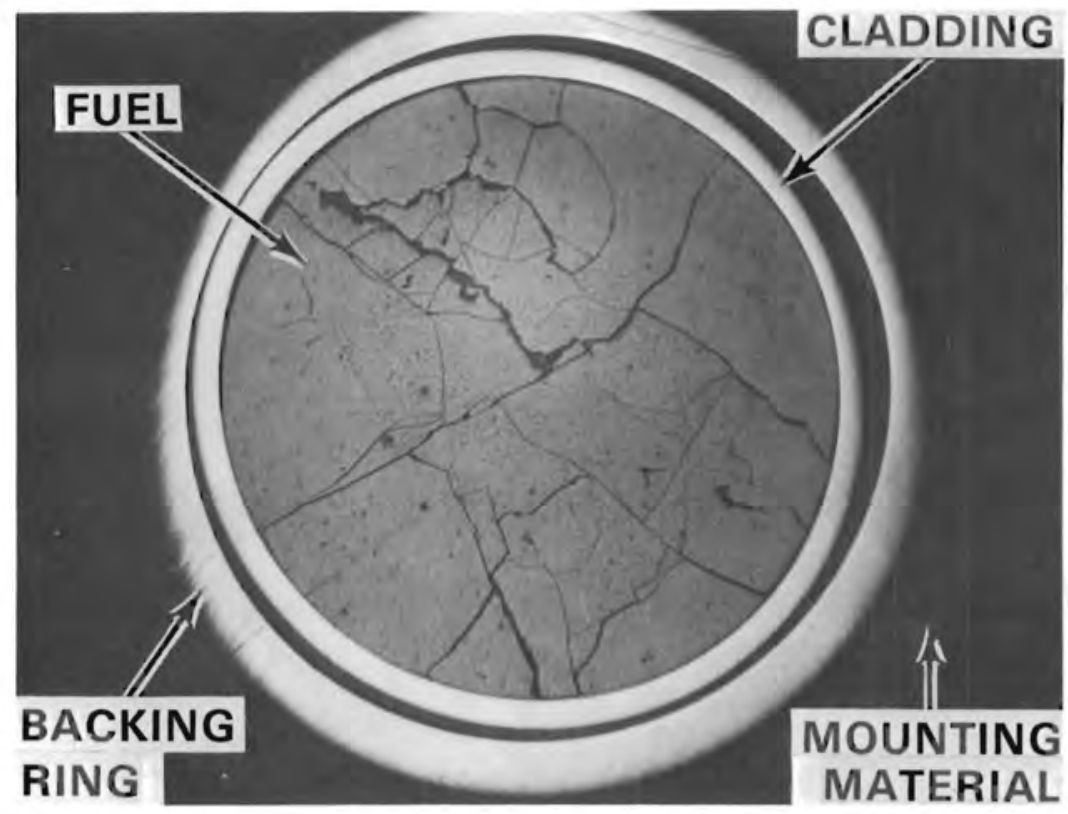

$5.0 \mathrm{~mm}$

FIGURE 58. As-Polished Macrograph of Rod AHR at $98.25 \mathrm{in.}(250 \mathrm{~cm})$ from Bottom End

\section{HC50356}

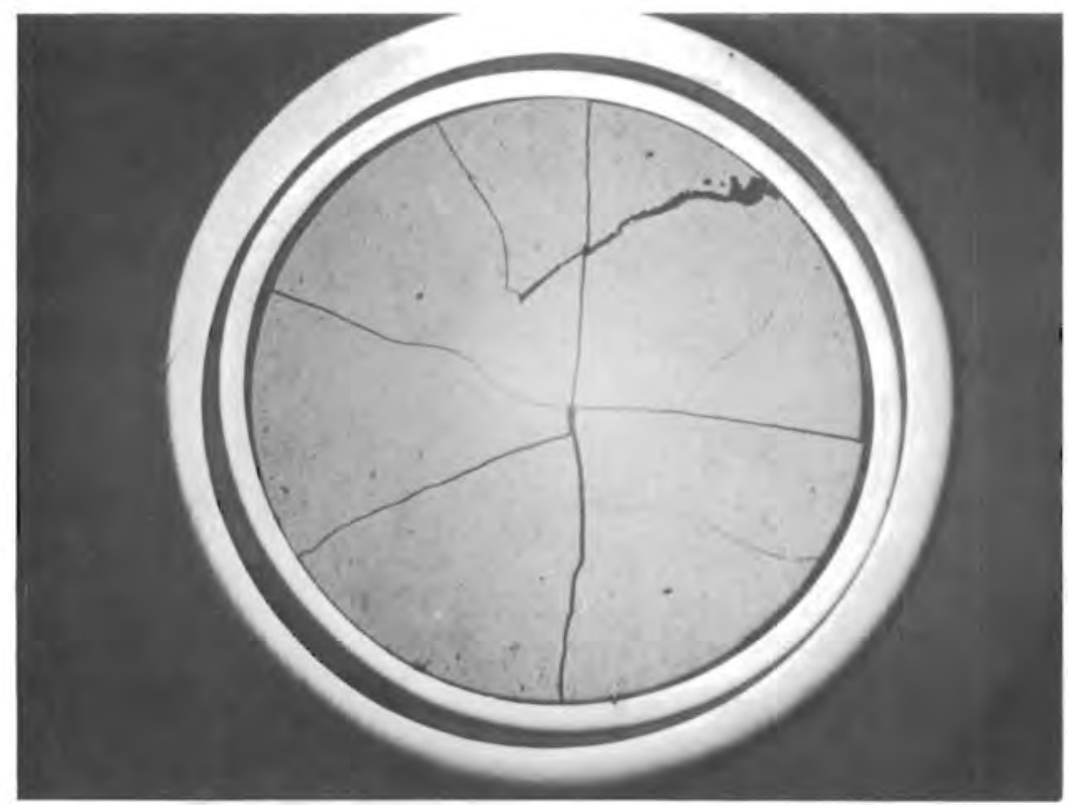

\section{$5.0 \mathrm{~mm}$}

FIGURE 59. As-Polished Macrograph of Rod ABG at $41.50 \mathrm{in.}(105 \mathrm{~cm})$ from Bottom End 


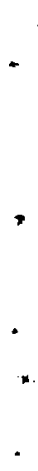




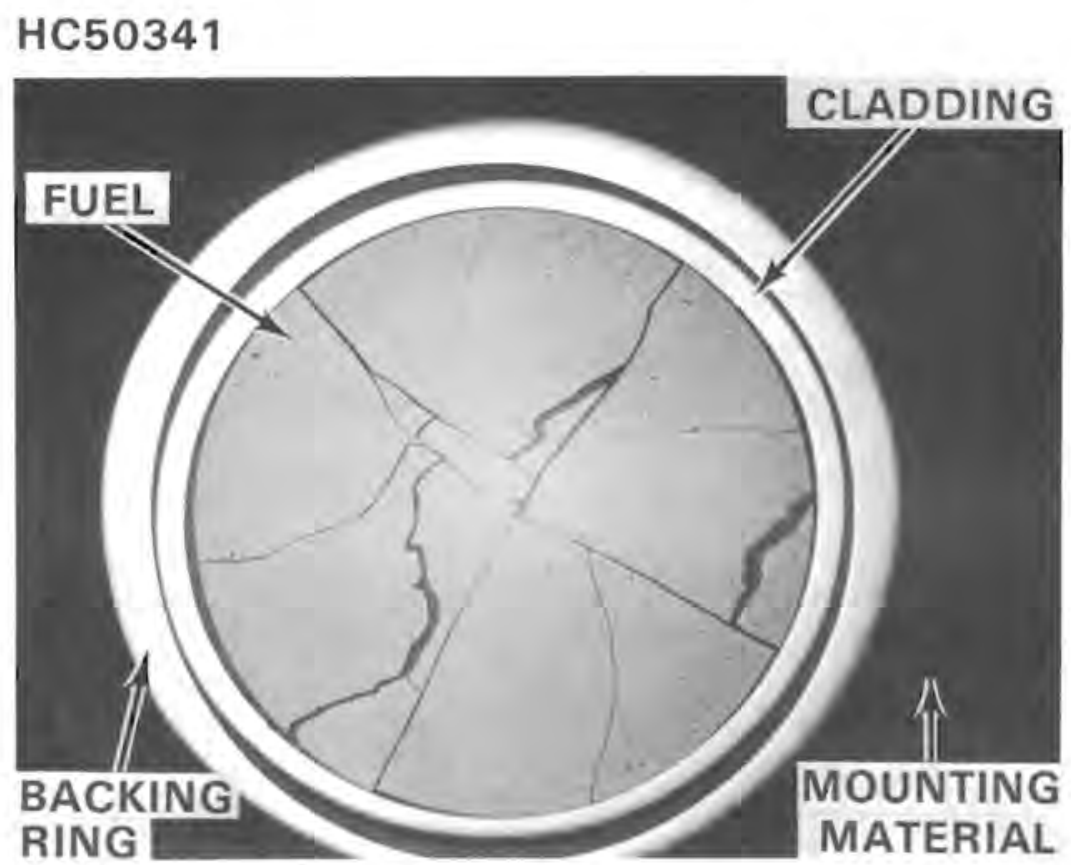

$5.0 \mathrm{~mm}$

FIGURE 60. As-Polished Macrograph of Rod ABG at 56.75 in. $(144 \mathrm{~cm})$ from Bottom End

rods, and were consistently associated with cladding cracks that developed in the reactor, probably due to high local stresses at the chips. (a)

The reader should be cautious about forming opinions regarding fuel porosity from the ceramography. A significant number of sma11 fuel particles can inadvertantly be pulled out of the pellet surface during specimen preparation.

The etched fue 1 specimens showed a minimal increase in grain size in rod ABG (Figure 61) and a small increase in grain size in rod AHR (Figure 62). Figure 63 is a macrograph of a transverse section of AHR located $56.75 \mathrm{in}$. $(144 \mathrm{~cm})$ above the bottom of the rod. The fuel areas shown enlarged in Figure 64 are summarized in Figure 63. One feature noted in rod AHR in Figure 63 is that the grain size gradient in areas $\# 1$ and $\# 4$ is perpendicular to the fue 1

(a) The pellet chips in the S004 rods were much smaller than the chips in H07 and G11 rods. The pellet chips in $\mathrm{HOT}$ and G11 rods were generated during the fabrication process. The nominal diametral gap (i.e., cladding ID minus pellet diameter) for S004, G11, and $\mathrm{HO}$ fuel rods was $0.14 \mathrm{~mm}$ (0.0055 in.). S004 fuel densified about the same amount as G11 fuel but swelled at a lower rate. 
$+$

$\checkmark$ 
FUEL

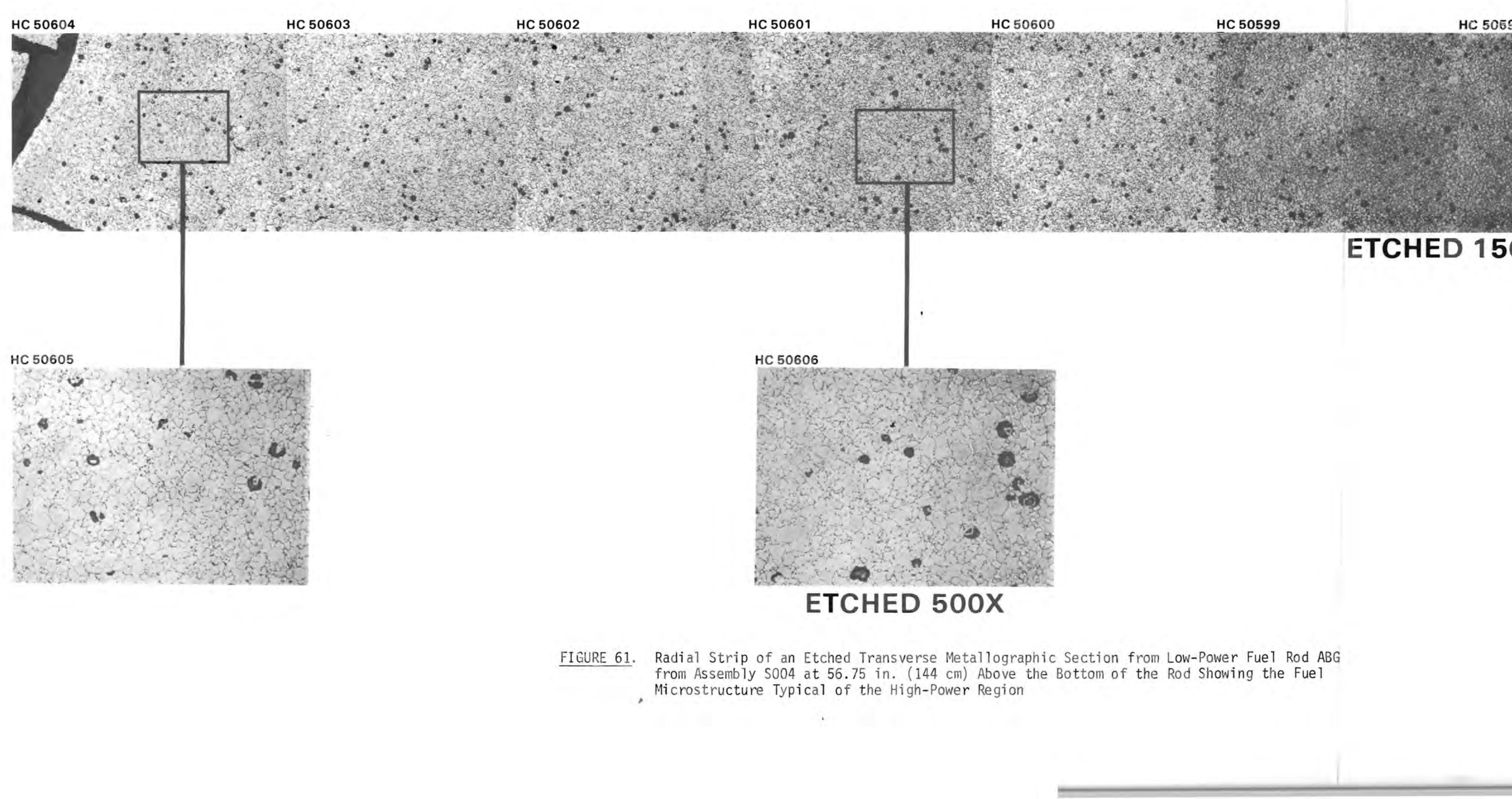




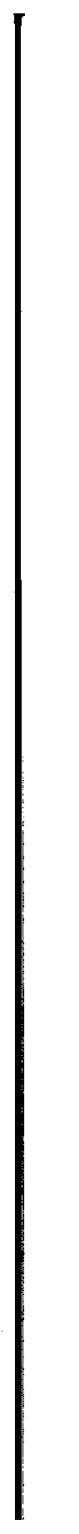

$\checkmark$

. 


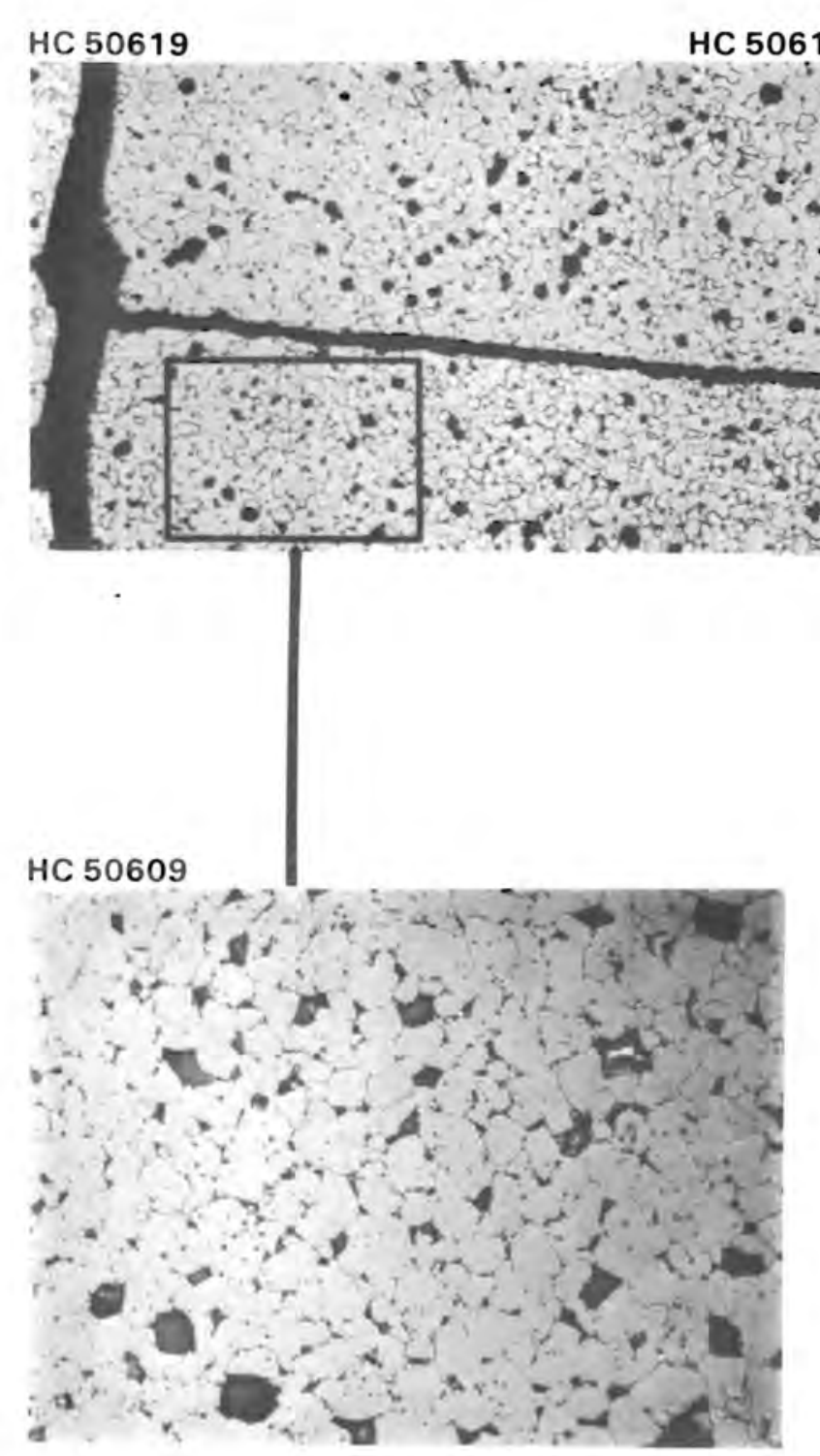

HC 50616

HC 50615

HC 50614

HC 50617
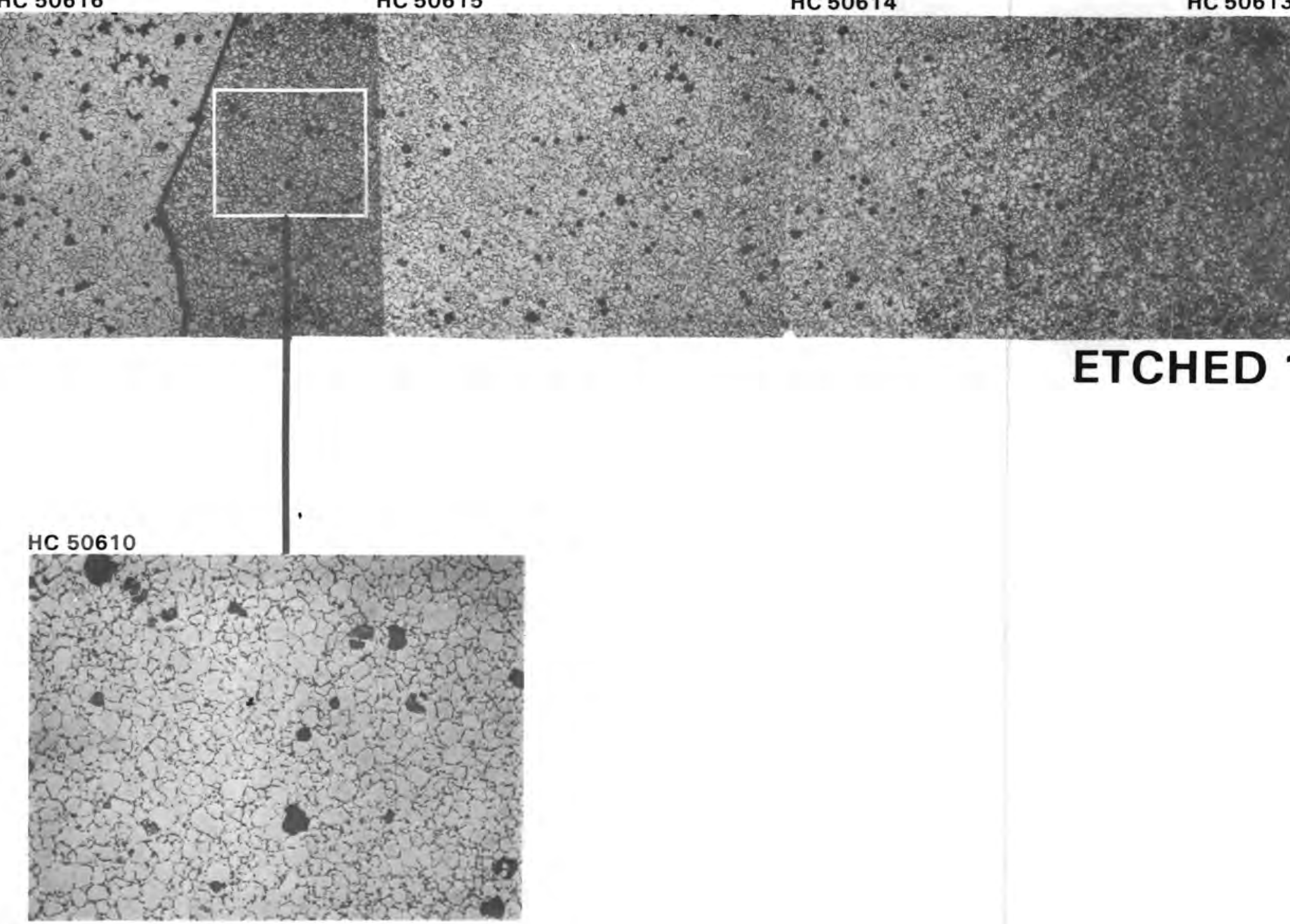

ETCHED 500X

FIGURE 62. Radial Strip of Radial Strip of an Etched Transverse Metallographic Section from Rod Showing the Fuel from Assembly SO04 at 56.75 in. $(144 \mathrm{~cm})$ Above
Microstructure Typical of the High-Power Region 


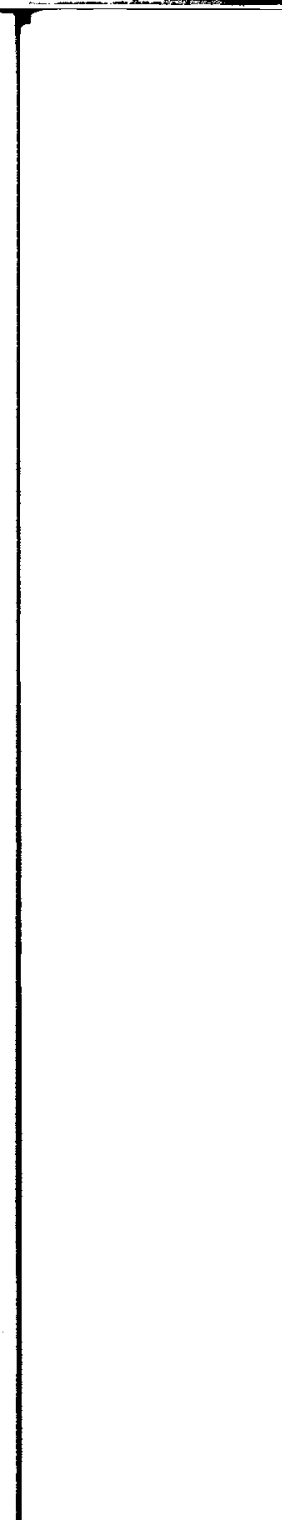

$\checkmark$

- 


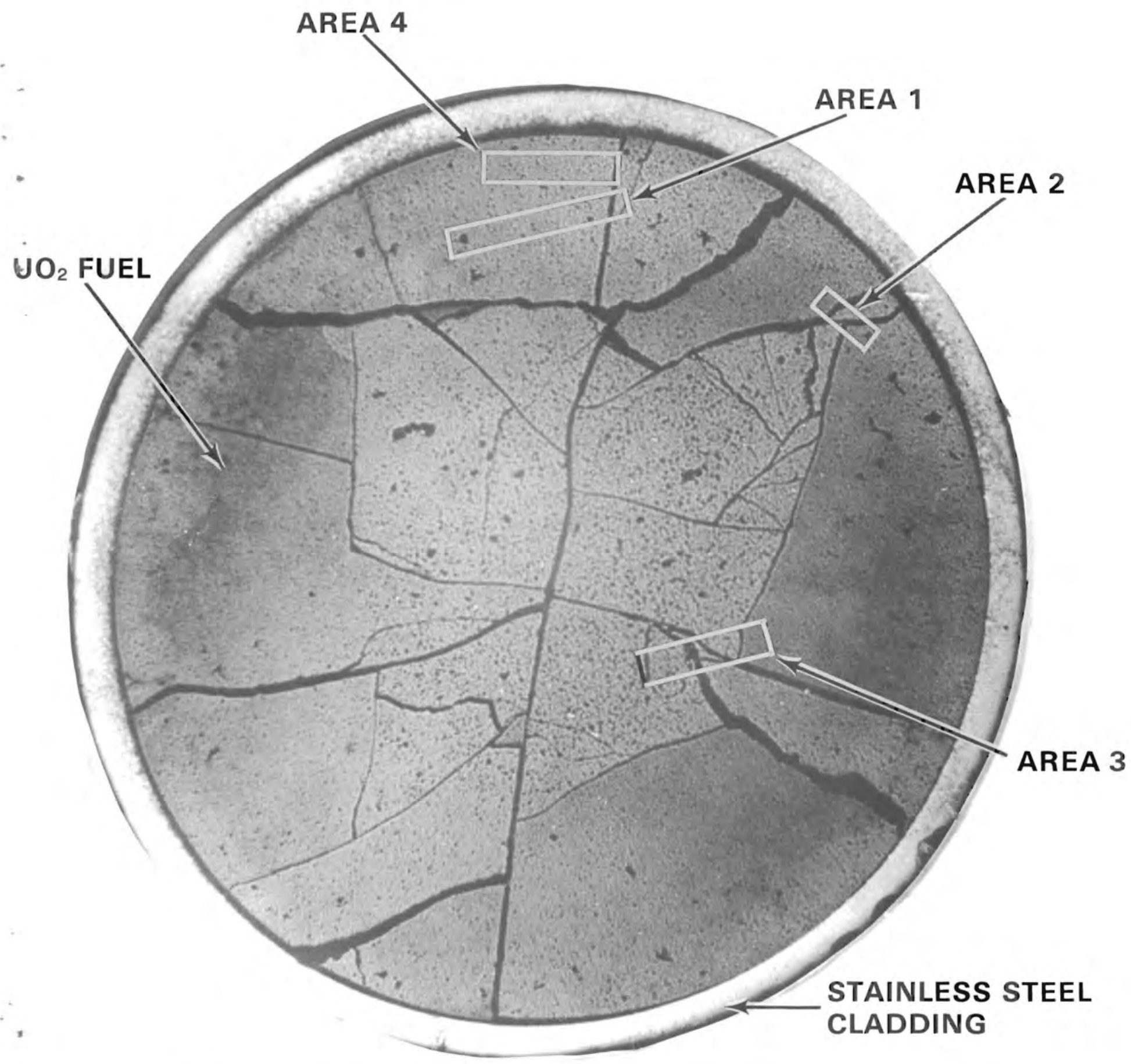

FIGURE 63. Macrograph of an Etched Transverse Metallographic Section from Rod AHR from Assembly S004 at $56.75 \mathrm{in.}(144 \mathrm{~cm})$ Above the Bottom of the Rod Showing the Locations of Photo Composite Strips of the Fuel (see Figure 64) 

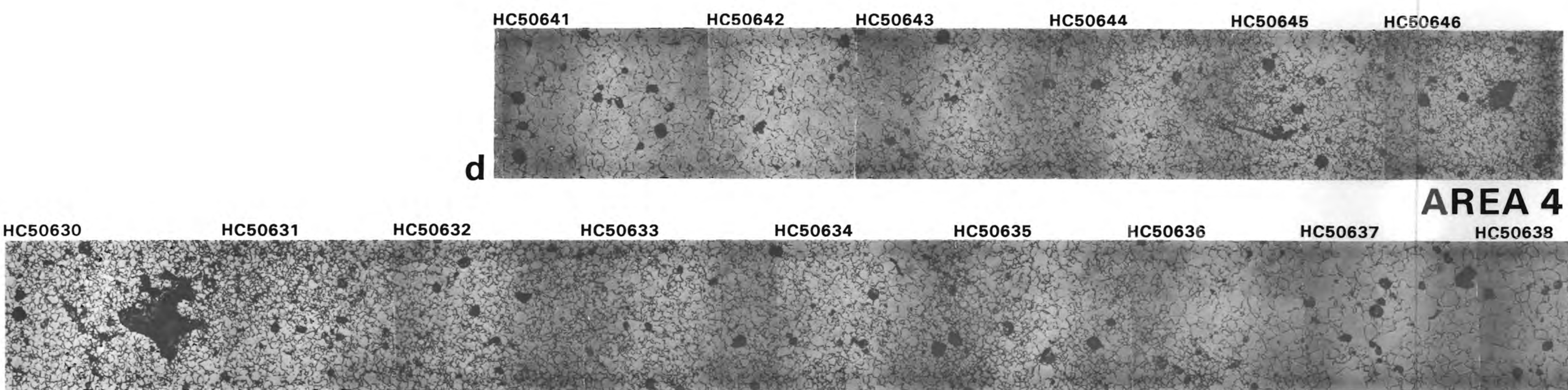

a

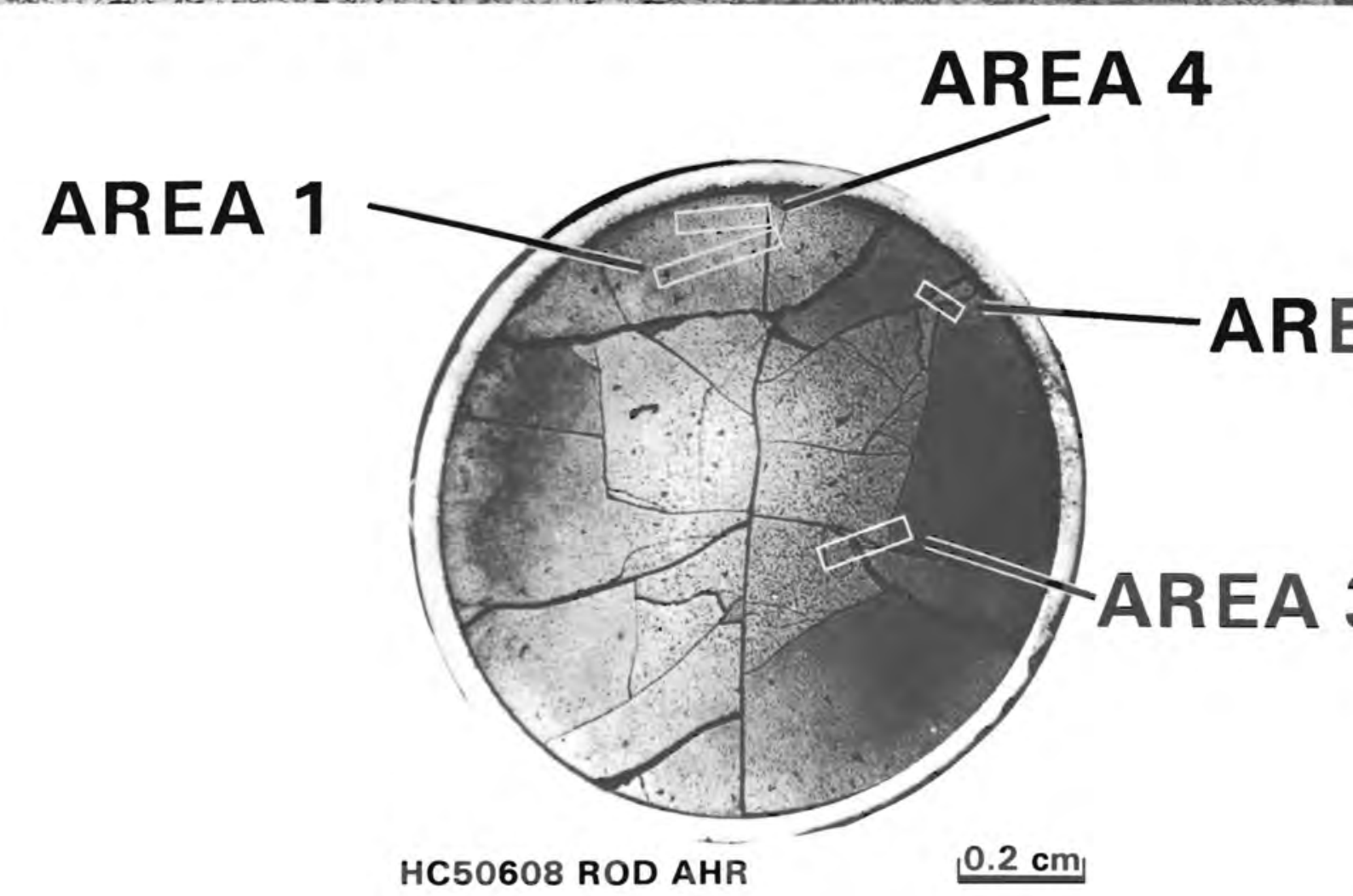

AREA 4 HC50638

HC50636

HC50637

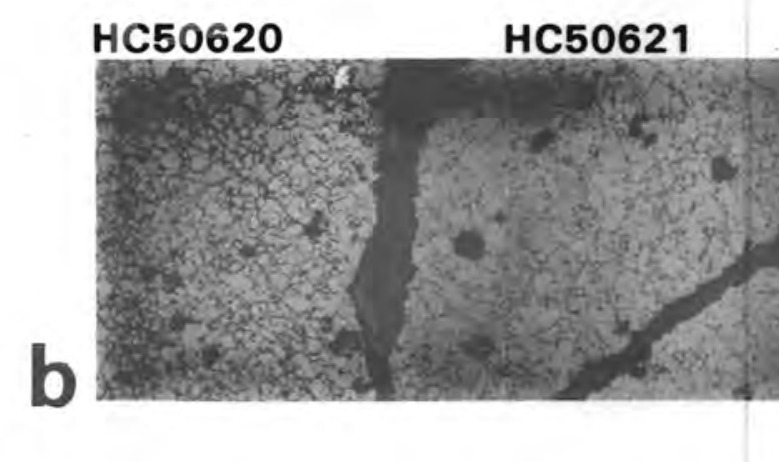

ETCHE HC50622

FIGURE 64. Photo Composite of (a) Area \#1, (b) Area \#2, (c) Area \#3, (d) Area \#4 from Figure 63 Showing Details of the Fuel Microstructure. Etched transverse metallographic section from SOO4 Rod AHR at 56.75 in $(144 \mathrm{~cm})$ above the bottom of the rod. 

radius and that the change in grain size is discontinuous across a crack interface, as shown in Figure 65 and area \#3 of Figure 64c. (a) Figure 66 illustrates the range of grain sizes observed in rods $A B G$ and $A H R$.

Metallic fission product inclusions (i.e., the small bright spots seen in the center of the AHR fuel in Figure 66) are not observed in rod ABG. Higher operational fuel temperatures are indicated in fuels with metallic fission product inclusions than in similar fuels without visible inclusions.

Autoradiography

The purpose of alpha and beta-gamma autoradiography is to show the relative distributions of alpha and beta-gamma emitting nuclides in an irradiated fuel specimen. The principal alpha emitters are plutonium and the transuranics, e.g., Np, Am, and Cm. The beta and gamma emitters are uranium and the fission products.

\section{HC50616}

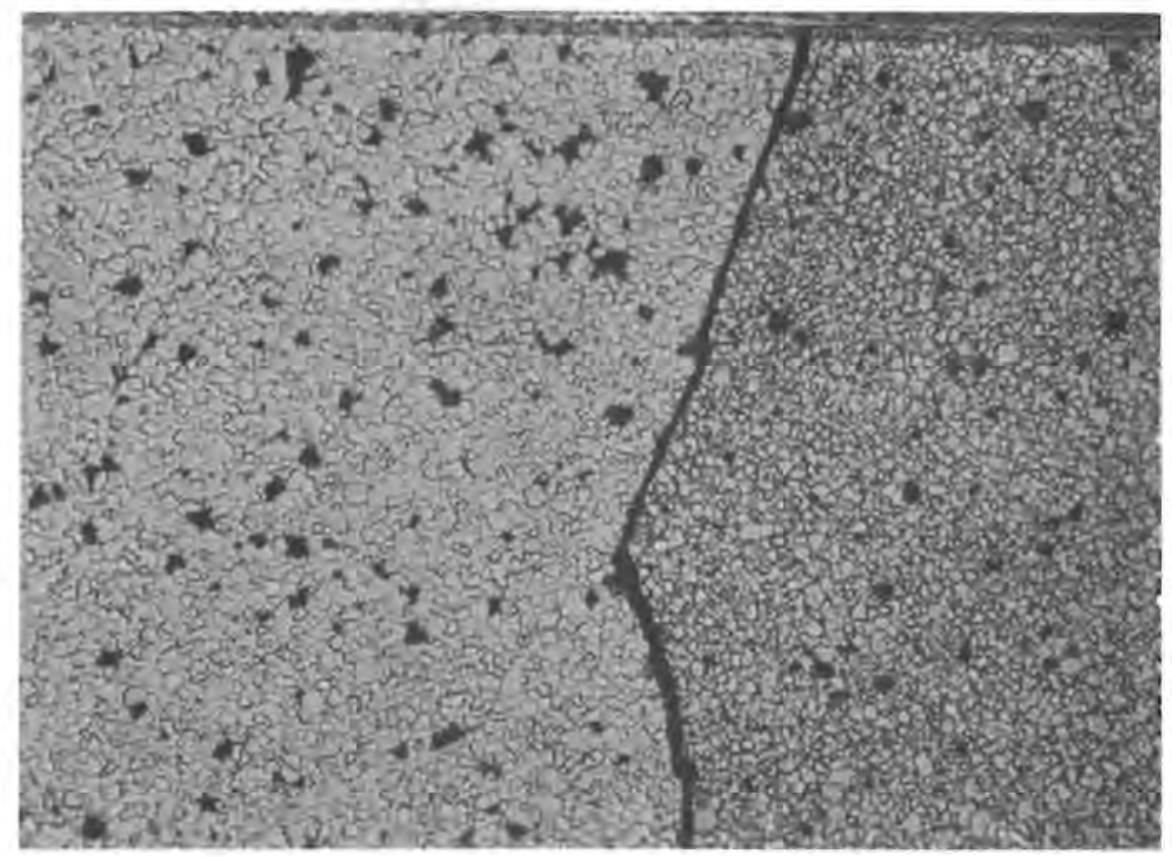

\section{$100 \mu \mathrm{m}$}

FIGURE 65. Photomicrograph Showing Grain Size Discontinuity Across a Crack Interface from the Area \#3 Location in Rod AHR (see Figure 64)

(a) The grain size increase is most likely caused by the temperature increase across the interface $(s)$. This effect is quite common. 
ABG

\section{HC 50605}

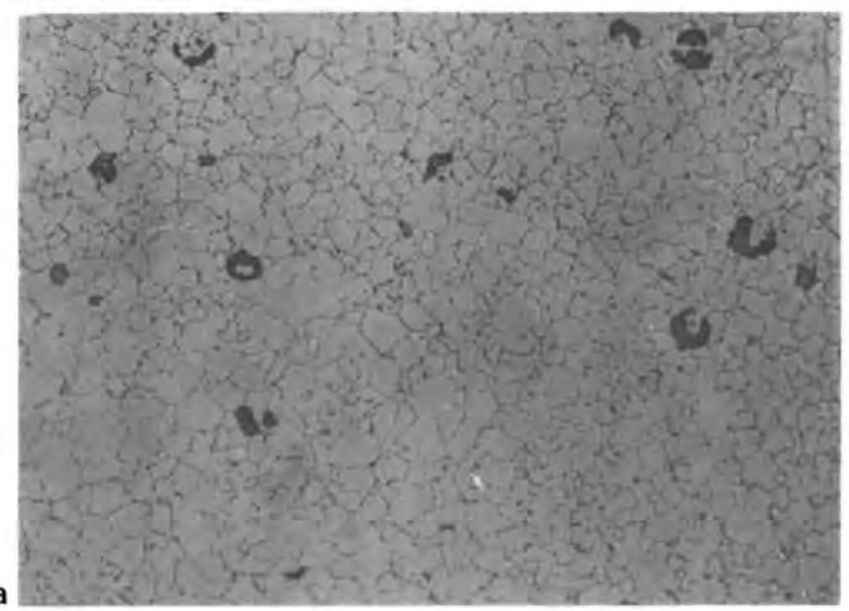

\section{HC 50609}

占

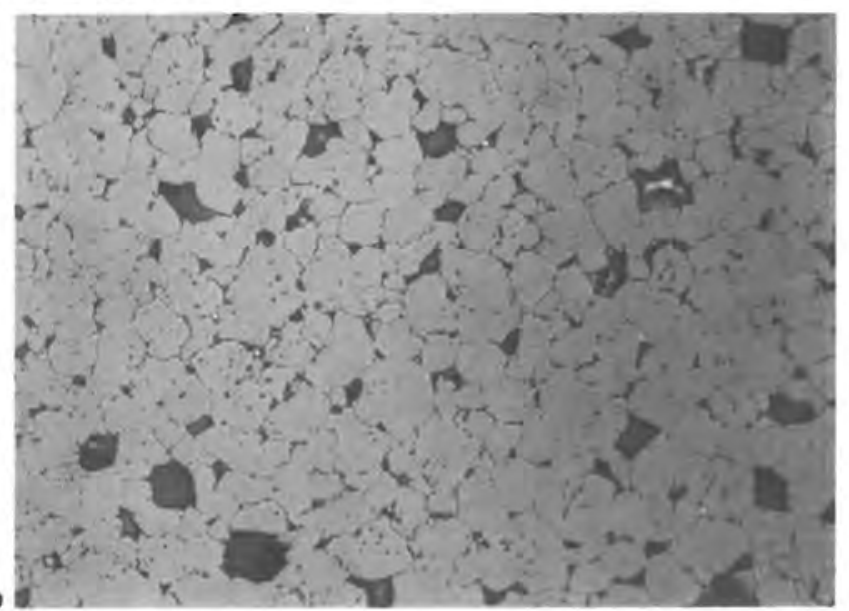

\section{HC 50607}

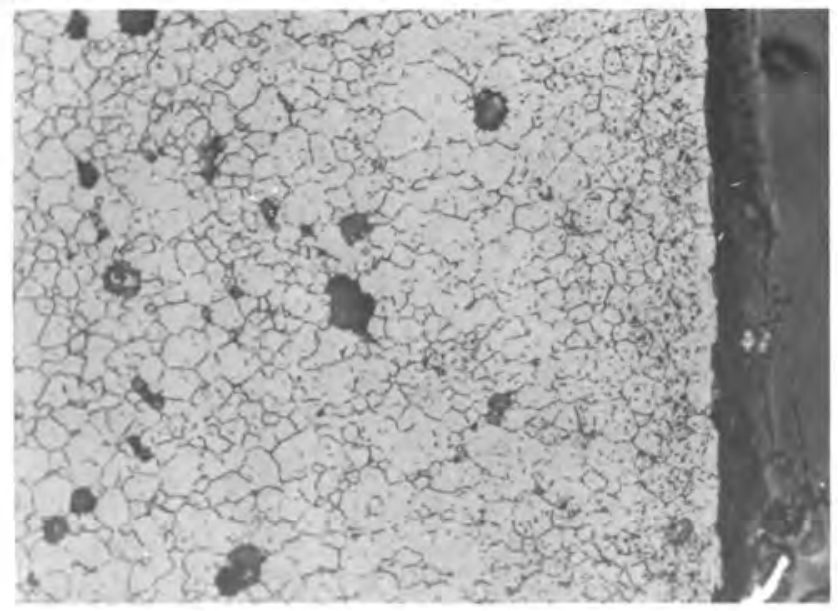

\section{HC 50611}

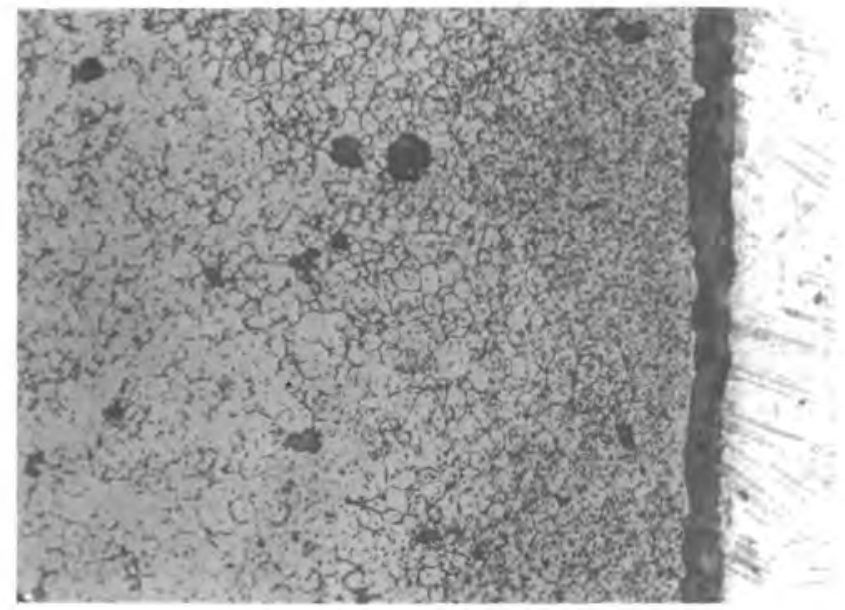

\section{AHR}

FIGURE 66. Photomicrograph of Etched Fuel Showing Range of Grain Sizes Between (a) Rod $A B G$ and (b) Rod AHR 
An autoradiograph is made by exposing film to the specimen radiation, the film being held flat against the specimen surface. The specimen surface prepared for metallogaphic examination is in the as-polished condition. Specimen No. 9 from rod AHR was placed topside down on the film to obtain the exposure.

Alpha autoradiography uses a special cellulose nitrate film. After exposure, the alpha tracks in the film are brought out by etching in a $6 \underline{\mathrm{N} \mathrm{NaOH}}$ solution. Enlargements are obtained by standard photographic techniques. Beta-gamma autoradiography uses high resolution photographic plates. The plate is developed and reversed by contact printing. Enlargements are obtained by standard photographic techniques. A light gray color on the auto-radiograph indicates emitters; black indicates that no emitters were detected.

The alpha autoradiograph (Figure 67) shows an increase in alpha emitter concentration over a very small distance around the periphery of the fuels; the cladding appears to be free of alpha emitters. The beta-gamma autoradiograph (Figure 68) also shows a steep increase in emitter concentration around the fuel periphery, along cracks, and at some voids. A comparison of the optical macrograph in Figure 69 with the autoradiograph shows coincidence between cracks and some pores in the fuel. A radiation shine effect occurs in such void areas, thereby enhancing the images of those areas on the autoradiograph.

\section{Cladding Mechanical Properties Testing}

Cladding mechanical properties were measured to determine mechanical deformation behavior (ring crush tests), as well as strength and ductility (tensile tests). Tests to characterize cladding mechanical behavior were conducted because of the mechanical stresses that can develop during handling and transport of the spent fuel assembly. The tests focused on the cladding because it constitutes the first barrier for containment of actinides, nuclides, and fission products. 


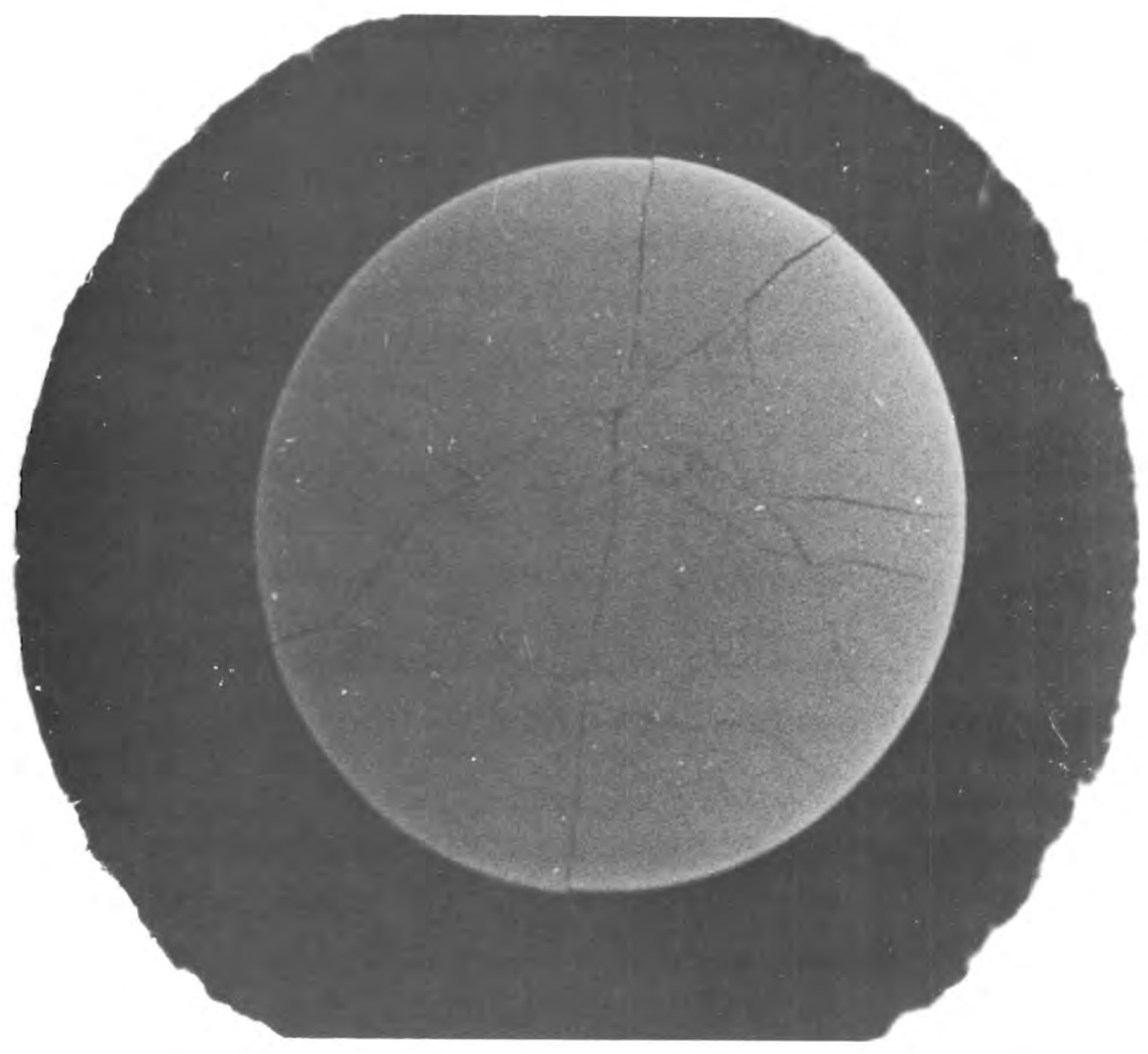

FIGURE 67. Alpha Autoradiograph from Rod AHR at $56.75 \mathrm{in.}(144 \mathrm{~cm}$ ) Above the Bottom of the Rod Showing the Increase of Alpha Emitter Concentration Over a Very Short Distance at the Fuel Periphery

The fabrication welding process can generate localized residual stresses and can degrade local mechanical and corrosion properties. Neutron irradiation affects the defect structure of the metal microstructure which, in turn, affects both mechanical and corrosion properties. Thermal environments during reactor operation can also affect metal microstructure and properties through creep processes. The fuel rod also contains fission products that provide a potentially corrosive and embrittling internal atmosphere for the cladding. 


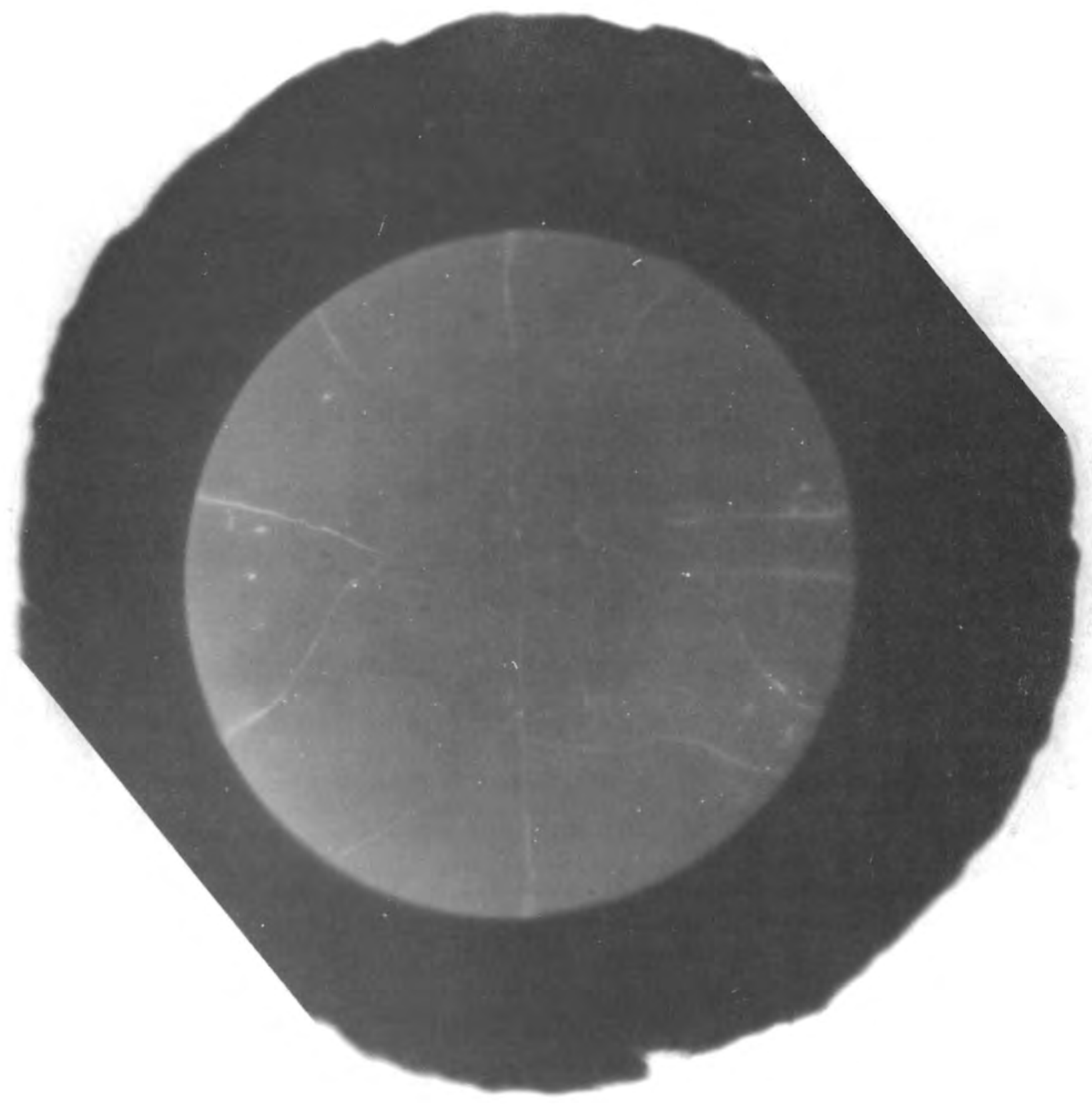

FIGURE 68. Beta-Gamma Autoradiograph from Rod AHR at 56.75 in. $(144 \mathrm{~cm})$ Above the Bottom of the Rod Showing a Steep Increase in Beta-Gamma Emitter Concentration at the Fuel Periphery, Along Cracks and at Some Voids

The external environment of the assembly is another factor. The coolant in an operating PWR is potentially more aggressive than the pool environment as a result of higher temperatures and more intense radiation. Crud deposits 


\section{A916-1}

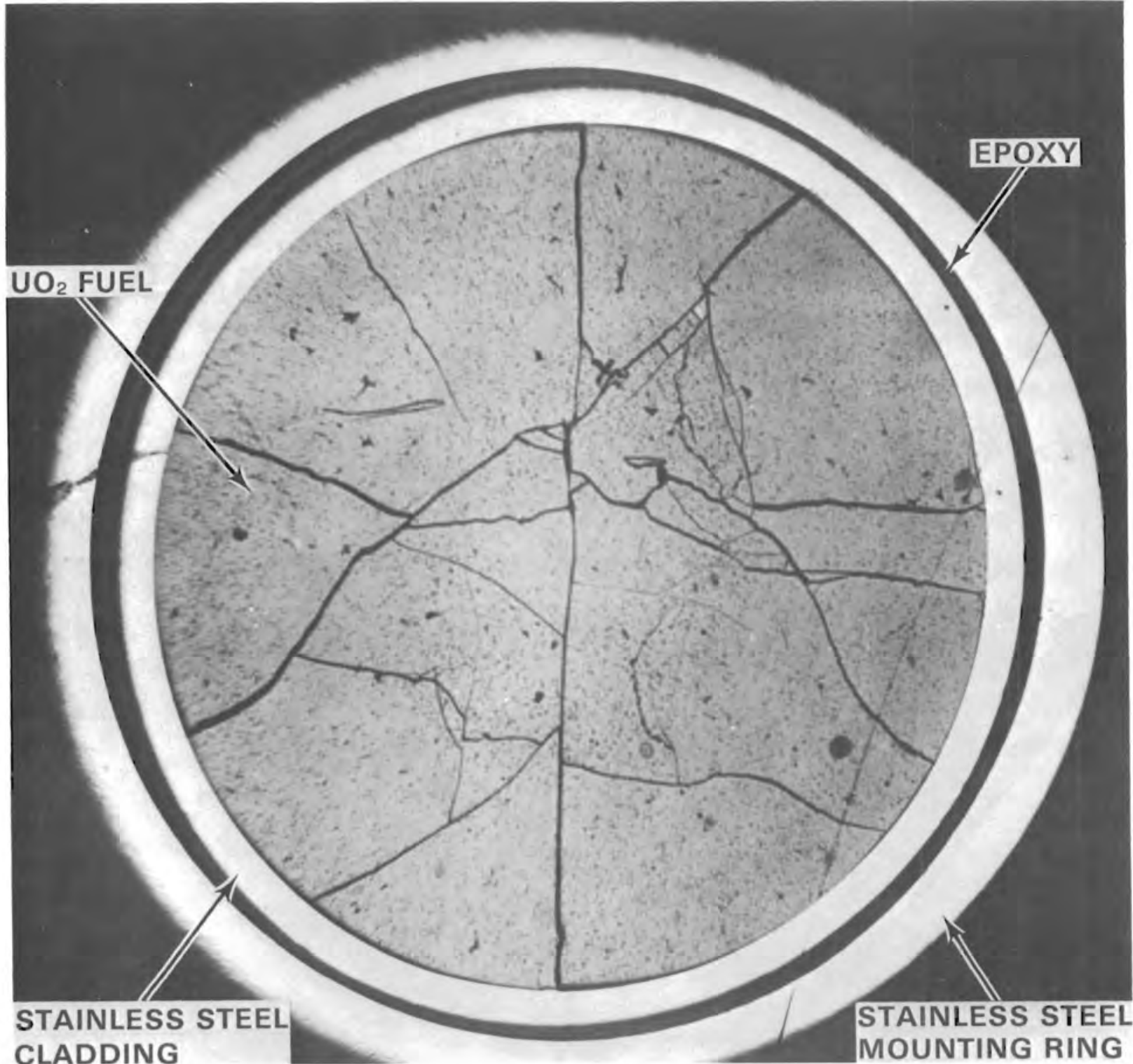

FIGURE 69. Macrograph of the As-Polished Surface from Rod AHR at 56.75 in. $(144 \mathrm{~cm})$ Above the Bottom of the Rod Showing the Structure of the Fuel Seen in the Autoradiographs in Figures 67 and 68

on the cladding surface can increase local temperature and local impurity concentrations in the coolant trapped under or in the crud deposits. The controlled environment in the fuel storage pool is probably the mildest of all the environments that the irradiated fuel assembly encounters. 
The potential for material degradation from environmental effects must be considered. Accordingly, ring crush and tensile tests were conducted to determine postirradiation mechanical properties and deformation behavior of cladding exposed to the normal range of environments.

Cladding specimens for mechanical testing were cut from S004 rod AHR in 1/2-in. $(1.3-\mathrm{cm})$ and $5-\mathrm{in} .(13-\mathrm{cm})$ lengths by a water-cooled abrasive cut-off whee 1 . An attempt to defuel $1 / 2-i n \cdot(1.3-\mathrm{cm})$ long specimens on the fue 1 removal punch press was unsuccessful. The specimens were defueled on a drill rig with an end mill instead of a water-cooled diamond drill. Drilling was slow because much fission gas release was encountered. The retained fisson gas accumulated in unconnected porosity in the fuel and remained there until it was released during drilling (Zimmerman 1975). Very little fission gas moved from the trap sites in the fuel after the fuel was discharged from the reactor, i.e., when the fuel was no longer at the high temperature of reactor operation (Bouffioux and De Meulemeester 1979). Normally this procedure leaves a thin annulus of fuel tightly adhering to the cladding. The annulus is often removed by soaking the sample in nitric acid. We specifically requested that the specimens not be exposed to nitric or any other acid. The $1 / 2-i n .(1.3-\mathrm{cm})$ long specimens were visually examined before testing to ensure that no nicks or scratches were present that could affect test results.

\section{Ring Crush Test}

Side-pressing compression tests (Greenberg and Prager 1951; Johnson 1956; and Sorverby et al. 1968) on 1/2-in. $(1.3-\mathrm{cm})$ long defueled sections of cladding from $\mathrm{SOO} 4$ fuel rods yielded information on the mechanical deformation behavior of the irradiated 304L stainless steel fuel cladding. Test were designed to provide insight into the effects of strain rate or deformation rate and specimen axial location (i.e., local irradiation and thermal environmental histories) on cladding mechanical deformation. A specimen of unirradiated archive material obtained from BNFL was included for comparison.

Specimens were tested on an Instron testing machine, side-pressing the rings in the compression mode. The average of three length measurements was the value used for each of the specimen lengths. Specimen load versus 
displacement and load versus time were recorded. The limits on testing deformation rate were determined by the upper crosshead speed $(2.00 \mathrm{in./min}$ or $5.18 \mathrm{~cm} / \mathrm{min}$ ) and lower crosshead spead $0.002 \mathrm{in.} / \mathrm{min}$ or $0.005 \mathrm{~cm} / \mathrm{min}$ ) of the Instron. An intermediate deformation rate of $0.05 \mathrm{in.} / \mathrm{min}(0.13 \mathrm{~cm} / \mathrm{min})$ was also used. Specimens were selected from low, middle, and high axial rod locations lying within the area of relatively uniform power and burnup (Figures 7 through 9 and Table 28). The rings were loaded until metal-to-metal contact of the ring ID occurred; the cladding did not break or split. Some specimen spring-back occurred after the load was removed. Specimen $3 \mathrm{H}$ did fracture several months after testing while it was being handled for post-test photography in the hot cell. A photographic record of the specimen geometry was being made. No other specimens failed.

Table 28 lists the results of the ring crush tests. Figure 70 shows the strain-rate dependence of the collapse load (Pc) normalized for specimen length. Figure 71 shows the strain-rate dependence of the strain (i.e., crosshead displacement) at ring collapse. A correlation of the axial location of the specimen with deformation behavior is apparent in the strain-rate plots. Specimen $3 \mathrm{~F}$ may be an anomaly (it was the first test in the series).

The general conclusion is that the irradiated cladding is not brittle under compressive loading (less than $1 \%$ uniform elongation). The mechanical deformation behavior in the ring crush tests is similar to that of archive material under these testing conditions.

The link between the crush test and conventional tensile test is the collapse load. Rosenfield (1978) developed a correlation between collapse load $(P C)$ and flow stress $\left(\sigma_{f}\right)$. Figure 72 shows a schematic load versus displacement plot for a ring. The point $P_{C}$ is the collapse load and is determined by extrapolating the lines from the two linear regions. The flow stress is described as the average of the $0.2 \%$ offset (YS) and the ultimate tensile strength (UTS). Figure 73 shows the correlation developed by Rosenfield between the normalized collapse load and the ratio of the inside diameter (Di) to the outside diameter (Do) of the ring. Rosenfield's investigation included rings with (Di/Do) values in the range of 0.25 to 0.75 . The (Di/Do) of the rings tested in this program was 0.92 . 
TABLE 28. Side-Pressing Ring Crush Test Results (a)

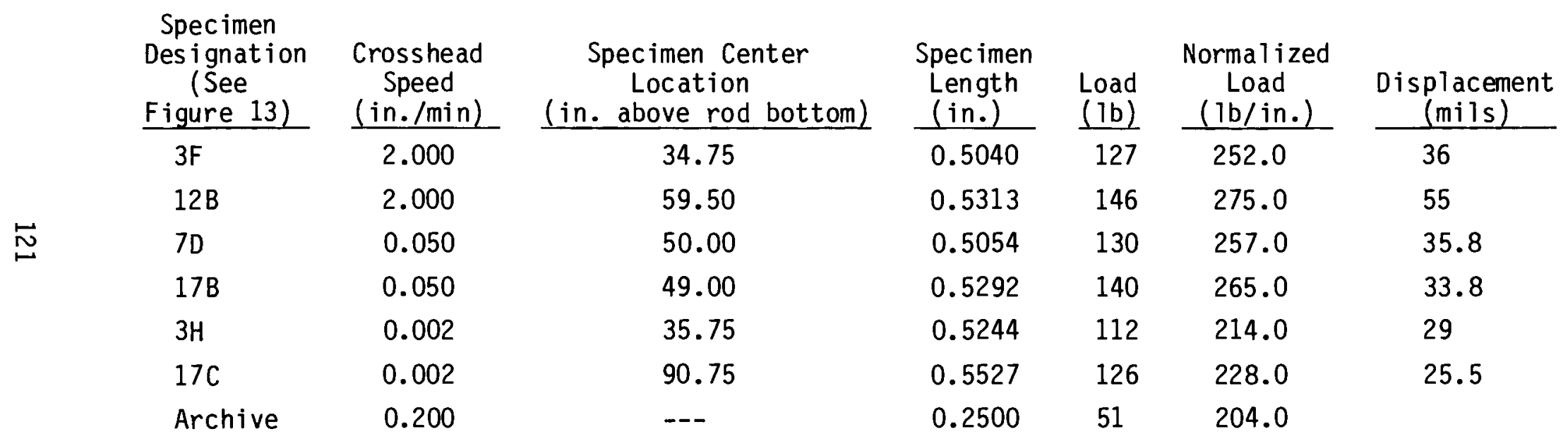

(a) Fuel cladding from assembly S004. Cladding material is 304L SS drawn-welded tubing, nominally $12 \%$ cold-worked. Nominal cladding 00 is $10.76 \mathrm{~mm}(0.4235 \mathrm{in}$.); wall thickness is $0.42 \mathrm{~mm}(0.0165 \mathrm{in.})$. 


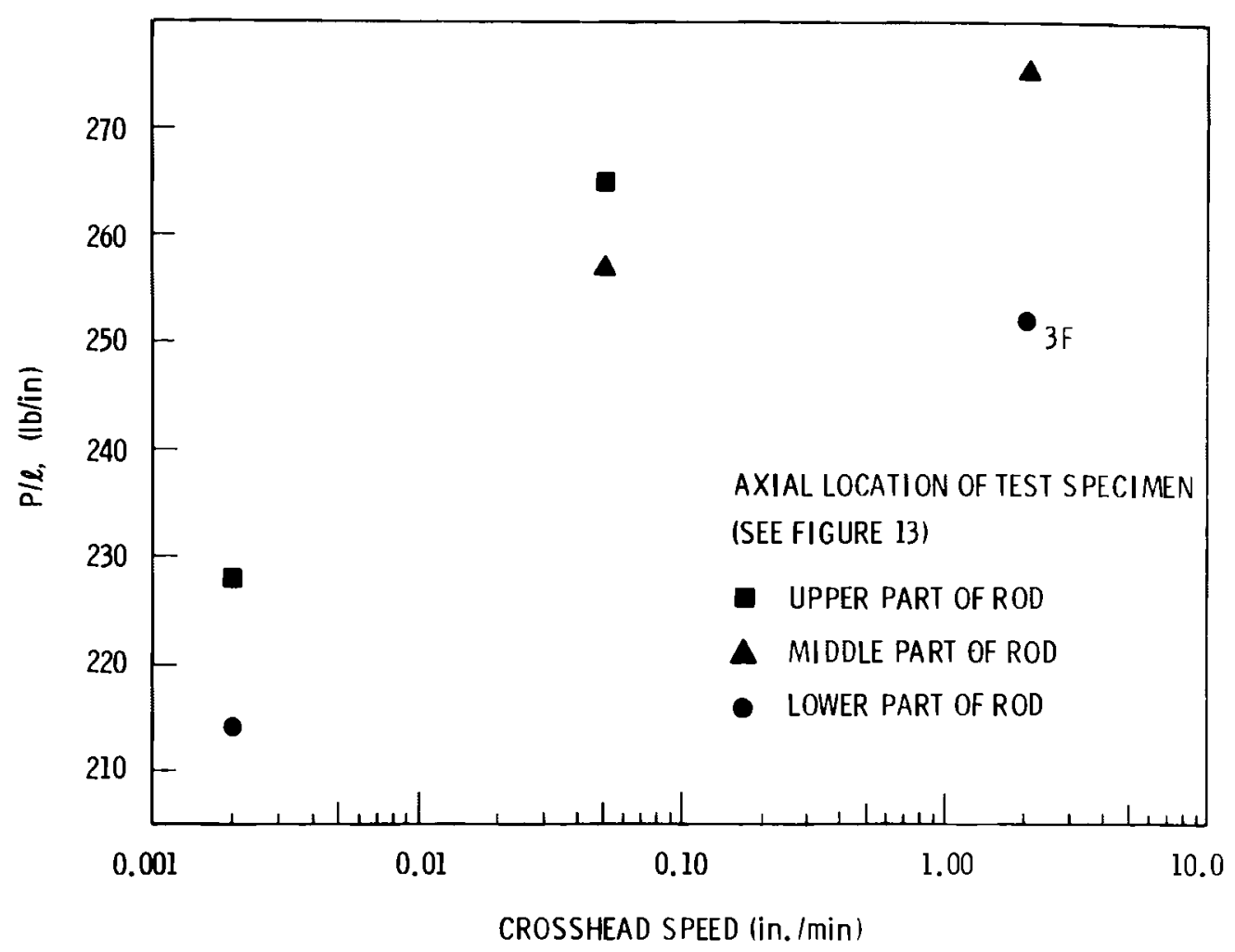

FIGURE 70. Results of Side-Pressing Crush Tests of Rings of Irradiated 304L Stainless Steel Cladding Showing the Dependence of Collapse Load on Deformation Rate. The collapse load, Pc, has been normalized for specimen length, $\ell(250 \mathrm{lb} / \mathrm{in} .=$ $44.6 \mathrm{~kg} / \mathrm{cm} ; 1.00 \mathrm{in.} / \mathrm{min}=2.54 \mathrm{~cm} / \mathrm{min}$ )

The normalized collapse load is $\mathrm{Pc} / \mathrm{\sigma}_{\mathrm{f}}$ Dol, where $\mathrm{Pc}=$ collapse load, $\sigma_{f}=$ flow stress, Do $=$ outside diameter of ring, $\ell=$ length of ring. Table 29 lists the values of normalized collapse loads calculated for the ring crush tests. The average of these values constitutes a reasonable extrapolation of Rosenfield's results. The agreement with Rosenfield's results and the consistency of the tests themselves support the results of the ring crush tests as being representative of the mechanical deformation behavior of cladding.

\section{$\underline{\text { Tensile Test }}$}

Tensile tests on 5 -in. $(13-\mathrm{cm})$ long defueled sections of irradiated Type 304L stainless steel cladding from $\mathrm{SO04}$ fuel rods yielded information on the mechanical strength and ductility during uniform mechanical deformation. 


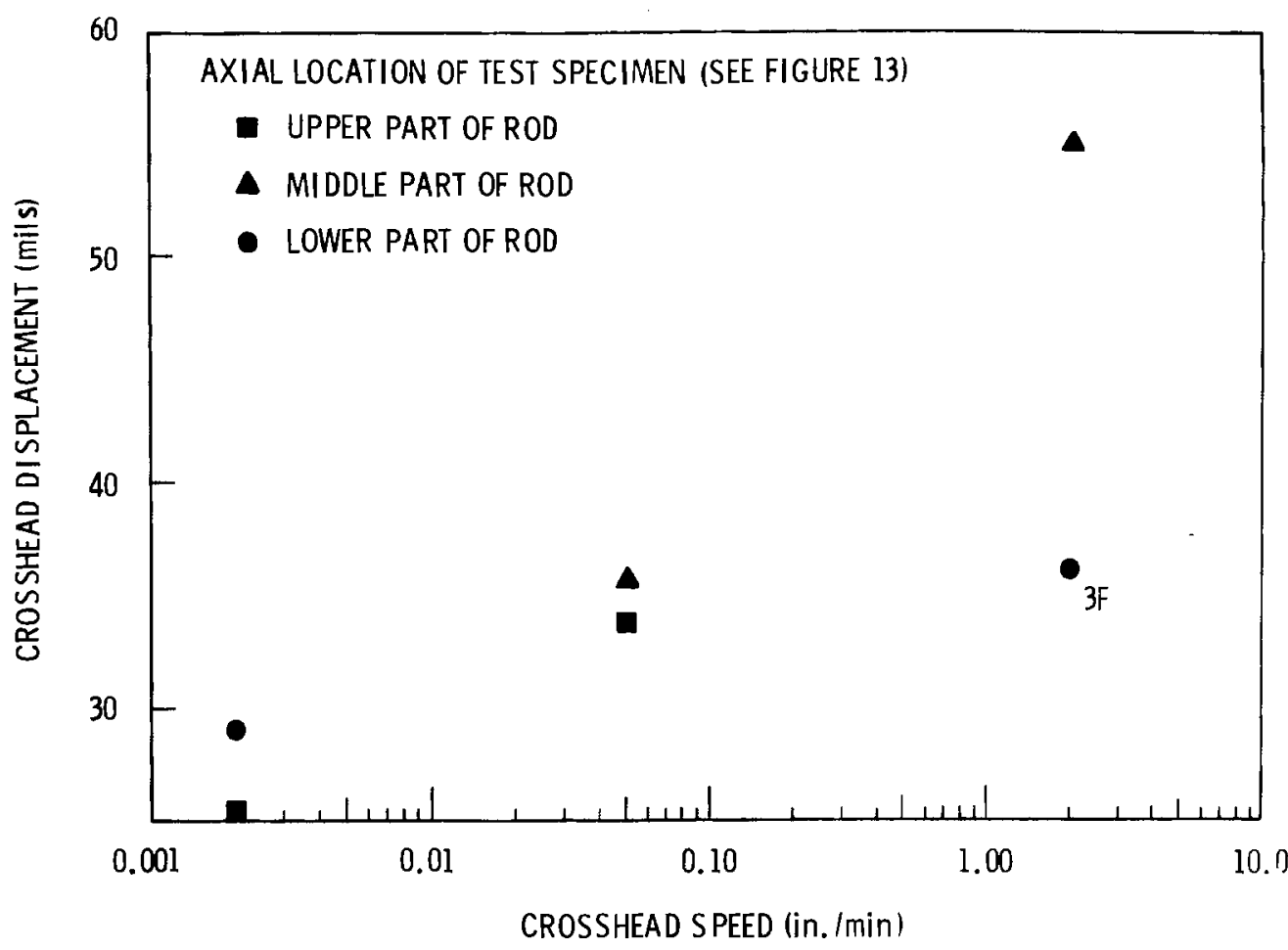

FIGURE 71. Collapse Deformation Versus Deformation Rate from Ring Crush Tests on Irradiated 304L Stainless Steel Showing the Dependence of Deformation at Collapse on Deformation Rate $(50 \mathrm{mils}=1.27 \mathrm{~mm} ; 1.00 \mathrm{in} . / \mathrm{min}=2.54 \mathrm{~cm} / \mathrm{min})$

Deformation was continued until specimen fracture occurred. A test matrix similar to that developed for the ring crush tests provided insight into the effects of strain rate or deformation rate and specimen axial location (i.e., local irradiation and thermal environmental histories) on cladding strength and ductility during uniform deformation.

Again, specimens were tested on an Instron testing machine. To support the specimen ends gripped in the Instron, $11 / 2-i n .(3.8-\mathrm{cm})$ long plugs were prepared; one was inserted into each end of the specimen. Axial strain of the $2-i n .(5 \mathrm{~cm})$ gage length was measured with a clip gage. Specimen load versus displacement, as well as load versus time behavior, was recorded. Nominal as-fabricated cladding dimensions were used to compute the stresses. 


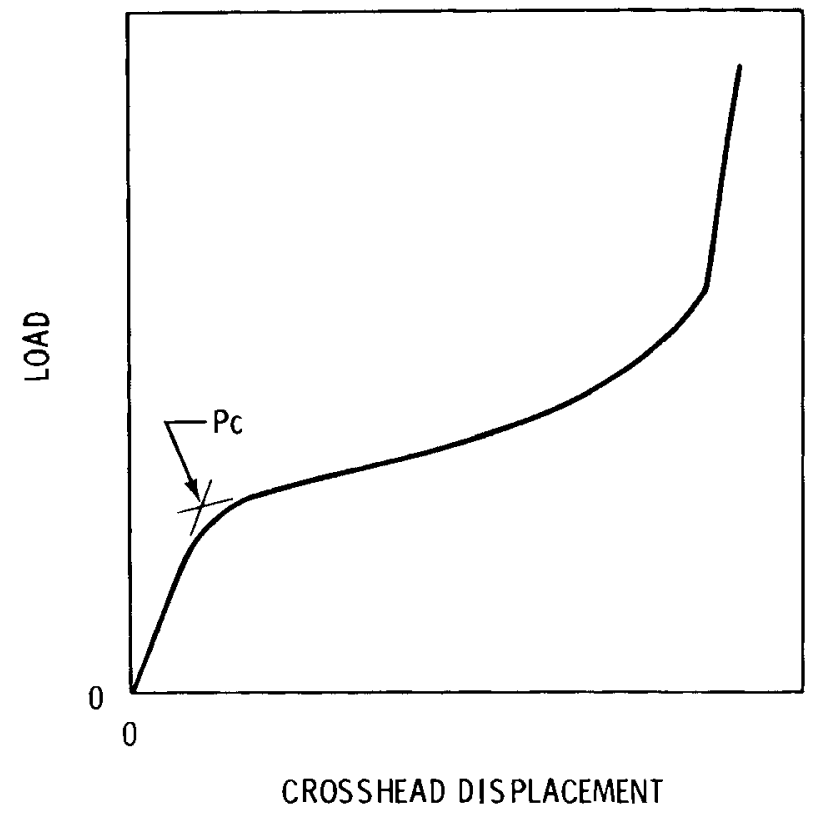

FIGURE 72. Schematic Load Versus Displacement Curve for Side-Pressing Ring Crush Test

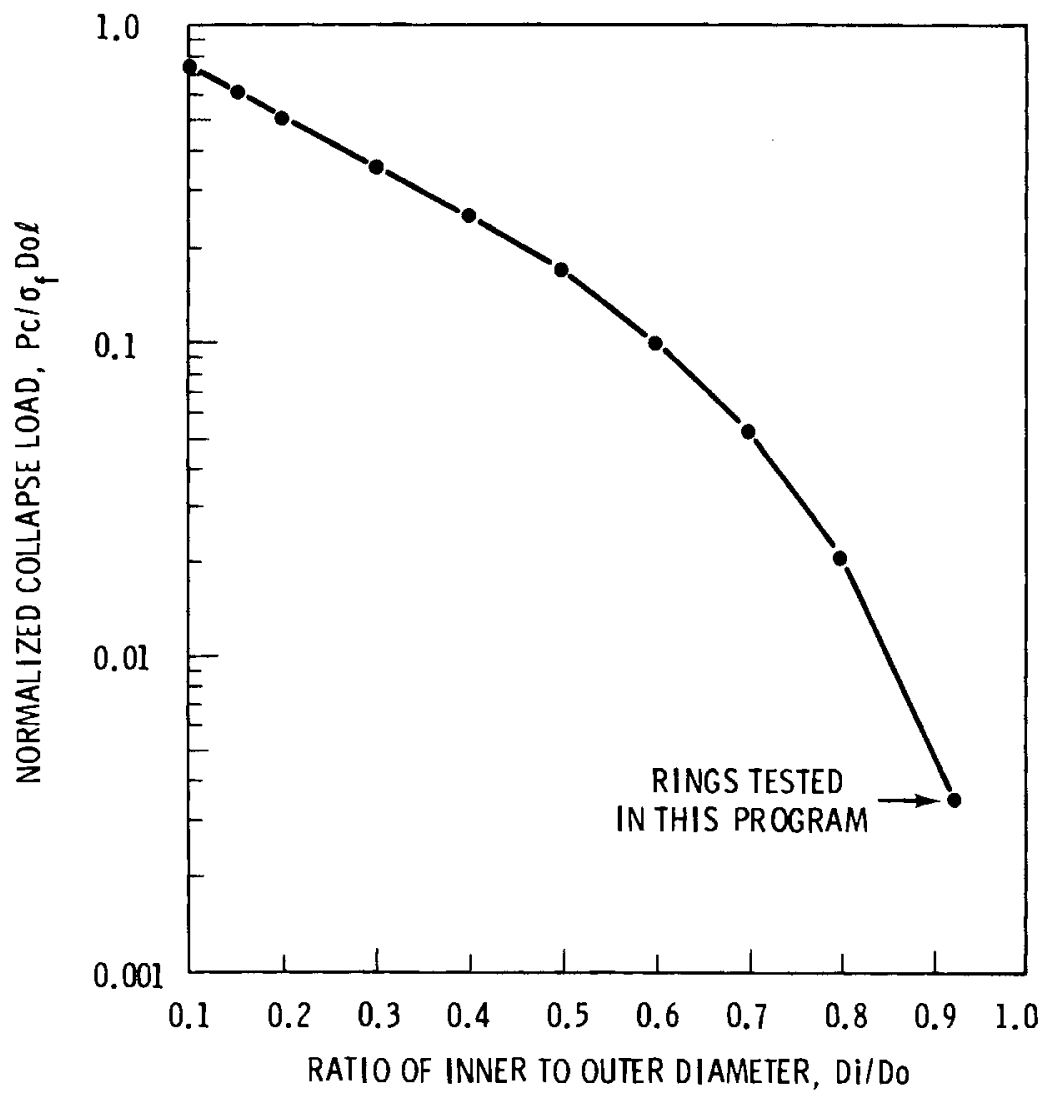

FIGURE 73. Dependence of Collapse Load on Ring Geometry in the Side-Pressing Ring Crush Test 
TABLE 29. Normalized Collapse Loads for Ring Crush Tests of Cladding from S004 Rod AHR

\begin{tabular}{|c|c|c|c|c|}
\hline Spec imen & $\begin{array}{l}\text { Collapse } \\
\text { Load (1b) }\end{array}$ & $\begin{array}{l}\text { Length } \\
\text { of Ring } \\
\text { (in.) } \\
\end{array}$ & $\begin{array}{c}\text { Flow } \\
\text { Stress (a) } \\
(\text { psi) } \\
\end{array}$ & $\begin{array}{c}\text { Normal ized } \\
\text { Collapse } \\
\text { Load }\end{array}$ \\
\hline $3 F$ & 127 & 0.5040 & 171,848 & $3.46 \times 10^{-3}$ \\
\hline $12 B$ & 146 & 0.5313 & 169,787 & $3.82 \times 10^{-3}$ \\
\hline 70 & 130 & 0.5054 & 167,180 . & $3.63 \times 10^{-3}$ \\
\hline $17 \mathrm{~B}$ & 140 & 0.5292 & 164,337 & $3.80 \times 10^{-3}$ \\
\hline $3 \mathrm{H}$ & 112 & 0.5244 & 166,825 & $3.02 \times 10^{-3}$ \\
\hline $17 \mathrm{C}$ & 126 & 0.5527 & $\begin{array}{l}160,308 . \\
\text { AVERAGE }\end{array}$ & $\begin{array}{l}3.36 \times 10^{-3} \\
3.52 \times 10^{-3}\end{array}$ \\
\hline
\end{tabular}

(a) The flow stress, $\sigma_{f}=1 / 2($ UTS $+Y S)$, is calculated from the tensile test results (see Table 30). UTS is the ultimate tensile strength and YS is the yield stress.

Table 30 lists the results of the longitudinal tensile tests on six specimens. Figure 74 shows the low strain-rate dependence of the yield strength ( $0.2 \%$ offset). Figure 75 shows the strain-rate dependence of the difference between the ultimate tensile strength (UTS) and the yield strength (YS). Figure 76 illustrates the strain-rate dependence of the cladding uniform elongation. Ultimate tensile and yield strengths showed some correlation with the axial location of the specimen. There was no consistent variation of uniform elongation with axial location.

The tensile strength of the irradiated cladding has increased and the elongation has decreased significantiy compared to the nominal values for unirradiated samples of other comparable Type 304 stainless steel cladding used in other Connecticut Yankee fuel assemblies. However, the irradiated cladding retained sufficient ductility to withstand crushing without breaking or splitting. Only six irradiated specimens were tested and the results for total elongation varied over quite a range. The single tensile specimen that broke in the center of the specimen gage length had a total elongation of $20 \%$. The other five speciments exhibited less total elongation (1.7 to 6.0\%) but similar uniform elongations (1.1 to $1.6 \%$ ). Similar but unirradiated cladding exhibits an elongation of $46 \%$. 
TABLE 30. Tensile Test Results(a)

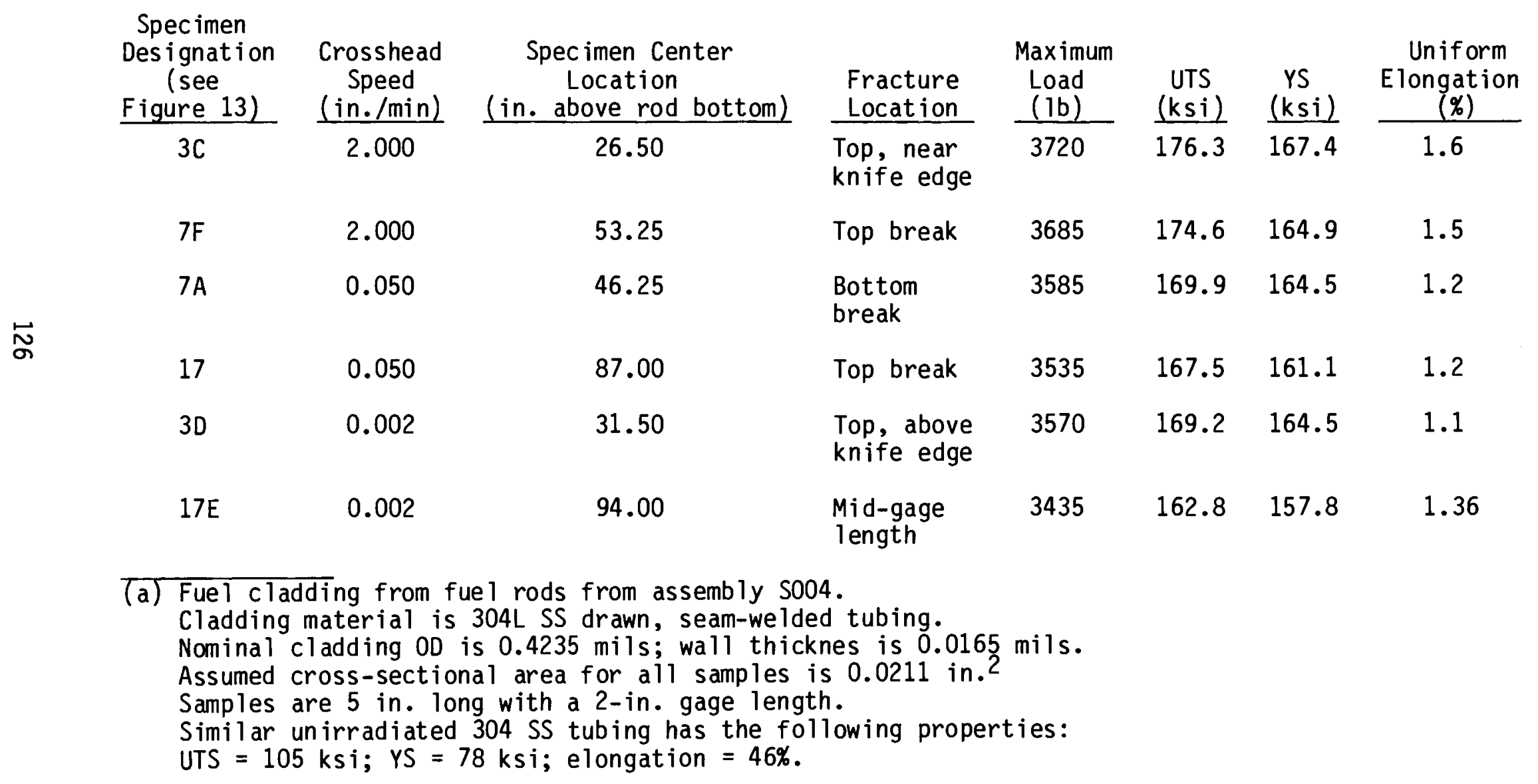




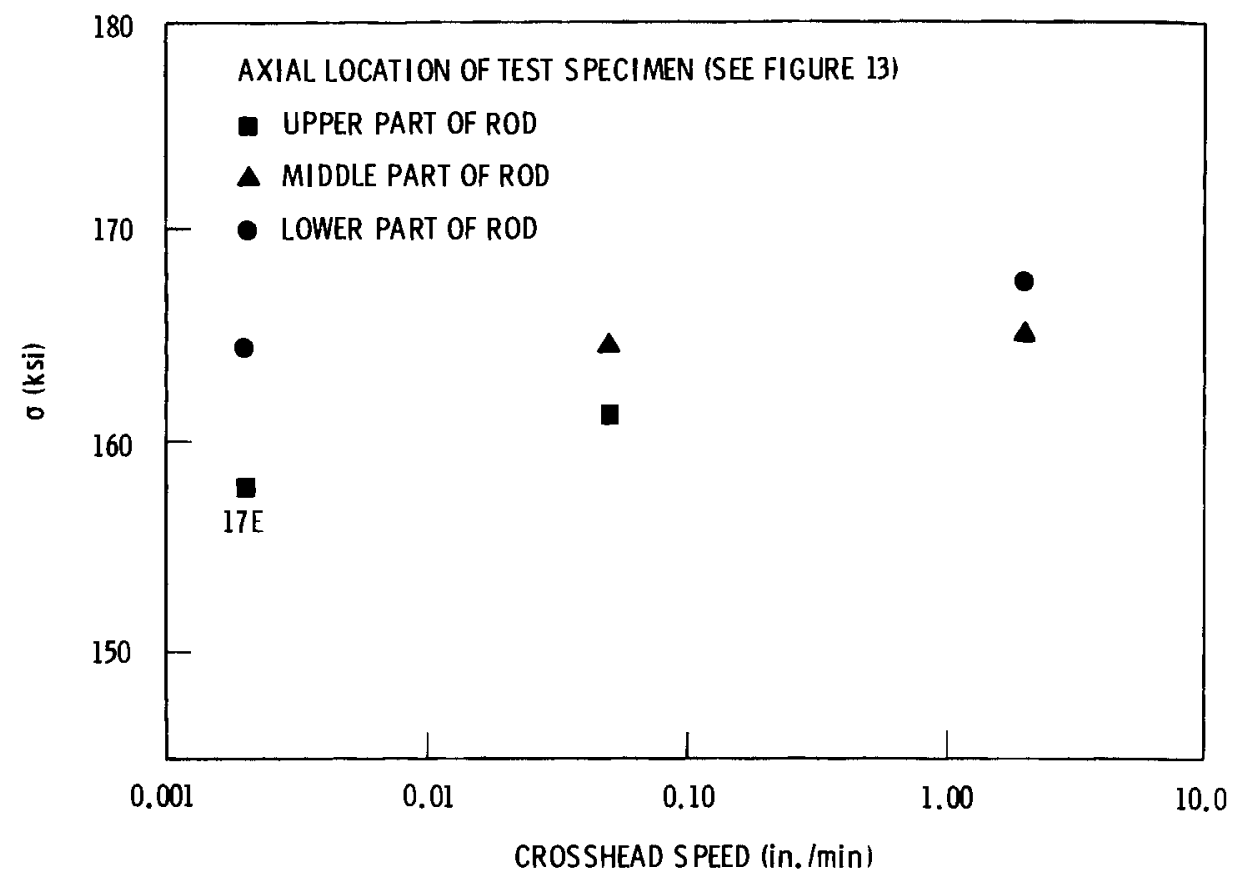

FIGURE 74. Cladding Tensile Test Results for Irradiated 304L Stainless Steel Showing the Low Strain-Rate Dependence of the Yield Strength, $\sigma$ (0.2\% 0ffset), $(160 \mathrm{ksi}=1100 \mathrm{MPa} ; 1.00 \mathrm{in} . / \mathrm{min}=2.54 \mathrm{~cm} / \mathrm{min})$

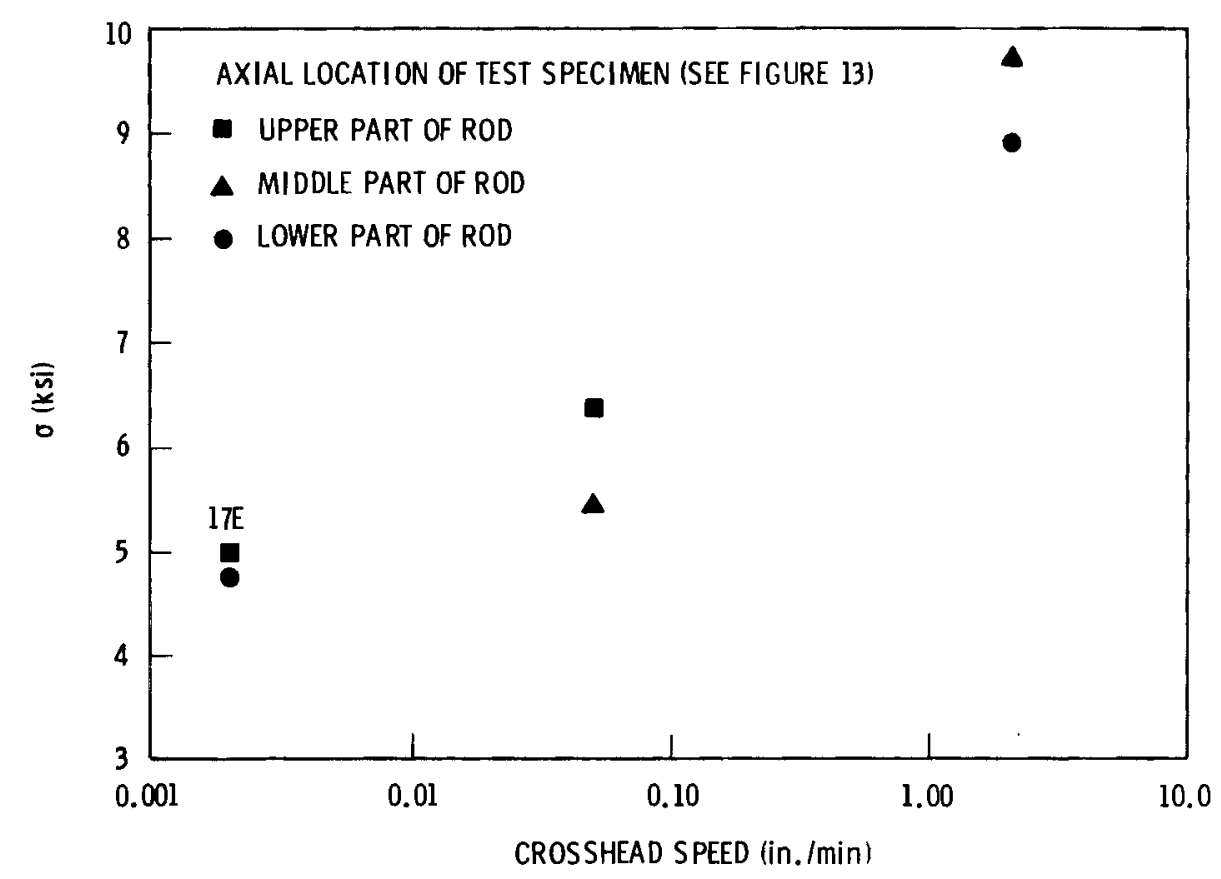

FIGURE 75. Cladding Tensile Test Results Showing the Strain-Rate Dependence of the Difference Between the Ultimate Tensile and Yield Strengths for Irradiated 304L Stainless Steel (6 ksi $=41 \mathrm{MPa}$; $1.00 \mathrm{in.} / \mathrm{min}=2.54 \mathrm{~cm} /$ in.) 


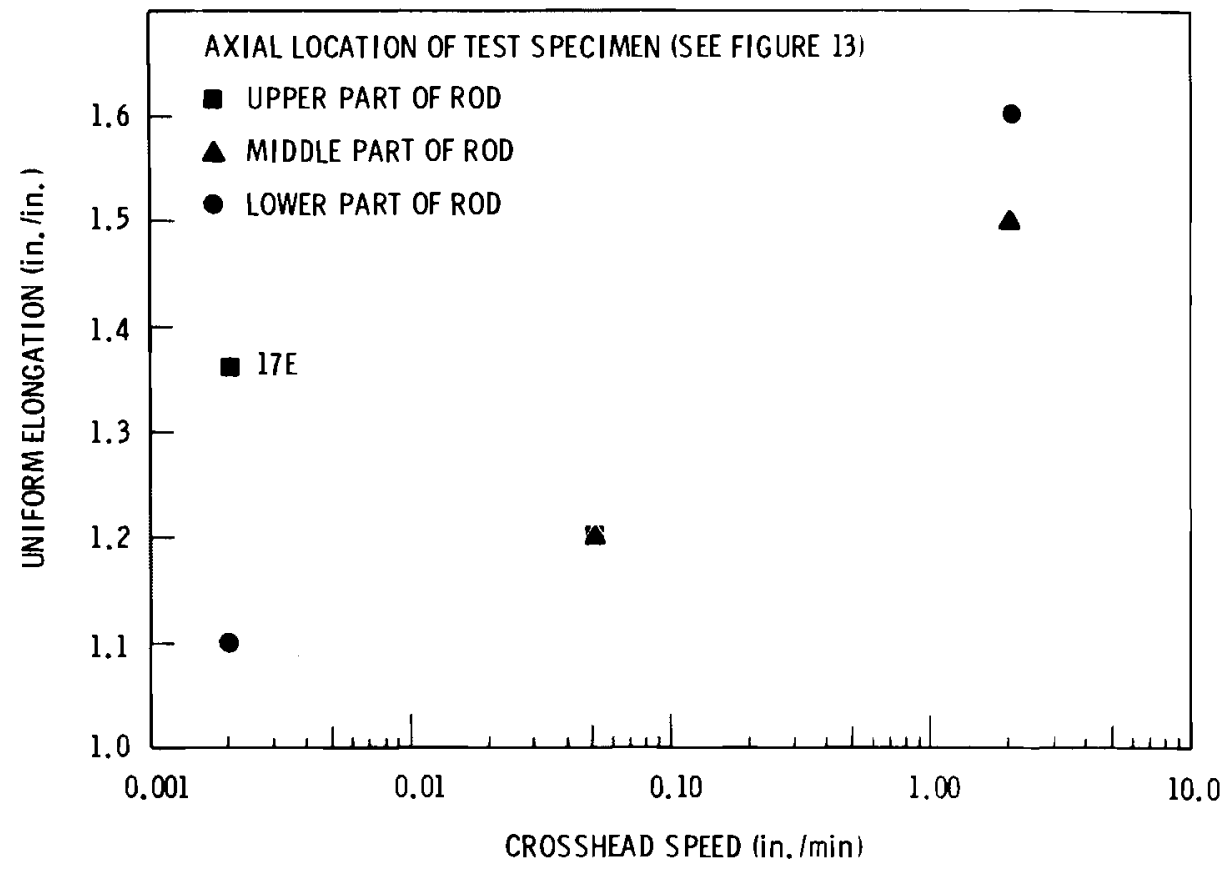

FIGURE 76. Cladding Tensile Test Results Showing the Dependence of Strain-Rate on the Specimen Uniform Elongation for Irradiated $304 \mathrm{~L}$ Stainless Stee $1(1.00 \mathrm{in.} / \mathrm{min}=$ $2.54 \mathrm{~cm} / \mathrm{min}$ ) 


\section{REFERENCES}

Anderson, P. A., and H. S. Meyer. 1980. Dry Storage of Spent Nuclear Fuel. NUREG/CR-1223. U.S. Nuc lear Regulatory Commission, Washington, DC.

Barney, W. K., and B. D. Wemp le. 1958. Metallography of Irradiated $\mathrm{UO}_{2}$-Conta ining Fue 1 Elements. KAPL-1836, Kno11s Atomic Power Laboratory, Schenectady, New York.

Bouffioux, P. and E. De Meulemeester. 1979. "Prediction of Fission Gas Release at High Burnup." Proceedings of the ANS Topical Meeting on Light Water Reactor Fue 1 Performance, Portland, Oregon.

Carter, W. L. 1980. Spent Fuel and Waste Inventories and Projections. OR0-778, Oak Ridge National Laboratory, Oak Ridge, Tennessee.

Fuhrman, N. et a1. 1976. Evaluation of Fuel Rod Performance in Maine Yankee Core 1. EPRI NP-218, Electric Power Research Institute, Palo Alto, California.

Garzarolli, F., D. Jorde, R. Manzel, G. W. Parry, and P. G. Smerd. 1980. Review of PWR Fuel Rod Waterside Corrosion Behavior. EPRI NP-1472. Prepared by Kraftwerk Union AG, F.R.G. and Combustion Engineering, Inc., Windsor, Connecticut, pp. 3-15 and 4-5.

Garzarolli, F. and R. Manzel. 1979. "High Burnup Performance in LWRs." Trans. Am. Nuclear Soc. 31:162-163.

Giacobbe, F. S. 1981. "Examination, Evaluation, and Repairs of Stress Corrosion Cracking in a PWR Borated Water Piping System." Corrosion 81, Toronto, Ontario, Canada.

Greenberg, H. J. and W. Prager. 1951. "Limit Design of Beams and Frames." Proc Am. Soc. Civil Eng. 77(59):1.

Hea 1, T. J., J. E. Littlechild, and H. Page. 1980. "Fuel Production-An Advanced Technology. Nuclear Engineering International, pp. 48-51.

Johnson, A. B., Jr. 1975. "A Review of Corrosion Phenomena on Zirconium Alloys, Niobium, Titanium, Inconel, Stainless Steel, and Nickel Plate Under Irradiation." Reviews on Coatings and Corrosion. J. Yahalom (ed.), Freund Pub 1. House, Tel Aviv, Israel, pp. 352-356.

Johnson, A. B., Jr. et al. 1980. Annual Report - FY-1979, Spent Fuel and Fuel and Fuel Pool Component Integrity. PNL-3171, Pac if ic Northwest Laboratory, Rich land, Washington.

Johnson, A. B., Jr., E. R. Gilbert, and R. J. Guenther. 1982. Behavior of Spent Nuclear Fue 1 and Storage System Components in Dry Inter im Storage. PNL-4189, Pac if ic Northwest Laboratory, Richland, Washington. 
Johnson, W. 1956. "The Compression of Circular Rings." J. Royal Aero. Soc. $60: 484$.

Klingensmith, R. W. 1980. "Airborne Contamination Released During Underwater Unloading of Failed PWR Spent Fuel Assembly." Proceedings-PATRAM 80.

Littlechild, J. E. and G. G. Butler. 1976. "The Specification and Quality Control of $\mathrm{UO}_{2}$ Fuel Pellet Microstructure to Ensure Density Stability and Low Mo isture Content." Proceedings of Seminar on Nuclear Fuel Quality Assurance. International Atomic Energy Agency.

Multer, I. 1975. "European Operating Experience," a paper presented at the Joint Topical Meeting on Commercial Nuc lear Fuel Technology Today, held in Toronto, Ontario, Canada, April 1975.

Northern States Power Company. 1982. Licensee Event Report No. 81-031/01X-1, Docket No. 50-282 (Prairie Island-1).

Pasupathi, V. and R. W. Klingensmith. 1981. Investigation of Stainless Steel Clad Fuel Rod Failures and Fuel Performance in the Connecticut Yankee Reactor. EPRI NP-2119, Electric Power Research Institute, Palo Alto, California.

Phillips, J. R. et al. 1980. Application of Nondestructive Gamma-ray and Neutron Techniques for Safeguarding of Irradiated Fuel Materials. LA-8212. Los Alamos Scientific Laboratory, Los Alamos, New Mexico.

Raven, L.F.A. 1976. "The Performance of BNFL Controlled Porosity Nuclear Fue 1," Paper No. 45-N-76 presented at the 78th Annual Meeting of the American Ceramic Society, held in Cincinnati, Ohio, May 1976.

Rosenbaum, H. S., J. S. Armijo, and U. E. Wolf. 1966. Fission Fragment Damage to 304 SS Fuel Cladding. GEAP-5002, General Electric Company, San Jose, California.

Rosenfield, A. R. 1978. "Diametral Compression of Rings." Strain 14(4):150.

Sorverby, R., W. Johnson and S. K. Samanta. 1968. "The Diametrical Compression of Circular Rings by 'Point' Loads." Int. J. Mech. Sci. 10:369.

Storev, J., and D. H. Locke. 1970. "High Burnup Irradiation Experience in Vulcain." Nuclear Eng ineering International. February 1970, pp. 93-99.

Zhou, S. Y., and D. R. 01 ander. 1981. "Thermal Gradient Redistribution of Ruthenium in $\mathrm{UO}_{2}$." Trans. Am. Nuc 1. Soc. 38:314-315.

Zimmerman, H. 1975. "Fission Gas Behavior in Oxide Fuel Elements of Fast Breeder Reactors." Nuclear Technology 28:127-133. 